

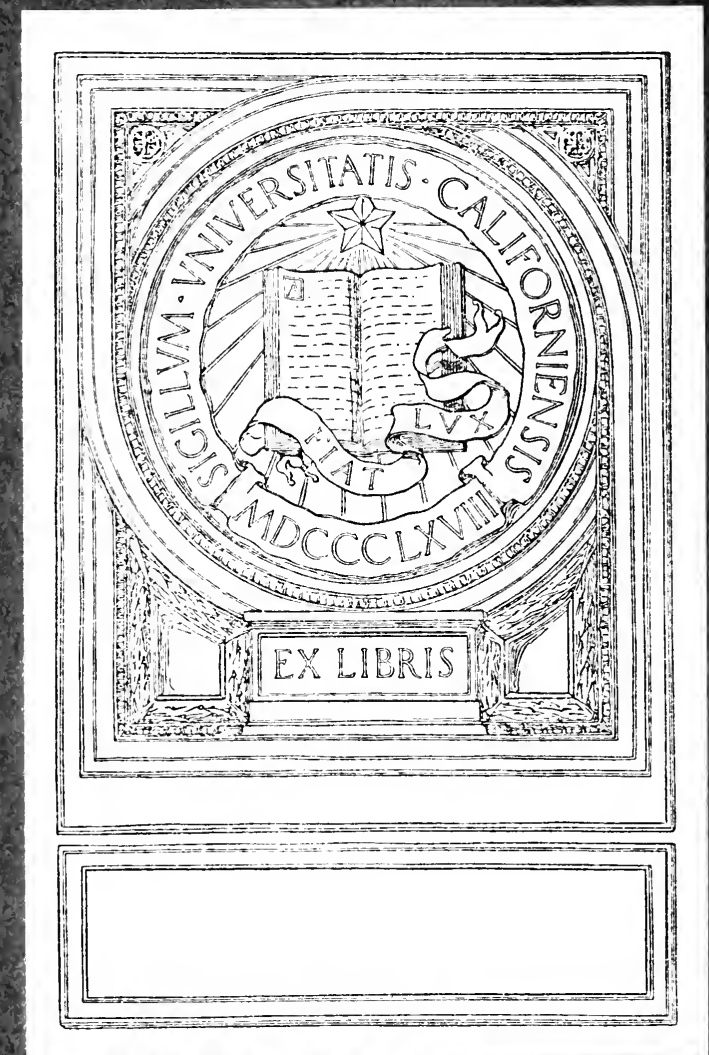


Digitized by the Internet Archive in 2007 with funding from Microsoft Corporation 


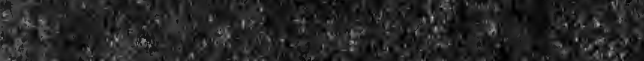

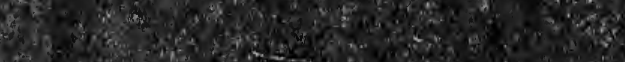

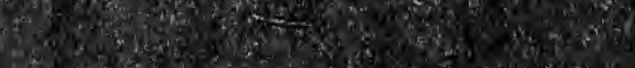

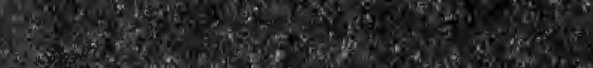
2.

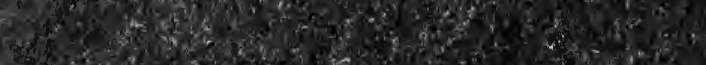

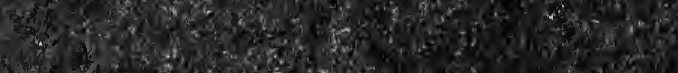
SW.

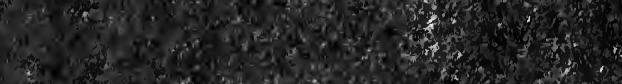

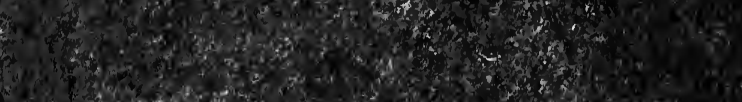
S. (1)

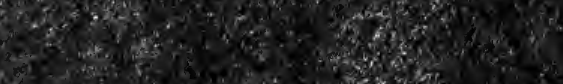

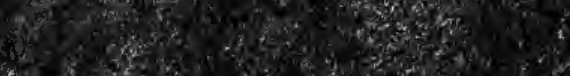

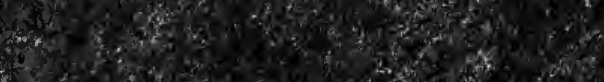

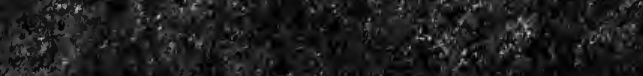

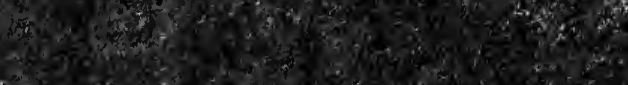

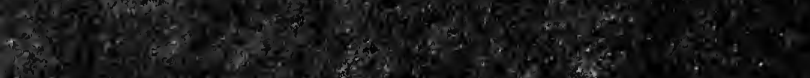

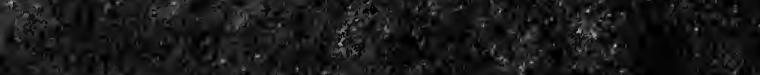

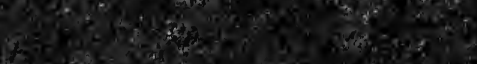

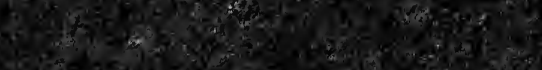




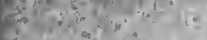

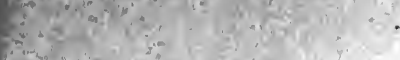

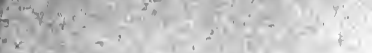

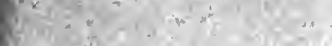

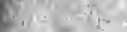

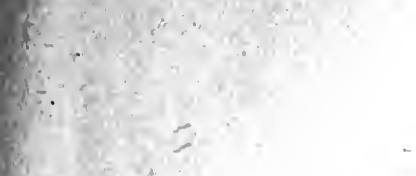

$$
\text { . }
$$




$$
+
$$




\title{
AT THE COURT
}

\author{
of \\ HIS CATHOLIC MAJESTY
}




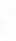




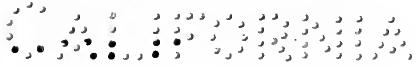


$\because \because \vdots \quad \because \because \vdots \vdots \vdots \vdots \vdots \vdots \vdots \vdots 0$

$\therefore \vdots \vdots \because \because \because \because \cdots \vdots \vdots \vdots \cdots \cdots$

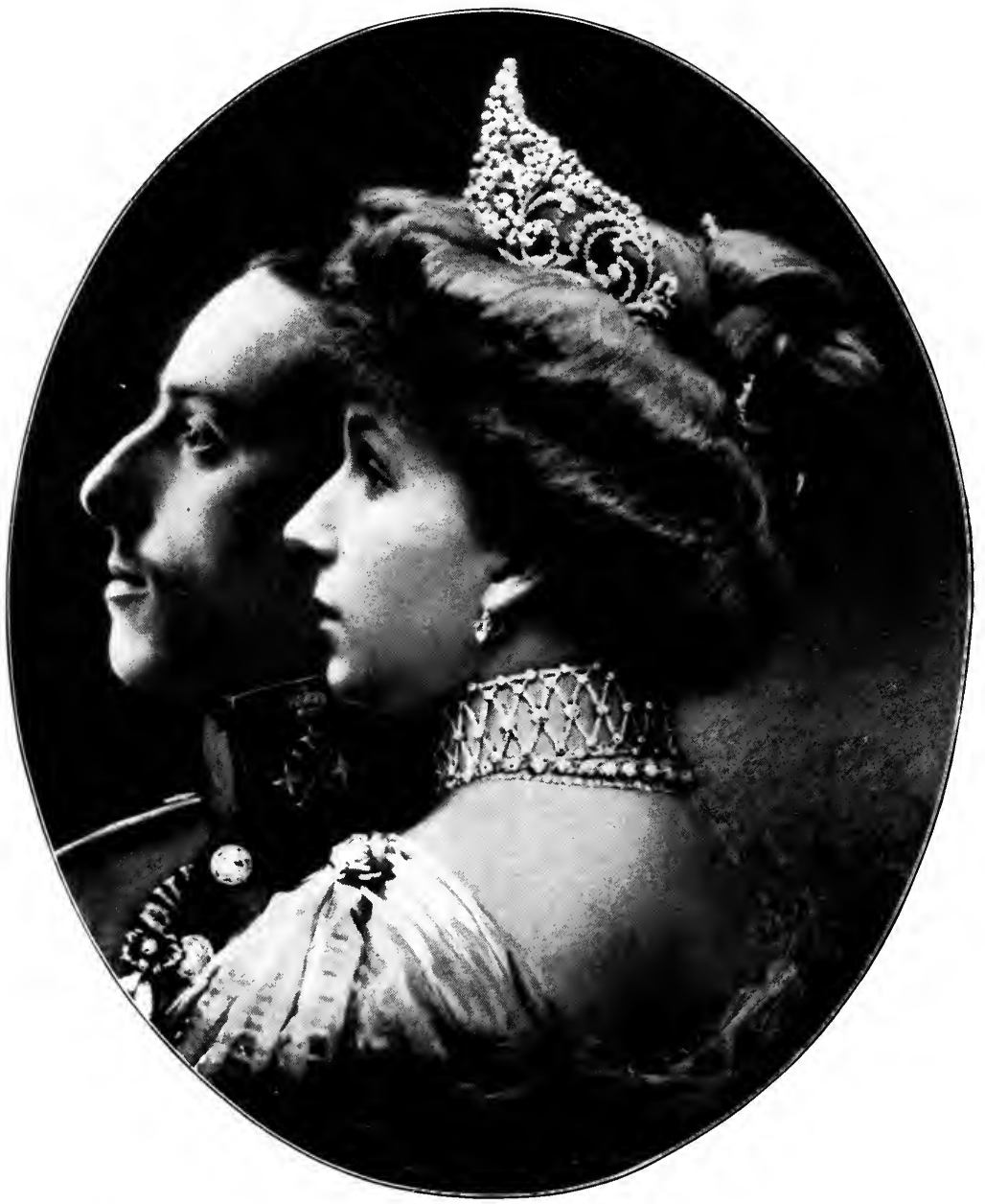

Photo by Kaulak

Frontispiece

Their Majesties, the King and Queen of Spain 


\section{-AT THE COURT \\ OF \\ HIS CATHOLIC MAJESTY •}

BY

WILLIAM MILLER COLLIER

LATE AMERICAN MINISTER TO SPAIN

WITH ILLUSTRATIONS

FROM PHOTOGRAPHS

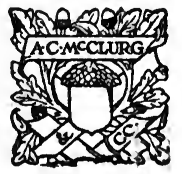

CHICAGO

A. C. McCLURG \& CO.

I9I 2 
c 6

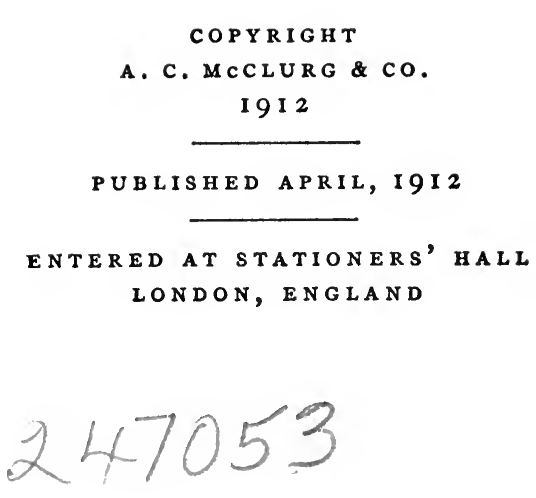

$\because \quad \because$

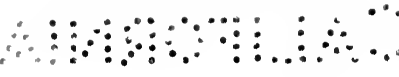

THE.PLIMPTON.PRESS
[W.D.O] ]
NORWOOD.MASS.U.S.A 
TO MY WIFE

FRANCES BEARDSLEY COLLIER

WHO SHARED WITH ME THE HAPPINESS OF MY LIFE "AT THE COURT OF HIS CATHOLIC MAJESTY" AND WHO DID SO MUCH TO CONTRIBUTE tO IT, AND WHO NOT ONLY HAS INSPIRED THE WRITING OF THIS BOOK, BUT HAS GREATLY AIDED ME IN THE COLLECTION AND PRESERVATION OF MATERIAL FOR IT, I AFFECTIONATELY DEDICATE IT 



\section{PREFACE}

HE life of a diplomat is as busy as it is varied. Unfortunately for him much of his work, - patient, persistent, silent negatiation and tactful, thoughtful, personal representation, - must be done without publicity, and the masses, seeing him principally as a participant in the ceremonies of the court or in the activities of society, often regard him as a mere idler. Custom has, indeed, fixed for him many social duties, as well in relation to the court to which he is accredited and the people of the country to which he is sent as to his own compatriots who may visit it. These duties unquestionably occupy much of his time, and upon the manner of their discharge depends in no small measure his success or his failure.

In my four years' residence as American Minister at Madrid, many questions of importance arose and were settled; many matters of concern to the business interests of the two countries were adjusted to the mutual advantage of Spain and the United States; and above and beyond all, there was the constant endeavor to demonstrate the strength and sincerity of the good-will of the Government and people of the United States for 
that historic nation whose great Queen Isabella, alone of all the sovereigns of Europe, had the courage and the faith and the philanthropy to aid the oft rejected and much ridiculed Genoese navigator and to make possible that voyage which ended in giving a New World not only to Castile and Leon, but to all humanity.

In the performance of my duties I learned more and more to esteem Spanish character. My work brought me into intimate relations with Spain's statesmen who directed her foreign policy and gave me as the representative of a sovereign nation many an audience with the King and the Queen and the other members of the royal family.

Since my return from Spain I have of ten been urged to write something about my life there, and as I have now done so, it is but fair to the reader that he should know the limitations that I have felt obliged to put upon my book. It would no doubt be interesting to many if I were to tell of some of the things that were talked over in those audiences with the members of the royal family, and if I were to reveal something of their personal character and family life; but all must appreciate that what is said at such times to those who bear the official relation that I did to them should be treated as confidences, even though no injunction of secrecy is laid. There may be some who think that far more instruction and profit could be derived from a study of modern political and social conditions in Spain. I will not take issue with them; but this book is not for them. 
Moreover the reader must not expect to find herein a description of any of the numerous glorious epochs in the history of this ever heroic nation. I know how full of interest such a book might be. For Spain is a land whose history has been real, - vitally real, sometimes terribly real. And over it all there is cast the glamour of romance; it charms and fascinates while it thrills and excites and teaches and warns. Who can help admiring that people who in ancient days gave to Rome's all-conquering legions their most stubborn resistance, and who at Numantia died, to a man, rather than surrender? Who can resist the plaintive melody of the Song of Roland, which chants eternally the requiem of Charlemagne's great paladin, defeated in the Pass of Roncesvalles by the Spanish Basques? Is it possible anywhere to find a nobler example of the fortitude, perseverance, and constancy of a race than that of the Spaniards who, after having been hurled back to the mountain fastnesses of the North by the wave of Mohammedan invasion that swept over Europe, emerged from their caves of refuge and, year after year, for seven long centuries, waged ceaseless warfare until at Granada they captured the Moslem's last stronghold and saved the world to Christianity? And what faith in the imperishability of this nation must everyone have who recalls how, when their kings had faltered and failed, and when the invader by treachery had entered their country and placed his brother upon its throne, this people, kingless and almost leaderless, with indomitable spirit, aided by their 
English allies, beat back the armies of Napoleon which had marched in conquering triumph over the whole continent, hastened his downfall, and saved all Europe from being subjected to the will and the power of one man? But many persons have already written erudite and profound histories of these great events; and although much may still remain for historical investigation, nevertheless to write faithfully and worthily and accurately requires more time for careful research, critical study, and calm reflection than I have had at my disposal. It is, therefore, of that which I myself have seen and in which I myself took part that I have written.

The years of my residence in Madrid, 19051909, were characterized in a marked degree by events of unusual interest in the life of the royal family and the court. In this period occurred the marriage of the King's younger sister, of the King himself, and the birth of the heir to the throne, and of several other children to Their Majesties; cardinals received in Madrid, at the hands of the King, the insignia of their high rank; sovereigns made state visits to King Alfonso; princes, many of them to-day monarchs seated on thrones, came to Spain from all the courts of the world. Stately ceremonies attended all these events. Grand pageants were connected with not a few of them. There was movement, color. An active social life was revived at the court. It was modern, yet to no small 'extent it was clothed in mediæval garb; for the ceremonies were those that precedent prescribed and tradi- 
tion handed down. The new was modelled on the old. The Past lived in the Present. The pageants were panoramas of the centuries gone by. To give some idea of the brilliance of these spectacles and the splendor of some of these ceremonies has been my object in writing this book. The reader will not find it a history, but much that is historical is incidental to it; he will not find it a biography or a "character study" of the King or the Queen or of any member of the royal family, yet necessarily many things have been written which give glimpses of their traits and their tastes; he will not find it a volume of memoirs; nevertheless he cannot read it without realizing that of my life in Spain I have none but the pleasantest recollections, no memories except of the kindness uniformly and universally shown to me by the Spanish royal family, the Spanish Government, and the Spanish people.

It is a pleasure as well as a duty here to acknowledge my indebtedness to many who have aided me in securing illustrations for this work. Among them are Señor Franzen and Señor Kaulak, the two court photographers, whose pictures of the royal family are alike faithful as likenesses and artistic in their posing, their composition, and their finish, and stamp these two as peers, each of the other, and superior to all other photographers. To the publishers of those two up-todate, high class illustrated weeklies, Blanco $y$ Negro and Nuevo Mundo, I am indebted for permission to use some illustrations that have appeared in them. I am under special obligation 
to the Marques de Valdeiglesias, editor of $L a$ Epoca, of Madrid. Messrs. H. C. White \&. Co. of North Bennington, Vermont, whose series of stereopticon views of Spain is most extensive and excellent, have consented to the use of certain photographs. Several other illustrations appearing in this book were taken by Mr. John Randolph, who, while serving under me in the Legation at Madrid, travelled throughout nearly all Spain, and who has since written entertaining accounts of his journeys for various American publications. I am under very great obligations to Mr. Albert F. Calvert, of London, for a number of original photographs of the Royal Wedding. His unselfish kindness in making this contribution is but another of the many evidences of his disinterested service to Spain, which he has described so interestingly and instructively in that series of volumes, almost twenty in number, known as "The Spanish Series," treating of all sections of the country, as well as its principal cities, and its most notable painters.

Auburn, N. Y.,

William Miller Collier.

February 8, I912. 


\section{CONTENTS}

CHAPTER

PAGE

I. The Royal Family and the Royal HouseHOLD • . . . . . . . . . . 3

II. Titles of Nobility, Orders, and Decorations . . . . . . . . . . . 25

iII. The Presentation of Letters Credential . • • : : • • • • • • • • • 43

IV. The Marriage of an Infanta . . . . 71

V. A Royal Visit . . . . . . . . . 88

VI. The OAth to the Flag . . . . . . 108

VII. A King's Courtship . . . . . . . $\quad$ II7

VIII. The Royal Wedding . . . . . . . 137

IX. Wedding Festivities . . . . . . . 158

X. A Gala Day with Reception . . . . 186

XI. The Imposition of the Cardinal's Biretta 2I4r

XII. The Birth and Presentation of the Prince of Asturias . . . . . . . . . . . . . .927

XiII. The Baptism of the Prince and the Mass of Purification . . . . . . . . . 243 r

XIV. The Pope's Gifts, The Golden Rose, and the Fajas Benditas . . . . . . 258

XV. The Washing of the Feet, and Other

Religious Ceremonies . . . . . . . 269

XVI. A Palace Ball . . . . . . . . . 28I

XVII. Royal and State Funerals. Court

Mourning . . . . . . . . . . 295

XVIII. The Court and Madrid Society . . . 314 



\section{LIST OF ILLUSTRATIONS}

Their Majesties, the King and Queen of Spain . . . Frontispiece FACING PAGE

The Queen and her Children in 1910 . . . . . . . . . 6

The Infantes Don Carlos and Doña Louisa and their Family, Igr I 6

H.R.H. The Infanta Eulalia . . . . . . . . . . 12

The Royal Palace at Madrid from the Palace Gardens . . . I4

Escorial Palace: The Reception Hall . . . . . . . . . 15

Escorial Palace: Ante-room of Choice Woods . . . . . 15

Gardens of Aranjuez: Fountain of Apollo . . . . . . . ${ }_{16} 6$

Gardens of Aranjuez: Fountain of Ceres . . . . . . . . 16

Interior Views of the Alcazar Palace at Seville . . . . . . 17

The Palace at La Granja and the Fountain of the Three Graces 20

The Fountain of the Horse Race at La Granja . . . . . 20

Señor Moret, Prime Minister in 1906 . . . . . . . . . 26

The Salon of the Council of Ministers in the Royal Palace . . 27

The King in the Uniform of the Military Orders . . . . 38

The King as a Colonel of the Hungarian Army . . . . . 38

The King as Grand Master of the Four Great Military Orders . 39

Count Pie de Concha . . . . . . . . . . . . . 48

King Alfonso XIII in IgII. . . . . . . . . . . . 54

Her Majesty the Queen Mother, Maria Christina . . . . 72

H.R.H. The Infanta Isabella . . . . . . . . . . . 72

Wedding of the Infanta Maria Theresa; the Royal Family and their Royal Guests . . . . . . . . . . . 76

The Chapel of the Royal Palace . . . . . . . . . 77

The King in the Uniform of the Escolta Real . . . . . . 94

The Altar Erected in the Street . . . . . . . . . II2

The Military Governor and the Bishop of Zion. . . . . . 112

Pardo Palace: Salon of the Ambassadors . . . . . . . 126

Pardo Palace: The Dining Room . . . . . . . . 126

The King as an Automobilist . . . . . . . . . 127

Royal Yachting, the King at the Ropes . . . . . . . 127

Royal Box in the Private Theatre at the Pardo Palace . . . 132

The Queen in her Wedding Dress . . . . . . . . 138

The Royal Wedding, Princess Ena and the Queen Mother

Entering the Church . . . . . . . . . . . 150

The Bride and Groom in the "Coach of the Royal Crown" . I5I 
Three of Spain's most Celebrated Bull-fighters $\quad$ yaciNG PAG The Royal Palace: a Section of the Throne Room . . . . . . 196 Her Majesty, Queen Victoria in 1911 . . . . . . . . 197 The Halberdiers . . . . . . . . . . . . . 208

The Presentation of the New-born Prince of Asturias . . . . 236

The Prince of Asturias when about one year old . . . . . 237

The Prince of Asturias Taking his Brother Don Jaime out for a Ride.

The King with Don Jaime in his arms, accompanied by the Marquis of Viana

The Baptism of the Prince of Asturias

The Royal Children in 1910.

The Youngest Recruits in the Army: Don Jaime and the Prince of Asturias .

The Infantes Maria Theresa and Fernando with their Two Oldest

Children, 1910. . . . . . . . . . . . . . . 253

The Golden Rose . . . . . . . . . . . . . 258

The Hall of the Columns, Royal Palace . . . . . . . 270

Her Majesty, Queen Victoria in 1909 . . . . . . . 286

Royal Palace at Madrid: Salon Gasparini . . . . . . 292

Royal Palace at Madrid: Salon of the Mirrors . . . . . 292

The Escorial . . . . . . . . . . . . 298

The Royal Villa of Miramar at San Sebastian . . . . . 298

The Pantheon of the Kings at the Escorial . . . . . . 302

The Pantheon of the Infantes at the Escorial . . . . . . 302

Diplomats, Guests of Señor Allendesalazar, at Dinner in the Ministry

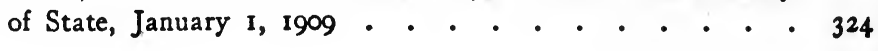




\section{AT THE COURT OF}

\section{HIS CATHOLIC MAJESTY}





\section{AT THE COURT OF}

\section{HIS CATHOLIC MAJESTY}

\section{CHAPTER I}

The Royal Family and the Royal Household

T $\mathrm{N}$ the Middle Ages the great monarchs of Europe, who were devoted to the Roman 1 Catholic Church, keenly coveted the honor of recognition, by some form of title, as champions of the faith. A good deal of acumen and tact and discrimination was shown by the popes in giving to each a title that would declare him to be a favorite son of the Church, without giving offence to others or preventing their receiving titles indicative of equal loyalty to its interests. The King of France was styled His Most Christian Majesty; the King of Portugal was called His Most Faithful Majesty; the King of Hungary was made His Apostolic Majesty; while the King of Spain, then, as now, prided himself on the title, His Catholic Majesty.

In the time of the great Emperor Charles the Fifth (who became King Charles I of Spain in 1516 ) and of his son Philip II, Spain was the foremost country of the world. Her armies overran all Europe; the rich Netherlands were still hers; the fairest parts of Italy belonged to her, and all 
4 THE COURT OF HIS CATHOLIC MAJESTY

the New World, by papal bull, had been awarded to her and to Portugal, which, in the time of Philip II, she absorbed. The greatness of the nation was personified in the monarch and found its expression in a strict and formal etiquette and in elaborate ceremonies and splendid pageants. When Philip V, the first of the Spanish Bourbons, became firmly established on the throne in 1713 , after the long years of the devastating war of the Spanish succession, the country had lost much of its prestige and had fallen from its high position of primacy. Still, this sovereign, mindful of the magnificence of the court of his grandfather, Louis the Great of France, embellished his capital and added to the splendor of the life of its court. To-day Spain has been stripped of most of her possessions and of much of her power, but her court ceremonies have been maintained with but little change; they remain stately in their formalities and brilliant in their coloring, dazzling to the eye, stimulating to the imagination, and quickening to the memory as they portray, in living pictures, the story of the nation's glorious past.

I propose to describe some of these ceremonies and pageants. What I shall write will be neither history nor biography; yet much that is historical is revealed in these ceremonies and not a little of human nature is reflected in them. The scene of these spectacles was the Court of His Catholic Majesty, Don Alfonso XIII. The time was the period when I was there as American Minister Plenipotentiary, 1905-1909. Some information as 
ROYAL FAMILY AND ROYAL HOUSEHOLD 5

to the dramatis persone is essential. It is necessary, therefore, that I first say something about the royal family and the royal household, and something about the nobility and the great orders.

When, in May, 1905, I presented my letters credential to King Alfonso XIII, he was not quite nineteen years of age, but had held the reins of government in his own hands since his sixteenth birthday. He was both boy and man; youthful in spirit and fond of sport; mature in judgment beyond his years, and of unquestioned will power. It was only a very short time previously that, according to his courtiers, he had indulged in the youthful prank of riding horseback up the grand staircase of the palace and into one of the salons; yet as constitutional King he was in those days choosing . Prime Ministers who, in fact as well as in theory, were largely the persons of his own choice, because the disorganized condition of political parties at that time gave none of the great statesmen and party leaders the right to say unqualifiedly that he had obtained or could obtain a majority in the Cortes, and the King was therefore entitled to use his own discretion in choosing his councillors and Ministers. In physique, also, the young King, in 1905, was developing from boyhood into manhood. He had a man's height, a boy's slight figure. $\mathrm{He}$ was nearly six feet tall, and weighed only about one hundred and thirty-five or one hundred and forty pounds.

Alfonso XIII was a posthumous son, born in 1886, about six months after the death of his 
father. Several writers who love to make statements that are sensational and bizarre have said, with some izaccuracy and less reverence, that he is the only person born a king since Jesus Christ. As a matter of fact, John I of France, son of Louis $\mathrm{X}$, was also a posthumous son and was born a king, but his reign lasted only five days.

Like all men, the present King of Spain is the product of both heredity and environment. From his father, Alfonso XII, he inherited affability, approachability, amiability. From his mother, Maria Christina, daughter of the Archduke Charles Ferdinand of Austria, who was a cousin of Emperor Francis Joseph, he inherited most splendid qualities; but what he is, is perhaps, in larger part, due to that loving, constant, self-sacrificing care and attention which she gave to his education, devoting herself not only to developing in him a strong physique, a high character, and a trained and cultivated mind, but also to the arduous task of administering for him the realm which he was later to govern.

In 1906 the King married the Princess Ena of Battenberg, daughter of Princess Beatrice of Great Britain, and therefore granddaughter of Queen Victoria of Great Britain. Before her marriage the young Princess was universally known as Princess Ena; since that time, officially as Queen Victoria Eugenia Christina, but popularly as Queen Victoria. I shall tell in another chapter the story of their courtship and of their marriage and of its glad festivities; sufficient now to say that it was from the beginning, and I believe 

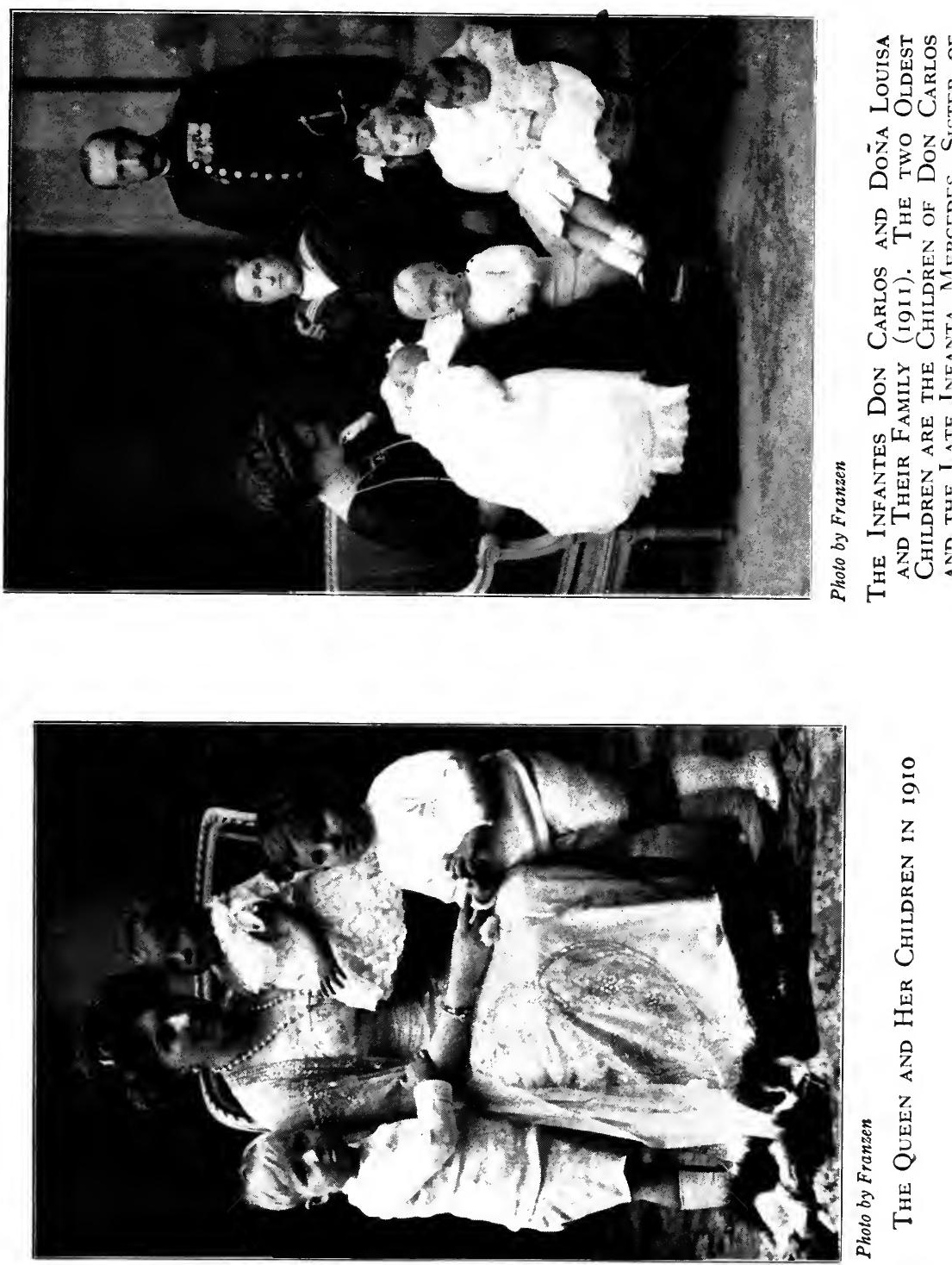
(n) 
now is and always will be, an idyl of love; for the young royal couple have congenial tastes and never seem more happy than when with each other. They now have four children: Alfonso, the Prince of Asturias, born May I0, 1907, about whose birth and presentation I shall write; Jaime (pronounced "Hi-me"), born in 1908; Beatrice, born in 1909; and Christina, the youngest, born December 12, 1911. The second of these was born in the year when Spain was celebrating the seven-hundredth anniversary of the birth of Jaime el Conquistador (James the Conqueror), a king of Aragon who greatly extended his dominions, bringing under his sway Catalonia, Valencia, and the Balearic Islands, and whose dream of a great Mediterranean empire long remained the ambition of Spanish sovereigns. The choice of the name of Jaime was a happy thought of the King, gratifying to sections of his realm which are not in that close contact with him which Castile enjoys.

The elder sister of King Alfonso, Maria de las Mercedes, six years his senior, was married, in 1901, to her second cousin, Don Carlos of Bourbon, second son of the Count of Caserta, the claimant to the throne of the old kingdom of the Two Sicilies merged by Garibaldi and Victor Emmanuel into the kingdom of Italy. The Count of Caserta had sided with the Carlists in the civil wars in Spain and had, indeed, been on the staff of Don Carlos the Pretender. For this reason, and also because the Spanish masses regarded the Bourbons of Naples as unlucky and the 
bringers of ill luck to others, there was great popular opposition to this marriage; yet, as it was in every sense a love match between persons well suited to each other, it had the approval of Maria Christina. Amidst wedding bells and palace festivities, the manifestations of popular disapproval took the form of riots in the streets, to suppress which troops had to be called out. Nevertheless it was a happy marriage, and its unpopularity was soon dispelled. To-day no one is more highly respected by the citizens of Madrid than the Infante Don Carlos, who by devotion to his military career has attained the rank of general.

Great sorrow came to the royal family and the nation when, in 1904, Maria de las Mercedes died. She had just given birth to a daughter, who survived her and who is now over seven years old. She also left two young sons who bore those names so common in Spanish history, Alfonso and Fernando. The former, after the death of his mother and until the birth of a son to the King and Queen, in 1907, was heir presumptive to the throne and with his father lived in the Royal Palace. The second son, Fernando, died when two years old. Of his funeral and of his burial in the Pantheon of the Infantes in the Escorial, I shall tell in another chapter. In 1907, after the birth of a son and direct heir to the King, and when his own son was no longer heir presumptive, Don Carlos married Princess Louise of France, daughter of the late Count of Paris and sister of the Duke of Orleans, claimant to the throne of France, also sister of Queen Amelia 
of Portugal, the Duchess of Guise, the Duchess of Aosta, and the young Duke of Montpensier. Don Carlos and his family then vacated their apartments in the Royal Palace and purchased a very handsome and spacious palace in the Paseo de Castellana, Madrid's most beautiful street. By his second wife Don Carlos has three children. Three brothers of Don Carlos, the princes Gennaro, Reniero, and Philip, although not belonging to the Spanish royal family, are related to it as second cousins of the King, and they live in Spain, where they are officers of the army and navy and are frequently seen at court functions.

The King's younger sister, the Infanta Maria Theresa, is nearly four years older than himself. In her personal appearance and in her distinction of bearing she greatly resembles her mother. Like her, she is devoted to religious and charitable work. Like her aunt, the Infanta Isabella, she is passionately fond of everything Spanish, and by her presence at all the national games, sports, and fiestas she shows her sympathetic interest in them and gives them her hearty support. She is consequently popular with the masses. She was married at Madrid, in 1906, to her first cousin, Prince Fernando of Bavaria, son of Prince Ludwig Ferdinand and Princess (Infanta) Paz, a sister of King Alfonso XII. Prince Fernando was naturalized in Spain, made an Infante, and is now a captain in the regiment of the Hussars of Pavia. Until the birth of the Prince of Asturias he and his wife lived in the Royal Palace, but they now reside quite near it, in a smaller 
but beautiful mansion. They have two young sons, Luis and José, and a daughter born in October, I9II, and named Maria de las Mercedes, in honor of Maria Theresa's sister.

Three aunts of the King are living. Of the oldest, the Infanta Isabella, born in $185 \mathrm{I}$, it can be said without disparagement to the others of the royal family that none of them enjoy greater popularity. She possesses so fully the national temperament, displays such a lively interest in the customs and sports of the people, is so kind, generous, and cordial, that she is liked by all classes. She married the Count of Girgenti, one of the Neapolitan Bourbons, but she was early widowed. Nearly all her life has been spent in Spain, except when she shared the exile of her mother, Isabella II, after the latter's loss of the throne, in I868. She is familiar with every nook and corner of the country, having automobiled through it - or, more strictly speaking, through those parts where there are roads. She has also travelled abroad extensively. In I9ro she was the representative of Spain at the celebration, in Buenos Ayres, of the centennial of the independence of Argentina. She is an excellent musician, fond of literature and art, and is a patroness of painters and men of letters. She is addicted to outdoor sports, likes to hunt and to drive a fourin-hand, and enjoys no less all indoor entertainments, always participating in the dance, leading the cotillion, making everyone feel at ease, and putting life into every company where she is present. She lived in the Royal Palace during the minor- 
ity of the King, but when the regency ended she went to reside in a palace about half a mile away. The Infanta Paz, another aunt of the King, married, as I have said, Prince Ludwig Ferdinand of Bavaria; she lives at Nymphenburg, just out of Munich. Besides her son, the Infante Fernando, who married the King's sister, she has two children, Prince Adalbert and Princess Pilar, the latter bearing the name so common among Spanish women, Maria del Pilar. This name was given in honor of the highly adored Virgin at Zaragoza, who, in ancient days, appeared standing upon a pillar before Saint James, the Spanish Santiago, who, reincarnate, led the Christians in battle against the Moors. The Infanta Paz is a painter of considerable talent and a poet whose verses have been favorably criticised. She is active in church work, and her home and family have been so happy that "Her Royal Highness, the Most Serene Señora Infanta Doña Paz" seems to be not only her title, but an epitome of her life. Her husband, Prince Ludwig Ferdinand, nephew of the Prince Regent Luitpold, is a soldier and physician, but he is more devoted to curing than to killing; in Munich as well as in Madrid, when he visits that city, he does much unselfish work as a surgeon in the military hospitals. Prince Ludwig Ferdinand, like his son, married his first cousin, for he was a son of the Princess Amelia, a sister of Francisco de Assisi, the husband of Isabella II, and father of the Infanta Paz.

The Infanta Eulalia, the third aunt of the King, has a palace in Madrid and spends two or three 


\section{I2 THE COURT OF HIS CATHOLIC MAJESTY}

months in it each Spring, but during the greater part of the year she lives in Paris. She married Prince Antonio of Orleans, brother of the Countess of Paris and of Mercedes, the first wife of her brother, Alfonso XII. He was her first cousin. She is a woman of great beauty and grace and of exceptional elegance. She is cosmopolitan in her tastes and has travelled a great deal. She was the royal family's representative at the World's Columbian Exposition at Chicago, in I893, and is a great admirer of American energy. She has two sons, the Infante Don Alfonso de Orleans y Bourbon and the Infante Don Luis Fernando. The former, in 1909, married Princess Beatrice of Saxe-Coburg, daughter of the late Duke of Saxe-Coburg, formerly the Duke of Edinburgh, son of Queen Victoria of Great Britain. She is therefore a cousin of Queen Victoria of Spain. The course of true love does not always run smooth, even with princes and princesses. The mother of Princess Beatrice of Saxe-Coburg was the Grand Duchess Marie, daughter of the Czar Alexander II of Russia, who was assassinated in I88r. Princess Beatrice, therefore, knew something of the tenets of the Greek Church. She was born in England when her father was still the Duke of Edinburgh, and she was, therefore, in childhood a member of the established Church of England; and when her father became the Duke of Saxe-Coburg, the family was, at least officially, connected with the Lutheran Church. But Princess Beatrice was not a Roman Catholic, and consequently upon his marriage to her the 


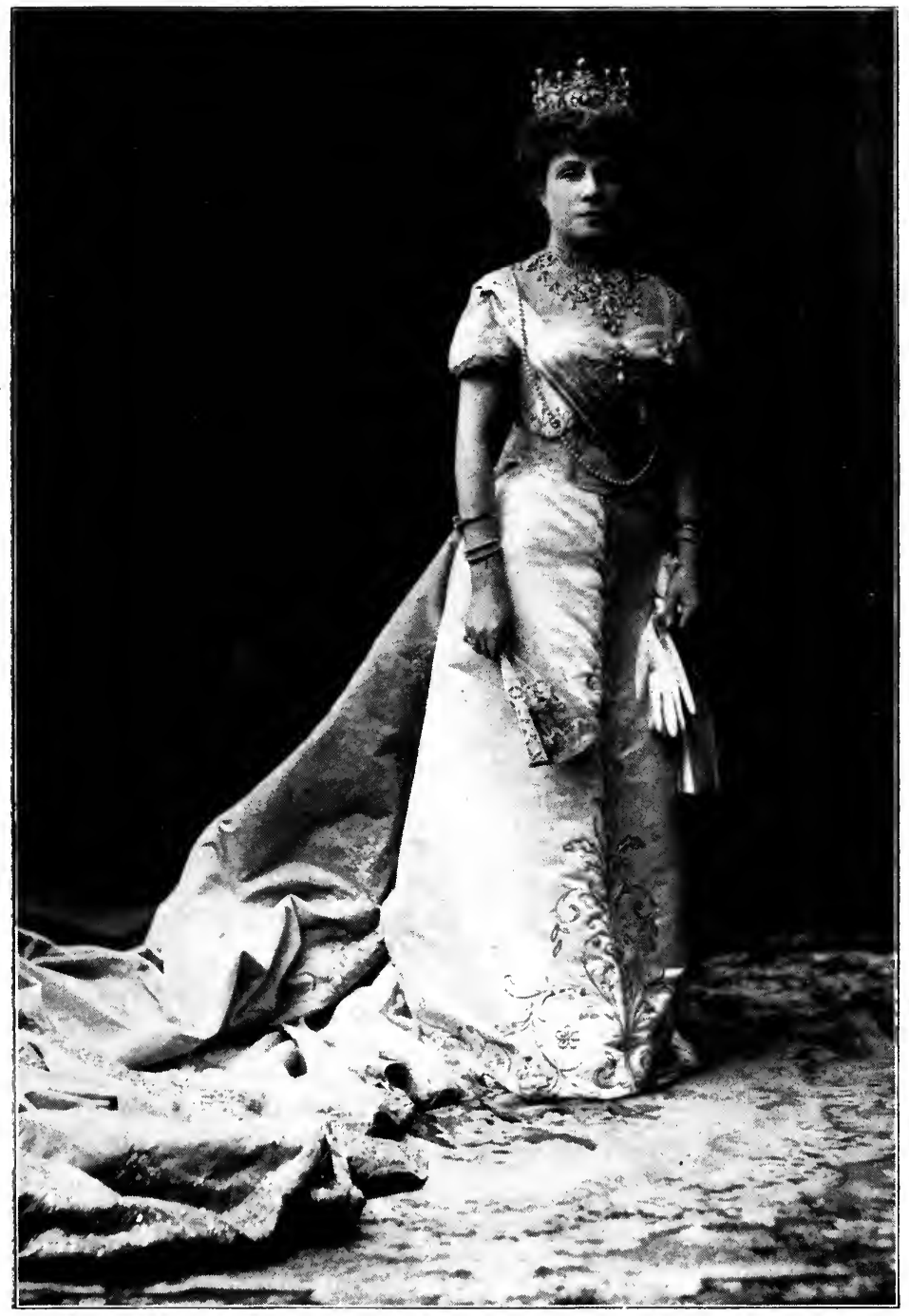

Photo by Franzen

H.R.H. The Infanta Eulalia 

ROYAL FAMILY AND ROYAL HOUSEHOLD I3

Infante Don Alfonso forfeited all his titles and honors and rank in Spain. It is reported, however, that these are likely to be restored to him by royal decree.

The King and Queen of Spain have many residences in their dominion. First and greatest of all is the Royal Palace at Madrid. Six miles from it is the Palace of the Pardo, in the midst of a vast domain partly used for agricultural purposes and partly as a game preserve. To this palace the royal family make almost daily excursions. About thirty miles south of Madrid, on the river Tagus, is the Palace of Aranjuez. Its gardens, in early Spring, are of entrancing beauty, almost semi-tropical in the luxuriousness of their vegetation. A hundred years ago it was a favorite residence of the kings, but now it is never used except as the objective point of an afternoon's automobile trip. Schiller, who laid the scene of his "Don Carlos" here, has said of it: "The happy days in fair Aranjuez are past and gone"; yet it remains a veritable paradise. At Seville the King has the ancient Alcázar, a palace in the Moorish style, built about a century after the Alhambra, but by constant restoration kept in repair, and to-day giving us a feeble idea of what the now ruined and faded palace at Granada must have been like.

The Escorial, thirty miles or more from Madrid, is monastery, college, church, pantheon, and palace, combined in one vast building. It was well fitted for the gloomy temperament of Philip II, who conceived, planned, and built it, 


\section{I4 THE COURT OF HIS CATHOLIC MAJESTY}

but modern kings have preferred that it should be their last resting-place after death rather than their home during life. At La Granja, not far from the Escorial, in the Guadarrama Mountains, is the Palace of San Ildefonso, which is the favorite residence of the present King and Queen. Its grounds are finely laid out, and it has cascades and fountains that rival or surpass those of Versailles. It cost Philip V, the grandson of Louis the Great, an enormous sum, and before it was finished he was tired of it. When the Bath of Diana, one of the great fountains, played for the first time, the jaded monarch said: "It has cost me three millions, and it has amused me three minutes." The villa of Miramar, overlooking the Bay of San Sebastian, was built by Maria Christina when she was Regent, but is her own personal property. It is there that the royal family, during all the years of the King's youth, up to the time of his marriage, spent all the Summer months; and although Queen Victoria very much prefers the cooler mountain air of La Granja, the King and she still go to Miramar for several weeks each year. A new palace is being built for them at Santander on the coast of the Bay of Biscay, and doubtless it will be in the future their Summer residence.

The Royal Palace at Madrid was commenced by that same Philip V who had spent such enormous sums at La Granja. And though he had wearied of that palace, he planned one for Madrid that should be the wonder of the world. It was to surpass in size the Escorial of Philip II, and in 


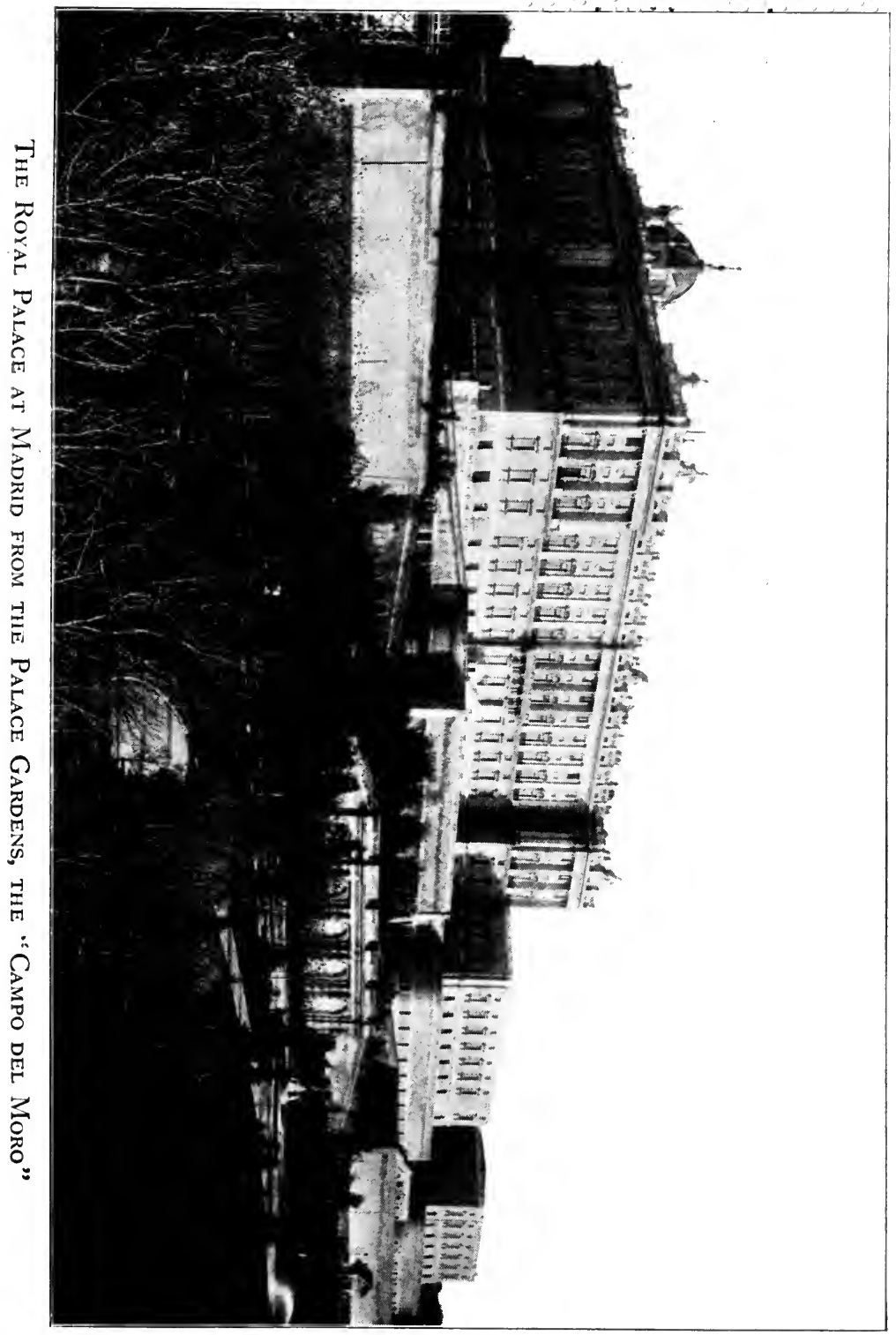




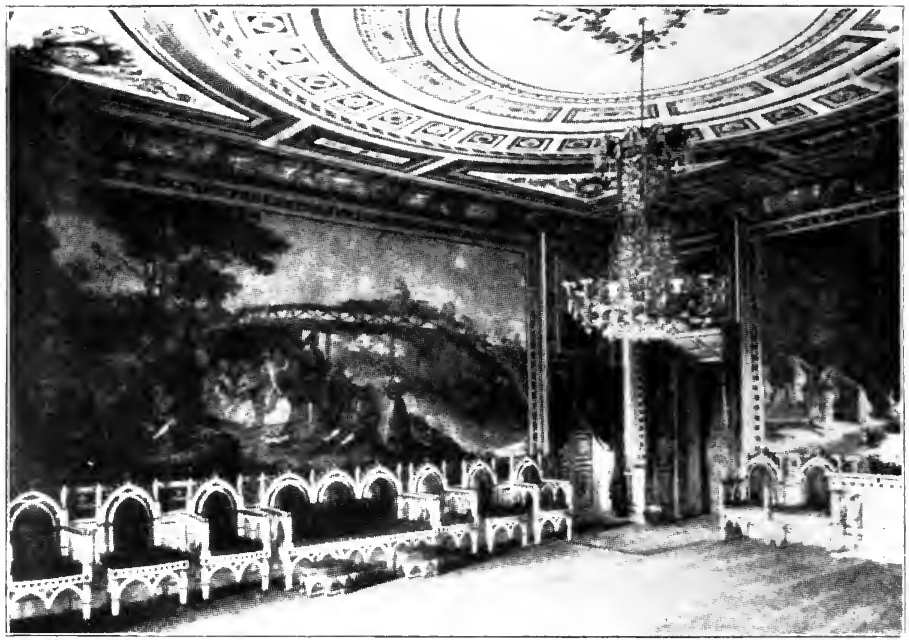

Escorial Palace. Recertion Hall

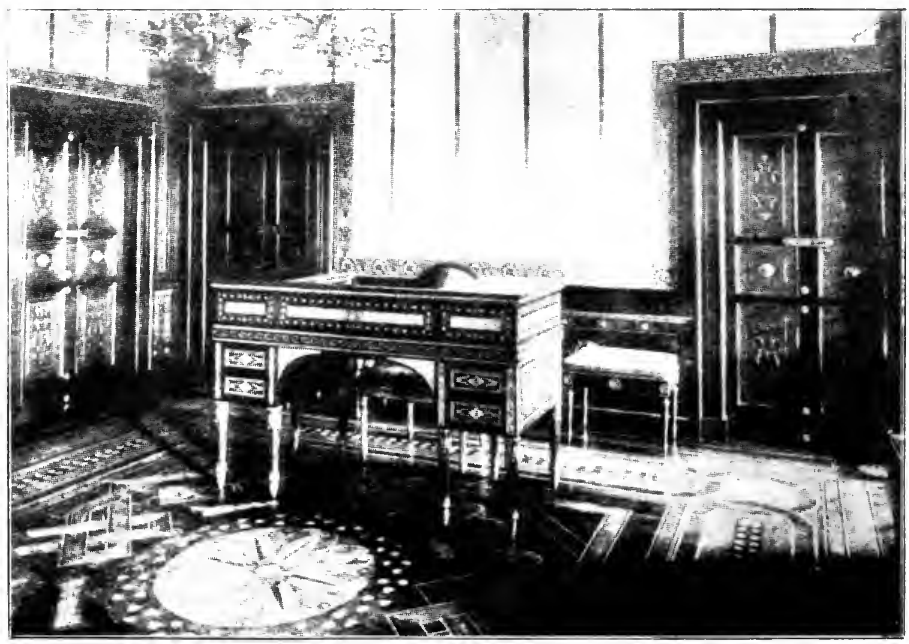

Escorial Palace. Ante-room of Choice Woods 
splendor was to outstrip the Versailles which his grandfather, Louis XIV, had erected in France. You may see the colossal model of it still preserved in the Madrid museum. It was to have four façades, each seventeen hundred feet long, and was to have twenty-three courts and thirtyfour grand entrances, and to contain gardens and theatres and apartments and offices, and to be a palace of palaces, the like of which no one had ever seen, no one had ever conceived. But. Philip's building plans clashed with his wife's ambitious designs for the advancement and enrichment of her children. She preferred for them money in hand rather than such magnificent palaces whose cost and maintenance would mean the bankruptcy of the nation. So Philip's original plan was abandoned, and the present palace was constructed on the site of the old Royal Alcázar, which had been a residence of kings and rulers from far-off mediæval times, when the Moors sat in power in Madrid. This palace, which Philip actually started in 1738 and which his son Charles III actually completed twenty-six years later, is one of the largest, handsomest, and most picturesquely situated palaces in all Europe. Few can equal it, none can surpass it, in the union of all these qualities combined with architectural merit and richness of interior furnishing and decoration. It is five hundred feet square and one hundred feet high.

The size of this immense residence, the traditions of the monarchy, and the customs of the Spanish people necessitate an army of servants. 
Even the number of dependents of this class in the houses of grandees is very great. It is said that the Duke of Arcos who died in 1780 maintained three thousand persons as servants, or as retired and pensioned servants. In the Royal Palace and its grounds and in the stables (where are kept more than two hundred and fifty horses and mules) the number is, of course, legion.

This great property requires also a very large number of persons of executive ability for its ma. agement, administration, and inspection. These, like those who render less onerous services of a ceremonial character, are, in Spain, considered members of the real casa, the royal household. They are many in number, and the variety of their duties is infinite. There are court physicians and court pharmacists, inspectors, managers, and superintendents, librarians, archivists, secretaries, and cashiers, architects and engineers, - all with offices in the palace, all employed therein exclusively, all with high-sounding titles, all with important duties and with prerogatives that they jealously assert.

But besides these there are hundreds of others who form a part of the royal household. The elaborateness of the ceremonial surrounding the life of the royal family, the splendor of the pageants of the court, and the maintenance of the dignity of the sovereign make indispensable a multitude of palace functionaries who constitute the retinue and the suite, - the court, in a restricted sense. Victor Hugo in his "Ruy Blas" satirized this condition of affairs as it existed two 


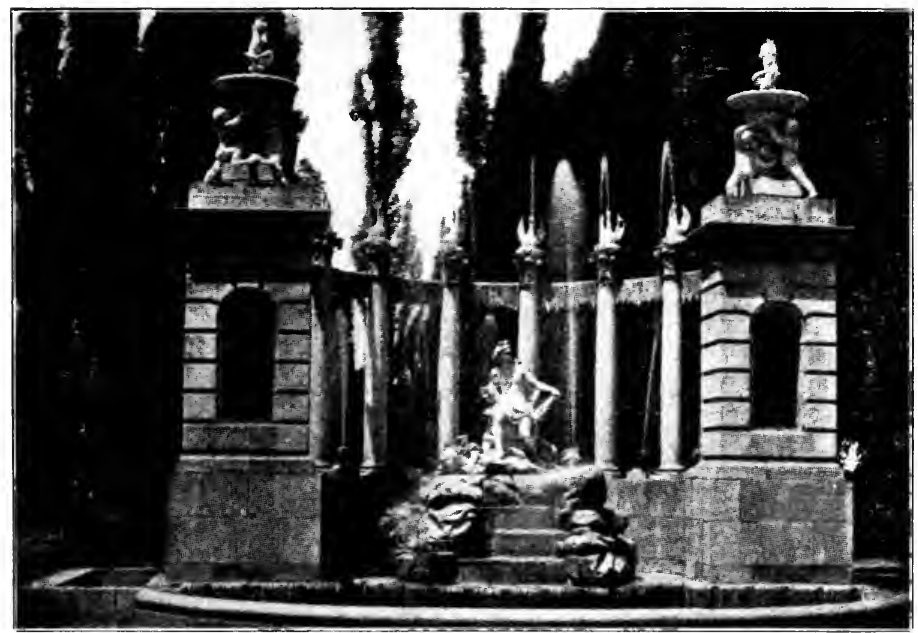

Gardens of Aranjuez. Fountain of Apollo

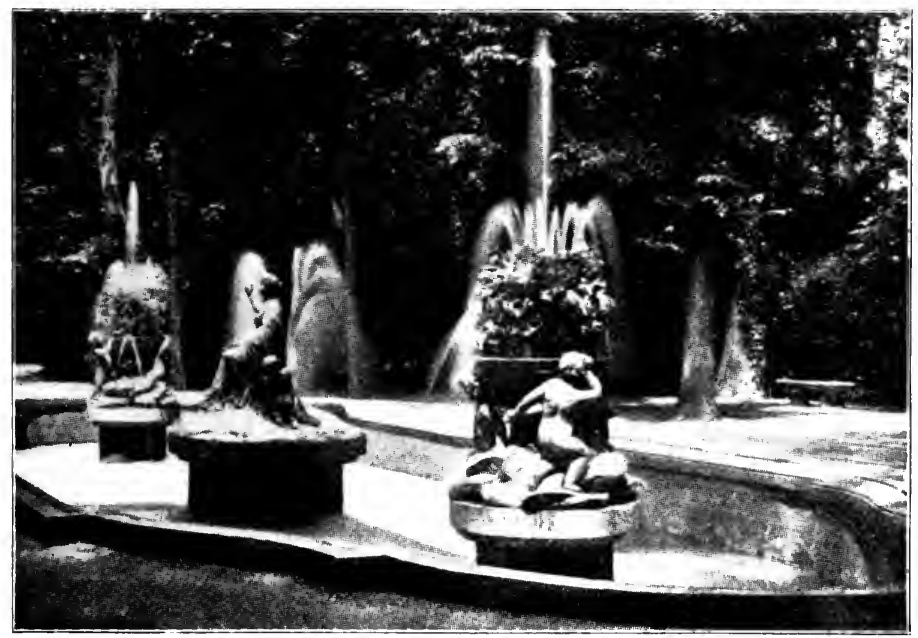

Gardens of Aranjuez. Fountain of Ceres 

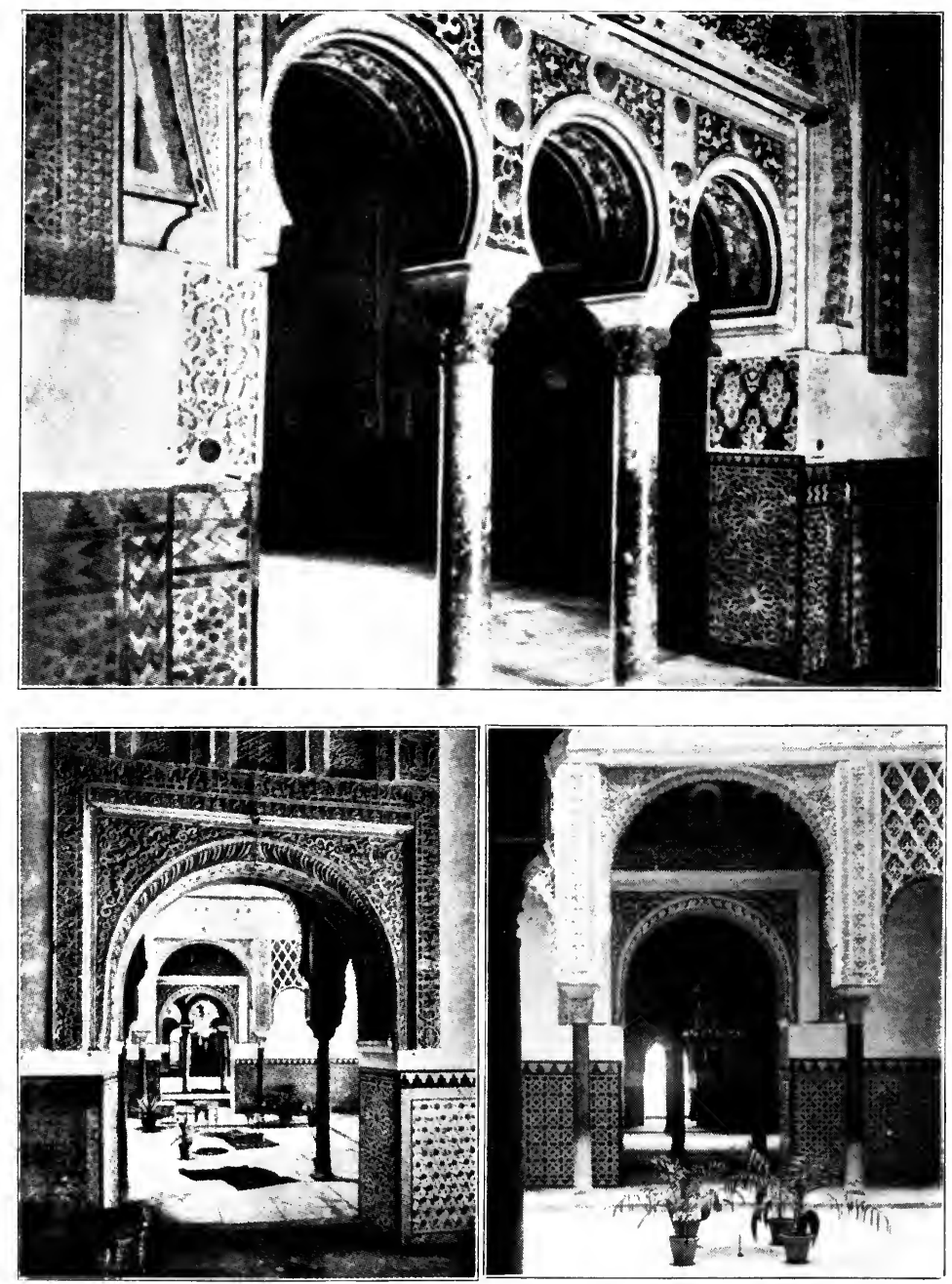

Copyright 1908, H. C. White Co., No. 10,917

Interior Views of the Alcazar Palace at Seville 
hundred years ago. Doubtless he exaggerated, but there is in his play an element of truth applicable even to-day. The personnel of the court is a numerous one. The:vast majority have only nominal duties, yet not a few render actual but honorable service and receive compensation; so that the annual allowance made by the Cortes to the King, of seven million pesetas (equal to nearly $\$ \mathrm{I}, 400,000)$, enormous as it is, is subject to many charges.

If we would understand the court ceremonies in all their significance, we must learn something about this great body which constitutes the royal household. First and foremost is the Sumiller de Corps, Jefe Superior del Palacio. His functions correspond somewhat with those of the Lord Chamberlain in England or of the Grand Maitre of the old French régime. In Spain he is also Guard of the Seals and Supreme Chief of the Palace. He it is who is the final arbiter of all questions of court etiquette. Then there is the Mayordomo Mayor, who, in some respects, may be considered the Lord Steward, although his functions relate to etiquette and ceremonial rather more than to administration, and he is virtually Vice-Sumiller de Corps. The Caballerizo y Montero Mayor (Grand Master of the Horse and of the Hunt) was in ancient times supposed to charge himself with everything relating to the royal stables and to the royal chase, and even to-day he exercises such an oversight, although, in fact, he is usually the King's companion on all his journeys. There is also the General in Command 
of the Royal Halberdiers, who is Chief of the Military Household. These four functionaries are called the Palace Chiefs. They are always grandees of Spain; they are the officials who form His Majesty's immediate suite on all ceremonial occasions, walking behind him or riding behind or with him in processions, and standing behind his throne when he occupies it.

Under these four Palace Chiefs is a great variety of functionaries whose titles indicate services which they actually rendered in ancient times. There are Gentileshombres (Gentlemen) of many classes. Gentileshombres de Casa y Boca (Gentlemen of the House and Mouth), in days not remote, waited on the King at table and aided him in dressing and undressing, but to-day have no more strenuous task than to form the suite of the King on state occasions. M. Bourgoing, Minister of France at Madrid, in the reign of Charles IV, a little more than a hundred years ago, said, in his book, "L'Espagne Moderne":

"The King dines with his wife. Behind their chairs stand the Grand Almoner and Chaplain, the Lord Chamberlain, the Captain of the Royal Guard, and one of the soldiers thereof. The table is served by two lords in waiting who are grandees of Spain, one of whom serves the food and another the wine, kneeling at the feet of the King as they do so. The same honors are rendered to the Queen by the ladies in waiting and to the Infantes by the titled persons who are in their service. Philosophy may grow indignant at the aspect of this obsequious homage, but it does not belong to Spain exclusively. Similar honors are rendered at the Court of Vienna and even at London, where the monarch's authority is circumscribed in so many respects." 
Besides the Gentlemen of House and Mouth there are nearly fifty Gentileshombres de Entrada (Gentlemen of the Entrance), so called because they may enter certain rooms reserved for the higher court dignities, and about three hundred Gentileshombres con Ejercicio (Gentlemen with Exercise). Very great personages are the Most Excellent Señores, the Lords of the Bedchamber with exercise and service, grandees of Spain, of whom there are about one hundred and fifty. There are also about one hundred and fifty Mayordomos de Semana (Chamberlains of the Week), who, each in his turn, serve for this period of time. When they are on duty all these several classes of court functionaries wear distinctive uniforms or court dress, very elegant and very elaborate, especially on days of ceremony.

So far, I have mentioned only men; but the ladies form a numerous and important element at court. At the head is the Camarera Mayor or Grand Mistress of the Robes. Always a grandee of Spain, she is the first lady of the land next to the princesses; and it may be truthfully said of the present incumbent, the Duchess of San Carlos, that a woman more noble in character, more distinguished in bearing, or more highly cultured could not be found. She is the chief of the ladies of the Queen and is Her Majesty's constant companion on all ceremonial occasions. There are about sixty ladies of the Queen. This is the honor to which every Spanish woman of high position aspires. Daily, in rotation, one of them spends the afternoon at the palace, aiding in re- 
ceiving those who are to have audiences of the Queen, dining with the royal family, and afterwards accompanying them to the theatre or opera if they attend it. On occasions of great ceremony the entire body of ladies of the Queen, all wearing court dresses with long trains, follow the Queen. They all have, as a badge of their office, a diamond pin forming the monogram of the Queen. Almost all of them are also members of the Order of Maria Louisa and wear its purple and white band.

When the King goes out to ride or to drive in state, he has caballerizos (equerries) and mon-. teros ("beaters") at the side of his carriage or horse. Monteros originally beat the forest in the royal chase, to rouse the game. To-day, while they go with the King on hunting expeditions, their usual duty is to accompany him in royal parades and progresses.

Kings-at-arms are a mere souvenir of an ancient office, yet a most picturesque one. In ancient days they were nobles of the highest order whose duty was to observe and give notice to the King of feats of arms and acts of daring by the warriors, to recommend them to the sovereign for recognition and ennoblement, to proclaim in the King's name his declarations of war, and to give notice of the conclusion of peace. As insignia they wore the King's arms. To-day they largely serve to recall the past, but they still preserve the outward show of their former greatness. They still make certain proclamations in the King's name and have charge of heraldic records 
and certify as to lineage, coats of arms, and similar matters. They are the most conspicuous figures on great ceremonial occasions. They wear long red velvet coats with broad sleeves, such as were worn in ancient Dalmatia and therefore called dalmatics. The arms of the King, in figures of great size, are embroidered thereon. The kingsat-arms stand at the four corners of the throne or the raised dais upon which the monarch sits. As Spain is a union of four ancient kingdoms, Castile, Leon, Aragon, and Navarra (with many smaller ones), there are in that country four kings-at-arms, each with the arms of one of these old kingdoms.

Within the palace, to guard the royal family, is found the Royal Guard of the Halberdiers, a corps whose organization dates back to 1504, the year in which the great Isabella died. There have, of course, been many reorganizations of it. It numbers only two hundred and ninety men. The King is the colonel of it, and a lieutenantgeneral of the army is the active commander, but holds in the halberdier corps only the rank of captain. Its members wear a uniform adopted about a hundred years ago, consisting of a threecornered hat, tight fitting coat, knee breeches, and cloth gaiters buttoning up to the knee. For gala they wear white breeches, red coats, hats trimmed with silver braid, top-boots. The most conspicuous weapon carried by the halberdiers is the ancient halberd, a combination of long spear and battle-axe. Its members, however, also carry swords, and they have guns and bayonets to 
use in case of need. That they know how to handle them was proven in $184 \mathrm{I}$ when General Leon, at the head of two squadrons of soldiers, endeavored to enter the palace and kidnap the young Queen Isabella II, then eleven years old, and her still younger sister, the Infanta Louisa Fernanda, who afterwards married the Duke of Montpensier. The invading soldiers were repulsed after a long and bloody struggle on the stairway of the palace, and General Leon was captured and the next day was shot.

For many centuries the kings of Spain have been guarded at night during their slumbers. (as well as after death until placed in their tombs) by a small band, never exceeding twelve, known as the Monteros de Espinosa, serving in rotation by couples. At eleven o'clock at night, if the King and Queen are in the palace, the doors are locked with great ceremony and the keys of the royal apartments given over to the two monteros who, in the room adjoining the one where the King sleeps, pace up and down all night. Originally this service was limited to persons born in the little village of Espinosa, and was hereditary in certain families. It was considered a great honor, and it was not infrequent to hear it said of women living in Madrid, but belonging to Espinosa families whose members would be eligible for this post if born in that place: "Oh, she has gone to Espinosa, there to await the birth of her son." This privilege was conferred by, one of the early kings upon the inhabitants of this village because they had revealed to him a plot of 
treason formed against him. But in recent years, although the guard and watch are maintained exactly as in centuries gone by, the monteros are chosen from retired captains and lieutenants of the army.

In a court whose ceremonies are so closely related with the services of the Church, the ecclesiastics of the royal household form an important element. The Archbishop of Toledo is the Primate of Spain and, in a sense, is the religious head of the Royal Palace, but the Pro-Capellan Mayor (Grand Almoner and Grand Chaplain) is the actual or acting chief. To him the Pope has given the titular bishopric of Zion. Under him there are no less than eighteen Chaplains of Honor to assist in the services in the Royal Chapel, besides four Sumillers de Cortian or Chiefs of the Curtain, clergy whose duty it used to be to draw the curtain that screened the royal throne or chair of state when not occupied. But now there is no curtain in front of it; so, though their office exists and their title is not changed, the duties are different from what they once were.

As an escort, rather than as a guard, the King has a most imposing squadron of cavalry called the Escolta Real (Royal Escort), first organized by his father, Alfonso XII. It consists of a troop of select men of fine personal appearance, splendidly mounted, and most handsomely uniformed. They always accompany the King when he goes anywhere in Madrid on great occasions of ceremony. His Majesty at other times is very fond of putting himself at their head and at a quick 
pace conducting them for a long ride in the country.

In addition to these a military guard is stationed throughout the day in the Plaza de Armas, within the palace enclosure. It consists of twentyfive cavalrymen, a battalion of infantry, and a battery of artillery, furnished daily, in turn, by the different garrisons of the city. The military ceremony of the change of the guard every morning at ten o'clock is most interesting and never fails to attract a crowd.

The band of the Halberdiers enjoys a very high reputation. Its repertoire is extensive, particularly of the hymns and marches of all nations, which it has frequent occasion to play when foreign sovereigns and princes are guests of the King of Spain, as well as when ambassadors present their credentials.

Not only has the King his Mayordomo Mayor, but the Queen also has such a functionary besides her Grand Mistress of the Robes and her ladies in waiting; and the Queen Mother, Maria Christina, who still retains her apartments in the Royal Palace, and the Infantas who live in other palaces, have each a Mayordomo or Jefe de la Casa, or head of their house, and one or more ladies in waiting. 


\section{CHAPTER II}

Spanish Titles of Nobility, Orders, and Decorations

OTRICTLY speaking, the nobility as a body does not form a part of the royal household - the court in the limited sense of the word; yet a great majority of the suite and retinue of the King, and all of the alta servidumbre, or "high service," belong to this class, being either the possessors of titles or heirs to them. Neither are the nobles in Spain the controlling factor in government. In this respect their power is less than that of the same class in almost all other countries. There is in Spain no House of Lords, as in England. The Senate of the Realm contains about three hundred members, one half of whom are elected by the provinces. The other half are either appointed by the crown or hold their seats "in their own right." Of the latter, nine are the archbishops and at present thirtyeight are grandees of Spain who possess the required qualification; namely, an annual income equal to twelve thousand dollars. But a large proportion of the Senators nominated by the crown are nobles, while very often members of this class are elected by the provinces, and not infrequently they represent constituencies in the House of Deputies. The direct influence of this 
class upon the government of the country is, therefore, important, although the Prime Ministers and the great party leaders have generally not been titled persons. Since the birth of Alfonso XIII there have been at least a dozen Prime Ministers and not more than one or two have been nobles. Cánovas del Castillo, Sagasta, Silvela, Azcarraga, Maura, Moret, Montero Rios, Villaverde, Lopez Dominguez, and Canalejas have none of them belonged to the nobility. Indeed, the great political leaders, as a rule, seemed to hold titles in indifference, if not in contempt, except as rewards which they could give to their followers. The two following stories, both well vouched for, attest this.

Of Cánovas it is related that Maria Christina, when Regent, wished to confer a title upon him, and so informed him. He cleverly expressed his disinclination to accept it by saying, "Oh, Madam, it is you and I who make dukes and marquises. Why does Your Majesty wish to lower me?" However, after Cánovas was assassinated his widow was made Duchess of Cánovas del Castillo, and the title upon her death passed to her nephew, who also holds the title of Duke of Arion.

Sagasta, the great rival of Cánovas, showed even greater reluctance to being ennobled, and Maria Christina was less direct in her offer of a title. It is said that on a certain occasion he, with others, accompanied the Queen Regent to inspect some new works at the Escorial. She stepped upon a scaffolding which was insecure, and nearly fell. Sagasta caught her by the arm 


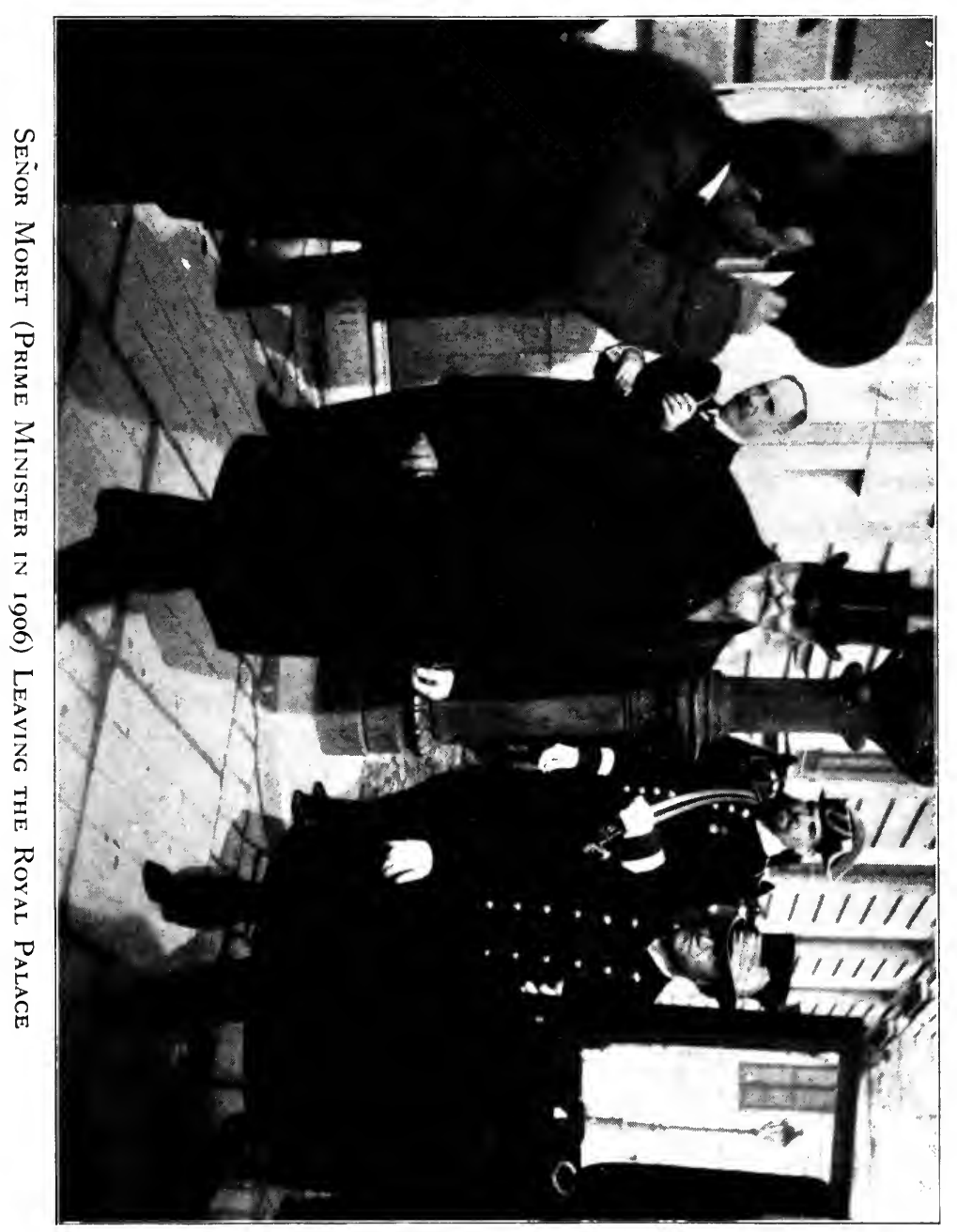




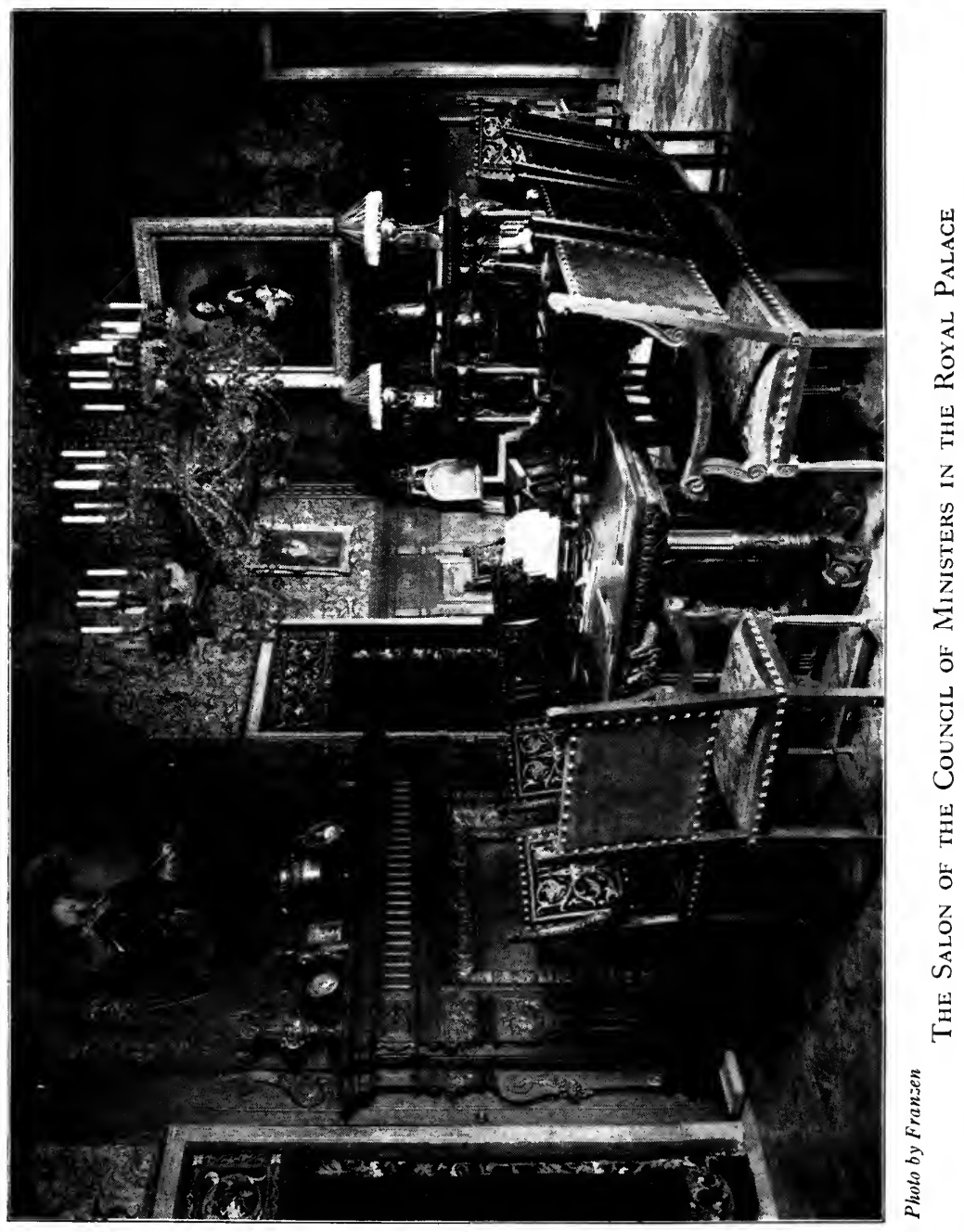


and saved her. Laughingly the Queen Regent said to him: "Do you not remember the old Spanish law which made it a crime punishable by death to touch the Queen, - unless," she significantly added,."one was a grandee of Spain?"

"In that case, Madam, I choose death," replied Sagasta.

Still, he afterwards accepted the Order of the Golden Fleece, and after his death his daughter received the title of Countess of Sagasta. Her action and that of the wife of Cánovas del Castillo would seem to prove that titles have a special charm for the female sex.

Nevertheless the influence of persons of title is great, both directly and indirectly. The honors are much sought after, despite the fact that a heavy tax running from fifteen hundred to three thousand dollars is imposed on them when first granted or when inherited, besides an annual tax thereafter. The present Duke of Alba, possessor of very many titles, paid as a succession tax upon them, in 1902, nearly one hundred thousand dollars. To a greater or less degree titles fix social position. As rewards eagerly desired they are, like orders and decorations, a source of patronage and power to the Government.

Titles are common in Spain. Their value has undoubtedly been lessened by the liberality with which they have been bestowed. The tax has not been reduced, yet the demand continues, and the supply seems inexhaustible. There are in Spain to-day one hundred and twenty ducal titles, more than a thousand marquisates, over seven hundred 
and fifty titles of count, about a hundred viscountships, and one hundred and twenty baronies. It will be noted that the pyramid stands on its top instead of its bottom, the orders of lowest degree having fewest members. In fact, in modern times a baron or a viscount or even a count is rarely created. One does not pass through the grades, as in England, but, if ennobled, is almost invariably made a marquis at first breath. Sometimes even the ducal title is the first given.

It may be wondered where enough names can be found for all the titles, and indeed looking over the list, it would seem as if all the names of places in Spain had been appropriated. A person ennobled usually chooses as his title the name of some town, village, parish, castle, or estate where his family has lived, or he couples with the title his family name. But of ten some event or some service which was the occasion of his receiving the title is chosen as the title itself. Thus in the list of titles of the realm in the Guia Oficial one sees Marques de la Concordia Española del Perú, to commemorate someone's service in 1812 in establishing harmonious relations between Spain and the country which was then her colony; also the Conde del Real Aprecio (Count of the Royal Appreciation); also Marques del Real Transporte (Marquis of the Royal Transportation), a title which Charles III, in 1760 , gave to the person who had charge of the ship upon which he crossed from Naples to Spain upon his accession to the throne of the latter country. We also find in the Guia such titles as Marquis 
NOBILITY, ORDERS, AND DECORATIONS 29

of the Dragon of Saint Michael of Hijar, Marquis of the Royal Proclamation, Marquis of the Royal Defence, Marquis of the Royal Succor, Marquis of the Reunion of New Spain (Mexico), to commemorate the reunion sometime prior to $182 i$, and Count of the Royal Mercy (Conde de la Real Piedad). Most remarkable of titles is one granted in the year 1867, Marques de los Remedios (Marquis of the Remedies). It is commonly said, in Madrid, that this was conferred upon a physician who had rendered some eminent services. I am not able to verify this statement, neither can I gainsay it. It is barely possible that it may have had another origin. Perhaps it was derived from the islands or from the town known as Los Remedios; it is, however, more probable that the popular report as to its origin is correct.

In many respects Spanish rules as to the granting of titles and their devolution are peculiar. They are not infrequently conferred upon women and may be inherited by them as well as through them, and by courtesy husbands use the titles of their wives. In default of direct heirs, titles pass to collaterals. They, therefore, rarely lapse, but on the contrary tend to centralize in a few persons. Thus the Dukes of Medinaceli and Alba have seven or eight different ducal titles and about fifteen or twenty titles as marquis, count, viscount, or baron. Many others of the nobility have several titles. There are consequently fewer titled persons than titles. As a rule they descend to the first-born son, but there are legal 
steps that can be taken which make it possible for one in his lifetime to transfer or revive a title in favor of a son or daughter, and such titles are of ten granted as coming-of-age presents or birthday gifts. Not infrequently all the members of a family have titles, all of course different, making it exceedingly difficult for the stranger to group people in families. I knew one family consisting of mother, two young sons who were not of age, and two daughters, both débutantes, each of whom had his or her own distinctive title. One loses all track of family names. In fact, nine times out of ten, the Spaniard will speak of another whose name may be Don Juan Fulano, but whose father has the title of Duke of Santander, as "Juan Santander" instead of as "Juan Fulano." Still more confusing is the practice of having ducal titles of the same names as the titles of marquisates, although belonging to people in no way related to each other. The Duchess of San Carlos, for instance, is not related to the Marquis of San Carlos, and the Duke of Najera and the Marquis of Najera belong to different families.

When the great Emperor Charles the Fifth (King Charles I of Spain) returned to the Peninsula after his election as Emperor, he established the grandeeship of Spain, an institution which has exercised the most profound influence upon the life and politics of the country. He recognized twelve of the most powerful nobles as "grandees," in imitation of Charlemagne, who, after his coronation as Emperor by the Pope, created twelve peers of the Holy Roman Empire. 
I have spoken of the grandeeship as an institution rather than as a degree of nobility, because it is independent and apart from and above the usual titles of nobility. It is the most coveted honor in Spain, except, perhaps, admission to the Order of the Golden Fleece. To-day instead of twelve grandees there are about two hundred. Every duke is one, but of the thousand marquises not more than eighty, and only about seventy-five of the counts.

So independent of titles is the grandeeship that there is to-day one Spanish subject who is a grandee, although having no title of nobility, and there are two or three foreigners without Spanish titles who, nevertheless, have the grandeeship. Further, counts who are grandees far outrank marquises who are not. I knew a count (with grandeeship) who professed himself quite indifferent when created a duke, telling me that, in Spain, all that counted was the grandeeship, and that it was only in the estimation in which he would be held abroad that the new ducal title would benefit him. Yet the grandeeship does not necessarily imply ancient and distinguished lineage; for, as has been said, now and then someone previously without title is made a duke, thus becoming a grandee, or a patent of grandeeship is given to some marquis or count. Nevertheless the oldest and greatest families have this honor, and it is their proudest possession, for it gives them a rank just below the royal family. By fiction they are cousins of the King. In early days they yielded precedence to the King and his 
sons only; they claimed the right to go before foreign princes of the blood, and to-day they correspond in rank to the highest nobility of those countries having princes (not of the blood royal) or fürsten. They have no special duties, although the high personnel of the palace is generally chosen from them, and one grandee is on guard at the palace each day. They have no coronet and no insignia, but when they are Lords of the Bedchamber with exercise and service, they wear a large golden key on the back of their coat, at the hip, to symbolize their right to enter the apartments of the King.

Beyond their recognition as being next in greatness to royalty, and taking precedence of all other Spaniards, they have few prerogatives. One of these is the right to cover themselves in the presence of the King - that is, to put on their hats if he has his on; and the women who are grandees in their own right may sit in the presence of the Queen when she is seated. When persons succeed to the grandeeship, these rights are recognized in a quaint ceremony called "the covering of the grandees" and "the taking of the pillow or cushion" (almohada). The men who are thus entitled appear before the King in the palace, holding their hats in their hands. One after another they deliver addresses setting forth the valorous deeds of their ancestors which caused the grandeeship to be conferred upon them. These read, in many cases, like pages from the romance of "The Cid." As each finishes his speech the King says, "Cover yourself!" and 
forthwith the grandee puts on his hat. During my residence in Madrid eight or ten grandees covered at one ceremony, among them the British Duke of Wellington, grandson of the first and great Duke, who for his services to Spain was made Duke of Ciudad Rodrigo, the scene of one of his great victories. As heir to this title and to the grandeeship attached to it, the present Duke of Wellington, on this occasion, made a most felicitous speech, characterized by modesty and phrased in graceful language. Even more interesting is the ceremony by which women are recognized as grandees. Each takes a pillow or cushion and enters the room where the Queen is. On being presented, declaration is made of her having succeeded to the grandeeship in her own right. The Queen then says, "Seat yourself!" Taking the pillow the new grandee then sits down on it.

I have already said that not a few nobles have many titles, and of ten a half-dozen of these carry the grandeeship with them. In Spain it is common to say of such a person: "He has the right to wear six hats." On the same theory certain grandees who are women would have the right to sit down on five or six cushions.

Some of the prerogatives and privileges of the nobles are interesting in their origin. The Counts of Ribadeo annually receive, on January 6, the clothes that the King has worn on that day. These are sent from the Royal Palace to the House of these Counts, who are also Dukes of Hijar, in magnificent state carriages, and their despatch and delivery are accompanied by much cere- 
mony. This custom dates back to the year 143I. In that year one of the kings of Castile was lost while hunting. Wet through to the skin, by the pouring rain in which he had been caught, he repaired to the thatched cottage of a shepherd, who not only received him hospitably, but lodged him for the night and gave him his own dry clothes to put on. The King did not reveal who he was. When he left in the morning he asked how much he owed. The shepherd with pride answered: "You are not a Castilian if you inquire the price of hospitality." The King was so much delighted with the shepherd's high spirit that he told him he was the King and he took him back with him, created him Count of Ribadeo, and decreed that forever in the future the clothes that should be worn by the King on the anniversary of the day should be sent to the Count of Ribadeo, in recognition and remembrance of the shepherd's gift to him.

If titles are many in Spain, orders and decorations are even more numerous. Whether or not one esteems these forms of recognition, one who does not learn something of their origin and meaning, and of the great value which is attached to them, and the high honor in which they are held, overlooks something which exercises a tremendous influence upon men in all European countries, and which, in Spain as elsewhere, gives life and color and meaning to much of court life. Jean Jacques Rousseau, in his "Economie Politique," declared: "Citizens who have deserved well of their country ought to be recompensed by honors, 
never by privileges." Spain, unfortunately, has not always observed the restriction that the great political philosopher mentioned, but she has distributed honors in the shape of orders and decorations with a generous hand, although perhaps no more lavishly than some other countries.

First and greatest of all orders in Spain is the Distinguished Order of the Golden Fleece, founded at Bruges, in Belgium, by Philip the Good, Duke of Burgundy, in the year 1429. He reserved for himself and his heirs the sovereignty of the order, and it passed into the hands of the Habsburgs when Mary of Burgundy, the last of the family, married Maximilian of Austria. By descent it came to the Emperor Charles the Fifth, the King of Spain. After his abdication it was shared by the Spanish and Austrian Habsburgs. When the Bourbons came to Spain in the person of Philip $\mathrm{V}$, their right to confer the collars of the order was disputed by the Habsburgs, but it was finally conceded to them, and since that time there have virtually been two orders of this name, - one Spanish and one Austrian. In each there are about sixty members. In Spain the very great majority of them are always sovereigns or princes of royal families, there being at present not more than ten or twelve Spanish knights of the Golden Fleece who are not of the blood royal. Among them are Montero-Rios, General Azcarraga, and Field Marshal Lopez-Dominguez (now deceased), all former Prime Ministers. It is no wonder, then, that all through life Spanish politicians and statesmen, like the Argonauts of old, are in quest 
of the Golden Fleece. The insignia of the order consist of a small gold ram suspended by the middle from a gold collar with blue enamel links or medallions, which hangs about the neck of the wearer. Upon the death of a member the insignia have to be returned to the officers of the order and then the same insignia are given to someone who is chosen to fill the vacancy. The ceremony of taking the oath by a newly created Knight of the Golden Fleece and investing him with the collar takes place only in the presence of the chapter. Before the oath can be taken it is necessary that the neophyte be an armed knight. If he is not so already, the King knights him then and there. Taking a sword which has previously been blessed by the chaplain, he strikes him with it three times on the left shoulder, saying, "Do you wish to be a knight?" The candidate replies, "I do." Then the King says, "God make you then a good knight, - and the Apostle Saint Andrew." Andrew is the patron saint of the order, and for centuries it was the custom for the Knights of the Golden Fleece to attend vespers in a body on the eve of Saint Andrew's Day, and on the day itself to attend mass and afterwards to sit down at a banquet, and on the next day to attend a mass for the dead. The ritual regulated the minutest details of all these services, surrounding them with great ceremonial.

Next in importance among the orders of Spain is the Royal and Distinguished Order of Carlos III, founded in I77I, by the monarch of that name. This, like many other orders, has vari- 
ous grades; namely, - beginning at the lowest, knight or chevalier, commander, commander of designated number, knight grand cross, and knight of the collar. By the grand cross is meant the broad silk band which is worn crossed over the breast, from the right shoulder to the left hip. It is of blue and white stripes, and to the lower end is fastened a small gold cross of the order bearing an image of the Virgin and the initials of Charles III. The collar and grand cross are considered such great honors that the former is awarded only upon nomination by the Government; that is, the Ministers of the Crown in Council, while they also have a power of recommendation as to the grand cross.

The Royal Order of the Ladies of the Queen Maria Louisa was founded by her husband, King Charles IV, in 1792, as an order for women. The Queen is the head of it and has the exclusive right of nominating women for membership in it. The highest ambition of a Spanish woman of the court circle is to be a grandee or the Grand Mistress of the Robes; next to that to be one of the fifty or sixty. Ladies of the Queen, and next to that to be a member of the Order of Maria Louisa, which now embraces about one hundred and thirtyfive of the most prominent women of the nation. The insignia consist of a silk band of purple and white and purple stripes worn from the right shoulder to the left hip.

Another great Spanish order for men is that of Isabella the Catholic, founded by Ferdinand VII in 1815 , after his restoration to the throne. 
38 THE COURT OF HIS CATHOLIC MAJESTY

It has degrees like the Order of Carlos III, but has no collar. Its membership is much greater than that of Carlos III and the honor, although highly esteemed, is less prized than the other. Its grand cross is a white silk band with stripes of yellow or gold in it.

A heavy tax is levied when any of these orders is conferred upon a subject.

Besides the foregoing orders there are several created especially in recognition of military services; namely, the Order of San Fernando, the Order of San Hermenegildo, the Order of Military Merit, and the Order of Naval Merit. There is also the Civil Order of Beneficence, founded by Isabella II to reward those who have performed conspicuous acts of charity or of philanthropy.

In 1902 the present King created, in honor of his father, the Civil Order of Alfonso XII, as a memorial of the latter's interest in science and art, and as a recognition of eminent services and high attainments in these fields. Very few are the members of this young order, but one who is familiar with modern Spanish art and literature has but to glance over the list to feel that it is indeed an honor to belong to it; and if the same care in selection continue, it will constitute a group whose names will live forever; for in this little galaxy of less than fifty stars are seen such bright and shining lights as Montero-Rios, the statesman; Echegaray, the financier and dramatist, winner of the Nobel prize; Menendez $y$ Pelayo; Villegas, the great painter and director of the Prado Museum; Sorolla, the famous por- 


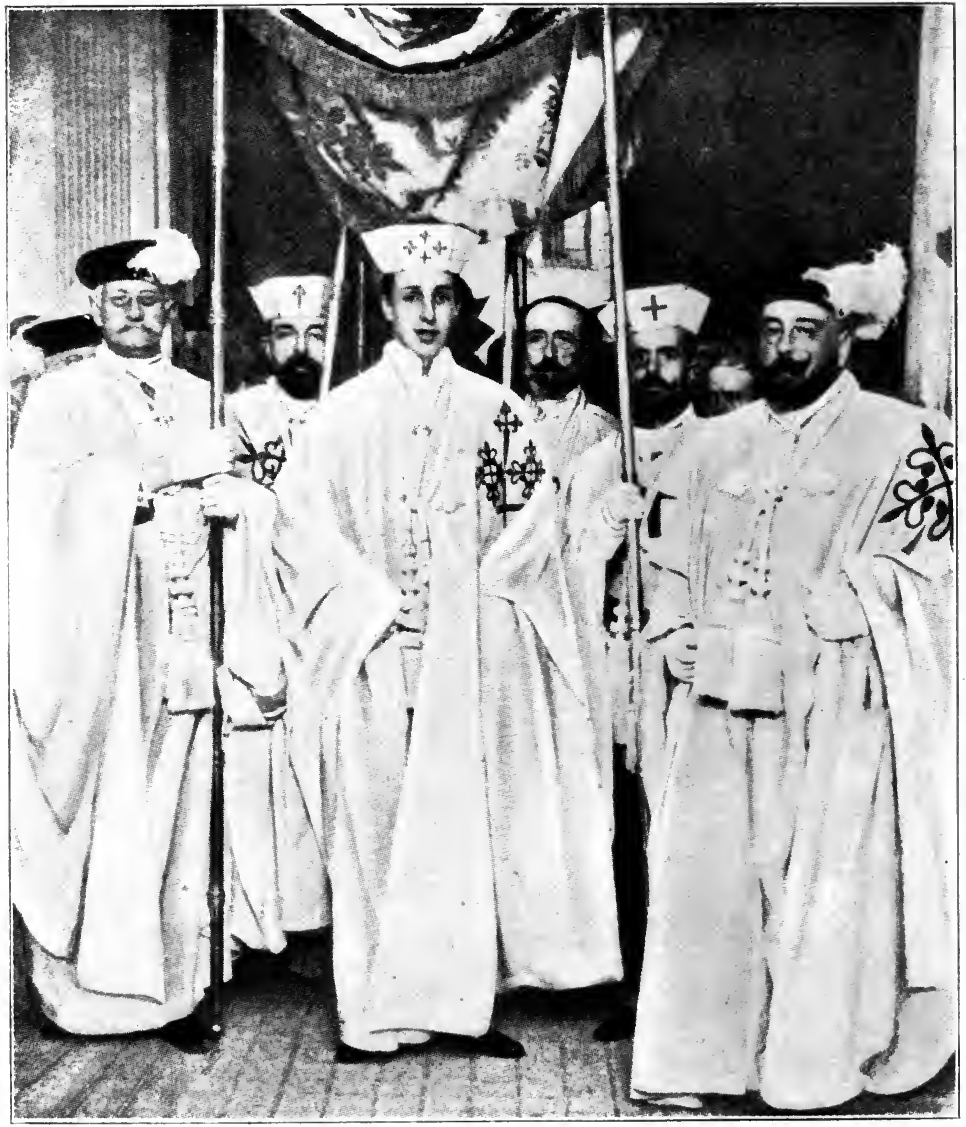

Pholo from "Nuevo Mundo"

The King as Grand Master of the Four Great Military Orders 
traitist and painter, whose trips to America have been so phenomenally successful; Moreno-Carbonero, one of the greatest of Spain's painters; Benlliure and Querol, the sculptors, and, not the least deserving, that distinguished American, $\mathrm{Mr}$. Archer Huntington, who has done so much to promote in this country a knowledge of Spain and her art.

Of a somewhat different character from these orders, but of great interest because of their mediæval origin, their perpetuation of ancient traditions and the picturesqueness of their regalia and costumes, are the four great Spanish military orders, all of which were founded in the centuries when the Spanish Christians were continuously fighting with the Moors. They were established for the purpose of protecting pilgrims on their way to the holy places, of guarding the frontier, of rescuing captives, or of waging offensive warfare against the Infidels. These are the Order of Calatrava, founded in II 58; Santiago, founded in II75; Alcántara, founded in II77, and Montesa, founded in I316. Of all these the King is Grand Master, and membership is limited to those whose ancestors were members. In the Middle Ages these orders, like the Knights Templars and the Knights of Malta, possessed very extensive properties from which their officers derived enormous revenues, and they exercised great power. To-day they are an interesting reminder of a glorious past. All of them have showy uniforms of white, much alike in general design, and all have a cloth cross sewed on the 
coat or mantle. The cross differs in form and color for each order. That of Santiago is red, pointed at the bottom like a dagger, but its top and-ends are fashioned like fleurs-de-lis. That of Calatrava is also red, but its arms are of equal length and all are fleurs-de-lis. That of Alcántara is exactly the same in form as that of Calatrava, but is green. That of Montesa is a short red Greek cross of equal arms and without any ornamentation.

Besides the ancient military orders there survive in Spain the so-called maestranzas, of which there are five: those of Ronda, Seville, Granada, Valencia, and Zaragoza. In the sixteenth and seventeenth centuries, when they were founded, these were organizations for the drilling of young noblemen in the use of arms and in horsemanship. Some member of the royal family always was, and still is, the head. In ancient days it was the duty of the maestranzas to accompany the King on his campaigns, and on days of fiesta they were not infrequently summoned to give exhibitions of horsemanship and to organize tournaments of chivalry.

In addition to orders and decorations, medals are awarded in Spain with generosity. There are medals of all kinds and for almost every occasion and for almost every form of service, - military and civic, patriotic and benevolent; medals for wars, medals for campaigns, medals for battles, medals for participation in, or attendance at, great civic events.

There is still another form in which recognition 
of merit and ability is given in Spain. It is partly official, partly private. I refer to the great academies, admission to which is restricted to a fixed and limited number, new members being elected only when there are vacancies. Absolute demonstration of capacity is required. Each person elected delivers a scholarly address or reads an elaborate thesis. In these associations are to be found the brain and the soul, the education and the culture of the nation. Election to membership in any of these is indeed an honor well worth striving for, an honor of which one may well feel proud. All the academies have their medals and badges, which the members 'wear on all state occasions. The oldest of these academies is the Royal Spanish Academy, founded in 1713, which devotes itself to the study of the language and to the preservation of its purity. It is like the Academy of France, and it contains the "Immortals" of the country. The Royal Academy of History was founded in 1738 . The Royal Academy of Fine Arts of San Fernando has four sections, - painting, sculpture, architecture, and music. There are only ten or twelve members in each section, but they are at the head of art in their respective fields. This academy was founded by Fernando VI in 1752. The Royal Academy of Moral and Political Sciences is composed of about twenty-five of the leading statesmen of the country, former Prime Ministers and party leaders. The Royal Academy of Medicine, the Royal Geographical Society, the Royal Academy of Jurisprudence and Legislation, and 
42 THE COURT OF HIS CATHOLIC MAJESTY

the Royal Academy of Exact Sciences, Physical and Natural, complete the list. Six of these academies are each authorized to elect one of their members to the Senate of the Realm, a fact which is evidence of the high consideration in which they are held. 


\section{CHAPTER III}

\section{The Presentation of Letters Credential}

70 the diplomat the most important of all ceremonies is the audience accorded to 1 him by the King to present his letters credential; for not until they have been delivered into the hands of the King himself and have been accepted by him, and the accredited diplomat thus recognized by His Majesty as Ambassador or Minister Plenipotentiary, as the case may be, is he vested with all the powers, rights, and immunities of a foreign diplomatic representative. Not until then has he any standing or recognition at the court; not until then has he any connection with the Diplomatic Corps, with whose members his relations thereafter will be like those of a family. Strictly, until received by the King, he should not call upon or be called upon by any of the representatives of other foreign countries, who in the future are to be his "dear colleagues," even though he may be obliged to wait for days or even weeks after his arrival before he can have an opportunity to present his credentials. True, even in this period of waiting he has certain privileges and rights, but they are somewhat vague and uncertain and ill-defined, 


\section{THE COURT OF HIS CATHOLIC MAJESTY}

secured to him more by courtesy and comity than by strict international law.

When the President of the United States appoints one as Minister Plenipotentiary or Ambassador to a foreign country, and that appointment is confirmed by the Senate, he issues to him a commission of office, a formal and formidable document under the great seal of the United States, signed by the President in his own hand and countersigned by the Secretary of State. This document declares that "special trust and confidence in the integrity, prudence, and ability" of the appointee being had by the President, he has by and with the advice and consent of the Senate appointed him to be Envoy Extraordinary and Minister Plenipotentiary to the country of hereby authorizing him " to do and perform all such matters and things as to said place or office do appertain, or such as may be given him in charge hereafter, and the said office to exercise and hold during the pleasure of the President of the United States for the time being." The commission constitutes the appointee's title to office. In the eyes of the American Government he is, in some respects, from that moment an American Minister. But the President's commission is not a document for use in the foreign country to which the diplomat is accredited. To evidence his right to act there, to introduce him to the sovereign of the country to which he is to go, to secure for him acceptance and recognition with all the consequent rights and privileges, he receives an autograph letter signed by the President himself 
and addressed to the sovereign, "near whom he is to reside." The form and phraseology of this letter - sometimes called the letters credential, sometimes the letter of credence, sometimes merely the credentials - vary much according to the form of government of the two sovereigns. If it is from a King to a King it will be addressed to "My dear Brother," or to "My dear Cousin," whether they are actually related or not. By fiction, all Christian monarchs are related to each other, and in fact they nearly all are more or less closely connected. But no such fiction or fact exists in the case of republics. The President of the United States and those of other republics address a monarch as "Great and Good Friend." A letter of credence reads something as follows:

\section{THEODORE ROOSEVELT,}

President of the United States of America.

To His Majesty,

Don Alfonso XIII,

King of Spain.

Great and Good Friend:

I have made choice of John Doe, one of our distinguished citizens, to reside near the Government of Your Majesty in the quality of Envoy Extraordinary and Minister Plenipotentiary of the United States of America. He is well informed of the relative interests of the two countries and of our sincere desire to cultivate to the fullest extent the friendship which has so long subsisted between us. My knowledge of his high character and ability gives me entire confidence that he will constantly endeavor to advance the interest and prosperity of both Governments, and so render himself acceptable to Your Majesty.

I therefore request Your Majesty to receive him favorably 
and to give full credence to what he shall say on the part of the United States, and to the assurances which I have charged him to convey to you of the best wishes of this Government for the prosperity of Spain.

May God have Your Majesty in His wise keeping. Your Good Friend, Theodore Roosevelt.

By the President:

RICHARD ROE, Secretary of State.

The newly accredited diplomat starts on his journey bearing this somewhat laudatory communication concerning himself. It is sealed and is to be delivered by him, sealed, to the King. $\mathrm{He}$ carries also a facsimile copy which he is to deliver to the Minister of State of the foreign Government before he is received by the King, so that the King and his Government may be apprised, in advance, of the contents of the letter.

Upon his arrival at his post the diplomat is met at the station by the Legation staff, headed by the Secretary, if he is an American diplomat, he has, in all probability, arrived at a post where the Government of the United States does not own a house for its Embassy or Legation, and he will be escorted to the hotel where he has reserved rooms, which he must occupy until such time as he can find, at his own expense, a house suitable for the official residence of the representative of one of the greatest countries of the world. The enactment, in I9II, of the law making an appropriation for the purchase of such houses will gradually correct this condition, which so long has been a humiliation and disadvantage to our Government and an inconvenience and 
injustice to our diplomats, greatly impairing the influence and prestige of the American people as well as of their representatives. How keenly this lack of a suitable residence has been felt by American ministers and ambassadors is well illustrated by the story of one of them, noted for his wit, who was accredited to the Court of St. James, and who was one day lost in one of London's impenetrable fogs and stumbled in the darkness against a cab, the driver of which called out to him: "Want a cab, sir? Want to go home, sir?" "I have no home," was the quick reply, "I am only the American Ambassador."

As soon as possible after his arrival at the foreign capital the new Minister or Ambassador, through his predecessor, if the latter has remained until the arrival of his successor (which is seldom the case and which European diplomats consider inexpedient, although it is contemplated by the American diplomatic regulations), or through the chargé d'affaires, arranges to call upon the Minister of State (Foreign Affairs) to request the fixing of the date for his reception by the King and the presentation of his letters credential. At this time he leaves the copy of these letters with the Minister of State. How well I recall that afternoon in May, 1905, when I made my diplomatic début by calling at the Ministry of State! The incumbent at that time was Señor Don Wenceslao Villaurrutia, to-day the Spanish Ambassador at London. He was a trained diplomat of "the career" and had already been his country's Ambassador to Austria. He possessed charm of 
48 THE COURT OF HIS CATHOLIC MAJESTY

manner, wide acquaintance with men, and delightful conversational powers in English and French as well as in his native Castilian. A photograph of him taken in his office hangs to-day in my house, a souvenir of a good friend and of the beginning of over four years of delightful association with the public men of Spain. As I look from time to time at that photograph of the Minister of State and his office with its furnishings and decorations, I can hardly repress a smile at the recollection of what one of my best informed colleagues told me as to the history of the portrait of Alfonso XII, so conspicuous in the background. I cannot vouch for the story, but my usually reliable informant said that this was begun by the painter as a portrait of Amadeus of Savoy, King of Spain from 1870 to 1873 ; but Amadeus abdicating, and Alfonso XII being proclaimed the following year, the head of the former was painted out and the head of Alfonso painted in its place. The same uniform would, of course, do for both, and size of body mattered little if the face were well depicted. Behold a good portrait of Alfonso XII and the painter's most realistic expression of the old cry, "The King is dead. Long live the King!" There were some who said that it was another portrait which had been so treated, and not the one in the Minister of State's office; but the story does not lose its point or its moral even if there be some question of identity.

I received word from the Introducer of Ambassadors, Count Pie de Concha, that on the fifteenth 


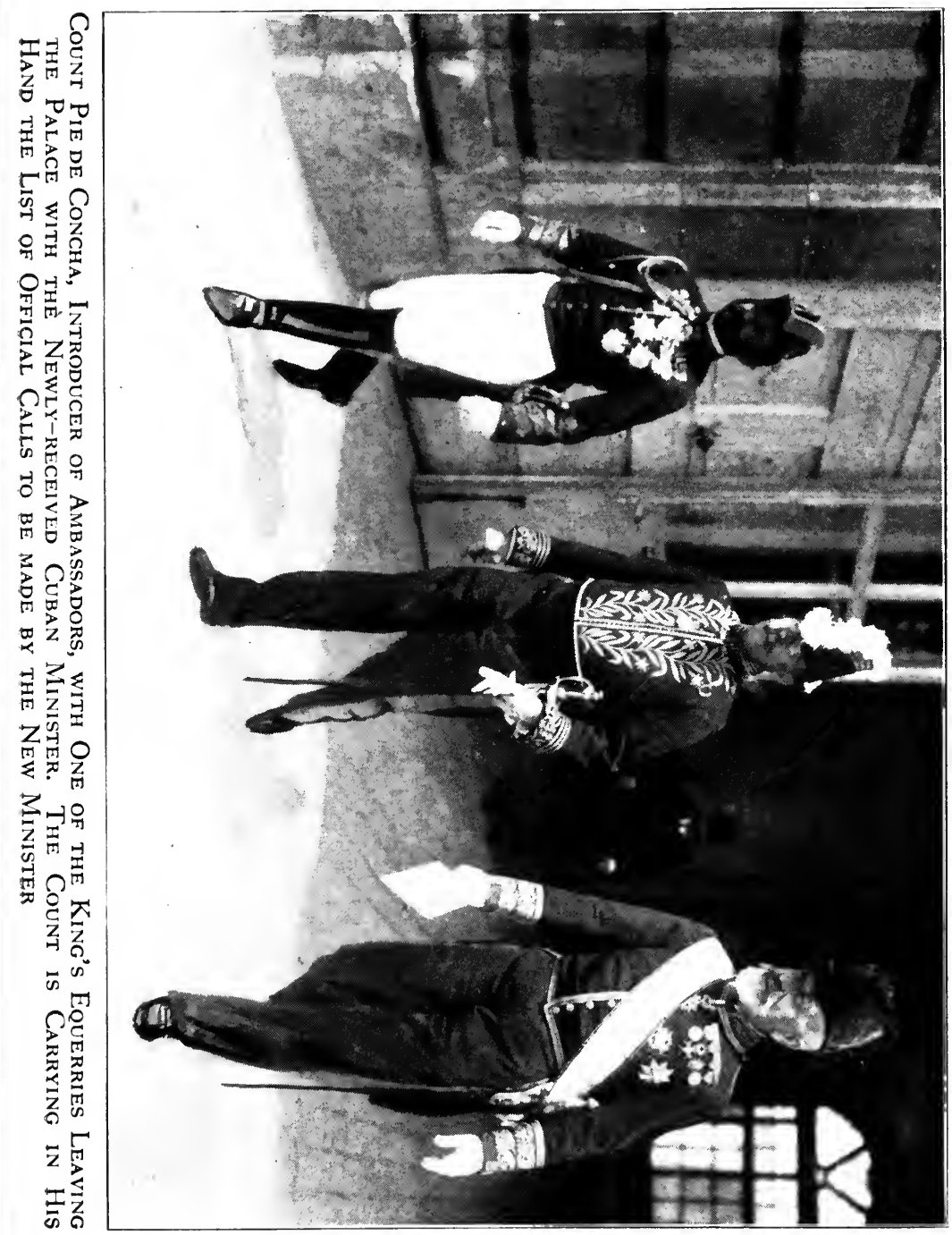




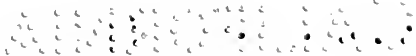


of May, at two o'clock, the King would grant me an audience to present my letters of credence. The Introducer of Ambassadors had called upon me almost the day after my arrival and had fully discharged his duty of telling me the rules and regulations and requirements relating to this audience. All the courts of Europe have at least one such official, although he is sometimes known as Master of Ceremonies. In Spain there are two. The positions are esteemed great honors and are filled by persons in the diplomatic career of the rank of Minister. Plenipotentiary. Everyone must realize how desirable is the existence of such an office, for the rules vary in different courts, and even trained diplomats must be informed as to the local usages. In a court distinguished for the formalities of its etiquette, as is that of Spain, a Master of Ceremonies or Introducer of Ambassadors is an absolute necessity. In Washington we have none. With our democratic simplicity we either need none or we need several.

When, on the day of my audience, Count Pie de Concha was ushered into my room, about a half-hour before we were due at the palace, he was magnificent in uniform. Gold braid two inches wide ran down the sides of his trousers; a number of orders were pinned to his coat, which also was braided and embroidered in gold. He carried a sword and wore the usual folding or crush hat with long plumes, so common with diplomatic uniforms. He was followed by one of the King's equerries, also handsomely uniformed, booted, and spurred. I, as well as the Secretary 
of my Legation, wore full evening dress, although it was early in the afternoon. This was in obedience to the United States statute which forbids the wearing of uniforms by its diplomats, except in the cases of officers of the regular army or of the volunteer forces in the Civil War. The State Department would not attempt, of course, to override the statute even if it disapproved it, but in the printed instructions to diplomats it remarks that the statute does not prohibit the wearing of any court dress which may be required or prescribed by the usages of a court. Many American diplomats, either because they liked the glitter and glamour of uniform, or because they disliked the prominence of a dress which made them stand out conspicuous among their colleagues, and which to an American (although not to a European) seems inappropriate for the afternoon, and which differs so little from the dress of servants that they might easily be mistaken for them, have apparently taken the liberty of construing the Department's construction and have argued that some kind of uniform was the dress required by court usage if not by court rules, and hence have adopted a uniform. Not a few have joined the state militia and wear its uniform, although strictly the statute confers the right only upon officers of the regular army or the volunteers of the Civil War.

My Secretary was anxious that I should adopt a uniform and then, of course, permit him to wear one. But I told him that while I saw no objection in principle to the wearing of uniforms 
by diplomats as well as by officers of the army or navy, and while full dress in the afternoon seemed to me incongruous, although it is the customary dress on all state occasions in Europe for those who have no uniforms, like the President of the House of Deputies of Spain, who corresponds to our Speaker of the House of Representatives, still I would not wear a uniform until the law expressly allowed uniforms. So he and $\mathrm{I}$, in our full evening dress in the afternoon, started off on our way to the palace, with Count Pie de Concha and the equerry in brilliant uniforms, and coachmen and footmen and lackeys in the most sumptuous liveries.

I had been told that carriages would be sent for us - one for my Secretary and one for mefrom the royal stables, and that they would arrive at half-past one at the Hôtel de Paris, where I was temporarily staying; for although I had taken the house of my predecessor, it was necessary to make some extensive repairs in it. But while I knew the carriages were to come from the royal stables, I was somewhat surprised when I looked out of the window and saw an admiring crowd viewing the old-fashioned state carriages which had just come up to the hotel door. They were only media-gala, that being the kind which the rules of the court declare shall be sent when the diplomat is of the rank of a Minister Plenipotentiary, and they were drawn by only two horses. Ambassadors have more resplendent carriages sent for them, and six horses draw them through the streets. But the carriages sent for me were 
quite resplendent and stately enough not only to suit me, but to draw a tremendous crowd. The Puerta del Sol, the square in which the hotel is situated, is always crowded, and it was especially so on that day, because it was the first of the days of the Romeria or annual pilgrimage to the shrine of San Isidro, the patron saint of Madrid, and thousands of peasants were in the city. The sight of state carriages seemed to please the crowd, and they stopped on the sidewalks and waited for the show to begin. The carriages were painted red and decorated with much gold. In front was a great high seat for the coachman; at the back a sort of platform where stood the two footmen. The body was swung, as it were, upon great broad straps running from the front seat to the rear platform. The horses had most showy harness, with plenty of trappings. The coachmen and footmen had powdered their hair. They wore knee breeches, red silk stockings, low shoes with enormous buckles, and long red coats with satin facings. The footmen, standing on the platform at the rear, held in their hands long canes or staves. When I went down to my carriage they opened the door and let down the steps, which, when the door was closed, folded up into the carriage. That carriage had never learned the first principles of equilibrium. Its straps or springs were so easy and pliable that the moment I put my foot on the step the carriage tipped so that I thought that I would never get in; but I did, and Count Pie de Concha got in with me. My Secretary 
rode alone in another carriage, which went first. Behind him and just ahead of my carriage rode a mounted courier, then at the left of my carriage the King's equerry, and behind it four or five grooms from the royal stables. We drove through the Puerta del Sol and along the Calle Mayor (Main Street) at the slowest of walks. Royal state carriages were not built for speed. As Count Pie de Concha spoke no English, I talked with him in Spanish, and we kept up a lively conversation, which I enjoyed much more than the gazing of the people who stood in the streets.

We entered the palace yard, passed through the Plaza de Armas, and approached the principal entrance. Servants arrayed in gorgeous liveries stood there. I was amused to see that they insisted (although it was only in accordance with the prescribed rules) that my carriage should stop at the central or largest of the three doors and that I should enter through it, but that my Secretary's carriage should stop at the smaller door at the side and he pass through that one. Side by side Count Pie de Concha and I went up the grand staircase reserved for royalties, diplomatic representatives, and very high officials, that same grand staircase which Napoleon admired so much when he came in from near-by Chamartin to spend one day in Madrid with his brother Joseph, whom he had put on the throne of Spain. Placing his hands on the heads of the marble lions which stand as guardians at its foot, the great conqueror of Europe exclaimed: "Ah, this Spain which I have so greatly desired, 


\section{THE COURT OF HIS CATHOLIC MAJESTY}

I hold it now." Mounting up to the top he turned and, surveying the splendor of the Royal Palace, said to Joseph: "Brother, you are better lodged than I." As the Introducer of Ambassadors and myself reached the landings, armed halberdiers saluted by pounding on the floor with the staves of their ancient halberds. We entered the saleta and my Secretary and I waited while Count Pie de Concha went into another one of the salons to notify the King of our arrival. In a few minutes he returned and together we passed into the antecamara, the room where Ministers Plenipotentiary are always received; for, be it known, diplomatic rules now embodied in international law require that all diplomatic representatives of the same rank shall be received with exactly the same ceremony, - the same kind of carriages, the same number of horses, servants in the same liveries, a guard of the same size and of the same character. Woe betide if there be any discrimination! I once knew a diplomat who protested to a certain Government because its sovereign did not converse with him as many minutes as he did with other foreign representatives. Oh, the littleness of great minds!

As I passed through the doors which servants flung open, and crossed the threshold, I saw in a corner of the room a dozen or more Spanish high officials, grandees, and palace functionaries, all in uniform, ranged in two lines back of a small table covered with a rich gold cloth, at the end of which was seated the King in the uniform of a captain general. He was erect, tall, dignified. 


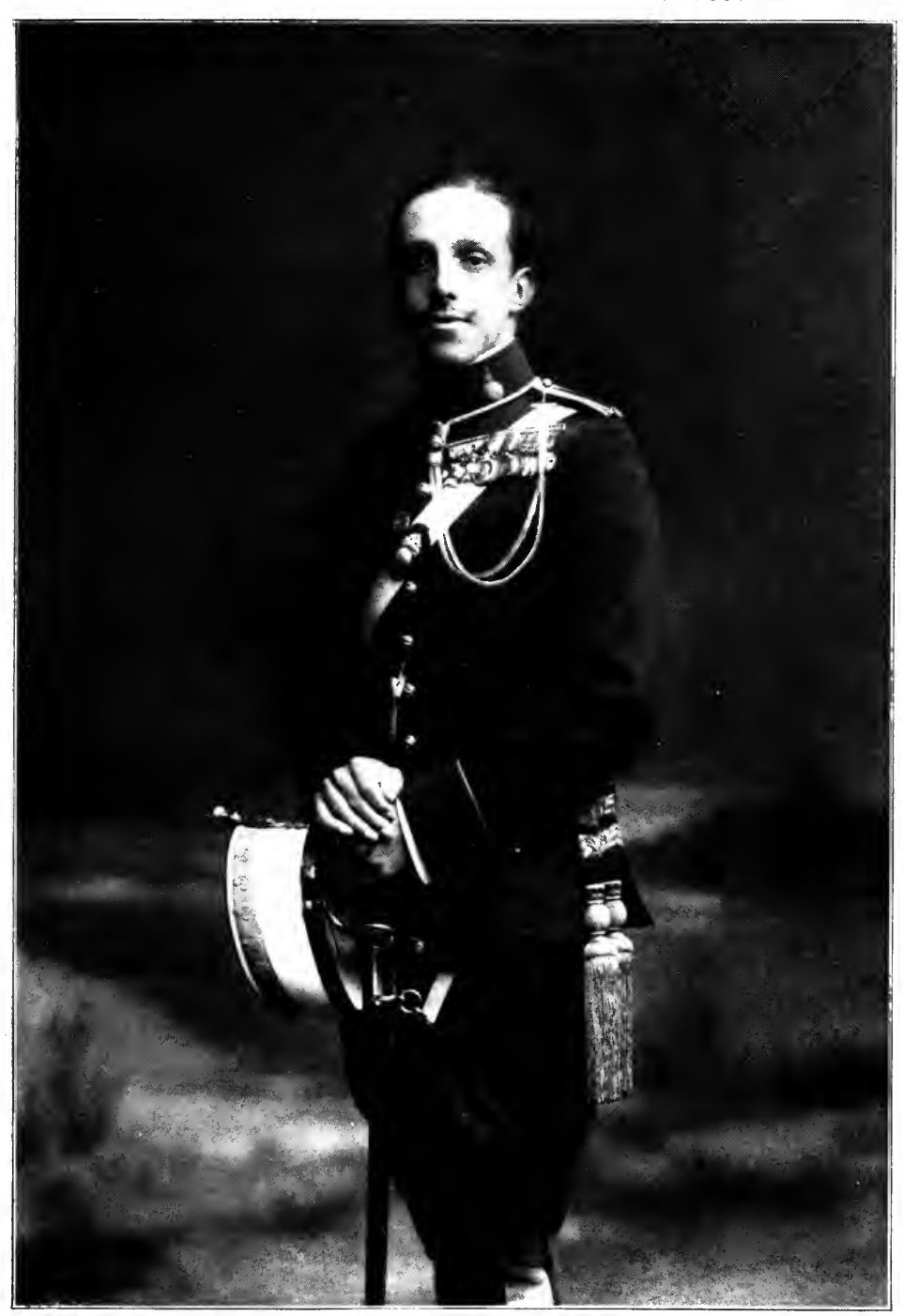

Photo by Kaulak

King Alfonso XIII in 191 I 


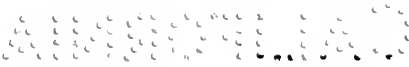


He appeared to me to have a pleasant countenance, although his face when in repose was somewhat sad. I had hardly time to take note of the surroundings or to give more than a brief glance, for my thoughts were upon compliance with the etiquette of the occasion. As we crossed the threshold the Introducer of Ambassadors said to me sotto voce, "La reverencia," and I made a bow; then I went about half way across the room and made another bow, and then approached to within a few feet of the King and made the third bow, as required. I was holding my letters credential in my hand, and it was now time to present them.

In almost every court a diplomat on presenting his letters makes a brief speech. Nearly always these discourses are cast in the same mould and express the desire of the country which is sending the diplomat to continue cordial and friendly relations with the Government to which he is accredited, a purpose which he declares he will with keenest pleasure endeavor to accomplish, and possibly he makes some allusions to longstanding friendship between the two nations, or to some other matter which might fitly proceed from the throat of the dove of peace. But in Spain the rule is that only Ambassadors make speeches when they present their letters credential. Therefore Count Pie de Concha had told me to make no speech, but merely, after my third bow, to say three or four words to the effect that I bore a letter from the President of the United States accrediting me as Minister at the Court of His Majesty, whereupon, he said, the King 
56 THE COURT OF HIS CATHOLIC MAJESTY

would rise and take it. As the instructions of our State Department require its diplomats to address the sovereigns to whom they are accredited in the language of our own country (our official letters to them also being in English), I did not think that great preparation was needed for three or four words. So speaking slowly I said: "Your Majesty, I have the honor to be the bearer of a letter to Your Majesty from the President of the United States accrediting me to Your Majesty's Court in the quality of Envoy Extraordinary and Minister Plenipotentiary." I paused a second, thinking I had given full measure for the "three or four words" which I was to speak, but as the King continued sitting, I resumed: "I am charged by the President with the very agreeable duty of expressing to Your Majesty the most cordial sentiments of good-will and friendship of the President and of the Government and of the people of the United States, and their best wishes for the prosperity and welfare of Your Majesty, of all the members of the royal family, and of the Government and people of Spain."

The King then arose, took the letter and saying that he did not speak English very well, in quite perfect English asked me the usual questions: "When did you arrive in Madrid?" "When did you leave your own country?" "Did you come directly here?" These are almost stereotyped. Everyone expects them as the first questions of the first audience, just as children in Episcopal Sunday-schools expect that the first questions put to them from the catechism will be "What is your 
PRESENTATION OF LETTERS CREDENTIAL 57

name?" Answer: "N or M." "Who gave you this name?" A brief conversation followed, in which the King expressed the hope that I would enjoy my residence in Madrid. I then presented my Secretary to him, and after a few questions His Majesty bowed and went out. One by one the dozen or more officials who had been present also bowed and went into the adjoining room. That audience was over, but the Introducer of Ambassadors informed me that I would soon be received by the Queen Mother, Maria Christina, and he escorted me in to the room where the officials had gone, the camara. There he presented me to them. He also introduced me to the Grand Mistress of the Robes (Camarera Mayor), the Duchess of San Carlos, who is his sister-in-law, and to the Duke of Sotomayor, the Grand Chamberlain, and to the Duchess of Sotomayor, who was lady in waiting on duty for that day.

I was glad to meet the Sotomayors. Not only were they one of the great families of the realm and he the head of the court, but he had some connection with the United States, his grandfather, Señor Irujo, having been one of Spain's first Ministers to the United States and having married the daughter of one of the early governors of Pennsylvania. Besides, the Sotomayors were not only a great family, but a very large one; and as I was in Spain as the representative, in a sense, of President Roosevelt, who was continually preaching against race suicide, it was quite fitting that I should form the acquaintance of such families. Both the Duke and Duchess 
58 THE COURT OF HIS CATHOLIC MAJESTY

of Sotomayor had been married before, and each had had children. There were also children by this, their second marriage. Counting "his" children, "her" children, and "their" children, as Madrid people were accustomed to speak of them, there were no less than sixteen. But in Spain, happily, large families are the rule, and I am glad to say that they always seem happy families. Sixteen is not the record, even for one mother. While I was conversing with these people, the Introducer of Ambassadors was arranging for my audience with Queen Maria Christina.

Just before I was summoned in, the Duke and Duchess of Arcos came out. He was then Spanish Ambassador at St. Petersburg and had come for an audience of farewell before returning to his post. The Duchess was an American by birth. There was a charming story often told at that time on both sides of the Atlantic about their courtship and engagement. Many years earlier he was in Washington as Secretary to the Spanish Legation. He was then untitled, plain Señor Brunetti, and with remote chance of succession to a title, but he had the character and chivalry and culture which made him a perfect gentleman. The charming and talented lady who afterwards became his wife had many suitors. The young Señor Brunetti was preferred, and they became engaged, but some obstacle prevented their marriage at that time. He was transferred from Washington to Bolivia, and then made a long career in South American posts; but the eternal troth had been plighted. Nearly 
twenty years afterwards he returned to Washington as Minister Plenipotentiary and as the holder of one of Spain's oldest ducal titles and of one of the original twelve grandeeships which the great Emperor Charles the Fifth had created. The wedding took place, and if there is a happier couple or if there are more charming people I do not know them.

The Introducer of Ambassadors ushered me into a small room just off the grand camara. My Secretary followed. We made our three bows to the Queen Mother as we had done to the King. She received us standing, as is customary at first audiences of this character. At all subsequent audiences I was invited to sit. She was dressed in black because of the death of her daughter, the Infanta Mercedes, only seven months previously. The Queen Mother is of medium height, slight, graceful, and distinguished in bearing. We waited for her to commence the conversation, as etiquette requires, and she began with the usual questions, speaking in perfect English without the slightest trace of accent. How long had I been in Madrid? When did I leave the United States? etc., etc. But she quickly widened the range of subjects, being particularly anxious to know in what countries I had travelled and seeming much interested when I had told her I was well acquainted with all the European countries except the Balkan States. She expressed the wish that her duties would give her more time for travel. She was very much interested when I told her that the year before I had taken a long 
driving trip through the Austrian Tyrol, and was enthusiastic when I told of my liking for Innsbruck, which had been her former home. She asked me if the King had spoken to me in English, saying that he was timorous about doing so, although she thought that he spoke it very well; that when he was a baby he had had an English governess. With manifest mother-pride she inquired if I was not surprised to see the King so tall. She also asked if I had met the Duke and Duchess of Arcos, and referred to the romance of their courtship, saying that it was like the story books. She also inquired what house I had taken as a residence, and when $I$ informed her that it was the one my predecessor had occupied, she said she knew it, and that she understood that it was a very good and commodious house. I then presented my Secretary, and after a few questions she extended her hand; we then bowed and backed out of the room.

The Introducer of Ambassadors accompanied us back to the Hôtel de Paris in the same carriages in which we had come to the palace, and in the same style, and with the same escort. $\mathrm{He}$ and the King's equerry came up to the door of my apartments in the hotel and then, after he had handed me a list of eighty-five official calls to make, he took leave of me. According to the letter of the rule as laid down and printed, I was obliged to call immediately upon the Prime Minister and the Minister of State, and must needs change my clothes; for this call (so says the rule, which regulates even details) must be made 
in a frock coat. Diplomatic usage in Spain also required that I call in person upon my diplomatic colleagues who were of ambassadorial rank, and that I first write them a letter soliciting the fixing by them of an hour when they would receive me. Upon all the other Spanish officials and upon my diplomatic colleagues of equal rank I' was not required to do more than leave cards, although it is both courteous and expedient to call upon them if they are at home.

1. My credentials having been presented it was my duty as well as privilege to ask for an audience with the Queen Mother at which I could present my wife, and to ask for audiences for both of us from the Infantas, and for myself from the Infante Don Carlos, the "Prince Widower" as, according to Spanish custom, he was then called. An interesting incident occurred as I finished my audience with the Infante Don Carlos. The Chief of his House, the aged Duke of Vistahermosa, former Spanish Ambassador to Russia, said, quite to my surprise: "Now, we will go and see the little Infante" (Alfonso, son of the Infante Don Carlos, who was then heir to the throne). A door was thrown open and there stood the little four-year-old Prince, who with his nurse and his aya or official governess, the Duchess of Santa Mauro, had just come in from the palace gardens. It was a touching sight to see the aged Duke bend over and kiss the hand of the little Prince. He was a strong, healthy, and beautiful child. I said a word or two to him in Spanish, after they had said to him, "This is 
a Minister," but the Duke quickly interrupted me by saying, "Oh, the Prince speaks English." Our conversation was not a long one, but I had no more pleasurable or memorable audience than that one. After these audiences, calls had to be made upon the Mayordomos of the houses of the Infantas and of the Infante, upon the ladies in waiting of the former, and upon the aides of the latter, and upon the aya of the "Infantito Alfonso." I had also to call upon the nine Ministers of the Crown, the President of the Senate, the President of the House of Deputies, the Captain General of the Region, four Captains General of the army who lived in Madrid, the Alcalde (Mayor), the Military Governor, the Civil Governor, and many others. After my wife had been presented to the Queen Mother, an official calling list was handed to her. It was about the same as mine, except that wives were substituted for husbands. Within a day or two I had distributed a good deal of card board, and a mountain of it was left in return at my Legation.

Meantime I was actually making some real and most enjoyable visits and forming the acquaintance of men whom I now am happy to number among my best friends. My first acquaintances were the Ambassadors then accredited to Madrid. They very promptly fixed dates to receive me, and I met them all before going to the palace two days later to attend the King's birthday reception. My Secretary accompanied me on all these calls. We went in frock coats because several of the Ambassadors in their notes had expressly said "The 
wearing of uniform will be dispensed with." The strict rule is that on these first calls uniform shall be worn, but so invariably is the rule waived that when it is not expressly stated, one assumes that it is waived. I shall say something about these Ambassadors upon whom I called on those days.

The Dean of the Corps was, of course, the Nuncio, for by fixed usage and by the famous rules adopted in Vienna in 1815 , the Pope's representative takes precedence, in ceremonial matters, over all other Ambassadors, no matter how much longer than he they may have been at their posts. Of the very eminent prelate and very skilful diplomat, Monsignor Rinaldini, who was then Nuncio, I shall say more in a chapter in which I shall tell of his elevation to the cardinalate and of the ceremony of imposing upon him the scarlet biretta. He occupied a great palace in an old and rather squalid part of the city, but it contained fine rooms and was well furnished. It was given to the popes as a residence for their representatives by one of the Spanish kings nearly a hundred years ago, when the quarter in which it is situated was aristocratic. Palaces of the rich in Madrid are often found in localities which now are occupied by the homes of the very poor. All their surroundings are of ten most unattractive, but within they are frequently furnished with magnificence and contain art treasures of the highest value. In 1907 Monsignor Rinaldini was succeeded by Monsignor Vico, who, in November, 19II, was made a cardinal. 
64 THE COURT OF HIS CATHOLIC MAJESTY

Oldest of all the Ambassadors in point of service was Herr von Radowitz, the German Ambassador, who had, in previous years, represented his country in the difficult and important post at Constantinople. He was also at the famous Berlin Congress when a young man, and during the years of my sojourn in Madrid he was Germany's chief delegate to the Algeciras Conference, where he was a great figure. He was a most agreeable colleague. He retired from active service in 1908 and returned to Berlin, where he died in I9I2. His country owned a fine embassy surrounded by beautiful gardens on the Paseo de Castellana, the finest avenue in the city. At that time it was the handsomest of all the embassy buildings.

The British Ambassador was Sir Arthur Nicholson, who since then has rendered great service to his country, as its Ambassador to Russia, in bringing those two nations into much closer relations, and who now is the Permanent Under Secretary of State. He was most cordial in his welcome to me and did much to make my first days - in Madrid pleasant. His Government at that time owned a very old palace near the Senate, but soon afterwards moved to another, which it bought and rebuilt, and which was situated in the Calle Fernando el Santo, two doors from where I lived. In 1906 Nicholson was succeeded by Sir Maurice de Bunsen, a most charming colleague.

The French Ambassador was Monsieur Jules Cambon (now at Berlin), whose last previous post had been at Washington, where he rendered 
PRESENTATION OF LETTERS CREDENTIAL 65

Spain and the United States great service in bringing about the cessation of hostilities and preparing the way for peace between the two countries. $\mathrm{He}$ was transferred to Berlin in 1907. The French Government owned a handsome house, which, however, lacked sufficient grounds. It was, nevertheless, one of the most beautiful of all, for it was richly furnished with the choicest products of the Gobelin looms and the Sèvres factory. During the last two years of my residence in Madrid, Monsieur Revoil was the French Ambassador.

The Austrian Ambassador was Count Welsersheimb. He had been long in the diplomatic service of his country, was stationed at Madrid for very many years, and won great fame at Algeciras. His Embassy occupied a portion of one of the old palaces in the city, - the second and third floors. It was handsomely furnished, and the Count and Countess Welsersheimb were indefatigable entertainers and the most hospitable of hosts; their Embassy was decidedly the rendezvous of society in those days, and they maintained the prestige of their country.

The Italian Ambassador was Giulio Silvestrelli. Perhaps no one in the Diplomatic Corps was so well informed as he; no one was more careful and conscientious in his diplomatic work, or more scrupulous in the fulfilment of all his obligations toward his colleagues and the offcial and social world of Madrid. I was frequently indebted to him for helpful suggestions and valuable information. 
Monsieur Schevitch, the Russian Ambassador, presented his letters of recall a few days before I presented my letters credential. I never met him. His successor was Count Cassini, who was for very many years at Washington. He had played a great role in the Orient, and at Washington was long the "grand Ambassador." In Madrid he quickly took a prominent place, although his country's interests were not very great in that section of the world. He was very kind to me, and I valued his friendship highly.

Among my many colleagues of the rank of Minister Plenipotentiary were my esteemed friends, Mariano Demaria, Roque Saenz Peña, and Dr. Eduardo Wilde, who successively represented the great Argentine Republic. In the Summer of I9II, when I made an extensive trip through South America, I had the pleasure of calling upon Señor Saenz Peña, then President of his country, an honor that would have come to him many years earlier had not his political enemies nominated his own father as his opponent and thus compelled him, in filial devotion, to withdraw. Don Agustin Edwards was the Chilean Minister. He is a young man who has already won great distinction. Now his country's representative at London, there are many of his friends who are confident that he will in the near future be President of Chile. In fact, in r9ro he came within a few votes of receiving the nomination of the dominant party. Osma, Minister of Peru, and Rendón, Minister of Ecuador, were men of 
PRESENTATION OF LETTERS CREDENTIAL 67

culture, ability, and natural diplomatic talent. Araujo Beltrão had long represented Brazil. Beistegui, the Mexican Minister, still fills that post, being almost the only one of my old colleagues now at Madrid. Two of the ablest of the younger men were Santiago Perez Triana (a Colombian, but then acting as chargé d'affaires of Salvador) and Cosme de la Torriente, who most skilfully and tactfully and successfully filled the difficult post of Minister of Cuba. Triana is now Colombian Minister at London. $\mathrm{He}$ is a writer and speaker of renown, and won fame for himself at The Hague Conference. Other colleagues of mine were Count Tovar of Portugal, Baron Reventlow of Denmark, Baron Wedel-Jarlsberg (now at Paris) of Norway, Robert Sager and Baron Strömfeld of Sweden, Señor Membreño of Honduras, and also Count Tattenbach, who succeeded Herr Radowitz as German Ambassador in 1908, Jonkheer Testa of Holland, and Baron Joostens of Belgium, Messieurs Akabane and Inagaki of Japan, and Señor José Carrera, a retired Spanish merchant who acted as Guatemalan Minister for nearly thirty years. All the last-mentioned six are now dead.

The audience which I have described in this article, for the presentation of letters credential, is that accorded in Spain to those diplomats who are of the rank of Ministers Plenipotentiary. For all such, whether they represent the United States or Siam, Japan or Chile, the ceremony is the same. But if the representative enjoys the rank known as Ambassador he is received with much 
more elaborate ceremony. His actual powers are practically no greater than those of the Minister Plenipotentiary, but by fiction he represents the person of his sovereign, and he is accorded almost the same honors upon ceremonial occasions as would be rendered to the sovereign himself. When he is to go to the Royal Palace at Madrid to present his letters credential, in addition to the courier and equerry and grooms who escort a Minister Plenipotentiary, a whole squadron of cavalry is sent. The carriages for him are full gala. One or several are furnished, as may be required for the numerous secretaries and attachés and military and naval attachés of his Embassy, and an empty carriage "of respect" drawn by six horses appears in the procession. Then come four out-riders, the mounted courier, and then the Ambassador, with the Introducer of Ambassadors, in a sixhorse carriage, with the equerry riding at the left and the captain of the escort at the right, and behind him the military escort. Troops are drawn up to receive him when he enters the palace yard, and as he passes between the files of soldiers the band plays the Royal March. The whole stairway is lined with the Royal Halberdiers when he ascends, and the Chamberlains of the Week and the Gentlemen of the House and Mouth go down to the foot of the stairs to receive him. He is escorted into the saleta, but when the King receives him, it is in the throne room, with the Prime Minister, as well as the Minister of State, besides many other officials. 
PRESENTATION OF LETTERS CREDENTIAL 69

The Ambassador reads or delivers a speech (a copy of which has previously been given to the Minister of State), and while he does so the King stands with head bared. When the ceremony is over he is escorted home in the same grand state, but he has only two calls to make. These he makes in uniform. They are on the Prime Minister and the Minister of State. The Introducer of Ambassadors accompanies him, and he is taken in a royal carriage, and then, according to the rule, "in a few minutes" these calls are returned by the Prime Minister and the Minister of State, in uniform. After that he fixes two afternoons as his reception days. Invitations are sent to all the official world, men only; for in Spain there is no obligatory reception at which the Ambassador and Ambassadress are both hosts, and there is no official reception to which ladies are invited. The invitation list is made out at the Ministry of State. The Introducer of Ambassadors makes the presentations.

After the Ambassador has been received by the King he asks for an audience of the Queen for his wife. When it is granted she must go alone, unaccompanied by him, for this is the special prerogative of an Ambassadress, and thus she is recognized in Spain as having, in a sense, a status of her own, independent of her husband. She is met at the foot of the grand stairway by the Second Introducer of Ambassadors and is escorted by him to the camara, where she is introduced to the Grand Mistress of the Robes, who then presents her to the Queen. In subsequent audi- 
70 THE COURT OF HIS CATHOLIC MAJESTY

ences she may be accompanied by her husband or may go alone.

All these formalities complied with, the diplomat is ready for the serious business of his mission. 


\section{CHAPTER IV}

\section{The Marriage of an Infanta}

$\mathrm{N}$ the twelfth day of January, 1906, the Infanta Maria Theresa, sister of King Alfonso XIII, was married in the Royal Chapel at Madrid to her cousin, Prince Fernando of Bavaria, son of Prince Ludwig Ferdinand of Bavaria and the Infanta Paz, sister of Alfonso XII. As I have said elsewhere, the Infanta Paz and her husband were also first cousins, his mother, the Infanta Amelia of Spain, having been a sister of Francis of Assisi, husband of Isabella II. Thus three successive generations of Spanish Bourbons married into the family of Wittelsbach, notwithstanding the fact that the Bourbons had generally married Bourbons. Three successive sovereigns, Ferdinand VII (first and fourth marriages), Isabella II, and Alfonso XII (first marriage), had married near relatives. Fernando VII chose as his first and fourth wives his distant cousins. His fourth wife was the niece of his first wife. Queen Isabella married her first cousin, as did her son, Alfonso XII, when he first took a wife. His oldest sister married a second cousin of the Naples branch of the Bourbon family, and his other two sisters married their first cousins. 
The wedding of the Infanta Maria Theresa was characterized by splendid ceremony, and was both preceded and followed by festivities which gave to the court a gayety to which it had long been a stranger. A grand ball was given in honor of the prospective bride by the Dowager Duchess of Bailen, one of the grandes dames of the capital, who was highly esteemed and much favored by the Queen Mother, Maria Christina, because the Duke of Bailen had been, years before, the Special Ambassador sent to the Court of Vienna to demand of the Emperor Francis Joseph the hand of Maria Christina for Alfonso XII, when he married the second time. This King and the bride he sought had been, in their youth, friends and intimates and "good comrades," but royal etiquette required that he should obtain the consent of the Emperor of Austria, the head of her house, and this he must needs do through an Ambassador and not by direct correspondence; for royalty, in its love affairs, is somewhat handicapped and, like Miles Standish, has to have its John Alden to speak for it and to obtain the needed consent.

The Duchess of Bailen's ball, like all entertainments in her house, very many of which I attended while I lived in Madrid, was marked by regal magnificence and splendor. It was the first company in a private house that the royal family had attended since the birth of the King. The Duchess's Palace of Portugalete was rich in its furnishings and its treasures of art. Its picture gallery contained one of the best private collec- 

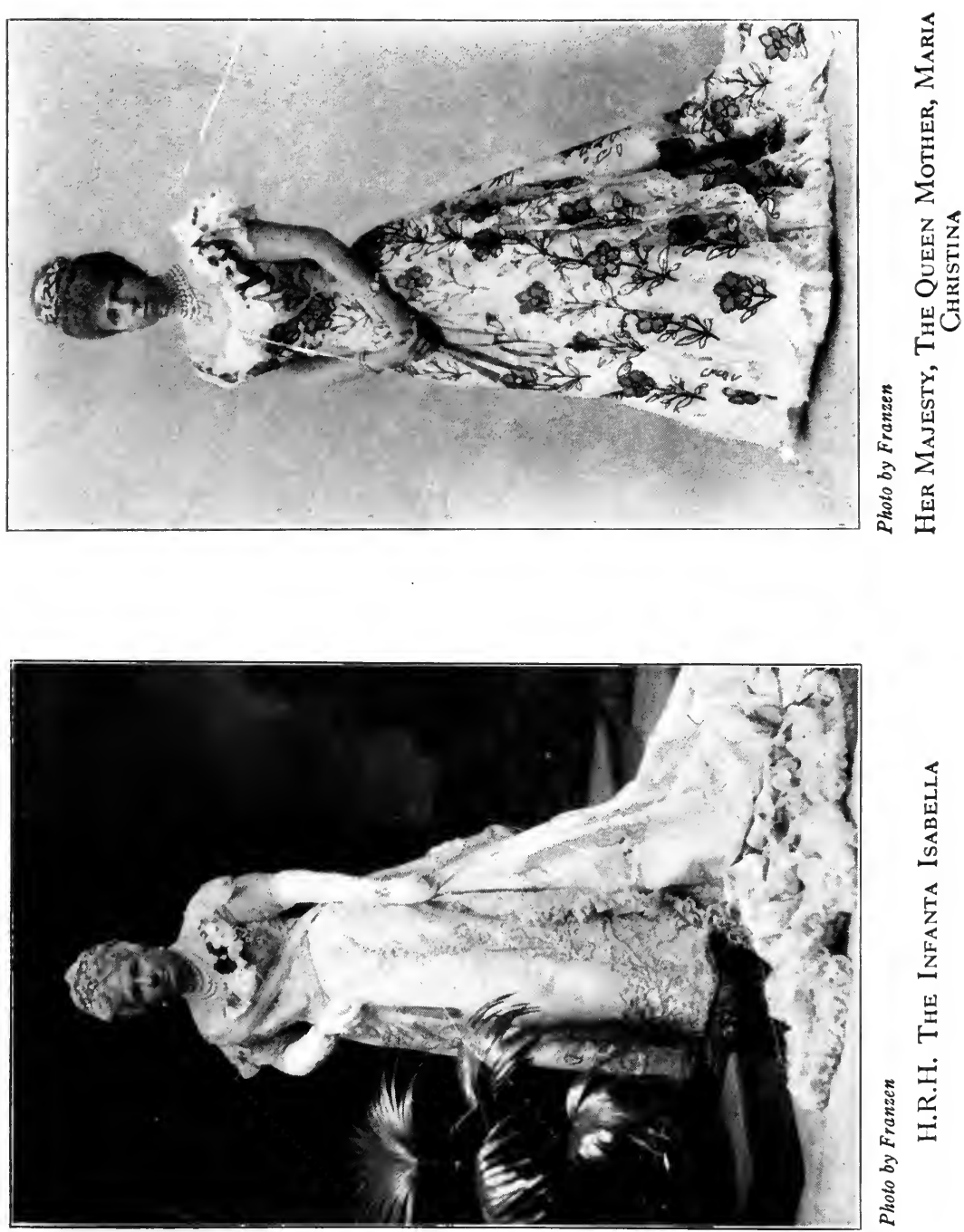
tions of modern Spanish paintings that exist. I never recall that ball without there coming to my mind a talk which I had had with the King that morning at the close of a private audience, at which I had presented to him a distinguished American scholar. I make it a rule not to repeat conversations of this character, but that which the' young sovereign said at this time shows so clearly his affability, his lack of affectation, and that rare quality which the Spaniards call simpatia, that I feel justified in making an exception.

The King said to me, "I suppose I shall see you at the ball to-night?"

"Yes, Your Majesty," I replied, "although I fear that I shall be unable to dance, as I am suffering, keenly from a severe attack of rheumatism."

" What!" he said, "you have rheumatism! Why, that is all wrong. We ought to trade. You ought not to have rheumatism, for you would like to go and dance; I ought to have your rheumatism, for then I should not have to dance. They expect me to go and dance, and I do not know how to dance."

He went, however, and did dance, and I thought he danced well. Certainly in later years he showed proficiency and apparent fondness for dancing.

Four days before the Infanta's wedding, her aunt, the Infanta Isabella, also gave a ball in her honor at her palace. There was a more than usually brilliant assemblage, for many of the princes and princesses of Bavaria and the Arch- 
duke Frederick, Maria Christina's brother, were there and gave éclat to the festivities. There was a great crowd for a palace that was not large, eight hundred guests. Splendor and elegance were attributes of this ball, but even more striking features were the Infanta Isabella's efforts to make all her guests have a good time, her success in making everyone feel at ease and free from the restraint caused by the presence of so many royal personages, her own active participation in the dancing, and her leading of the cotillion, into which she entered with youthfulness of spirit and with zest. A remarkable woman is she, unaffected, affable, sympathetic, charitable, possessing that uncommon virtue which we call common sense. Fond of entertaining, she was constantly giving balls, musicales, garden parties, and private theatricals, and she was a frequent guest at social functions in the houses of the great Spanish families and in the various embassies. She was liked by the aristocracy, a favorite of the people, the heroine of the masses, and she knew better than any other member of the royal family the feelings and opinions and intentions of this latter class; more than once, it is said, she had been able to give wise counsel to her young nephew, the King. It is not strange, therefore, that her ball was most enjoyable and most brilliant.

There was also a grand ball at the Royal Palace two days before the wedding. As many as five thousand people were invited. No such function had been given at the palace in more than 
forty years; and as I look back upon it, it does not pale in brilliance when compared with the others that I afterwards attended there. But were I to attempt to describe its magnificence, space would fail me to make even brief mention of the other festivities and of the ceremony of the wedding, which is the subject of this chapter. In another chapter I hope to tell about a ball in the Royal Palace which took place two years later, - the first at which Queen Victoria appeared in Spain, - a ball not connected with other festivities and, therefore, permitting me to describe fully its brilliant and interesting incidents. For the same reason I can do little more than make reference to another festivity in honor of Maria Theresa, - the gala performance at the Opera House, a few nights before the wedding, when that great building was packed from floor to ceiling with an invited audience representative of the official and social life of all Spain. Splendid toilettes and costly jewels were worn by the ladies, uniforms and orders and decorations by the majority of the men. Garlands of flowers festooned the boxes that ran, tier upon tier, around the building. The one in the extreme end opposite the stage and farthest from it was the royal box, reserved for the royal family and the visiting princes. They arrived at half-past nine, ascending the grand staircase to the strains of the Royal March, and upon entering their box were greeted by the vast audience, who stood up and, turning toward them, repeatedly and enthusiastically cried: "Long live the King!" "Long live 
76 THE COURT OF HIS CATHOLIC MAJESTY

the Queen Mother!” “Long live the Prince and his fiancée!" To the right of the royal box were three boxes occupied by the Diplomatic Corps; to the left were those of the ladies of the Queen. The opera was "Aïda," and it was well sung. People had, however, gone there to see and not to hear, and when the royal party, after the third act, left their box they were followed by a great portion of the audience. Although many remained for the completion of the opera, the musicians left their post, and in a short time the great opera house was empty.

The exhibition of the wedding trousseau and presents in the palace some two weeks before the wedding cannot strictly be called a festivity, but it certainly excited much interest, especially in the feminine portion of Madrid society. Columns in the newspapers were given up to a description of the dresses, the jewels, and the other presents. One paper stated that two pages would be required to give a complete list. I must leave to others the description of dresses, although I confess that I looked with special interest at the bride's dress, which, in accordance with Spanish custom, was the bridegroom's gift to her. When I saw that exquisite creation of white satin with large velvet mantle of the same color, wedding veil and trimming of Alençon lace, I suspected that, although Don Fernando had complied with the custom and had given the dress, "mere man" had not conceived that dainty thing. His Royal Highness was donor, but I felt sure he was not designer, of that dress, and I wondered how an American bride- 


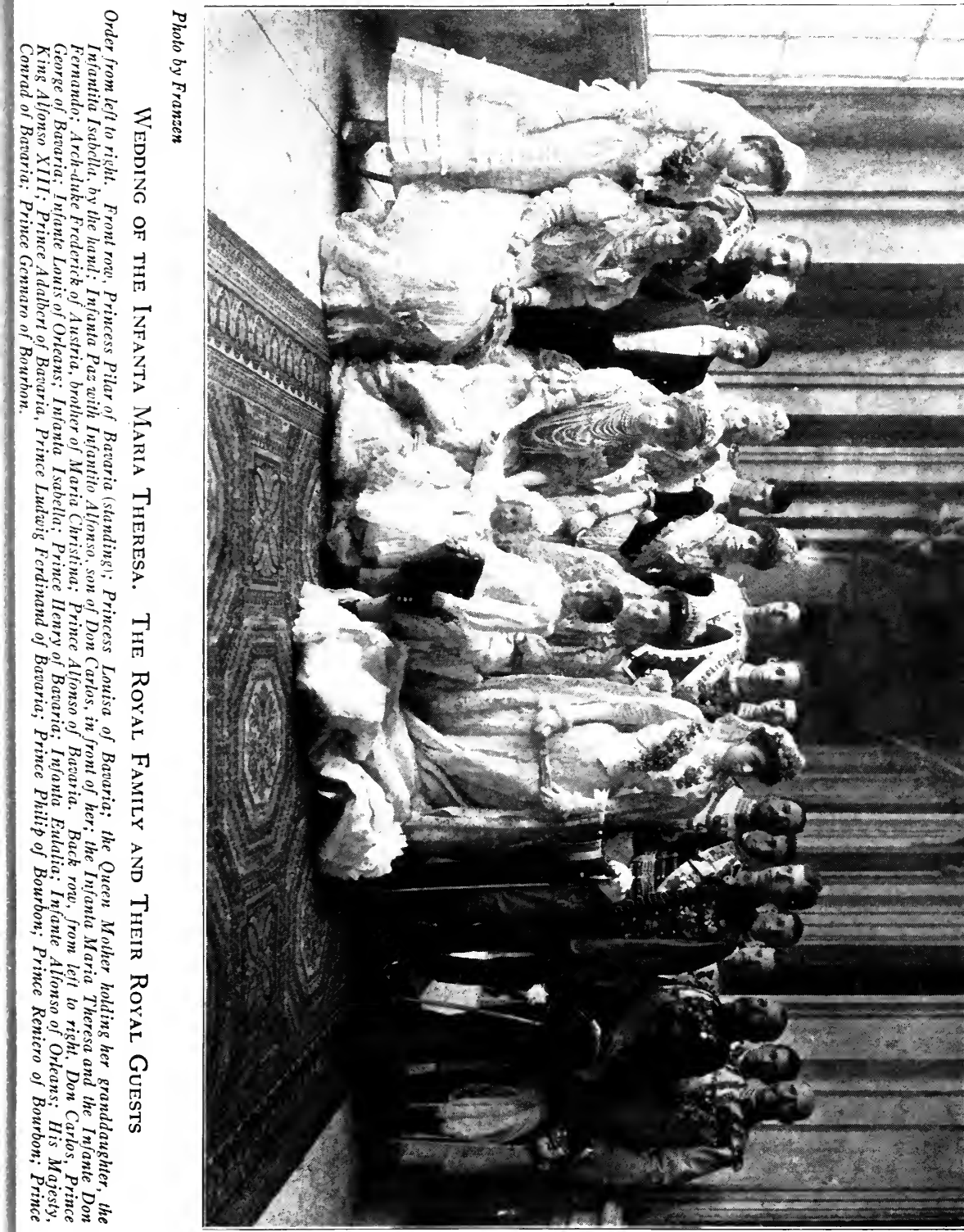




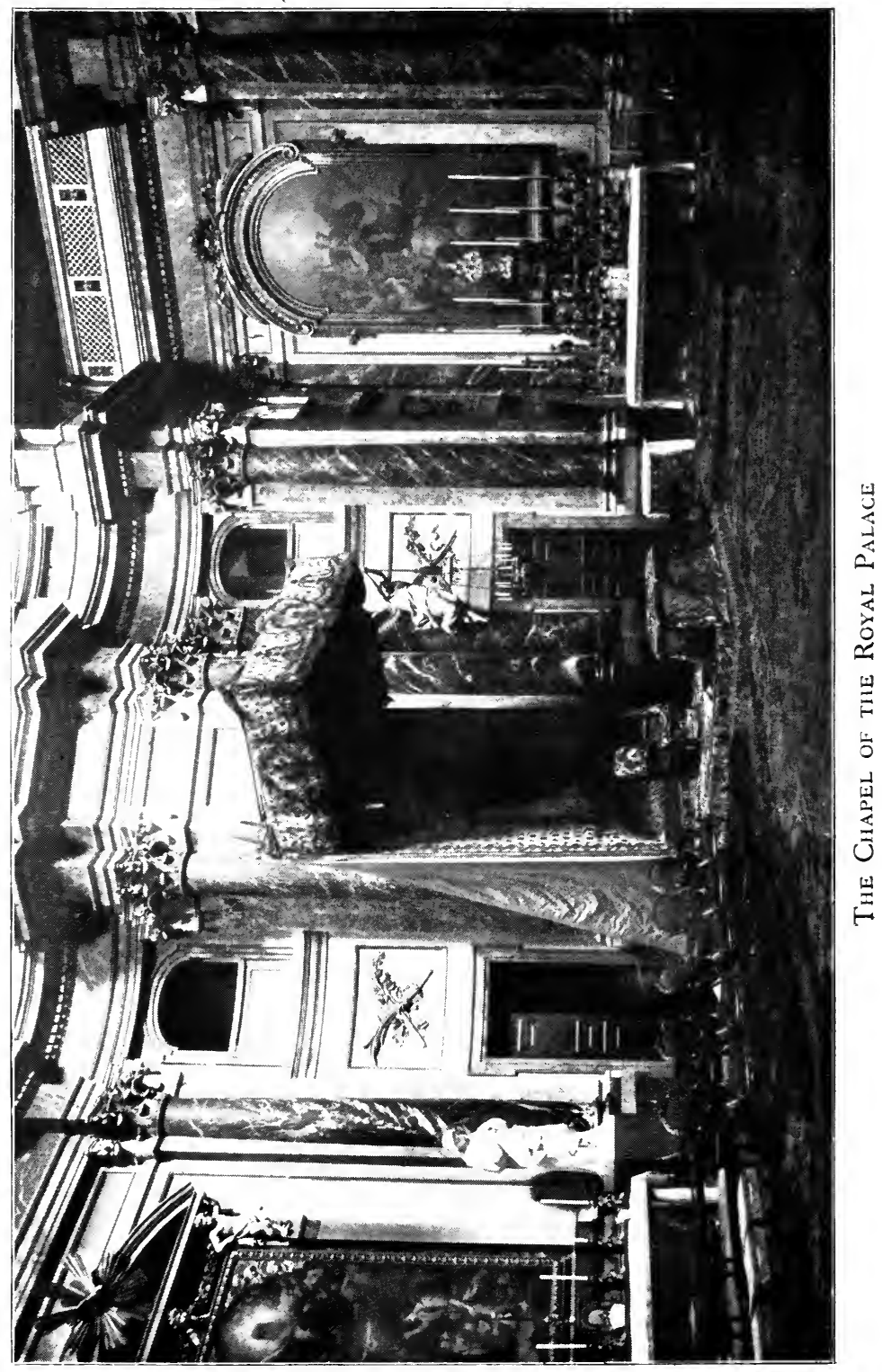


groom would get on if he were forced to select the dress for his bride. There were other magnificent dresses galore for all sorts of occasions and all kinds of functions. The splendor of the jewels which were given was dazzling. Queen Maria Christina gave a collar composed of six strings of pearls of enormous size, perfectly matched, and a pair of pearl earrings surrounded by large diamonds. All the papers declared the value of the gift was one hundred and twenty thousand dollars; and this was only one, although the most valuable, of the gifts she made to her daughter. Of course, all the other members of the royal family and hundreds of other persons also made handsome presents.

The wedding morning of the Infanta saw the great square in front of the palace, the Plaza de Oriente, crowded by the curious long before the hour of the ceremony. It was with difficulty that the carriages of the invited guests could approach the palace gates, and when the doors were thrown open to permit the entrance of those who were to be admitted to the galleries through which the wedding procession was to pass, a great wave of humanity swept in. Slight accidents occurred, and a panic was averted only by calling in a large detachment of troops to establish order. Soon the long glass-enclosed galleries on the first floor, which surround the great patio or court of the palace, two hundred and seventy feet square, and which connect the royal apartments with the Royal Chapel, were filled by eager, expectant throngs, held back toward the wall by two lines of 
halberdiers, leaving a passageway which had been richly carpeted for the wedding procession.

Ordinarily, when the court passes through this gallery to the chapel for ceremonial observances, there is only one suite for all the royal family; but on this wedding day there were two, that of the King accompanying the groom and that of the Queen Mother accompanying the bride. Ushers hurrying through the galleries announced the coming of the King and his retinue. First came mace-bearers and then the Gentlemen of the House and Mouth. Next came the Mayordomos de Semana in knee breeches, long scarlet coats, frilled shirts, and white silk stockings. Each carried a cane and also a sword. Then came the lords in waiting, grandees of Spain, covered. Four cardinals in their scarlet robes followed. Next came the Infantes of Spain and the foreign princes, all in the uniforms of their regiments or of the military orders to which they belonged. Directly after them came the King, in the uniform of Colonel of the Halberdier Guard, and by his side was the groom, Don Fernando, wearing the showy uniform of a Captain of the Hussars of Pavia, a bright red tight-fitting coat with a short furlined white topcoat, which is not usually worn, but which hangs jauntily from one shoulder. After them came the usual suite, the Palace Chiefs, the officers of the halberdiers and of the Escolta Real, and then the famous band of the halberdiers playing the Wedding March. A moment or two later the Queen Mother and the bride and their retinue passed. The Infanta, in her wedding 
dress, walked between her mother and her future mother-in-law, the Infanta Paz. The Queen Mother and all the Infantas and the foreign princesses, as well as nearly all of the long line of ladies of the Queen who followed them, wore court dresses with long trains, rich jewels, and the bands and diamond-studded decorations of the orders to which they belonged, and over their heads were the long white lace mantillas, the most graceful and becoming headdress worn in Spain. Gentlemen in waiting and Gentlemen of the House and Mouth headed the Queen Mother's retinue as well as the King's, and in it were the kings-atarms in their gorgeous scarlet dalmatics emblazoned with the royal arms. The bride entered the chapel to the strains of Mendelssohn's "A Midsummer Night's Dream." The two retinues constituted quite a pageant. In them, besides the King and the Queen Mother, were fifteen princes of the blood royal, not counting the little four-year-old Infante Alfonso, then heir to the throne, who was seated in the chapel; and there were five princesses, not including the baby sister of the little Alfonso, who was seated near him.

Fascinating was the scene within the chapel. Its dome-like ceiling, decorated by Giaquinto Corrado and supported by sixteen marble columns, in itself makes it a handsome edifice. Above its high altar hangs one of Raphael Mengs's masterpieces. On this day the chancel was filled with. white lilacs, hyacinths, carnations, and orange blossoms brought from the gardens of the 
Then occurred that which to me was one of the most interesting of the incidents of the wedding. Before answering, the Infanta arose, left the altar, went down to where her mother, Maria Christina, was sitting, kissed her hand, and asked her permission. Throughout the ceremony tears were flooding the eyes of Maria Christina. Doubtless she was thinking of the wedding in I90I of her other daughter, Mercedes, who only sixteen months ago had died.

The Infanta returned to the altar, the Cardinal's question was put to her a second time, and she answered: "I so wish."

Then the Cardinal said: "Do you consent to become the wife of the Most Serene Señor Infante Don Fernando of Bavaria and of Bourbon?"

"I so consent."

"Do you take the Most Serene Señor Infante Don Fernando of Bavaria and of Bourbon as your spouse and husband?"

"I do."

The same questions with like formality were addressed to Don Fernando. At the first question he turned to his father and obtained his consent, and then answered. Then, as the right hands of the young couple were joined, the Cardinal took his crosier in his hands and in the formula of the Church pronounced them husband and wife and gave them the nuptial benediction and sprinkled them with holy water. Thus ended the part of the ceremony which the Spaniards call los desposorios, the actual marriage.

It was immediately followed by what they call 
Cardinal Sancha, Archbishop of Toledo and Primate of Spain, officiated. Three other cardinals besides the Nuncio, and four bishops, were in the chancel or presbytery. In the hush that came over the audience, one could plainly hear the voice of the aged prelate: "Most Serene Señora Infanta Doña Maria Theresa of Bourbon and of Austria, I require Your Royal Highness, and Your Royal Highness also, Most Serene Señor Infante Don Fernando of Bavaria and of Bourbon, that if you know any impediment because of which this marriage cannot or ought not to be contracted nor be firm and legitimate; if there is between Your Royal Highnesses impediment of consanguinity, affinity, or spiritual relationship, other than that for which His Holiness may have granted dispensation; if you have made any vow of chastity or religion, or if there is any other impediment whatsoever, that Your Royal Highnesses make declaration thereof; the same command I make to all those who are here present." After a brief pause he said: "A second and a third time I require that if you know any impediment you freely declare it." Then speaking first to the Infanta because of her higher royal rank, the Cardinal said: "Most Serene Señora Infanta Doña Maria Theresa of Bourbon and of Austria, do you wish to take as your lawful spouse and husband, by words here in the presence of each other spoken, as commands the Holy Catholic and Apostolic Roman Church, the Most Serene Señor Infante Don Fernando of Bavaria and of Bourbon?" 
Then occurred that which to me was one of the most interesting of the incidents of the wedding. Before answering, the Infanta arose, left the altar, went down to where her mother, Maria Christina, was sitting, kissed her hand, and asked her permission. Throughout the ceremony tears were flooding the eyes of Maria Christina. Doubtless she was thinking of the wedding in I90I of her other daughter, Mercedes, who only sixteen months ago had died.

The Infanta returned to the altar, the Cardinal's question was put to her a second time, and she answered: "I so wish."

Then the Cardinal said: "Do you consent to become the wife of the Most Serene Señor Infante Don Fernando of Bavaria and of Bourbon?"

"I so consent."

"Do you take the Most Serene Señor Infante Don Fernando of Bavaria and of Bourbon as your spouse and husband?"

"I do."

The same questions with like formality were addressed to Don Fernando. At the first question he turned to his father and obtained his consent, and then answered. Then, as the right hands of the young couple were joined, the Cardinal took his crosier in his hands and in the formula of the Church pronounced them husband and wife and gave them the nuptial benediction and sprinkled them with holy water. Thus ended the part of the ceremony which the Spaniards call los desposorios, the actual marriage.

It was immediately followed by what they call 
las velaciones or nuptial mass, and the ceremony of the exchange of rings and the veiling and yoking of the bride and groom. The Cardinal, with his crosier in his hand and wearing his jewelled mitre, then blessed the rings and the arras, thirteen gold coins. 'Then placing one ring on the finger of Don Fernando, he gave him the other to put on the hand of the Infanta, and then he placed in his hands the thirteen gold coins, which the latter in turn put in the hands of the Infanta saying, "Wife, this ring and these coins I give you in token of marriage."

To this she replied, "And I accept them."

The coins were then placed in a tray, and the Infanta's actual ownership of them ceased, for it is the custom to give them to the servants in the Royal Chapel. With their right hands joined, the Infante and the Infanta, walking behind the Cardinal, went up to the prie-dieu, or prayer desk, placed at the steps of the altar, where they remained kneeling throughout the nuptial mass which followed.

Here it was that the Cardinal put on some of those costly vestments to which I have referred, among them the famous chasuble called the chasuble of pearls, adorned with these precious stones and embroidered in gold and colored silk. During the reading of the Epistle the Infante and the Infanta held lighted candles, and afterwards they kissed the cross which was presented to them by the Cardinal. Then followed the interesting ceremony of veiling and yoking them in sign of their union. The lady in waiting who stood behind 
84 THE COURT OF HIS CATHOLIC MAJESTY

the Infanta and the gentleman in waiting who stood behind the Infante put over the heads of Their Royal Highnesses a great veil, which was also crossed around their shoulders in the form of a double yoke. In this position they remained throughout a considerable part of the service, until the Cardinal removed it as he addressed to them the customary admonition and advice. Turning to Don Fernando, he said in closing: "A consort and companion I give unto you, not a servant. May Your Royal Highness love her as Christ loves His Church." Then to both he said: Ite in pace (Go in Peace).

Both retinues united in one as the wedding party left the chapel. The bride and groom, arm in arm, the royal family and visiting princes and princesses and the whole court, passed back through the still crowded galleries to their apartments while the Halberdiers' Band played the wedding march from "Lohengrin." Immediately the newly married couple went to the balcony of the palace overlooking the great Plaza de Oriente. The crowd of the early morning had increased. Men and boys had taken positions of vantage on the railing around the royal stables; scores had climbed the trees, and many had gotten up on those somewhat ludicrous statues of the ancient Spanish kings which once adorned the top of the palace, but which many years ago were removed for its betterment and now stand with raised arms and clenched fists, in dramatic attitude and tragic pose, around the great oval in the centre of the Plaza. Bowing and saluting the 
people, the Infante and Infanta were received with unquestionable enthusiasm and were greeted with many a viva. "All mankind loves a lover."

After this the civil inscription of the marriage took place in the Hall of Armor. The Minister of Grace and Justice, as Chief Notary of the Realm, read the long record of the marriage celebration which had been entered in a special book set apart for the royal family, and then it was signed by the newly wedded pair, the padrino, the madrina, and all the princes present down to the very youngest who could write, the Ministers of the Crown, the cardinals, and many others.

A graceful tribute was then paid by the King to his sister. Causing her and her husband to stand at the door of the apartments which they were to occupy in the palace, he, as colonel, headed the halberdiers and, sword in hand, led them at double quick through the galleries and salons, followed by the Escolta Real on foot. As they approached the Infanta, the King, with military precision, saluted with his sword, and then, taking a place at her side, he reviewed the two famous corps as they filed by.

Some of the incidents which occurred after the wedding were of interest. In the afternoon the Infanta and her husband drove to the little chapel of the Virgen de la Paloma (Virgin of the Dove) in the lower quarters of the city and prayed before the altar of this Virgin, who is regarded by the Spaniards as the special guardian of newly wedded couples, and to whom all devout couples come to pray immediately after their marriage. 
86 THE COURT OF HIS CATHOLIC MAJESTY

It is also a very ancient custom for the brides of the Spanish royal family to give their wedding dresses to the Virgin of the Atocha, and with this custom the Infanta and the others of this generation have complied.

All public and many private buildings on the day of the wedding were gay with banners and coats of arms and flags, and at night were decorated with electric lights. The usual gifts, running from a thousand to two thousand five hundred pesetas, were made to a half-dozen charities by the Queen Mother and the Infanta Paz.

Two days after the wedding a collective audience was given to the Diplomatic Corps to permit its members to express their felicitations. Much of the time of the Infante and Infanta was given up to farewell audiences granted to the foreign princes and other guests from abroad, and to going to the railway station to take leave of those persons who were of royal blood; for always when any visiting royal personage leaves Madrid, and when any member of Spain's own royal family goes away for a trip, all the other members of it and the Ministers of the Crown and the Chiefs of the Palace and the Grand Chaplain and the Nuncio go to the station to wish them bon voyage. When I was first accredited to Madrid the entire Diplomatic Corps was expected to go also, in full uniform, but this rule, so far as it affected the diplomats, was relaxed as soon as the King and the royal family began to travel frequently.

I ought not to fail to mention another festivity which occurred three days after the wedding; 
namely, the reception given in honor of the bride and groom by the Municipality of Madrid, to which the working classes of the city went in throngs. The cigarreras, women cigar-makers at the national cigar factory, of whom there are two or three thousand, and the market women, whose number is legion, attended in a body. All wore the manton de Manila, that wonderful, large, light silk shawl with woven figures and flowers of the most striking colors which the Spanish women wind about them in such an infinite variety of ways, but always with supreme grace.

The Common Council of the city, pursuant to an old custom, had announced a day or two before the wedding that one hundred pesetas, equal to about twenty dollars, would be given to every poor couple who married on the Infanta's wedding day. If the city authorities desired by this means to destroy the race of bachelors in Madrid, they made great headway. In normal times about ten or twelve marriage licenses are issued daily in Madrid. Behold the effect either of the Infanta's example or of the subsidy of twenty dollars! On that day one hundred and seventy-one licenses were issued, and the person who gave me these figures remarked: "Think of it! It was Friday, unlucky day according to the superstitious." 


\section{CHAPTER V \\ $A$ Royal Visit}

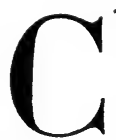

USTOM requires a newly crowned monarch to visit, as soon after his accession as to their thrones before he did, if he wishes to maintain close relations with them, and these great state visits are returned as soon as circumstances permit. In 1905 and $1906 \mathrm{King}$ Alfonso made such visits to the courts of Portugal, England, Germany, Bavaria, and Austria and to the Government of France. In October, 1905, President Loubet, and in March, 1906, Their Most Faithful Majesties, King Carlos and Queen Amelia of Portugal, were in turn the guests of the King of Spain at Madrid; while King Edward, with Queen Alexandra, visited Spanish waters in March, 1907, in their yacht, the Victoria and Albert, accompanied by a large squadron of the British navy, and at Cartagena they had a long interview with King Alfonso and accepted his hospitality on board his yacht, the Giralda. During my residence in Madrid King Frederick of Saxony was also a royal visitor to Spain.

King Edward's trip to Spain was of an exceptional character, but generally royal visits, when 
made in state, are much alike. The programme of entertainments and festivities is, with little change, the same for all such occasions. They are doubtless pleasant and agreeable to royal guest and royal host; yet after all they are much like obligatory formal calls, and I should not be surprised if happier and jollier hours were spent by kings and queens on those informal journeys when, divesting themselves of royal rank, they travel incognito, taking such titles as Baron Covadonga (frequently used by King Alfonso and his father) or Duchess of Lancaster (under which Queen Victoria of England of ten travelled). When monarchs journey without using their royal titles, they signify thereby their desire that the honors which are due to them as sovereigns, such as military salutes and guards and addresses of welcome and a thousand other wearying attentions, shall not be rendered to them. Reciprocally they free themselves from the duties of court etiquette incumbent upon them as sovereigns, particularly toward the ruler of the country in which they are travelling.

Theoretically, in these days of government through responsible ministers and of constitutional limitations upon the monarch's powers, these royal visits are mainly social in their nature. Yet beyond question they usually have large political import. Many a policy, if not formulated at these meetings, has had its origin in them, and consequently the visiting sovereign brings with him not only a large retinue of court functionaries, such as chamberlains and lords 
and ladies in waiting, but also important officials from his Ministry of Foreign Affairs. Frequently the ambassador of the king to whom the visit is made, accredited to the king who is to make the visit, is called home in order that he may participate in diplomatic negotiations that may be conducted. Further, some noble of the court which is to be visited is assigned to act as a gentleman in waiting on the visiting sovereign, and some lady of the nobility is likewise appointed as a lady in waiting upon the Queen if she accompanies her husband. Military aids, of course, come with the King from his own country, but officers of the army of the country which he visits are also detailed to him. A state visit from a sovereign means, then, the reception and entertainment of a large company.

The gentleman in waiting and the military aids usually go to the frontier to meet the royal visitors, and high officials of the court and Government, such as the Lord Chamberlain and the Minister of Public Works or the Minister of the Interior, greet them at some station before their arrival at the capital and accompany them to it. The King goes to the station to meet a royal guest who is a monarch and with him go the Infantes in full uniform; and if a queen is to be a visitor, the Queen and the Queen Mother and the Infantas also go to welcome her. The station is always decorated, covered with flags and shields and coats of arms and garlands of flowers. Certain rooms in it are specially fitted up for the reception of the visitors, and from the door of the 
railway train to the door of the carriages that are to take the party to the palace there is always stretched a bright red carpet. Soldiers are drawn up in line on the platform to render the military honors, and after the royal visitors have been greeted by the royal hosts and the presentations of the suites made, the two sovereigns always walk down the lines to review the troops. The military band is always there when the train arrives and always plays the national hymn of the visitors. If the visitor be a president of a republic his royal host will give him a hearty handshake. Such was King Alfonso's greeting to President Loubet. But if he be a sovereign of royal blood, then the fiction of kinship, whether relationship in fact exists or not, is invoked and the two sovereigns kiss each other, generally on both cheeks, as was done when the slight and youthful form of King Alfonso embraced the somewhat massive figure of his "dear brother" Carlos, King of Portugal. It is always planned that state guests visiting Madrid, no matter from what direction they come, shall arrive at the Southern Station, so that their ride to the palace may be by a long route through the principal streets, permitting a procession of imposing proportions. President Loubet, for instance, instead of alighting at the Northern Station near the palace, the usual terminus for all trains from Paris, was conducted by a tunnel, almost never used, to the Southern Station.

The reception accorded to visiting rulers by the citizens depends much upon their personal 
popularity, but even more upon the traditional relations of good friendship or the supposed community of interest between the two peoples; yet hospitality and civic pride always manifest themselves in greater or less degree. Triumphal arches are almost invariably erected in the streets, and public and private buildings are gay by day with bunting and banners and the intertwined flags of the two nations, and the portraits and monograms of the visiting sovereigns, and inscriptions of welcome, and garlands of flowers; at night all is brilliant and beautiful with electric illumination.

Monarchs draw crowds even in republics. King Alfonso's most enthusiastic receptions were always in Paris. In Madrid the streets are invariably thronged when royal visitors accompanied by the King and the Spanish royal family drive from the station to the palace. It is indeed an interesting spectacle. I will describe that at the time of the visit of the Portuguese sovereigns. Troops lined the whole route. A detachment of mounted lifeguards led the way. In a state carriage came the two Kings. King Alfonso, in compliment to his guest, wore the band of the Portuguese military orders; King Carlos, in like manner, wore the Grand Cross of the Spanish Order of Carlos III. That day the official journal, La Gaceta, published a decree by which the King of Spain, "desiring to give high proof of [his] sincere friendship and affectionate consideration for His Most Faithful Majesty," appointed him colonel of a Spanish regiment. Such is the practice among sovereigns, and not a few kings have led armies into the field 
against other armies in which theoretically they had the right to command regiments. King Carlos's uniform must have been made very promptly; for after the day of his arrival, whenever he appeared in uniform, it was in that of a Spanish colonel. The two monarchs received cheers and applause as they drove along, followed by the splendid troop of the Escolta Real. But popular enthusiasm was greater when the crowds saw the beautiful and gracious Queen Amelia of Portugal riding with Queen Maria Christina in the next carriage. Spanish chivalry permits and even exacts that, in the presence of female beauty, one be demonstrative of his admiration, and as the two Queens passed, one could hear from all sides: "Muy guapa!" "Divinamente guapa!" "Hermosisima!" ("Very beautiful!" "Divinely beautiful!" "Most beautiful!") Many were the cries of "Vivan las Reinas!" ("Long live the Queens!") The Infantas of Spain came in the next carriage, and in eight or nine carriages that followed were the suite of the royal visitors and the lords and ladies in attendance upon the Spanish sovereigns. Cannon boomed as the party entered the palace. To the strains of the Portuguese national anthem they passed up the grand staircase, on every step of which a halberdier was posted at each side.

That evening, a few hours after their arrival, the King and Queen of Portugal received the Diplomatic Corps. The men were drawn up in one long line on one side of the room, down which King Carlos was conducted by the Portuguese Minister and the Introducer of Ambassadors, 
94 THE COURT OF HIS CATHOLIC MAJESTY

each head of mission being presented in turn and having a few minutes' conversation with him. At the same time Queen Amelia was conducted down the line of ladies of the Diplomatic Corps ranged on the other side of the room. Each of them was presented to her and conversed with her. Then the King was conducted down the line of ladies and the Queen down the line of men. Such presentations are, of course, most agreeable incidents. It is an honor and a pleasure to be introduced and to have even a brief talk with those who are great because of the positions they hold, and who, to speak truly, are of ten far more great in talent and natural endowments and the elements of character than citizens of republics are accustomed to believe. In private audiences, such as all diplomats regularly have with the King and Queen of Spain several times a year, there is a somewhat extended conversation and a real opportunity to become acquainted with Their Majesties. But at general receptions of the Diplomatic Corps conversation is necessarily limited, and especially so when it must be begun by a foreign sovereign having no personal acquaintance with the diplomats, and when the subjects are limited to those which he introduces.

It is, indeed, rather hard for the visitor, and I think King Carlos found it specially so that night. He was a man of great versatility, a soldier and sailor, a painter, a sportsman, an excellent shot, a remarkable linguist. But compelled to start a conversation with persons of whose tastes and in- 


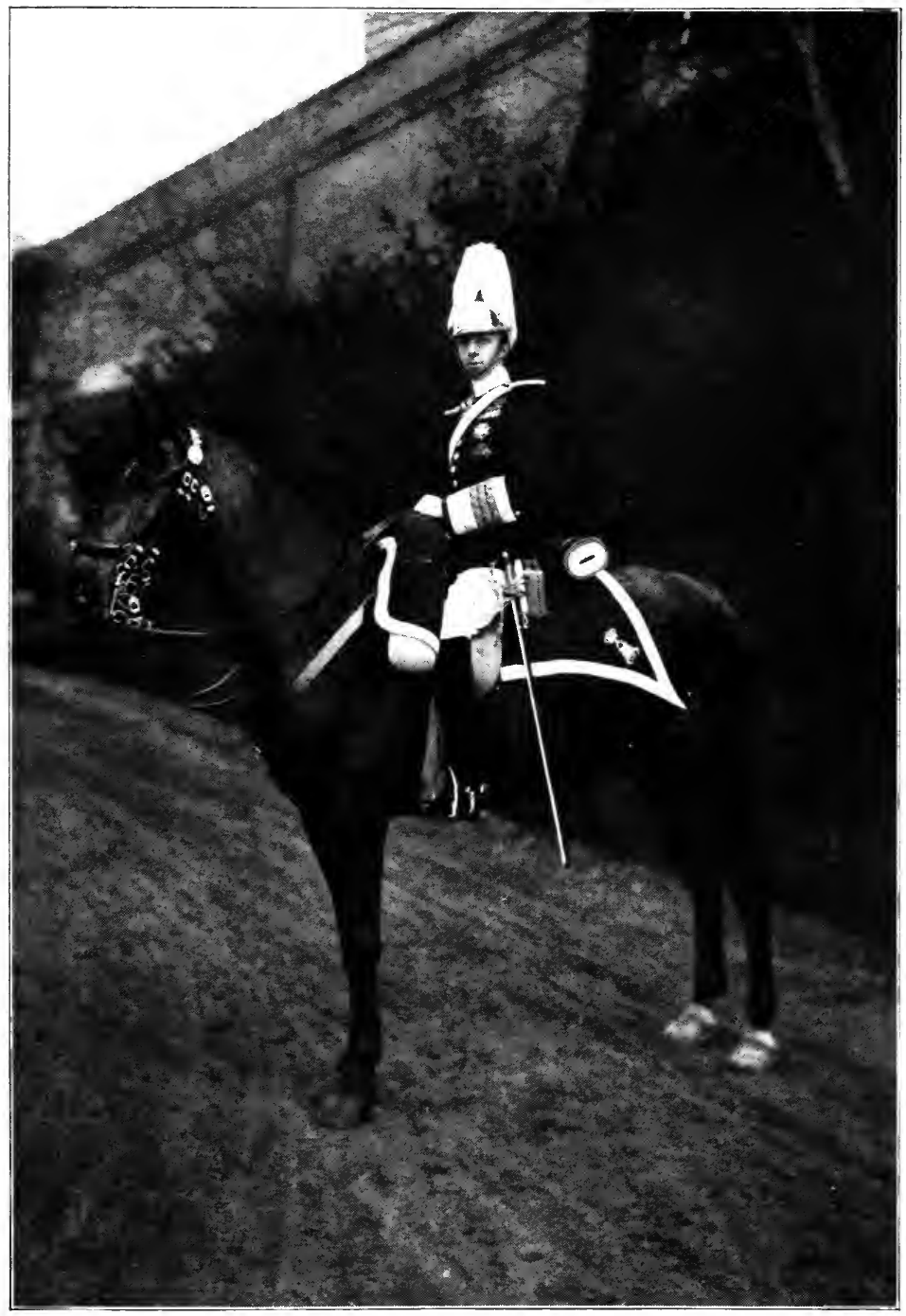

Photo by Franzen

The King in the Uniform of the Escolta Real 


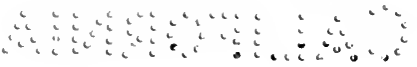


terests he knew nothing, he had a hard task and manifestly was not at ease. When Mrs. Collier was presented to him as "the wife of the American Minister," he looked up to the ceiling for an instant as if searching for a subject, and then began with: "You have a great deal of snow in your country, do you not?" This "broke the ice," to use our colloquial expression, and a delightful conversation followed. When I was presented to him he asked me if I preferred to speak in French, Spanish, or English, saying that it was all the same to him. To me it did not matter very much as long as he confined himself to that list; but had he added Portuguese, his native language, or Italian, the language of his mother, both of which languages he also spoke fluently, I should have had a hard time of it. He had no hesitation about a subject when he came to me. It was Roosevelt. Always and everywhere, everybody seemed eager to learn about him and what he was doing at the time. Much interest was also expressed by the King in the American navy. In personal appearance King Carlos was more German than Portuguese. He was of fair complexion, blue-eyed, and very stout. He had a good right to all this, for he was really German. It is unknown to many and forgotten by others that the Portuguese royal family, which so proudly boasts the name of Braganza, is Braganza only through the female line. It is to-day really the Braganza-Saxe-Coburg family, Ferdinand of the latter family having married Maria da Gloria of Braganza, Queen of Portugal, in 1836, and 
96 THE COURT OF HIS CATHOLIC MAJESTY

having become, not a prince consort, but an actual co-ruler with her.

When the diplomats were presented to Queen Amelia she was graciousness itself. She was careful to follow royalty's usual course and to ask questions, and as a rule it was only a second or two before she hit upon a subject of conversation of mutual interest. As she moved about the salon, everyone was impressed by her height. She was much taller than any of the twenty or twenty-five ladies who were present; and of all the men there were only two who were as tall as she, and they, although over six feet in height, did not seem taller. Yet so wonderfully did she hold herself, so perfect was her poise, so fine her figure, that everyone pronounced her most beautiful and queenly.

That night a banquet was given in the great state dining-room of the palace. More than one hundred covers were laid. Those who were present were the members of the royal family, the Portuguese Legation, including all its staff, and very many Spaniards of the court and Government circles. King Alfonso, in French, toasted King Carlos and expressed his desire for the continuance of the close and cordial relations between the two nations, and his hope that they might again enjoy the prosperity of the glorious days of Camoens and Cervantes. King Carlos, in no less fluent French, responded and drank to the health of the Spanish royal family and to the welfare of the "noble Spanish people."

Many who sat down at that banquet were 
wearing decorations which had just been given to them by the two sovereigns; for, according to fixed usage, it was King Alfonso's duty to bestow Spanish decorations of various orders on those constituting King Carlos's suite, and for the latter to recognize, in the same way, the services rendered to him by the high personnel of King Alfonso's court, and by those persons who were detailed or assigned to him as well as those of the Minister of State and others with whom his Ministers might negotiate. It is not necessary to be an opponent of such forms of recognition of merit to say that the work of giving them on these occasions is a most irksome and annoying duty - almost a nuisance - to the officials in the Ministry of State who must supervise the matter. There are rules as to who shall receive these honors in these cases and as to what order and decoration and what rank or degree of a particular order each shall have, but there is just enough lack of explicitness of rule, just enough room for difference of opinion as to the importance of the service rendered, just enough uncertainty as to equivalence of value of the orders of one country compared with those of the other (for it must be an equal exchange so far as possible), to leave a large field for bickering and complaining and heart-burning and gnashing of teeth. Governments have fallen because of ribbons misplaced, and jealousies between friends and comrades and colleagues have resulted, which have led straight to the duelling-ground. Indeed, it is a historical fact that not many years ago a certain 
98 THE COURT OF HIS CATHOLIC MAJESTY

Minister of the Marine in one of the European countries resigned because the ruler of a foreign country, on the occasion of his visit to its capital, gave him a certain rank in a certain order and gave a higher rank in the same order to his colleague, the Minister of War. The Minister of Marine contended that it was an insult to his country's navy, and the fact that he had received the rank which the rules required in such cases, and that the Minister of War had received a higher rank only because the lower rank had been given him previously, made no difference to the aggrieved Minister. In his opinion his own Government, in not demanding that the foreign Government give him also the higher rank in this foreign order, had permitted its navy to be insulted; and so he resigned, and the Government fell. Thus does the fate of nations hang, not on threads, but on ribbons.

Personally I recall a remarkable incident that occurred at Madrid less than eight years ago. An attaché of a certain legation was bitterly disappointed because upon the occasion of the visit of his sovereign the Spanish Government had not given him as high an order as he had expected, and he blamed his chief, the Minister Plenipotentiary, for not "making the Spanish Government give it." Such a violent quarrel ensued between the Minister and the attache that blood only would appease it, and the latter sent his resignation of his position to the Minister of Foreign Affairs of his country, so that he might be free to challenge his chief. But it takes a few days 
for resignations to be acted upon even if authorities act expeditiously, and when the resignation had been accepted and the challenge was delivered, it was declined upon the ground that the code of honor requires that one who deems himself insulted must challenge within twenty-four hours of the offence. So Madrid saw a popular young diplomat out of a post and without a ribbon on his coat and without blood on his hands.

On the morning of the second day of the visit of King Carlos and Queen Amelia, the former drove to the Embassies with his suite to leave his cards upon the Ambassadors who had called upon him; while the Queen, with her ladies in waiting, visited Madrid's famous picture galleries. At noon there was a luncheon in honor of the sovereigns at the Portuguese Legation. In the afternoon both King Carlos and King Alfonso participated in a competition for a cup offered to the winner in a live-pigeon shoot on the grounds of the club in the Casa de Campo. Both Kings qualified for the finals, and in the end King Carlos won. I did not see that contest - in fact, I never saw one; but let no one think that in that contest, in which the best shots in Spain took part, they "shot off" so as to permit the royal visitor to win. You may be sure the best man won, for kings are good sportsmen and do not esteem those who from a false sense of deference let them win; and the men with whom they contend know this fact. King Carlos was everywhere known as a good shot, and King Alfonso has also the reputation of being one of the very 
best in Spain. The latter has himself won many prizes in all forms of sport, but has lost more than he has won. I remember once attending a meeting of the Yacht Club when he was to award the prizes that had been won in a regatta. It was somewhat amusing, when he announced that a certain money prize had been won by "His Majesty, the King," to see him forthwith thrust it in his pocket. But he was a good loser as well as a good winner. I recall his telling me how anxious he was to win the cup which Commodore Clark of the Eastern Yacht Club of Marblehead gave as a souvenir of the visit of the American yachtsmen to San Sebastian in 1907. In behalf of Commodore Clark I presented the cup to the Royal Yacht Club, of which the King was honorary president. It was a beautiful gold cup. On one side of it was engraved the relief which appears on the Columbus monument at Madrid, representing Isabella the Catholic offering her jewels to defray the expense of the expedition of Columbus; on the other side was the picture of the Landing of Columbus, which hangs in the rotunda of the Capitol at Washington. King Alfonso was very desirous of gaining this cup, but although he tried many times he did not succeed.

Some kind of a hunt or shooting match is always a part of the programme for the entertainment of visiting sovereigns. It rarely is of so mild and inactive a form as a pigeon shoot. When President Loubet came to Spain, a good genuine stag hunt at Rio Frio in the Guadarrama Moun- 
tains was organized, and that elderly gentleman showed himself to be quite a Nimrod. Incidentally La Granja and Segovia and the Escorial were visited by him. A day or so later the President of the Republic was taken for some shooting in the Casa de Campo, the royal domain just outside of the city, extending all the way from the Royal Palace in Madrid to the grounds of the Pardo Palace in the country. There were a good many guns in the party, of course, but more game, although of small varieties, for one hundred and eighty partridges were shot and over two hundred and forty hares.

A gala performance at the Opera or Teatro Real is also always provided for the entertainment of state visitors, and it is a spectacle of dazzling brilliancy. The great house is invariably crowded by a most distinguished company, representative of the official world and of the society of the capital. There is always show of uniform, magnificence of dress, sparkle of jewels, beauty of face and form, animation and keen interest. The entrance of the royal personages to their box in the centre of the house at the end farthest from the stage is announced by the playing of the national hymn of the visitor. The foreign queen enters first, while the great audience, rising, cheers her. The King of Spain follows, and then the visiting king escorting the Queen of Spain, and then the other members of the royal family and the retinue of the court. Queen Amelia's beauty caused the vivas to be loud and long on the night of the gala performance in honor of the visit of 
the Portuguese sovereigns. Making a profound courtesy to the Diplomatic Corps who occupied the adjoining boxes, she then bowed repeatedly to the people in the audience, who cheered and waved their handkerchiefs. She wore a pale blue dress and, as ornaments, magnificent diamonds and sapphires. King Carlos was wearing his new uniform as a colonel of the Spanish army with the Spanish orders of the Golden Fleece and the Grand Cross of Carlos III; while King Alfonso crossed his breast with the red band of the Portuguese Order of the Christ. The plays performed were two comedies illustrative of phases of Spanish life, and so amusing were they and so well did the actors fill their roles that, to quote from one of the very staid daily papers of Madrid, "The audience committed the very grave breach of etiquette of applauding." The rigid rule of the court is that when the King and Queen are present, no one shall venture to express his opinion of the play in this way - at least not until the King or the Queen has applauded.

A royal visit without a military review would be like the play of Hamlet with the melancholy Dane left out. It is absolutely essential to the programme. In another chapter I shall tell of the Oath to the Flag and the swearing in of the recruits with its incidental review, at which King Carlos and Queen. Amelia were present. In honor of President Loubet, a grand review of all the troops of the garrison of Madrid was held at Carabanchel, six miles from the capital. It was an imposing sight and favorably impressed the 
French President. Spanish soldiers are of good material, and the army is an excellent one for its size; its record is filled with pages of heroic deeds. President Loubet was whirled out to Carabanchel from Madrid in a royal carriage drawn by a double team of four large, long-gaited Spanish mules. When King Alfonso learned of his admiration of their going capabilities, with true Spanish (or more strictly Andalusian) generosity, he sent them to Paris as a present to President Loubet.

Other forms of entertainment are provided by kings for their state guests. At the time of the visit of the Portuguese sovereigns a limited company, including the members of the Diplomatic Corps, was invited to the Royal Palace for a musicale. It was a social function of great elegance. It had the charm of not being crowded, as are the grand fettes in the palace, and with more ease and leisure could one, before the musicale, move about in the vast salons where the guests assembled, examining the works of art and other treasures of the royal residence. As a musicale, too, it was of the highest excellence, judged by art standards. The most eminent Spanish composers rendered their own selections. The distinguished company that had been invited had all arrived before the appointed hour, half-past nine o'clock. The clapping of hands by the Mayordomos announced that the royal family and their guests were passing through the salons, leading the way to the grand state dining-room where the concert was to be given. Seats had 
IO4 THE COURT OF HIS CATHOLIC MAJESTY

been placed here for all. The royal personages were in the first row, nearest the musicians, in large gilded armchairs. The uncertainties of life are so strikingly, so piteously shown by the contrast between conditions existing that night and those that afterwards developed that I cannot forbear quoting from the account of that joyful entertainment written for El Imparcial of Madrid and published the next morning:

"The two Queens were seated together in the large armchairs which had been placed for them, and the eyes of everyone were directed toward them, and everyone was feeling in them the most sympathetic interest. Tall, graceful, smiling, she who has hardly known anything but the good fortune and the happiness of life, the beautiful sovereign of Portugal, wore a very handsome gown of salmon-colored velvet, and as ornaments a diadem and collar of diamonds; and over her breast was crossed the purple and white band of the Order of Maria Louisa.

"Elegant, distinguished, veiling with an amiable smile the melancholy which past sorrows have left imprinted upon her countenance, the Queen Mother of Spain, Maria Christina, who has seen the sky of her fortune darkened by so many sorrowful clouds, was wearing with supreme elegance a gown of brocade, pale mauve in color, and over it a band of three colors, blue, red, and purple, being those of the three Portuguese orders of San Benito, the Christ, and Santiago. Her jewels were of a magnificence inexpressible, - a diadem of diamonds, Empire style; a collar of several strings of very large diamonds, and a brooch, as artistic as sumptuous, of the same stones."

Sorrow had, indeed, tried the soul of Maria Christina, but the years that were to come were to bring sunshine. In the constantly increasing influence of the King, her son, for whom she had 
lived and worked so hard; in his happy marriage; in the birth of many healthy and vigorous grandchildren, children of the King and children of her daughter Maria Theresa; in the growth and development of her other grandchildren, children of her deceased daughter Mercedes, and in the ever-increasing and ever-deepening admiration and esteem of the whole world for herself as a mother and as a woman and as a queen, she must find happiness to compensate her for much of the sadness of the years gone by. It was substantially true that up to that night Queen Amelia had known little but life's good fortune. But in the few years that have flown by since then, the bitter cup has been pressed to her lips and she has had to drink its very dregs. In less than two years her husband and her elder son, a fair-haired, sweet-faced boy, were shot dead by her side as she rode with them through the streets of Lisbon. She defended herself and her younger son, fighting off the assassins with the bouquets of flowers which she carried in her hands. Less than two years after that tragic occurrence, with that son who had become King and with all the other members of the royal family, she was compelled to flee, without a friend, a helper, or a supporter, - with scarcely a servant to aid her, - from the country over which the Braganzas had ruled for centuries, and to-day she lives in a foreign land with that son dethroned and exiled.

A banquet given by the Ayuntamiento (Common Council of the City) in honor of the royal and state visitors is almost invariably a feature 
of the entertainment provided for them. Both the President of France and the King of Portugal were so honored in Madrid, and stately and imposing were these functions. The city hall was splendidly decorated. The royal guests were met at the entrance of the building by the city officials, and preceded by the mace-bearers they were escorted to the banqueting hall. The long table shone with the splendid service of the municipality. The best bands discoursed music throughout the evening; the Alcalde (Mayor) and others made most complimentary speeches, and the distinguished guests made appropriate responses.

Royal visits are necessarily short, and programmes for royal entertainment are therefore crowded. Every day sees many functions of different kinds. The banquet of the Ayuntamiento for King Carlos was no sooner over than he and Queen Amelia had to go to an afternoon theatrical performance in the little private theatre in the palace of the Infanta Isabella, and to leave there so as to take their departure from Madrid for Lisbon at six o'clock. It must be remembered that monarchs have not the same freedom and facilities for catching trains as have common mortals who may hurry or even run, for the monarchs must go in dignity and in state. With the same pomp and with the same pageantry, between lines of troops guarding the way and amidst cheering crowds, the Portuguese sovereigns, accompanied by all the members of the royal family of Spain and the court retinue, went from the palace to the station. There, while soldiers were rendering 
to them the usual military honors, and while cannon were booming out the last salutes and bands were playing the Portuguese national anthem, King Carlos and Queen Amelia, in the presence of many diplomats and Government officials, said good-bye to their royal hosts and entered the train. The royal visit was ended. 


\section{CHAPTER VI}

\section{The Oath to the Flag}

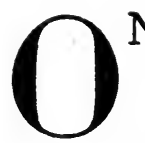

NCE a year, usually in the month of March, when Spring reigns in Madrid, the inhabitants of that "imperial, crowned, very noble, very loyal, and very heroic" city to give it the title which was formally conferred upon it long ago - witness a solemn religious service in the open air, a picturesque and almost unique ceremony, and a military review, which never fail to attract tens of thousands. It is the Oath to the Flag, the swearing in of the recruits.

To obtain a clear idea of this ceremony and pageant, the reader ought to know that Madrid from its northern to its southern limit is bisected by a series of broad streets forming practically one continuous avenue, but with different names for different sections. It has really the width of several streets. In the centre is a wide asphalted drive reserved for private carriages and automobiles. On each side is a broad, shady promenade, a veritable small wooded park, and at the extreme sides are paved driveways of the width of average city streets, along which pass the street cars and the heavy traffic. In many respects one is reminded of the Champs. Elysees 
of Paris. At various points streets intersect this broad avenue and form squares or circles adorned with monuments of high artistic merit. At the extreme northern end is situated the equestrian statue of the great Isabella the Catholic, her horse led by the bridle by a monk, with a book in his hand, and by a warrior, symbols of Isabella's interest in the Church and of her active and zealous participation in the wars for the reconquest of Spain from the Moors, which ended when she with her husband, on January 2, I492, rode in triumph into the Alhambra of Granada. The section of this great bisecting avenue which runs south from the Isabella monument about three-quarters of a mile to the beautiful monument of Columbus is called the Paseo de Castellana. Halfway along the Paseo, between the two monuments just mentioned; is a square called the Plaza del Obelisco, because in it formerly stood a small modern obelisk, replaced a few years ago by a splendid statue of Emilio Castelar, one of the Presidents of the short-lived Spanish Republic of 1873 and 1874 , and then, as now, honored and admired by all Spaniards as the most gifted orator who ever spoke in the Castilian tongue. About halfway between this monument and that of Isabella the Catholic is the equestrian statue of General Concha, Marques del Duero, a Spanish general who lost his life in battle a number of years ago.

The second section of the broad bisecting avenue is called the Paseo de los Recoletos. It is about a half-mile long and extends from the 
IIO THE COURT OF HIS CATHOLIC MAJESTY

Columbus monument to the fountain of Cybele, a handsome piece of statuary representing the ancient goddess sitting majestically in a chariot drawn by lions. From here for nearly a mile south to the Ministry of Fomento extend the sections known as the Salon del Prado and the Paseo del Prado, the former bright with flowers and thickly planted with palms and shrubs, and bordered by the magnificent buildings of the Bank of Spain, the New Post Office, the Ritz Hotel, and the Prado Museum; the latter shaded with trees and bounded on one side by the Botanical Garden.

The Paseo de Castellana and the Paseo de los Recoletos are the scenes of special interest on this day of the Oath to the Flag, and the Plaza del Marques del Duero is the focal point. Early in the morning troops of all arms of the service pass up these avenues to the sounds of military music. Some are detailed to guard the way, both sides of both paseos throughout their length being lined by soldiers; but the great mass of the troops march up past the Castelar monument and take positions assigned them between it and the monument of Isabella the Catholic. Tens of thousands of people crowd the sidewalks and the little parks that border the two paseos. Hundreds of carriages are lined up in the narrow paved streets on either side of the broad central drive. They are crowded by occupants who, in their eagerness to see everything, are standing. In the Plaza del Marques del Duero an altar has been erected for the occasion. Around it are palms. 
Upon it one sees the image of San Fernando, Spain's warrior saint, who, in mediæval times, took Seville from the Moors. Back of it are trophies of arms. On the ground at either side are cannons. Above it is a handsome velvet canopy, and in front is the purple pennant of the ancient kingdom of Castile. Near the side are stationed the retired officers of the army and the Red Cross service.

The flags and standards of the regiments are placed in a long line running parallel to the lines in which the recruits have been drawn up. At the right and left of the flags a major and an adjutant of each regiment stand as guards of honor; while a captain and two sergeants form guards for each standard. Between the lines formed by the flags and the recruits the Military Governor of the province takes his place.

Facing the altar, in the centre of the square, a temporary pavilion has been erected for the royal family. It is adorned with garlands of flowers and with laurel, and above it waves the red and yellow flag of Spain. Within, handsome tapestries cover its walls, and from the balustrade that runs along its front hang rich coverings embroidered with the national coat of arms. At the foot halberdiers in quaint uniform stand guard.

Such is always the stage set for the ceremony of the Oath to the Flag. I saw this spectacle with interest four times. In 1906 it occurred simultaneously with the visit of the Portuguese sovereigns, King Carlos and Queen Amelia, and 
II THE COURT OF HIS CATHOLIC MAJESTY

they were conspicuous figures and active participants in it. In 1908 it coincided with the visit of the Grand Duke Boris, cousin of the Czar of Russia, who, with a suite of aids, had come to Madrid as the bearer of the uniform of a Russian regiment, of which the Czar had made King Alfonso colonel; for, be it known, in such cases uniforms must be delivered with the greatest formality, and an extraordinary mission, headed usually by some member of the royal family, must be despatched. King Alfonso sent his brotherin-law, the Infante Don Fernando, to Russia, when he returned the Czar's compliment and made the latter a colonel in the Spanish army. There was little difference in the service and the review on the four occasions when I saw them, and my description, although narrating some special incidents that occurred at the time of the visit of the Portuguese sovereigns, will give a sufficiently clear idea of them all.

About ten o'clock the crowds on the sidewalks suddenly became excited and rushed for park benches and seats and other points of vantage from which they could look over the heads of the soldiers who were lining the way. A brilliant cavalcade was approaching. At its head rode, side by side, the young King of Spain, tall, slight, firm and graceful in the saddle, and King Carlos of Portugal, very large and heavy, but riding well and making a fine appearance in the uniform of a Spanish colonel. Back of them rode the general staff, and with them the Minister of War, who, in Spain, unlike the United States, is always a 


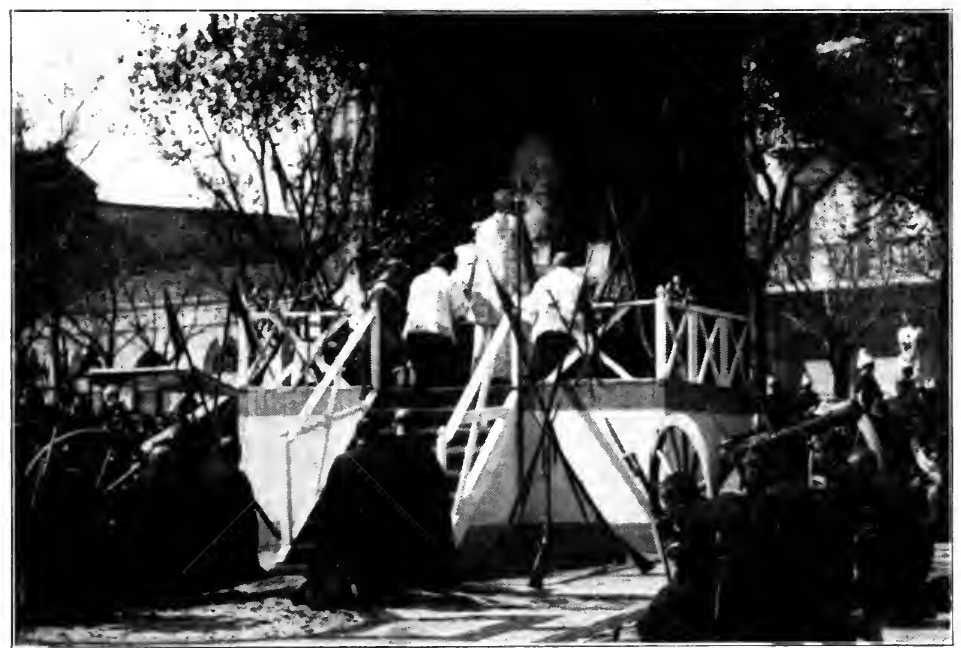

The Altar Erected in the Street

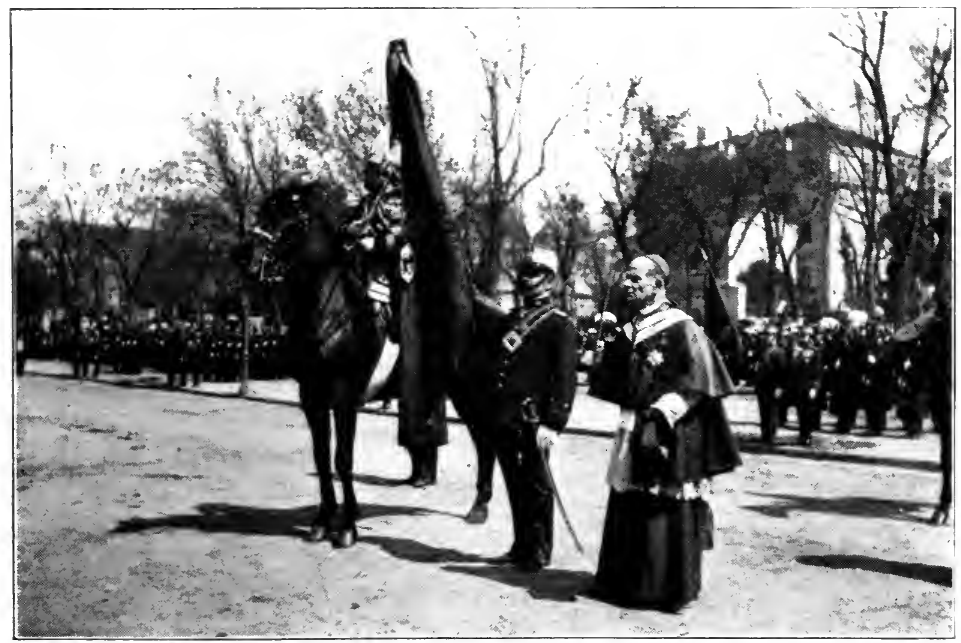

The Military Governor and The Bishop of Zion during the Reading of the Oath to the Recruits 


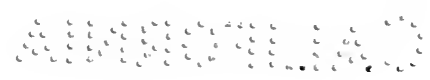


general of the army and never a civilian. The Captain General, the aids of the two Kings, and most showily uniformed of all, the military attachés of the Embassies and Legations, were also in the party. Behind this cavalcade, in carriages, came, first, the Queen Mother, Maria Christina, with Queen Amelia of Portugal; next the Infantas, and then, in six carriages, the ladies in waiting and gentlemen in attendance upon the two Queens and the Infantas. When they arrived at the Royal Pavilion and alighted from the carriages the band played the Portuguese hymn as a compliment to the national guests. The Prime Minister and the other Ministers of the Crown, in full uniform, the presidents of the Senate and House of Deputies, the Governor of the Province, and the Mayor of the city received the ladies of the royal party, followed them up the few steps leading to the tribune, and remained standing behind them throughout the service.

Mass was then begun, the army chaplains officiating, while the Bishop of Zion, Pro-Capellan of the King, knelt beside the altar throughout the service. A detachment of sappers and miners formed a guard of honor at the altar. A solemn and interesting moment in the service was that when the Host was elevated and all the troops lowered their arms, and it was an impressive sight to see the thousands kneeling upon the stonepaved streets in the acts of solemn religion. When the mass was finished the Bishop of Zion as Chaplain General of the Army, accompanied by a soldier carrying the purple pennant of Castile, the 
II4 THE COURT OF HIS CATHOLIC MAJESTY standard of the regiment known as the "King's Own," went over and stood beside the Military Governor. The oath to be taken by the recruits was then read, as well as certain provisions of the manual relating to soldiers' duties. The bands then began to play the march, and one by one the recruits, in single files, marched beneath the arches formed by the crossing of the swords of the majors with the flags of the regiments, taking off their caps as they passed under and kissing the colors.

When this ceremony had been finished the Queens and the Infantas entered their carriages and, with their suites in carriages following them, amid applause and vivas drove rapidly from this pavilion where they had attended the service to another farther down the avenue at the corner of the Calle Fernando el Santo, near the American Legation, and not far from the Columbus monument. At the side of the carriage in which the two Queens were, King Carlos rode on horseback as an escort. In this pavilion the royal ladies took seats, and the persons who formed their suites and the Ministers of the Crown took places behind them. Instantly the royal ensign, the purple pennant of Castile, was hoisted above them on a flagstaff wound with the national colors, red and yellow. From this pavilion they were to behold the march-past of the troops.

There was a murmur of excitement in the great throng, and then to its intense delight there came in sight the splendidly uniformed and mounted Escolta Real in white uniforms, bur- 
nished cuirasses gleaming in the sun, and long black horse-hair plumes (crinières) floating from the tops of their silvered helmets down over their shoulders. Then came King Alfonso, in the uniform of a captain-general, riding a great chestnut charger, followed by the general staff, his aids, and the military attachés. Arriving in front of the pavilion where the royal family and their guests were, he made a military salute with his sword, which King Carlos acknowledged in like manner, while the ladies of the royal family, rising, made low courtèsies. King Alfonso thereupon reined his horse up to a point a little in front and to the right of the pavilion and at the side of King Carlos, and remained there while all the thousands of troops filed by. The general staff took a position at the left side of the pavilion, and the Escolta Real drew up on the opposite side of the street, facing the two Kings.

The infantry came along at quick-step. Spanish soldiers always march quickly. At the head of each regiment was its band, which, as soon as it arrived at the pavilion, formed at the side of the street and played while its regiment passed, and then fell in behind it. The recruits, without arms, brought up the rears of their respective companies. Whenever the regimental flag passed, the two Kings saluted in military fashion, the Queens and Infantas rose and made low courtesies, and the colors were then dipped in honor of the Kings. Much. interest was manifested when the Infante Don Carlos, brother-in-law of the King, passed at the head of his brigade, and when 
II6 THE COURT OF HIS CATHOLIC MAJESTY the Infante Don Fernando, who only a few weeks before had married the Infanta Maria Theresa, came along with his company in the regiment of the Hussars of Pavia.

All branches of the service were represented in that review, infantry, cavalry, artillery, heavy as well as light, sanitary corps, engineers, sappers and miners, etc. - about twenty thousand in all. There was variety of uniform and there was constant but changing interest. After the infantry had passed, the mounted artillery at a quick trot came rattling down, and then the cavalry charged by with thundering noise. It was a really inspiring sight.

The royal family then returned in their carriages to the palace, while the troops marched back to their barracks, where they were served with extra rations. 


\section{CHAPTER VII}

\section{$A$ King's Courtship}

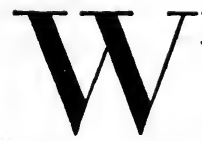

THEN I arrived in Madrid in May, 1905, as American Minister Plenipotentiary, speculation was rife as to King Alfonso's probable choice of a princess to share with him the throne of Spain. It was the talk of the court, the Government, the diplomatic circle, and the people; while the press sought the latest information and published every rumor. Lists of the eligible princesses ranging in age from fifteen years to twenty-five were printed in the papers. These lists, it must be admitted, were not very long. The trips which the King made during that year to England, Germany, Austria, and Bavaria were understood to be in part for the purpose of enabling him to make the ceremonious visits which as a newly crowned monarch it was his duty to make upon his seniors upon the thrones of Europe, but even more to give him an opportunity to meet the princesses of these countries. There was from the first a quite general conviction that the King had made up his mind to marry into the English royal family. The reports which came to Madrid as early as June created the belief that he was very much in love with Princess Ena 
of Battenberg, granddaughter of Queen Victoria, and that he had found favor in her eyes. Eight months, however, went by before any public announcement was made. Speculation and rumor increased. The King was much amused by it all, and he seemed delighted to keep up the mystery and the excitement. He had a small racing yacht of "knock-about" type, built at this time for his use at San Sebastian. When the day came to give it a name, someone suggested that it should be named after the future Queen. "All right," said the King. "Let it be named Queen X." He greeted his Ministers frequently by asking: "Well, to what princess have the papers married me this morning?" I recall an interesting incident in this connection. About three weeks before the engagement was announced, I went to the palace to present a distinguished American college professor. It was the first time the professor had stood in the presence of royalty. It was the first time that I had presented one of my compatriots to the King. We both expected an audience that would be formal and in accordance with the traditions as to the strict etiquette of the Spanish court. In a few words I made the presentation and then stepped back a foot or two to leave the King and the professor together. Imagine my astonishment as, in English as perfect as that which follows and, I think, in these very words and without any trace of accent, the King said: "You must excuse me, Professor, if I speak to you in bad English. You have probably read in the papers, Professor, all 
these articles about my intending to marry an English princess. Why, just imagine anyone who speaks English as poorly as I do marrying an English princess."

"Pardon me," said the Professor, delighted by the informality and cordiality of the reception, "Your Majesty speaks English quite perfectly."

Then the King said to him in Spanish, "But you speak Castilian," and in that language they conversed for several minutes. When we left the room both the professor and myself felt that a king who had mastered the English language so completely had won an English bride, and that announcement of the fact would not be deferred long.

The love-making of royalty is hedged about with many restrictions and is beset with difficulties. Not only is the list of eligibles small, but royal lovers cannot pay court with the same freedom as the humble born. Besides, the constitutions of their realms prescribe qualifications for their consorts, especially religious requirements, and the mutual relations of states and dynasties of ten override the feelings of the heart. Furthermore, everything that affects the Crown must be done with so much formality. There must be special ambassadors sent to the King or Emperor, head of the family to which the princess belongs, to ask his consent, and other plenipotentiaries must be appointed by the two sovereigns to sign the treaty containing the marriage contract, and the same or other plenipotentiaries to sign the renunciation of the princess and her 
husband-to-be of all her rights to succeed to the throne of the country which she is leaving. These, or nearly all these, formalities had to be carried out in the case of King Alfonso, but notwithstanding them, this young monarch, not then twenty years of age, found opportunities to see his princess, and he demonstrated clearly that he was an ardent and devoted lover.

When, toward the end of January, 1906, it was announced in the papers that Princess Ena and her mother, Princess Beatrice (Princess Henry of Battenberg), were to visit Princess Frederica of Hanover at her villa, Mouriscot, in Biarritz, near the Spanish frontier, and that King Alfonso was to go to San Sebastian, only about thirty miles away, and from there would make an excursion to Mouriscot to visit the Princesses, everyone realized that the royal love story was to be told. What followed showed that King Alfonso was rightly characterized by one of the newspapers of the day as the "whirlwind lover"; for after his first excursion he made many others, racing over, early each morning, in his big automobile, which he himself ran, from the villa of Miramar at San Sebastian to the villa of Mouriscot at Biarritz, thirty miles, in forty minutes and usually arriving there before the Princess had breakfasted, spending the day with her or automobiling with her and her mother, and then at night returning to San Sebastian, only to set out again the next day for another visit to Mouriscot. The courtship was idyllic, and the Spanish people, almost universally, were delighted in the happi- 
ness of their King and well satisfied that his choice was for the best interest of the nation and dynasty. At the end of a week he had to return to Madrid. Back in his capital, with plenty of king's business to do, with daily rumors of cabinet crises and Governmental changes, the King was a lover constant in his attentions. Many letters and telegrams were exchanged daily, and those for the King were delivered to him wherever he was and were read then and there. I remember seeing one delivered to him during the musicale in the palace given in honor of the Portuguese sovereigns, when he and they were all seated together. With Queen Amelia's permission the seal was broken and the letter read forthwith by the King, while the musicians went on with their playing. When Princess Ena was in San Sebastian she expressed to the King her fondness for Spanish oranges. When she was returning to England she stopped for several days in Paris. The Spanish Embassy in that capital received a despatch that the King was sending to it "some oranges" to be delivered to Princess Ena of Battenberg. The quantity was not stated. The Embassy did not know whether to arrange for the delivery of a box or a barrel. Imagine its surprise when there was delivered to it for presentation to the Princess a full-sized orange tree in its native earth, loaded with golden fruit.

It was arranged that the Princess with her mother should visit Queen Maria Christina at San Sebastian in the month of March. There the King and his mother arrived one morning. The 
King escorted his mother to the villa of Miramar and gave a few directions as to arrangements for the reception of the Princesses, whom he was to meet that afternoon at Irun, the little frontier station, twenty miles away. In a few minutes, however, he was off in his automobile for Hendaye, the first station in France. There he caught the Sud Express, the same train he had come on from Madrid, which made half an hour's stop at the frontier, and in it he went to Angoulème, almost halfway to Paris, to meet his fiancée and to surprise her. During this visit to San Sebastian Princess Ena was received into the Catholic Church. The engagement was then officially announced by Princess Beatrice to King Edward of England, and by King Alfonso to his Prime Minister in order that the latter might make the necessary statement to the Cortes as required by the constitution of the realm. By ail the political parties except the Carlists and the Integrists (ultra-clericals) the engagement was approved. An annual grant of four hundred and fifty thousand pesetas, equal to about ninety thousand dollars, was voted to the new Queen as long as the King lived, and two hundred and fifty thousand pesetas annually during widowhood. These were the same allowances as had been made to Maria Christina.

In May the King left Madrid to spend three weeks with his fiancée and Princess Beatrice on the Isle of Wight, crossing over from Cherbourg in his yacht, the Giralda. The accounts published of the goings, comings, and doings of the 
King and the Princess would indicate that those three weeks were ideal and idyllic, the life that was led being charming in its simplicity and its absolute freedom from the restrictions of court etiquette.

A princess who weds a king must go to his country that the ceremony of marriage may be performed there, although in ancient days the king of ten sent a personal representative to her country, and a marriage with him as the king's proxy was celebrated there, and another ceremony was celebrated after her arrival at the capital, when the king in person appeared and took the marriage vows. On the twenty-fourth of May, Princess Ena took leave of England for Spain, her wedding day having been fixed for the thirty-first of May. Accompanied by her mother, brothers, and suite, she left the station at London cheered and speeded by the good-byes and good wishes of King Edward and of all the British royal family and by the vivas of the Spanish Embassy and Spanish colony. At Dover the Counsellor of the Spanish Embassy to Great Britain, the Marquis of Villalobar, one of Spain's most able young diplomats, and more recently His Majesty's Minister at Washington and Lisbon, escorted her from the train to the boat, the Spanish Vice-Consul also being there to greet her. The Marquis of Villalobar travelled with the Princess and her party all the way to Madrid. At Calais she was met by the Spanish Ambassador to France and by the British Consul, and at Paris was greeted by the British Ambassador and by the staff of the Span- 
I24 THE COURT OF HIS CATHOLIC MAJESTY ish Embassy and by the Consulate of that country. At all these places the stations were trimmed with Spanish and English or French flags. People everywhere showed a lively interest, and many floral offerings were made to the Princess. All along the route it was a royal journey fit for one who was soon to become a queen.

On the same day that Princess Ena left Paris for Madrid, King Alfonso, accompanied by the Prime Minister, the Minister of War, the Lord Chamberlain, and some other high officials and two of his aids and the British Ambassador, left his capital for Irun, the frontier town in the north of Spain. The station in this little place was hung with garlands of flowers and foliage and was festooned with British and Spanish flags. A company of halberdiers which had come from Madrid took up a position as a guard of honor. Shortly after the King's arrival, the train bearing Princess Ena and her family entered the station amid the booming of cannon, while the band struck up the British national anthem, and thousands of spectators shouted their vivas. Addresses of welcome were read to her by provincial authorities, bouquets were presented to her, the troops were reviewed, and the royal train with the King and his fancée and their suites started for Madrid.

It was a journey of over four hundred miles. It was one continuous ovation. To describe its details as reported in the press would be wearisome. At every stop great cheering crowds had gathered; troops were drawn up to render honors; bands were playing national anthems; women 
were waving handkerchiefs; municipal and provincial authorities advanced to deliver addresses of welcome; bouquets by hundreds were presented, until the Princess's car was one great floral bower, and in many places a perfect rain of flowers was showered upon the train. In the towns with great garrisons all the regiments were drawn up along the railroad. The spectators at several places numbered twenty thousand. All the stations had been decorated with plants and flowers, and all were gay with bunting and with inscriptions of welcome and with flags, British as well as Spanish. This triumphal progress continued without cessation until at last the train arrived at El Plantio, a temporary station about five miles from Madrid and only a few miles from the Royal Palace of the Pardo, where Princess Ena and her family were to lodge until the wedding day. At El Plantio the royal family and a brilliant assemblage of the Ministers of the Crown, court functionaries, and nobles were awaiting Don Alfonso and his bride. Hundreds of spectators, many of them peasants, were there with flowers to throw at the Princess, and here, too, there were addresses of welcome from the simple communal authorities of the little village, addresses very brief, but manifestly sincere.

From El Plantio to El Pardo the future Queen with her mother and with Queen Maria Christina drove in a carriage drawn by four mules, with King Alfonso, mounted upon his horse, riding at their side. Mules, be it known, have always been greatly preferred by the royalty of 
Spain and by its aristocratic classes for driving in the country. At one time no one but royalty was allowed to use them on pleasure carriages. In the cities to-day they do the heavy teaming; and out of one hundred fine carriages seen, not over five are drawn by mules; but go for a drive from the city into the country, and teams of from two to four galloping mules are constantly met with, no small portion of them owned by city residents. Almost daily when in Madrid I used to see some members of the royal family driving in the Casa de Campo or toward El Pardo in carriages drawn by four mules; but in later years, except for the children, the automobile is displacing the mule. I ought to add, however, that I never saw any of these teams of mules balky or stuck. I cannot say as much of automobiles; and when both mules and automobiles were working their best it was a question which were the speedier, for a team of four Spanish mules at full gallop can cover the ground rapidly.

Enthusiastic greetings were given Princess Ena on her drive to the Pardo and upon her arrival there. Here in this country palace, six miles from Madrid, situated in a royal demesne that is well wooded for Spain, Maria Christina had lodged before her marriage to Alfonso XII, and here Princess Ena and her family were to spend the five days intervening between her arrival and her wedding day. Daily King Alfonso rushed out from Madrid to take her and her mother in his automobile for an excursion to the Escorial, for a ride through the grounds of the Casa de Campo, 


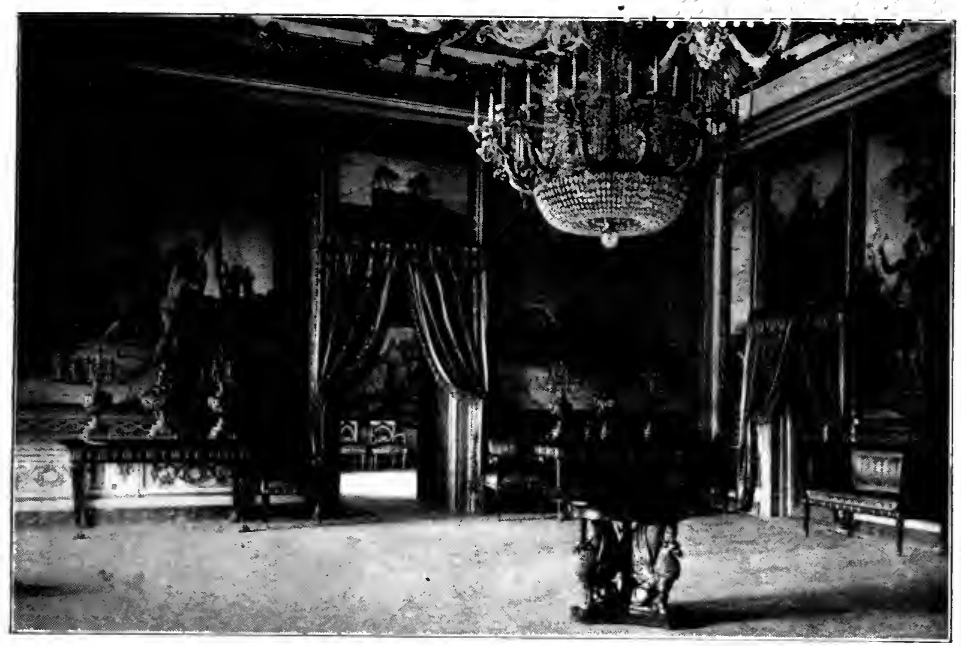

\section{Photo by Franzen}

Pardo Palace. Salon of Ambassadors, Tapestries After Goya

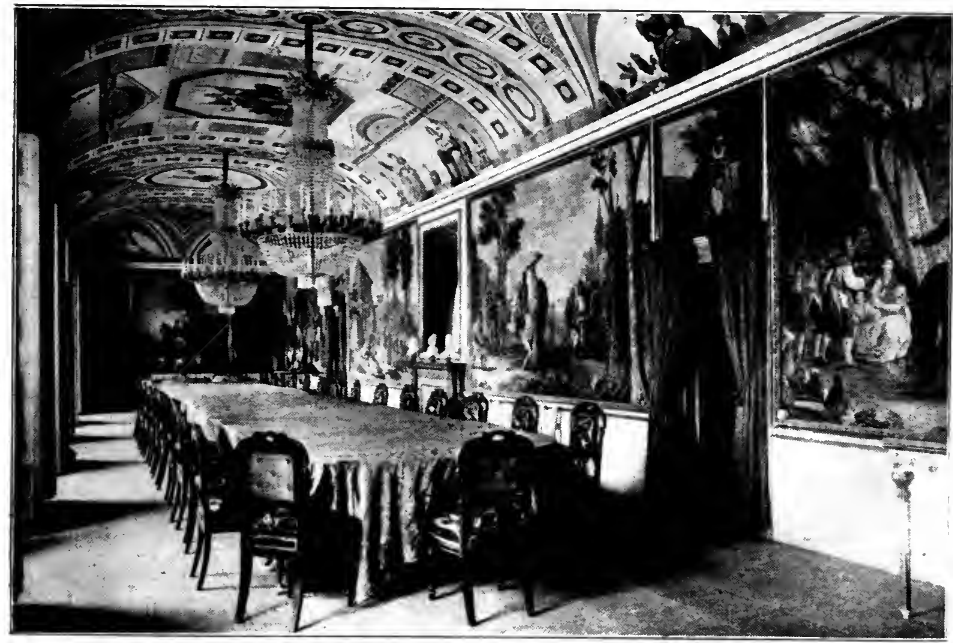

Photo by Franzen

Pardo Palace. The Dining-Room 


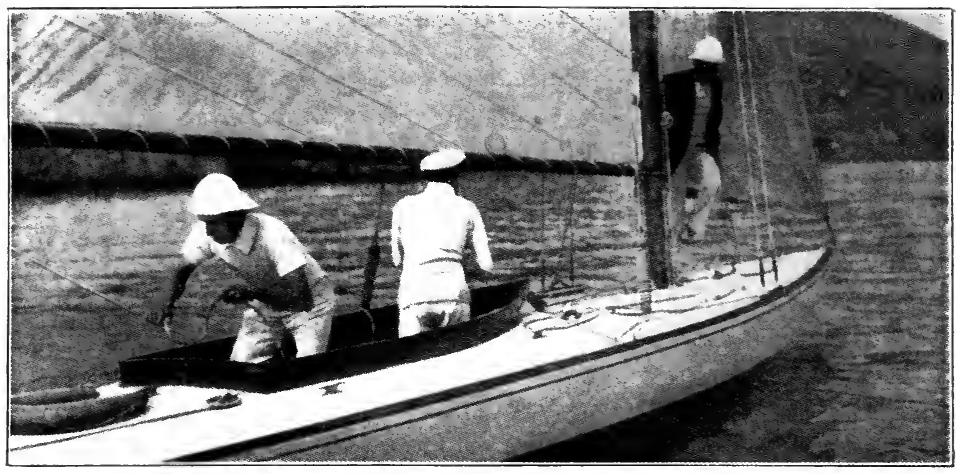

Royal Yachting. The King at the Ropes

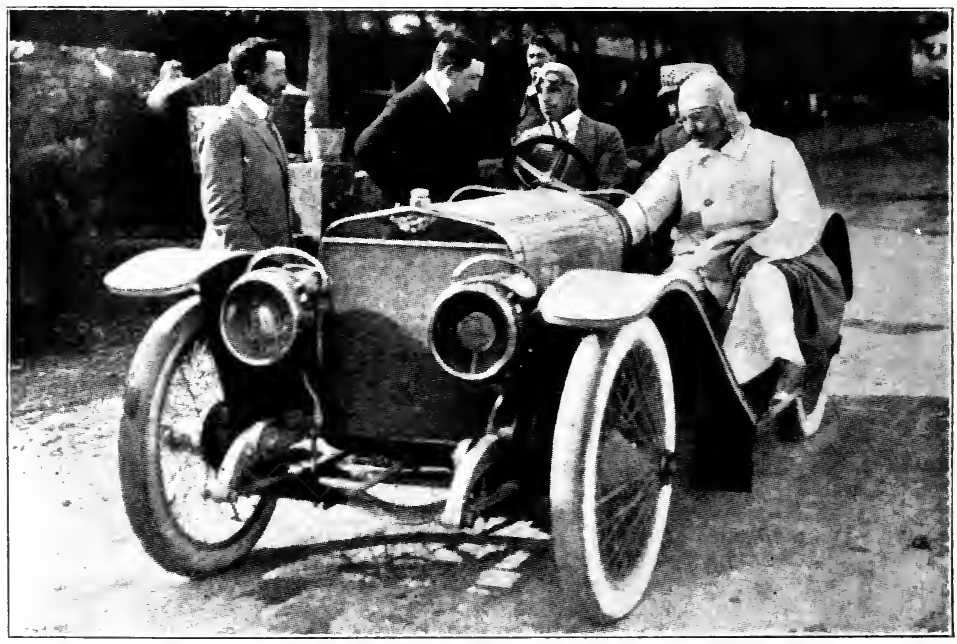

From "Nuevo M undo"

The King as an Automobilist Making a Trip from San Sebastian to Madrid 
a royal demesne continuing that of the Pardo right up to the palace gates at Madrid, or sometimes taking her and her suite by Moncloa, or by the direct road along the Manzanares to the Royal Palace in Madrid to inspect its apartments, to lunch, or to receive some of the foreign princes who were arriving for the wedding.

An automobile procession from Madrid to the Pardo, to be reviewed by the Princess, was gotten up in her honor. There was a well organized automobile club in Madrid, its membership including only the wealthiest and most aristocratic class. With poor roads in Spain and bad pavements in Madrid and gasolene selling at a price equivalent to ninety-five cents a gallon, automobiling was in that day, in Spain the sport only of the very rich. The King was an enthusiastic automobilist and a skilful and daring driver himself. I recall an account published in one of the staid and serious papers of San Sebastian in the Summer of 1905, as to an automobile excursion that he made from San Sebastian to Soria to witness the unveiling of the monument erected on the site of the ancient city of Numantia, which in olden times resisted the Romans so stubbornly that the heroism of its inhabitants is one of the glories of Spanish history. The distance was about one hundred and twenty miles through a very mountainous country. There had been some fatal automobile accidents in the vicinity. The Ministers of the Crown were continually counselling the King to greater prudence, and Maria Christina, his mother, had obtained from him, it 
was said, a promise that he would not undertake long journeys en auto without having two other automobiles accompany him, in one of which should go certain members of his suite and also one of the court physicians, and that upon his arrival at his destination he would immediately telephone her to relieve her of further anxiety. Describing the Soria trip, the San Sebastian paper said:

"His Majesty left Miramar by the main [front] entrance at ten minutes past nine and had proceeded less than a quarter of a mile when a tire burst. $\mathrm{He}$ determined to change it himself, and so, in his automobile, went by another road to the garage in the rear of the palace. While he was working, someone said to him, 'Your Majesty, the suite that should follow you has gone on ahead by the main road.' 'Oh, that makes no difference. I will soon pass them.' At ten o'clock, the tire being changed, Don Alfonso started again, travelling rapidly, and arrived at Soria without incident at half-past one o'clock, and at once telephoned his august mother that the nearer of the two automobiles which were accompanying him was twenty miles in the rear."

But no accident ever came to the King. He was quick to think and quick to act, and he handled his car well, and doubtless the fears as to his carefulness were never fully justified. In later years, although he automobiled a great deal, it did not seem to me that he cared as much for it as a sport, preferring yachting when in the vicinity of San Sebastian and the other Biscayan towns, and polo when in Madrid.

It was really a beautiful sight on Monday morning, three days before the wedding, when the King in his automobile, as honorary president of the 
Automobile Club, with Princess Beatrice of Great Britain at his side, the Infante Don Carlos in his automobile, the Infanta Isabella in hers, and the young Princes of Battenberg in another, joined the procession in front of the Royal Palace. Some of the automobiles were covered with flowers, and all bore the flags of Great Britain and Spain. The company embraced the most distinguished of the nobles of the kingdom and the most beautiful of the women of the Court of Madrid. Barcelona automobilists had also come from that city to participate in the fête, and there were about one hundred and twenty-five cars in line. At the Pardo, Princess Ena and Queen Maria Christina stood on one of the balconies as the automobiles, in column formation, moved by and performed certain evolutions, while their occupants cheered the Queen-to-be and the Queen-thatwas and the ladies waved their handkerchiefs.

Now the wedding guests began to arrive. Nearly forty royal princes and princesses came; among them four heirs to thrones, of whom two are now kings. All those who came from the north were brought from the frontier in a special royal train and were met at the station by all the members of the royal family except the King, and by the Government, the great military chiefs, the high court officials, and the embassies of their respective countries. Military guards of honor lined the railway platform when they arrived, and as each prince alighted the band played the national hymn of his country. It was a veritable "Concert of Europe." Dragoons were 
I3O THE COURT OF HIS CATHOLIC MAJESTY drawn up outside of the station, and with a suitable military escort each prince was conducted to the Royal Palace or to the private palace which had been assigned to him. Those princes who were related to the family of the bride were, as a rule, lodged in the Royal Palace.

The special embassies sent by the republics of the world and by a few of the smaller monarchies were also arriving in these days, and they were hospitably and splendidly housed and entertained at the expense of the Spanish Government, which insisted upon its right to play the role of host during their entire stay in Madrid, and which would not permit the suggestion of a return of hospitalities by their guests or of reciprocal entertainment by them. How thoroughly the Government looked to the comfort of its guests was illustrated by its attentions to Mr. Whitridge, the Special Ambassador from the United States. It hired for his occupancy an old but handsome and commodious palace belonging to the Duchess of Pinohermoso, one of the ladies of the Queen and a prominent member of the court circle. It was situated in the Calle Amor de Dios (Street of the Love of God). It was specially furnished by the Spanish Government from top to bottom, completely, comfortably, handsomely, artistically, and to my own knowledge, a person representing the firm that had furnished it was required by the Government to remain in the house all the time, so that if he overheard the slightest expression of a wish or of a want by any member of Mr. Whitridge's staff or family, whether it was a change 
of the menu or an objection to the service, the need of a piece of furniture or of a paper of pins, he could instantly see that it was supplied. Food and service were all provided by the Spanish Government. The chefs were the best that could be obtained; enormous wages were paid to them, and more than one permanent resident at Madrid, in those days, had occasion to regret the sudden departure of servants lured away by offers which gave them a chance to earn three months' wages in three weeks. Horses and carriages, liveried coachmen and footmen, with galons and distinctive cockades, were also provided. What was done for Mr. Whitridge was done for all Special Ambassadors. They were guests of the Spanish nation, and no more allowed to pay for anything than would the guest of a private person. One Special Ambassador expressed to the Spanish Government the desire of giving a dinner in honor of certain high Spanish officials. He was politely told that of course he could do so, if there was any hour during his stay when he would have no engagement (so complete was the programme for his entertainment which the Government had provided), but that the bill for the dinner which he would give would be paid by the Spanish Government, as he was its guest.

Two nights before the wedding, I attended, at the Pardo Palace, a most interesting festivity which had been planned by Maria Christina. It was a performance in the little theatre of this palace, consisting of one of Miguel Echegaray's comedies, "Echar la Llave," followed by a sainete 
(literally a tidbit), a form of short Spanish comedy or satire, specially composed for the occasion and intended to illustrate popular life in Madrid a little more than one hundred years ago. It was so arranged that, as the play was performed, the actors, in carrying out their parts, became grouped so that they formed living reproductions of some of Goya's best known pictures of picnics on the banks of the Manzanares, of street scenes in Madrid, of the bull-fighters and the beaux, the peasants and the priests, the cavaliers and the shopkeepers, of that epoch. It was a most artistic performance by the best of Spanish actors and actresses. But it was even more remarkable for the eminent distinction of those who constituted the audience. It was a most select company, notwithstanding that the theatre was filled. The entire audience consisted of only one hundred and eight persons. One of these was the King; one was the Queen Mother; another was the Queento-be; thirty-four others were royal princes and princesses, and the remainder were the Ambassadors and Ministers Plenipotentiary permanently accredited to Madrid, the wives of the Ambassadors, a few high court officials, the ladies of the Queen, and one (but only one) from each prince's suite. The Special Ambassadors had not up to that time presented their credentials and were not invited. It was in the strictest sense a gala performance. Women wore their handsomest dresses and jewels and the men their showiest uniforms, with orders and decorations; all the men except two I should have said - one of 


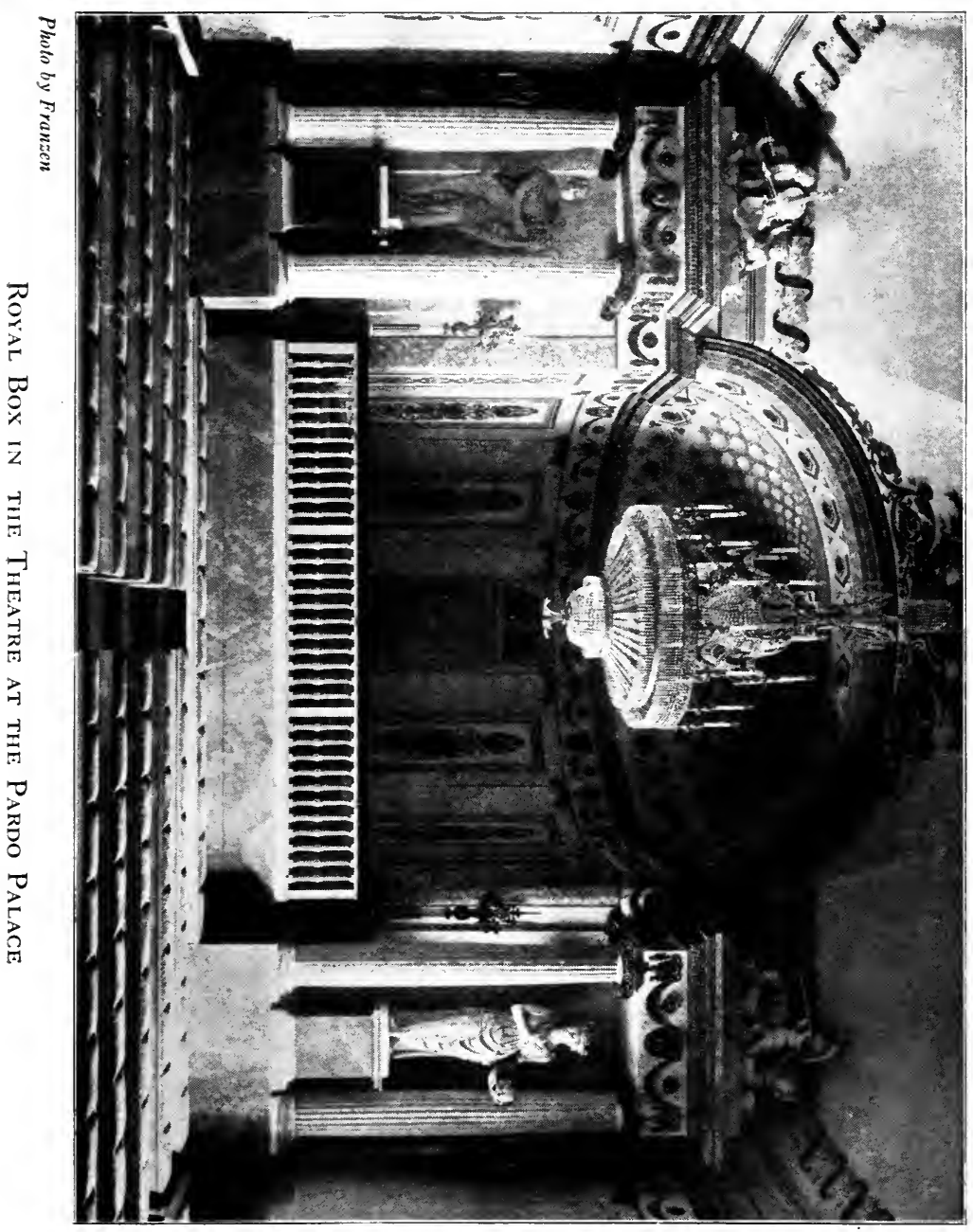


$\therefore \vdots \vdots \because \because \because \because \because \because \vdots \quad \vdots \therefore \square^{\prime} \because \vdots$

ง 
them an Englishman, who had come in the suite of one of the princesses and who wore an English velvet court dress, and myself, who, in obedience to American laws, which forbade uniforms, wore an evening dress coat. I had lived so long in Madrid that by this time I did not feel ill at ease in this dress when all the others were wearing uniforms, but it was with some amusement that the next day I read in one of the papers an account of this function which, in describing its very recherché character, said: "The attendance was strictly limited, there being present one hundred and six uniforms and two dress coats."

In the audience were the Prince and Princess of Wales (now King George V and Queen Mary of England); Prince Albert (now King Albert, of Belgium; Archduke Franz Ferdinand, heir presumptive of Austria-Hungary; Prince Louis Philippe, the heir apparent of Portugal, but who was two years later assassinated at the same time as his father, King Carlos; Prince Thomas of Italy, Duke of Genoa, and the Duchess of Genoa; Prince Andrew of Greece, son of King George; Prince Eugene of Sweden, son of King Oscar; Grandduke Vladimir, uncle of the Czar and son of Alexander II, the Czar who was assassinated in I88I ; the Crown Prince of Monaco; Prince Albert of Prussia, Regent of Brunswick, and his son Prince Frederick Henry of Prussia; Princes Ludwig Ferdinand and Alfonso of Bavaria; the Grand Duchess Maria of Saxe-Coburg-Gotha and her daughter Princess Beatrice; Princess Frederica of Hanover; Prince and Princess Alexander of 
I34 THE COURT OF HIS CATHOLIC MAJESTY

Teck; Princess Pilar of Bavaria; the three brothers of the Infante Don Carlos; the three brothers of the Princess Ena, and the Prince and Princess of Erbach Schoenberg, besides all the Infantes and Infantas of Spain. After the performance of the sainete had been concluded all the audience went downstairs into the dining-room, where a buffet supper was served. Here the royal and other guests mingled freely together, many presentations being made in a quite formal manner. At one o'clock the King left for Madrid in his automobile, and soon the diplomats and other guests started back on their six-mile ride to the city.

As a sign how organizations of every kind endeavored to do something to add to the festivities of the King's approaching wedding, mention might be made that the Aero Club arranged a grand balloon ascension, twelve monster balloons being sent up in the vicinity of the Royal Palace.

Many hours of those five days which intervened between Princess Ena's arrival and her wedding day were given up by the King to receiving the visiting princes, to returning the calls they made upon him, and to granting audiences to the Special Embassies; while Princess Ena received delegations from the Province of Madrid, from Catalonia, from the Press Association, from the Senate, and from the House of Deputies, all presenting addresses of welcome, of felicitation, of loyalty. Most interesting to us, and doubtless most pleasing to the future Queen, was that which was pronounced by Señor Canalejas, then 
President of the House of Deputies, now known throughout the world as the President of the Council of Ministers (Prime Minister). Heading a committee of twelve deputies, every one of whom had, at some time, been a Minister of the Crown, he said to Princess Ena:

"Señora, the President of the Chamber of Deputies believes that he is the interpreter of the sentiments of the nation when he assures Your Royal Highness that if the people had had to choose a consort for their King, as the King has chosen a Queen for his people, they would have made the same choice. The aspirations of the love of the King have coincided with the sincere wishes of the people, as is revealed by their enthusiasm. It is certain that the future Queen of Spain will be so loved here that she will never have reason to sigh for the country of her birth.

"The King has given public proof that he has learned how to be a model son and an exemplary brother, and it is equally certain that in this union, inspired by love and so pleasing to the country, there is every reason to believe that an august Princess has acquired a model and exemplary husband.

"In working for the happiness of the King Your Royal Highness will contribute to the welfare of Spain, for whose greatness it is well worthy that we all should labor."

All those who are acquainted with the great Prime Minister, and with the positiveness of his convictions and the frankness of his statements, know that he did not speak as a flatterer, but that 
I36 THE COURT OF HIS CATHOLIC MAJESTY he voiced his sincere belief. And all those in . Madrid, in court or Government or diplomatic circles, who had known Don Alfonso as a boy, as a young man, and as a lover, realized that Señor Canalejas's tribute to him as a son and brother was never better deserved by anyone, and they felt sure that with the past as an augury of the future, the King's courtship would be followed by a royal marriage that would bring nothing but happiness to him and to the bride who had been won by his love. 


\section{CHAPTER VIII}

\section{The Royal Wedding}

$7 \mathrm{HE}$ sun smiled on the King's wedding day, Thursday, May 3I, I906. The sky was 1 cloudless and of an azure blue such as is found nowhere so clear and so perfect as on the high plateau of New Castile far from the sea and its moisture-laden breezes. But it was hot, stiflingly hot, like a burning August day in the United States. King Alfonso had risen early and before half-past six o'clock had reached the Pardo Palace. He attended mass with Princess Ena and breakfasted and by eight o'clock had brought her and Princess Beatrice to the Ministry of Marine in Madrid, near the Royal Palace, which had been furnished and set apart for her, and in which she was to be robed in her wedding dress, and from which she with her retinue was to start for the church.

Not only had the King observed the Spanish custom according to which the groom gives to the bride her wedding dress, but he had insisted that it should be made in Spain and that it should be a veritable chef d'cuvre of the national creative skill and a marvel of needlework. There are ladies in plenty who assert that "one can get nothing in Madrid," and it must be admitted 
I38 THE COURT OF HIS CATHOLIC MAJESTY

that practically all go to Paris for their fine gowns. But the bridal dress of Princess Ena shows what can be done even in Madrid, if a dressmaker is only given an order and has a mind to try and, perhaps, is paid enough. It is true forty women, all Spaniards, worked continuously for fifty-six days on this dress, and its lace was said to have cost one hundred and fifty dollars a yard, and the gown with its court train was declared by all the newspapers to be worth twenty thousand dollars. To describe it I must quote another, for that is a task beyond my powers, and all that I remember of what I saw a few hours later is the bride passing up the broad aisle of the church to the altar, a tall, fair-haired young girl with rosy cheeks, - a vision of loveliness and a perfect beauty. Jewels and orange blossoms were in her hair. A long bridal veil floated over her face and she wore a dress of rich satin with shimmering silver and finest lace and a long court train with the lilies of the Bourbons thickly strewn over it. But for details let us go to Calvert, that voluminous but always entertaining writer on Spain. In his book, "The Spanish Royal Marriage," printed for private distribution only, and by permission dedicated to the King and Queen, he says of it:

"The style of the dress was pure Louis Seize and the principal material was the richest satin and cloth of silver. The dress was bordered with dull silver, slightly burnished here and there, and trimmed with magnificent rose point which was festooned over a foundation of cloth of silver, the lace flounce being half a metre wide. The whole was relieved with loops of orange blossom. The superb mantle or train 


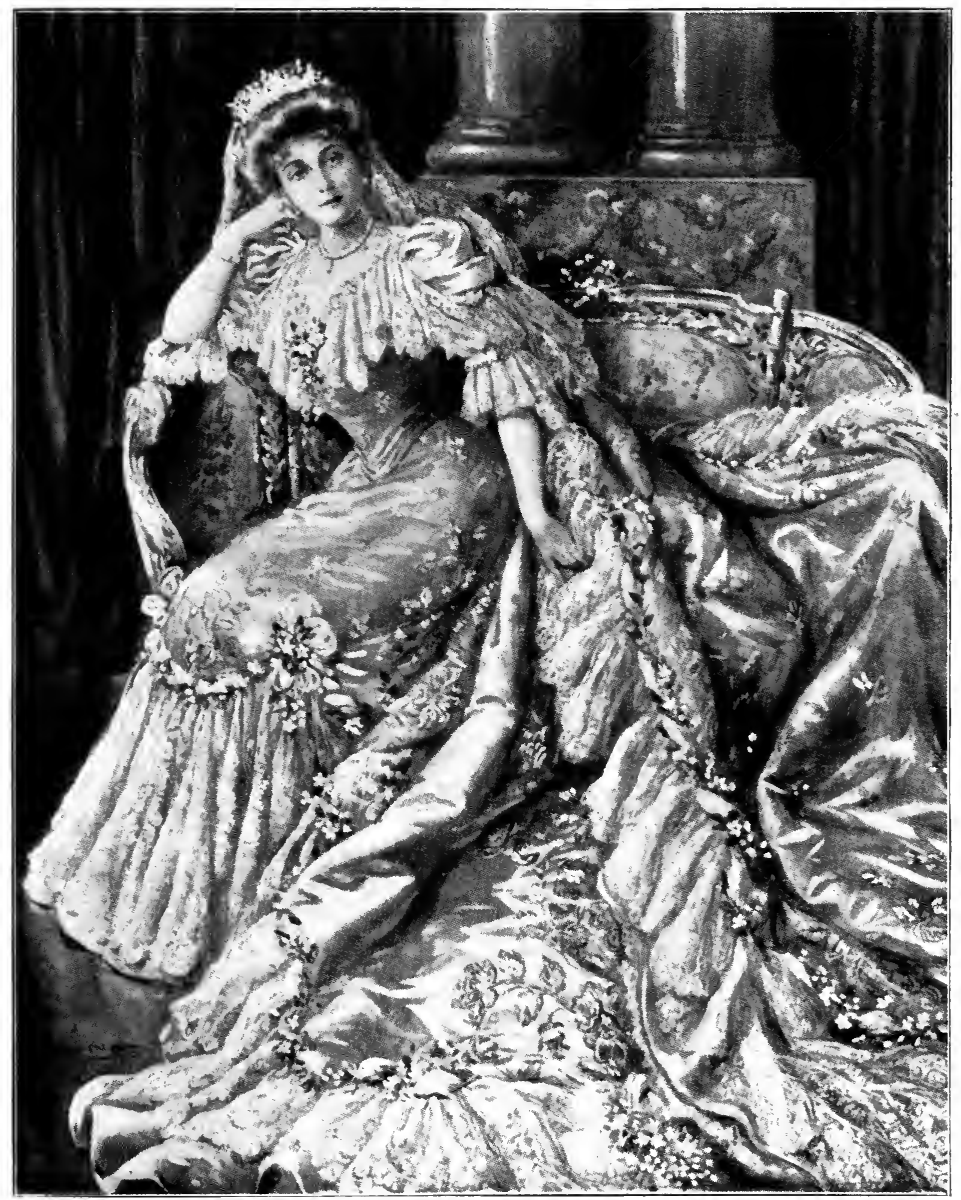

Photo by A.F. Calvert

The QueEn in Her Wedding-dress 
$\because \because: \quad, \because \because \because \vdots i=$

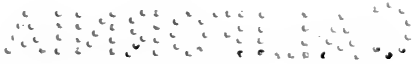


hung from the shoulders in Watteau pleats, and was four and a half metres long. It was of cloth of silver sown with small fleurs-de-lis, the special Bourbon emblem, and was bordered with exquisite lace of the same pattern as that worn on the dress, delicately festooned and having a narrow edge of orange blossoms."

Weeks of work had made Madrid a veritable fairy city. In the streets through or near which the wedding cortège was to pass, hundreds of flower-covered arches had been erected, flags and coats of arms by thousands had been flung, and festoons innumerable stretched across the streets. Venetian masts had been placed all along the way. Their long floating banners were composed, some of the colors of Spain, some of those of Great Britain. Pictures of the King and of the Queen-to-be, framed in flowers, had been suspended all along the route, and banners with inscriptions of welcome and good wishes greeted the eye everywhere. All the buildings, public and private, were profusely, tastefully, and beautifully decorated: Every Madrid house, it should be known, has a balcony at every window, and almost every householder has, as a necessary furnishing for every balcony, colgaduras, or hangings of velvet or silk. These are of a variety of colors and are decorated and embroidered with the coat of arms, the monogram, or the initials of the owner. Thus the capital city can always be quickly decked in holiday attire; thus there is always infinite variety yet perfect harmony in this festal garb of Madrid. But on the King's wedding day, besides these 
I40 THE COURT OF HIS CATHOLIC MAJESTY

customary colgaduras there were flags flying from almost every house and trophies of arms grouped upon their façades along with festoons of flowers, sometimes real and sometimes artificial. The city was beautiful in the daytime; at night it was entrancing. Electric lights were strung everywhere. The great private houses and all public buildings were outlined with them and magnificent decorations in many colors were ablaze with light. Almost every garland and festoon in the streets was threaded with a string of tiny electric bulbs, and arches and columns and masts were all illuminated in this way.

And the city was also gay with the color of dress and costume. Mingled with the light summer gowns of the ladies of the capital, with their ever-moving brightly painted fans and their parasols of various colors, were to be seen the distinctive costumes of the peasants from nearly all the provinces, who had come in tens of thousands to see the pageantry of the wedding and to participate in the popular festivities of the week to follow. Certainly two hundred and fifty thousand people - perhaps three hundred and fifty thousand - crowded the houses and public buildings, jammed the sidewalks and packed the grandstands that had been placed along the streets through which the wedding procession was to pass. The route to the church was about a mile and a half long, and the return about two miles. Both going and returning the cortège was to pass through the Puerta del Sol, the busy central square of the city, the focus of its activity, and 
the very heart of its arterial system; for into it and out of it, through ten great streets which here converge, flow constant hurried streams of people passing from one part of the city to others.

For centuries all royal weddings in Madrid had been celebrated in the Church of the Atocha before the altar of that Virgin who is specially revered by the Spanish royal family because of her frequent miraculous intervention in its behalf. But Atocha's ancient church is demolished and the one to replace it is not finished. San Geronimo el Real, just back of the Prado Museum, was chosen for that reason, and also because its location and its distance from the palace made possible an extended route through the principal streets for the royal cortège, which, in magnificence and splendor, was to revive the memories of Spain's greatest days and was to surpass all other pageants ever seen. San Geronimo is a little church - a single broad nave without aisles or transept. Only a few hundred people can be seated in it even when every inch of space is utilized. It had, of course, been regally decorated for the occasion. Magnificent tapestries adorned its walls. A carpet of lovely coloring upon a white ground had been specially woven at the Royal Carpet and Tapestry Factory and covered the broad passageway up which the bridal party was to come. A splendid throne with wide-extended velvet canopy had been erected in the chancel on the evangel side. Handsomely furnished tribunes had been built along the sides of the nave, and in front of them had 
I42 THE COURT OF HIS CATHOLIC MAJESTY been placed great gilded armchairs for the visiting princes and princesses. Velvet-covered benches and settees had been placed for the grandees of Spain. White flowers, roses, carnations, and orange blossoms surrounded the altar, and many thousands of electric lamps twinkled in the dimly lighted church.

Those who were to witness the ceremony except the royal princes and princesses and those grandees who were to form a part of the cortège - had been invited and, indeed, instructed to reach the church long before the time set for the arrival of the King; and a special route to the church had been designated for them, part of it leading along the walks of the "park. All these arrangements were necessitated by the inconceivably enormous crowds and by the stopping, long before the cortège arrived, of all transit through or across the troop-guarded streets along which it was to pass. Therefore I went early to the church accompanied by Mrs. Collier. A little after half-past eight we were seated in the tribune assigned to the permanent Diplomatic Corps on the right side, just next to the chairs where the foreign princes were to sit. In our box, as in that of the Government, farther up toward the chancel, there was show of uniform and the beauty and grace of woman; for the wives of the Ministers of the Crown and those of the permanent Diplomatic Corps had been invited to attend the ceremony. Mrs. Collier had the distinction of being the only American lady invited to attend the wedding ceremony. 
Opposite us, near the King's throne, was the tribune of the Special Ambassadors and Special Ministers and their suites, who were sent as a special honor to Spain on this happy occasion. It was a more than usually interesting group of men. - As always in a Diplomatic Corps, there were in it men from the uttermost parts of the earth, but on this day there were to be seen Ambassadors from countries which rarely send a diplomatic representative. The most striking figure of all was the Caid from Morocco, who, wrapped from head to foot in his long white robes, sat imperturbable and unmoved by anything that he saw, although he seemed to be the most close observer of everything. Near him, conspicuous in his tribune, as I in mine, by his evening dress suit, was President Roosevelt's Special Ambassador, Mr. Frederick W. Whitridge, a most distinguished and cultured citizen of New York. America could not have had a better representative, and his addresses to the King when he presented his letters credential and when he took leave were gems of oratory, felicitously conceived, charmingly composed, and elegantly delivered.

No ladies accompanied the Special Ambassadors to the church, for, when some months earlier the Spanish Government had expressed to other Governments the pleasure with which it would receive special embassies and special legations, it had been obliged to manifest its wish that no ladies should accompany them, because of its inability to tender them that hospitality which it 
I44 THE COURT OF HIS CATHOLIC MAJESTY desired to show and which, in fact, it extended with almost Oriental lavishness to the Special Ambassadors and Special Ministers and their suites. Still, in some instances, ladies had started for Madrid before the situation was understood, and although they had no official standing at Madrid and attended none of the festivities with their husbands in an official character, nevertheless the traditional gallantry of the Spaniards saw that many courtesies were shown them.

When those who were familiar with Spanish politics saw the wives of the Ministers of the Crown, in their handsome dresses, enter their tribune, they could not help recalling how for months there had been rumors that the Government was to resign. No one outside of Spain can realize what a dreadful thing it is for a Prime Minister to have one of his Ministers decide to give up his portfolio. It is the sign of the break-up of the Government, and the Spaniards invariably call this break-up a "crisis." For twenty weeks, at least, prior to the King's marriage, a crisis had been impending, and all Madrid had been told that nothing would prevent it unless it were the declared intention of the wives of the Ministers of the Crown that, having ordered their dresses for the royal wedding, they would attend it, that their husbands should not resign, and that the crisis should be postponed until after that event. In less than a week after the wedding the crisis did actually occur and the Government fell. The wedding guests continued to arrive at the church. A half-dozen Knights of the Golden 
Fleece who were not of royal blood, ladies of the Queen, ambassadors of Spain in foreign countries with their wives, delegations from the Senate and the House of Deputies and other governmental bodies, the most eminent of the generals of the army and the admirals of the navy, the great chiefs of the hierarchy, chosen representatives of the military orders, and a few private guests of the King and of the Queen-to-be soon filled every seat in the little church except those reserved for the King and his bride and the royal personages and grandees who were forming a part of the wedding procession.

At half-past nine o'clock cannons boomed, and bells rang, and the royal cortege set out from the palace. To describe its splendor and magnificence would task the powers of the most graphic writer. To try to tell of the animation and enthusiasm and excitement of the hundreds of thousands who cheered its passage would be to attempt the impossible. Seated in the church, awaiting the coming of the royal party, I saw it only when it approached the church door; but the ovations given the King as he passed along the route, even when far away could be heard, and told us of the progress made. On the way to the church there were in reality two separate processions, that of the King, grand and imposing; that of the Princess, much smaller, but exciting no less interest. At the head of the King's cortège were mounted outriders. Then came eight equerries in rich dark blue and gold uniforms, followed by mounted drummers with silver side-drums. 
I46 THE COURT OF HIS CATHOLIC MAJESTY

Four trumpeters came after them, and four macebearers on horseback, in rich red and gold uniforms. Then, led by grooms, there followed four horses in Oriental trappings and eight more gayly caparisoned and bearing antique saddles, and then sixteen more wearing different trappings and accoutrements corresponding to the sixteen different regiments (four of them foreign) of which the King is colonel. Then came twentyfive grandees of Spain, each in his ancient family state carriage, painted in the colors adopted by his house and emblazoned with its arms. A hundred years ago - yes, in some cases, much more than that - the ancestors of these same grandees had driven in these same coaches in similar grand pageants. The carriages were as beautiful in their interior decorations as they were handsomely painted without. Many of them were upholstered in finest silks and brocades. The panels of not a few of them had been painted long years ago by the great artists of those epochs. Each of these carriages was drawn by only two horses (none but those of royalty were allowed more), but the harnesses glistened in the sun like gold, and upon the horses' heads were great waving plumes. Coachmen and footmen with powdered hair and wearing bright-colored liveries, consisting of long coats, knee breeches, silk stockings, low shoes with great silver buckles, and three-cornered hats, gave a mediæval aspect to the scene. The footmen walked beside the carriages and carried enormous canes or batons.

Now came more than twenty carriages from 
the royal stables. In the "bronze landau" were the four kings-at-arms in their showy scarlet dalmatics; then, in media-gala carriages, certain palace functionaries, and in grand state carriages the princes and princesses; first those of Spain, then those of other countries, but who are related to the Spanish royal family, and finally those who were there as the personal representatives of their sovereigns and who, as the guests of highest rank, rode in the carriages immediately preceding that of the King. Six horses with mounted postilions drew each of these carriages of the visiting princes, and a detachment of sixteen men from the Escolta Real rode with each. Except these small escorts and the guard that followed the King's carriage, no other soldiers were in the procession, although thousands of them lined the way. This cortège, it should be remembered, was not a military parade, but a court procession. Some of the coaches were almost dazzling in splendor. One of them was entirely veneered with tortoise shell; another, called the "coach of the gold panels," had panels that were veritably of gold, and was a gift to Charles IV from the Viceroy of Mexico when that country was still a Spanish colony. Another was the "royal crown coach." On its top were two golden globes which supported the royal crown, to symbolize Spain's sovereignty in the Old and in the New World. This coach was constructed for Maria Christina of Bourbon, fourth wife of Ferdinand VII, and it was emblazoned with the arms of Spain and also with those of Naples, her native country. It was uphol- 
stered in purple velvet and embroidered in silk. On the way to the church the King rode in this coach, accompanied by his brother-in-law, the Infante Don Carlos, who was to be his padrino (godfather), or "best man" as we would say, and the latter's little son, the Infantito Alfonso, who was then the heir presumptive to the throne. Cheers greeted them everywhere as they passed, and the King's delight was apparent. Just ahead of them, the "coach of the gold panels" was going absolutely empty as the "coach of respect," in accordance with Spanish custom. The underlying idea of this is not to have an emergency carriage at hand, but to add éclat and brilliancy to the pageant. But how useful that carriage was on the return from the church on this day I will soon tell. Eight white horses, splendidly caparisoned, drew the carriage of the King. It moved in a hollow square of halberdiers, while at the right of it and very close rode the Captain General of Madrid, Señor Villar y Villate, tall, commanding, erect, the most magnificent looking son of Mars whom I ever knew. On the left was General Bascaran, Chief of the Military Household. Close to the carriage were the equerries of the King. Three companies of cavalry, with colors and trumpeters, followed. Then came the Minister of Gobernacion (Minister of Internal Government), charged with the general supervision of police measures, and behind him a section of artillery brought up the rear.

Upon reaching the church the Infantes and Infantas, the princes and princesses, entered and 
in couples were escorted to their places. The court trains of all the ladies were carried by train-bearers. As they went up the aisle they bowed and courtesied as they passed the different tribunes. Then the Royal March was played and under a baldaquin held by six priests the King passed up to the throne. He was in full uniform - long coat, white satin breeches, high patent leather boots with gold spurs - and he wore the decorations of all the principal Spanish orders. He was preceded, as he came up the aisle, by the Lord Chamberlain and the Master of the Horse, and with him under the baldaquin was his padrino, Don Carlos, and between them the little Prince Alfonso, who won the sympathetic interest of everyone.

A half-hour after the King's cortège left the Royal Palace, that of the Princess set out from the Ministry of Marine. There were but five carriages in this, including that of Señor Moret, the Prime Minister. In the first three were the ladies and gentlemen in waiting on the Princess and on Queen Maria Christina and on the Battenberg princes. Princess Ena with her mother and with Maria Christina, her future mother-in-law and madrina, rode in the "mahogany state coach," drawn by six horses, with a postilion riding on the first. Mounted guards and lancers preceded them and the Escolta Real followed. There was, of course, immense curiosity to see the bride, and as she passed her beauty captivated everyone. Women waved their handkerchiefs wildly, and men cheered no less excitedly. 
I5O THE COURT OF HIS CATHOLIC MAJESTY

At the church there was a long wait for the bride. It had been calculated that her procession would reach the edifice as soon as the King alighted from his carriage, but certainly at least half an hour elapsed after he took his place in the chancel before the Princess arrived. Meanwhile people grew apprehensive; there was a feeling that some accident had occurred. Even at that time some wondered if an anarchistic attempt had been made; for Barcelona had long been a hot-bed of anarchy and threats against the King had been frequently made, and it was recalled that the attempt upon his life which so nearly resulted fatally had taken place in Paris just exactly a year previous to that very day. The King plainly showed signs of nervousness as the minutes ran on, and he called one of the chamberlains to the throne to make inquiries. Relief came at last. The three young Battenberg princes who were in the cortège accompanying their sister entered, the eldest in naval uniform, the two youngest in Scotch Highlander suits, the royal Stuart plaid. One of the latter wore long trousers, the other wore kilts. As they passed up the aisles, escorted by the Introducer of Ambassadors, bowing now to the Congress on the right, now to the Senate on the left, now to the permanent Diplomatic Corps, and next to the Special Ambassadors, and then in turn to the various royal personages, no princes, young or old, showed more self-possession, more alertness, more manliness or more courtliness, than these young boys.

Again the Royal March was heard, and beneath 


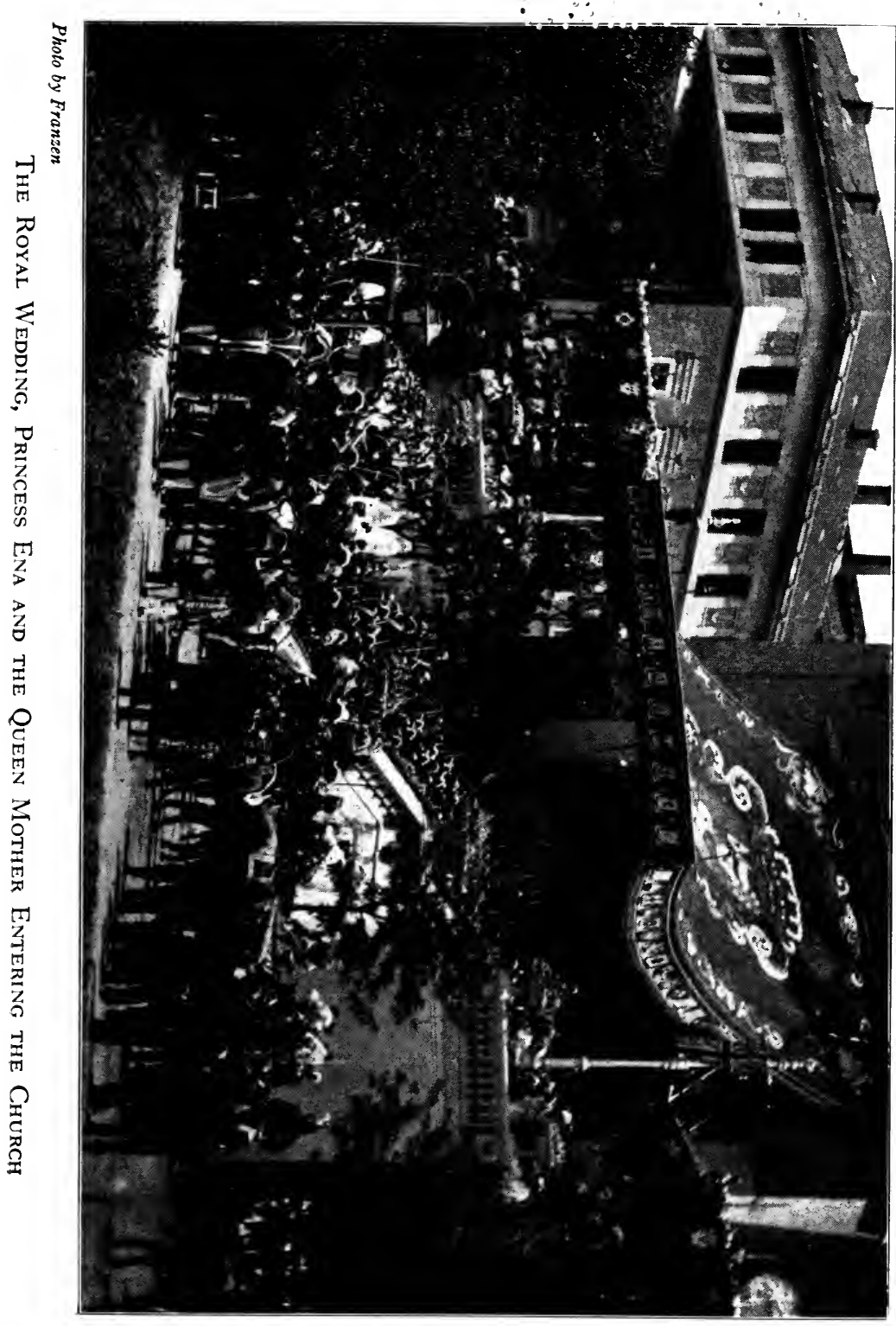




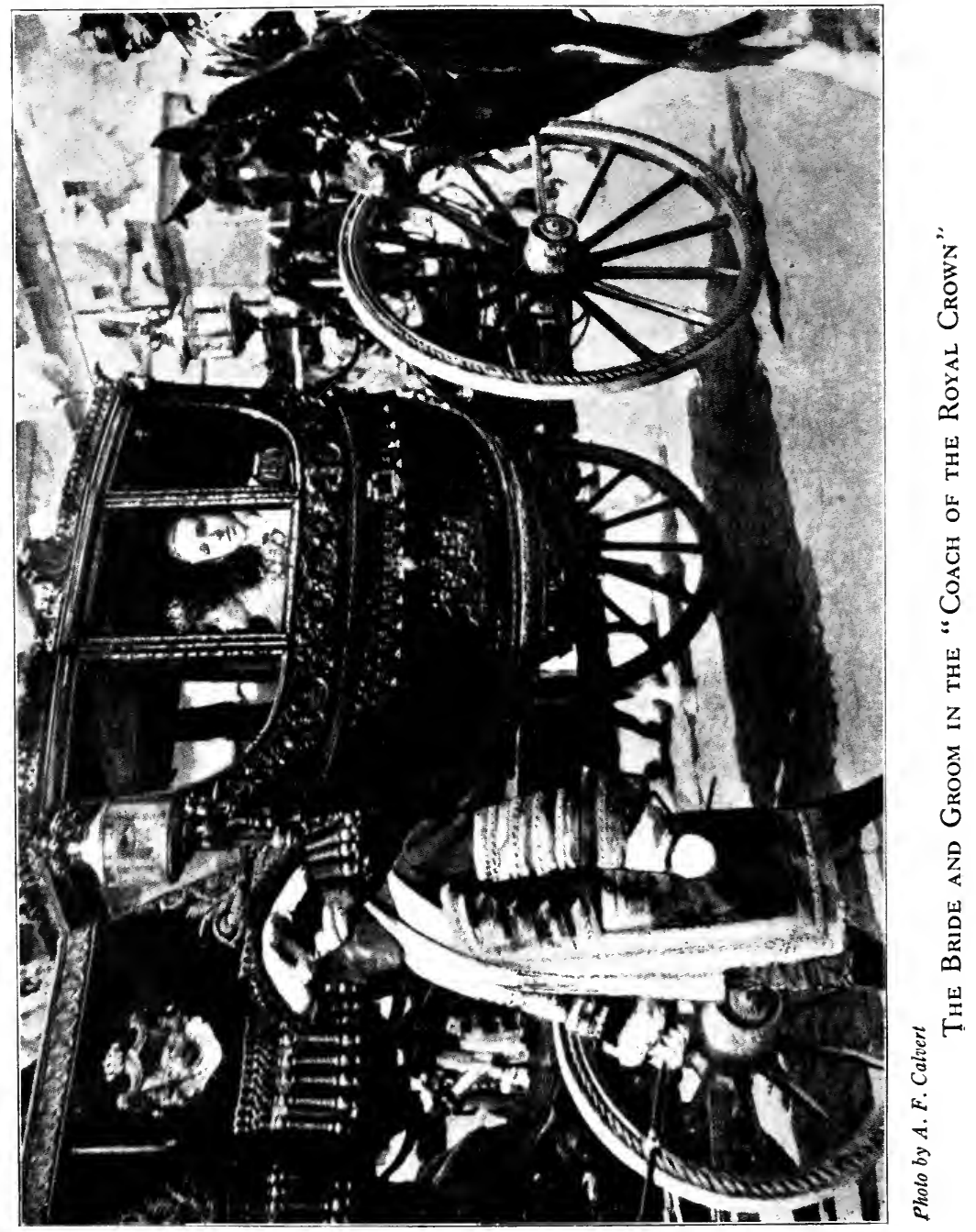


the baldaquin the bride, Princess Ena, with the Queen Mother, Maria Christina, on her left, holding her hand, and with her own, mother, Princess Beatrice, on the right and just a step behind, advanced slowly up the aisle. To say that the bride was radiantly, superbly beautiful is not flattery. One could not say less and speak the truth. The King descended from his throne and with Princess Ena went up in front of the altar, where they knelt, Maria Christina as madrina being at the left of the bride, and Don Carlos as padrino at the right of the groom. Princess Beatrice sat some distance away near the other princesses of the family.

The Cardinal Archbishop of Toledo officiated. The English Bishop of Nottingham, who had confirmed Princess Ena when she entered the Catholic Church, was present in the chancel. It was the same service as that always required by the Roman ritual, the same as I had attended when the Infanta Maria Theresa was married, and about which I have written. There was the same solemn demand made three times that if either knew of any impediment to the marriage they should make it known. There were the same questions put to the contracting parties. When the King was asked if he wished the Princess as his lawful spouse and wife, he went, just as his sister had done at her wedding, to his mother, knelt and kissed her and received her permission; and Princess Ena, when the same question was put to her, went down from the altar to where her mother sat in the body of the church and kissed 
I52 THE COURT OF HIS CATHOLIC MAJESTY

her and obtained her permission. There was the same blessing and giving of the rings and of the arras, the same putting of the veil and of the conjugal yoke over the heads and shoulders of the bride and groom, and the same final "Ite in pace," (Go in peace). But this time the arras consisted of thirteen ounces of gold instead of thirteen coins.

When the mass was finished the King and Queen went, arm in arm, out of a side door into the old cloisters of the church, where a place had been prepared for signing the register of the marriage. All the princes and princesses followed them and signed it. Returning, the King and Queen took their places upon the throne, and then in the order of their precedence, but beginning with the lowest in rank, the order in which they would ride back to the palace, the princes and princesses, in couples, rose from their seats, advanced in front of the throne, bowed and courtesied to the young sovereigns, and left the church. To all a bow of recognition was given. Last of all, Maria Christina rose, advanced, and made a low courtesy to the King and to the Queen who had come to the throne upon which she once had sat; but in her case the King and Queen rose simultaneously and bowed and courtesied with equal deference. One of Don Alfonso's earliest acts after assuming the government, when sixteen years of age, had been to decree that his mother should always have precedence over every woman in Spain, except the woman whom he might thereafter choose as his wife. The King 
and Queen together left the church, and then the diplomats, who had been there over four hours, drove home to their respective residences.

The royal cortège started on its return to the palace, the King and Queen now riding together in the coach of the royal crown. The long journey back was one continuous triumph. Vivas were shouted constantly; handkerchiefs were waved, and white doves with ribbons of red and yellow, the national colors, tied around their necks were let loose and flew above the royal carriage. The enthusiasm of the people increased as the cortige progressed, and the young couple, plainly delighted by their reception and blissfully happy, were bowing and saluting constantly. The Queen was waving her handkerchief to the people, who were cheering her wildly. In the Puerta del Sol the enthusiasm was almost delirious. So great was the crowd, and so many times was the slow-moving procession stopped,. that it took more than a quarter of an hour to pass through this small square. All the time, without an instant's cessation, the tens of thousands who were massed there were cheering and waving handkerchiefs. Into the narrow but ever busy and crowded Calle Mayor (Main Street) the cortege now entered. Here are situated the Ayuntamiento (City Hall), the Provincial Government Buildings, and at the end, near where one turns to go to the Royal Palace, the Italian Embassy and the Palace of the Council of State. Just before the latter is a little church situated slightly back from the street, leaving a small 
I54 THE COURT OF HIS CATHOLIC MAJESTY square where an enormous grandstand had been erected, which was crowded with several thousand spectators. Enthusiasm increased as the cortège advanced toward the palace. The foreign princes were acclaimed. Maria Christina, Princess Beatrice, Don Carlos and his little son, the Infantito Alfonso, who were now all in the same carriage, were receiving a continuous ovation, and the popular excitement as the young King and Queen approached was frenzied.

Their carriage had now come just in front of the little church, near the Council of State and almost opposite the Italian Embassy. In a minute they would turn the corner; in three or four minutes they would be in the palace. Suddenly from out of an upper story window of the house next before the Italian Embassy something was tossed. It looked like a bouquet of flowers, such as had been thrown to the King and Queen by many persons along the route, although police regulations had forbidden such acts. There was a flash, a deafening noise, a rattling of broken glass, shrieks and cries. A blinding smoke concealed the royal carriage. When it cleared away one saw soldiers stretched out on the ground, horses kicking in agony, men dead, men dying. Panic seized the crowd, which fled precipitately, men, women and children falling over each other. The Captain General, aides-de-camp, and equerries who were riding at the side or just behind the carriage rushed to the door of it. The King, whose first thought had been of his bride, and who had assured himself that she was uninjured, 
answered their inquiries with calmness, saying, "We are not injured. We will go on." But it was impossible to go on. The horse nearest the carriage lay dead, another was dying, and a third was badly wounded. The forward part of the carriage had been blown in, the lamps and windows had been shattered. The King thereupon helped the Queen out of the carriage. If there had been any manifestation of fright by her, there were no traces of it then. Indeed there is every reason to believe that both she and the King, although horrified by the deed, and shocked by the havoc that had been wrought, and stunned by the narrowness of their escape, and grieving for the suffering that had been occasioned to others, bore themselves throughout the whole tragedy with calmness and courage. As the bride got out of the carriage her wedding dress was stained with the blood of victims, for the sides of the carriage had been splashed with it. The royal couple were then escorted to the "coach of respect," which was just ahead of them, and, entering it, they proceeded to the palace. People cheered more fervidly than ever, and the young bride from time to time recognized their good wishes by waving her handkerchief. The King was calm but plainly depressed by this blot upon the joyous beauty of his wedding procession.

Although the anarchists' bomb had not injured the sovereigns, it had spread death and destruction all about them. Captain General Villar y Villate, who was riding at the right side of the carriage of the King, was hurled from his horse and slightly 
I56 THE COURT OF HIS CATHOLIC MAJESTY

wounded; Señor Alvarez de Toledo, the senior equerry of the King, who was riding near the royal carriage, was also slightly wounded, and a young officer of the Escolta Real, who was riding just behind, was fatally injured. Policemen, soldiers, and members of the Guardia Civil standing on the side of the carriage farthest from the building from which the bomb was thrown were killed, and several persons, spectators of the pageant, who were standing on the balconies of this building, met instant death. Several bystanders on the street were killed. The regiment of Wad-Ras (so called because of a Spanish victory in Morocco at the river of this name) was lining the way. It stood with arms presented as the carriage of the King approached. A captain, two lieutenants, and eight or ten of its men were killed, and thirty or forty were wounded. The wonderful discipline of the regiment was shown by the fact that its lines did not break. It continued to stand with arms presented, not a gun of the living lowered, not a man deserting his post. The total death roll was twenty-six, and one hundred and ten persons were officially reported as wounded, this number not including some whose injuries were so slight that they did not seek medical attendance in the hospitals or in the emergency relief stations. As soon as I was informed that a bomb had been hurled, I drove from my Legation to the palace to make inquiries and to express the sentiments of the American Government. I passed down the Calle Mayor almost to the scene of the outrage and met soldiers carrying away the dead and dying. 
Thus a wedding marked by the most splendid pageantry was darkened by a most awful tragedy. But in the desolation of the havoc wrought, in the sorrow and mortification that one of their own subjects had done so dastardly a deed, there remained and forever will remain to the young King and Queen, as their most precious possession, as the brightest augury of their happiness, and as the strongest inspiration to them to work for Spain and its advancement, the memory of the sincere and fervent good wishes, the greetings and the cheers of the hundreds of thousands who that day, seeing their young King, admired him, and beholding their new Queen, loved her, and who, witnessing the happiness of the royal couple, vowed to them loyal support. 


\section{CHAPTER IX}

\section{Wedding Festivities}

N elaborate programme of festivities, filling almost every hour of the eight days 1 following the royal wedding, had been
arranged. Should it be cancelled in view of the sorrow and suffering that had been caused by the anarchistic attempt? That was the question which confronted the authorities on Thursday afternoon. A hundred thousand people from the provinces had come to witness the celebration and to participate in the rejoicing. Should they be deprived of all the pleasure which they had anticipated? The assassin had not yet been captured, for the moment after he threw the bomb he rushed downstairs and in the confusion that existed he escaped in the crowd. Police investigations resulted in the arrest of many suspects. Madrid seemed a veritable nest of anarchists, and the populace was in a state of fear bordering on panic. Would the giving up of the festivities tend to allay or to excite this condition? This was the problem to be solved. The decision reached was to carry out the programme as outlined, except that the palace ball should become a reception without music and dancing. 
On the evening of the day of the wedding, as well as throughout all the following week, the city was illuminated. Nothing can surpass the fairylike beauty which it assumed when lighted by the myriads of electric lights that had been strung in every section, but especially along the streets through which the wedding cortège had passed and in those running into the Puerta del Sol. Here tens of thousands of people gathered the first night, enchanted by the brilliancy of the scene. There was a sudden noise of explosion. People fled in wildest panic, bursting into shops, offices, newspaper booths, and even into private houses, seeking to escape from what they supposed was another bomb. In the rush many were knocked down and severely injured. It was an automobile tire which had burst - "that, and nothing more." As soon as the crowd knew the cause of their fright they were reassured and resumed their wanderings through the street and around the square, admiring the decorations and enjoying the fascinating sights.

In all quarters of the city on that night and every succeeding night for a whole week there were popular festivities for the masses, - balls, concerts, verbenas, - the least formal, but perhaps the most enjoyable of all the merry-making of which the King's wedding was the occasion.

In the Royal Palace that night there was no grand festivity. Fortunately none had been planned, and there would have been little heart for mirth and gayety, although there was, of course, wedding joy and the happiness of young lovers 
I60 THE COURT OF HIS CATHOLIC MAJESTY

forever united. There was the royal family wedding dinner, - a dinner intime, - and the bride cut the great wedding cake, the first wedding cake ever seen in Spain; for Don Alfonso had decided that his English bride should bring with her this English custom. How much interest the Spaniards had taken in it! Had not the papers given its measurements in metres, its height and diameter? and to give us a better idea, had they not told us in detail how each "story" of this six-story wedding cake was decorated? Had we not seen pictures of it in all the papers? This cake, it should be known, was made in England, but had arrived in Madrid about two weeks before the wedding. It was six feet high and its base was over twelve feet in circumference; and although it was not "heavy," it weighed over three hundred pounds. Well that there was so much of it, for after the bride once cut it, it was cut into an infinite number of small pieces, put into little satin-covered boxes bearing the picture of the King and Queen, and given to each of the several hundred guests who attended the great state dinners given by Their Majesties during the week that followed; namely, the dinner for the royal family and related princes; the dinner for the royal princes who had come in representation of the sovereigns of their countries and for the Special Ambassadors and Special Ministers, and finally, the dinner for us, men and women of the permanent Diplomatic Corps, and the princes of the royal family.

On Thursday afternoon, and on several days 
thereafter, all the world, with his brother and his sister also, wended his way to the palace to write his name (and, if a Spaniard, to make under his name his rubric, his own distinctive scroll or loop or flourish, usually a work of art in chirography, without which no Spaniard considers his signature complete) in the books set apart for the purpose; for this is the means of expressing one's felicitations in the days of joy or one's sympathy in the hour of sorrow when one cannot personally call or be received. Everybody in Madrid, from the Cardinal Primate down to the humblest citizen, wished on these days not only to congratulate the young sovereigns upon their wedding, but much more to testify to the universal joy that they had escaped injury.

In the square in front of the palace there was always plenty of the idle curious, sitting on the steps of the park or standing around, hoping that they would see something of interest, - the King and Queen at the window, perhaps; some great foreign prince, perchance, going out for a ride; the arrival of the Prime Minister possibly, or, may be, the change of the military guard. Friday morning, toward noon, the crowd, numbering several hundred, did see a sight. It saw what I consider not only an act of bravery, but of wise policy, - the young King and Queen, who the day before had so miraculously escaped death, coming out of the palace, in his automobile, absolutely alone, without a guard, a detective, an attendant, or even a chauffeur, for the King was himself running the automobile. They came to 
make an excursion through the streets in order to prove their confidence in the loyalty of their subjects and to show them that they were well. The surprise of the people was very great. It soon turned into enthusiastic admiration, which found expression in cheers and in demonstrations of affection. As they proceeded slowly along the Calle Arenal, the crowds increased in numbers and the ovation became more and more impressive. In the Puerta del Sol there were about three thousand people. As soon as the King and Queen were recognized, excitement knew no bounds. People rushed from the sidewalk, surrounded the automobile, almost stopping its progress, and cheered and gave every form of expression to their delight. Women from the balconies waved their handkerchiefs, and the King stood up in his automobile to bow to them. Boys and men caught hold of the automobile and, hanging on to it, ran along with it on its course through the streets. The King and Queen traversed nearly the whole route taken by the wedding cortège the day before. Returning, they passed a second time through the Puerta del Sol, and the crowd was now so great that they had to stop several times to avoid running over people. Back to the palace they went, through crowds almost delirious with excitement. Arriving there, they rose in the automobile and stood for several minutes, the King saluting and the Queen bowing and waving her hand. Meantime the police were busy seeking the anarchist and arresting suspects.

Late Friday afternoon sombre and sorrowful 
funeral processions slowly passed through the streets. The victims of the crime of the day before were being carried to their graves, for municipal regulations in Madrid require interment within twenty-four hours after death. At all these funerals the royal family was represented. Most impressive of these sad cortèges, so different from that of the day before, was the long file of eight hearses bearing the bodies of the heroic dead of the Wad-Ras Regiment. With horses draped with heavy palls of black, with crowns of immortelles piled over the caskets, with the mourners all following on foot, as is the custom in Spain, it was truly a pitiful sight. Next to the hearses the Infante Don Carlos walked as the representative of the King, accompanied by the Infante Don Fernando, Prince Alexander of Battenberg, and the Princes of Orleans and of Bourbon-Naples. There also were Señor Moret, the Prime Minister, the head of the Government, and Señor Maura, the leader of the Conservatives, the opposition party, with a large number of the chief personages of that party; Captain General Villar y Villate, and Lopez Dominguez and Canalejas and others high in place and power who were there to testify to their admiration for the dead, their sorrow at their death, their hatred of anarchy, and their devotion to the State. The King, who had gone that afternoon to the chapel where the bodies of the dead lay, and who had visited each of the wounded in the hospitals, had expressed his intention of following the dead to the grave, on foot, as chief mourner; but the Prime Minister had 
counselled him not to do so, fearing for his safety. While the procession was moving through the street an aide-de-camp rode up to say that His Majesty still desired to show the dead this honor. The Prime Minister held a Council of Ministers on the spot and sent back word that it was their advice that the King should not thus expose himself. Coming back from the cemetery the Infantes and Prince Alexander of Battenberg were without escort, except as crowds of cheering men and boys flocked around them and accompanied them to the palace. I was driving in the Calle Arenal and happened to meet them. As the tall young princes strode fearlessly along in the centre of the crowd of men and boys who were pressing close up to them and continually shouting vivas, the unity of the people and the crown was proved by the royal family's confidence in the loyalty of the masses and by its bravery, from the King and Queen down to the youngest Infante, in spite of the assassin's dastardly attack.

On Friday night a dinner was given in the palace to the foreign princes, the Special Ambassadors, and Special Ministers. After it the members of their suites were presented to the King and Queen.

Saturday afternoon was the date of the corrida real (the royal bull-fight), a festivity with which royal weddings in Spain have been celebrated from time immemorial. The American is almost sure to go to see a bull-fight when he visits Spain, almost sure to condemn it, and almost sure to admit that as a spectacle it is magnificent, at least so far as the assemblage of people is concerned. 
It was my first and last corrida real, and my description cannot do it justice. Next to the wedding cortège it was certainly the event to the majority of Spaniards, for the great amphitheatre was packed, no less than thirteen thousand people finding places in it. Every seat had been allotted to an invited guest and transfers had been strictly prohibited; yet it was notorious that the tickets of some who did not attend fell into the hands of speculators, who sold them, and that the price was forty dollars for a seat in the shade. Thirteen thousand people hurrying out to the Plaza de toros (bull ring), at the edge of the city, meant animation, excitement, bustle, and movement in Madrid. Every conveyance in the town was pressed into service. There one could see state carriages from the royal stables carrying princes and princesses, with mounted escorts accompanying them. There, too, were the landaus of Ambassadors and Ministers with their gallooned coachmen and footmen, the equipages of the nobility, the automobiles of the rich, the coaches from the livery stables, the cabs of the street, omnibuses, chars-à-bancs, carts, and cars of every style, of every epoch, and of every condition. Besides, there were thousands who, unable to obtain a carriage of any kind, walked; and scores of thousands stood on the side walks watching the crowd go by and waiting to see the King and Queen.

Inside the ring all was animation and stir. There was the tireless movement of at least eight thousand fans, all painted in bright colors, for 
I66 THE COURT OF HIS CATHOLIC MAJESTY

the majority of the spectators were women, and there was the continuous hum of conversation of thirteen thousand people all on the qui vive. It was an assemblage of enormous numbers, yet of unsurpassed brilliance. In the centre of one of the tiers of boxes was the great royal box decorated with flags, and coats of arms. At the right and left were the boxes for the Diplomatic Corps and the special embassies, and near them boxes for all the official world. In other boxes and in seats were thousands of Madrid's citizens in private life. In all sections of the great amphitheatre one could see uniforms and decorations, and mingled with them the white mantillas of the women. One section, or tendido, had, however, been set aside exclusively for five hundred of the most prominent women of the aristocracy of the capital. In it was not one man, not a dark coat, nor even a dark dress, to mar the fair picture of loveliness in white. All the ladies in this section wore light-colored summer dresses with red and yellow carnations pinned to the corsage or placed in the hair. Many of them also wore mantones de Manila, those white silk shawls embroidered with birds and flowers and foliage in bright colors. This group of five hundred women constituted a scene which those who were present cannot forget. As long as beauty shall have its admirers, it will not fade from the memory. To most Americans it is a pleasure to recall such scenes, and to them an earth that holds so much beauty is a very good place in which to live. But would you know the Spanish temperament? 
Would you know how this show of beauty moved the Spanish caballeros de Madrid? Listen, then, to this extract from the account of the corrida real published in the staid La Epoca:

"Attention was concentrated chiefly on Section IX set apart for the ladies of Madrid society. Hundreds of señoras and señoritas, most beautiful, occupied it, all dressed in bright gowns of light colors, all displaying on their heads the classic mantilla of white lace. It was a group indescribable. There were beauty, wealth, joy; and on these fair women were turned, without ceasing, the opera glasses of the lovers of beauty. It was veritably the section of beauty. How much prettiness of face! how much elegance of figure! As some one has said: 'From there to Heaven! A little while in Section IX, and then to die!'”

In the clear blue sky above the roofless arena floated many kites bearing inscriptions such as "Long live the King and Queen!" "Long live the bride and groom!" Over the balconies and doors of the building were rich red hangings bordered in gold. The columns that upheld the various tiers of galleries were wound with garlands of evergreen and with flowers, and the arena, the sand or earth where within a few minutes the actual fighting was to take place, was covered with a carpet of flowers made then and there, in the presence of the spectators, by florists who had been brought from the far-away Canary Islands, one of Spain's remaining colonial possessions, where the spreading of flowers in such a way as to form carpets is a highly developed special art. Days before they are wanted the flowers are torn apart. A vast quantity is, of course, needed. Leaves and petals of the same shade are thrown 
together in baskets. A great variety of colors is recognized. When the carpet is to be made, one man starts with his basket and strews the border; others scatter in the groundwork color; then others, one following another, pass along quickly in curving, flowing lines, sometimes spiral, sometimes circular, strewing flowers, weaving, as it were, the fanciful pattern of the carpet. Everyone was keenly interested in this exhibition of skill. All were delighted by this beautiful creation. It had taken weeks, even in the sunny Canaries, for these flowers to grow; it had taken days to pick them to pieces and to assort the colors; it had taken only minutes to strew them into this fairylike carpet. Puff, came the gentle breeze! It did not take a second to destroy our wonderful carpet. I think that I never saw anything which appeared to me more wasteful of Nature's favors. It seemed to me infinitely worse than the great extravagance of Philip V at La Granja; for if in the creation of the fountain which he said had cost him three millions and had amused him three minutes, he himself received but little for his money, thousands since then have found enjoyment in this great rival of Versailles. But our floral carpet was a mere heap of leaves in a minute, and in less than ten minutes was being trampled in the dust and dirt and offal of the bull-ring.

The multitudes that lined the streets leading from the palace to the Plaza de Toros, hoping to see the King and Queen pass, were doomed to disappointment; for, in order to avoid a possible anarchistic attempt, the authorities made the 
royal family go by a circuitous route. When they entered, a great ovation was tendered them. The whole thirteen thousand people rose and cheered. The Queen, according to custom, acted as president, tossing down the key which opens the pen where the bulls are confined and giving the directions as to when the successive stages of the fight should occur. There was great interest among the Spaniards in her attendance at this essentially Spanish sport. English repugnance toward it is well known. Indeed, the Prince and Princess of Wales did not attend, although all the other princes and the Special Ambassadors did, as also did Princess Beatrice, mother of the Queen.

Soon after the arrival of the royal party a door opened in the sheds underneath the gallery opposite the royal box and there issued a showy procession. First came four mounted alguaciles (constables or wardens) in costumes of the seventeenth century, and behind them came three grandees of Spain, in uniform, riding in their ancestral state carriages. They were the young Duke of Medinaceli, holder of the oldest title in the country, possessor of many ducal titles and many times a grandee; the Duke of Alba, possessor of almost as many titles and as many grandeeships as Medinaceli; and the Marquis (now Duke) of Tovar, a grandee of Spain, and at that time Spanish Ambassador to the Vatican. Magnificent were these ancestral carriages. They were, in fact, the same that these grandees had used in the wedding cortège two days previously. These three young grandees were in the bull-ring that day to act as the padrinos 
or patrons of three men who were to fight three bulls de caballeros - that is, as knights or gentlemen rather than as professional bull-fighters - and who were to fight con rejones; that is, with long spears and from horseback, killing the bulls if they could, but in no case allowing them to touch the horses. On this grand gala day nine bulls were to be fought, three in the ancient way described and six in the ordinary modern manner, in which the horses are horribly gored and killed. These three caballeros were all dressed in costumes of the time of Philip IV (seventeenth century) and they fought the bulls as did the cavaliers of the period of that monarch, whom Velasquez has immortalized in his portraits and who himself was always an active participant in equestrian sports. Preceded by the alguaciles, the carriages of the three grandees, in stately fashion, drove around the ring. As each came in front of the royal box, the footmen jumped down, opened the door of the carriage, and helped their lord to alight; and he, in turn, aiding his caballero bullfighter to get out, took him by the hand, led him close to the royal box, and bowing low presented him to Their Majesties. Then returning to his carriage, he helped his distinguished guest into it, got in himself, and when the footmen had taken their places on the rear of the carriage, the circuit of the bull-ring was completed. Behind the carriages came the cuadrillas, the band of professional bull-fighters and their corps of assistants. All were in the gorgeous suits which they are accustomed to wear, - suits of the brightest 


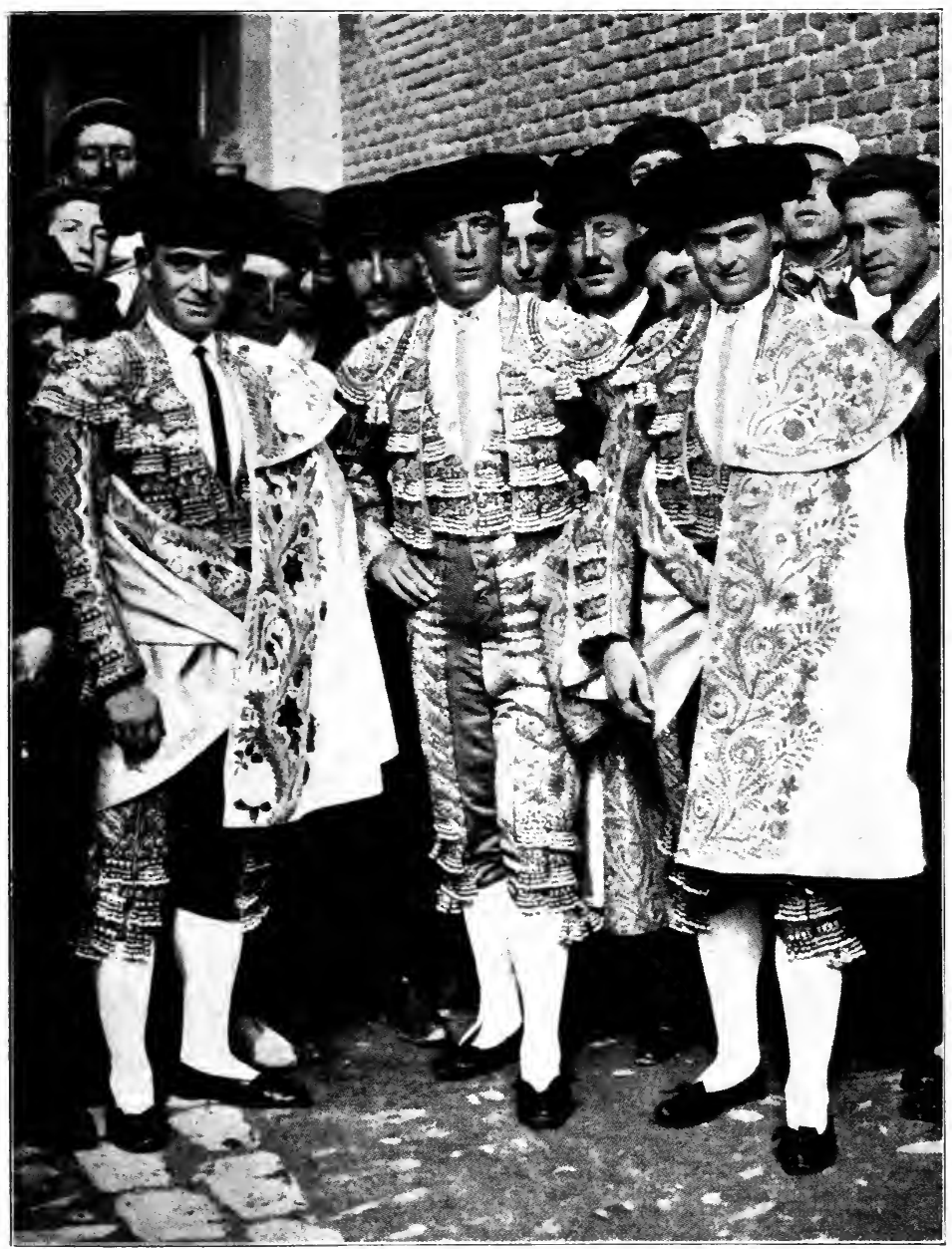

Photo from "Nuevo Mundo"

Three of Spain's most Celebrated Bull-fighters, "MachaQuito," "Cocherito" of Bilbao, and "Bombita" 
astonston 
colors and richest materials, completely covered with gold embroidery and not infrequently costing many hundreds of dollars. This day the greatest of the great in the profession of tauromachy were to fight: Fuentes, soon to retire with a fortune of a million or more francs that he had made in the arena; Bombita, whose prestige was then at its height; Machaquito and several others whose names were household words to nearly every Spanish person. Each of these great matadores (the men who usually appear only in the last stage or the last two stages of the fight and who with their swords actually give the final deadly thrust which kills the bull) has several assistants in his cuadrilla, These are of several classes: first, the picadores, who on horseback in the first stage of the ordinary bull-fight prick and goad the bull with long spears and who urge their horses up in front of him so that they may be gored and the ferocity of the bull thus manifested; second, the banderilleros, who act in the second stage of the fight and who, after three horses of the picadores have been gored, approach the infuriated bull and thrust into the back of his neck short barbed spears about a yard long, having curved points, so that having pierced through the skin they will hang there to the annoyance and irritation of the bull; third, capeadores, or cape-men, who with their long red capes tease the bull and with them attract his attention and call him away from attacking anyone who may not be able at the moment to defend himself.

Besides these one sees in the ring a number of 
I72 THE COURT OF HIS CATHOLIC MAJESTY menials wearing red flannel shirts; "sabios monos," or "wise monkeys," the Spaniards call them. These also appear in the procession following the bull-fighters "of the career." Last of all come the teams of mules, three hitched abreast. Jingling bells are fastened to their harness, and red and yellow tassels in great profusion dangle from it. They will drag the dead horses and the dead bull out of the ring at the close of each act. Around the entire inner circuit of the bull-ring passed this procession, and then all withdrew except two of the caballeros on beautiful white horses; for it had been arranged on this wedding day that the three bulls which were to be fought in the ancient and comparatively humane manner should be the first three.

A signal is given. One of the alguaciles rides up in front of the royal box. The Queen throws down the key of the bull-pen; he catches it in his hat and opens the door. Out rushes the savage animal, mad from his lack of food for twenty-four hours. He tries to attack the horses, but in the first three acts, fought according to the ancient rule, is warded off and is stabbed with the spears of the caballeros. Renewed attacks are made, but never once is the beautiful white horse touched. Sometimes it is horsemanship which saves him; sometimes it is defence with the spear. After the bull has been stabbed many times, the Queen gives a sign, the caballeros retire, and the professional matador enters and is given the task of despatching the now badly wounded and wearied bull. He approaches the royal box and kneeling, 
with one hand on his heart and the other uplifted to the Queen, in complimentary speech dedicates the bull to her as a votive offering or sacrifice. $\mathrm{He}$ is expected to kill it at the first or second thrust of the sword - a long, narrow, straight blade. The thrust must be between the shoulder blades and must reach down to the heart. The skill consists in getting the bull into a position where this can be done at the first thrust. If the matador kills his bull with dexterity he wins the applause of the thousands. Hats, caps, coats, and cigars are flung in to the ring for him by enthusiastic admirers (hats, caps, and coats to be returned), and the King or Queen to whom the bull has been dedicated gives him a handsome present. In this royal bull-fight one of the matadores, with characteristic Andalusian gallantry, dedicated his bull to the ladies in tendido No. IX, and, delighted with the compliment, they plucked the flowers from their hair and rained them down upon him.

Those who were "aficionados," devotees, of the sport told me that it was a "poor fight"; that the bulls acted as if they had been "doped" and some went so far as to say that this was intentional, so that the sensibilities of the Queen and of the foreign princes, who were not accustomed to these contests, might not be shocked, and that the bull-fighters were not up to their best form. All this and much more Francisco told me, and Francisco knew. Had he not seen almost every bullfight in Madrid since he was eight or ten years old? He had been employed for nearly thirty 
I74 THE COURT OF HIS CATHOLIC MAJESTY years in the Legation. In fact he was born in it. And the only request that he made was that I would secure for him a ticket for the royal bullfight. I knew that when Francisco said the bull-fight was a poor one he meant it, for from our box I had been able to see him in his seat during all the corrida, and there was never a smile of approval, never a trace of enthusiasm, in his face. His was a bored look. Francisco, I fear, was blasé in the matter of bull-fights. He even said that the horses which had been killed by the bulls were so handled that when gored they would not be disembowelled; that this was to spare the feelings of the foreigners. It was undoubtedly true, and it was a dreadful disappointment to some people.

If the bull-fighters did not do their best, they certainly did some thrillingly daring things, and all the matadores received as presents from the King and Queen cigars in morocco cigar-cases and gold and silver vest buttons set with precious stones. Nine bulls were killed, and although the first three were never allowed to touch the beautiful white horses which the caballeros rode, each of the other six gored three poor old decrepit horses to death before he was himself killed.

From the bull-fight we hurried home, dined, dressed, and hurried to the Royal Palace for the reception that was to have been the grand ball. Six or eight thousand people were there. Twice the King and the Queen, followed by all the members of the royal family and the visiting princes and princesses, passed through the long 
series of crowded salons, the people falling back just enough to leave a passageway for them; and this was a veritable reception, for the King and Queen stopped frequently and greeted and conversed with those whom they saw. The royal party first came into the throne room where the diplomats had assembled. The King was in good humor. "How are you?" he said to me. "I am glad to see you here to-night. I came near not being here myself," alluding to his narrow escape from death when the bomb was thrown; and then, without either show of bravado or sign of fear, he told me about the manner in which it had been thrown, and how it had exploded and caused death and destruction all around his carriage. The Queen was on her husband's arm as they passed through the salons. Her beauty called forth praise from everyone. She wore the closed diamond crown which had been one of the King's gifts to her. This and two other pieces of jewelry which he had given her were valued, it was said in the papers, at four hundred thousand dollars. Gifts of enormous value had been made to Queen Victoria by Maria Christina and the other members of the royal family, by the sovereigns and princes of nearly all the countries of the world, and by thousands of other persons.

Even without music the reception was most enjoyable. It was a pleasure to wander through salons filled with so many objects of art; it was interesting to watch the passing show, to see and to meet the celebrities who were there. Just before we of the Diplomatic Corps left, we were 
I76 THE COURT OF HIS CATHOLIC MAJESTY asked by the Introducer of Ambassadors to send to the Ministry of State on the following morning the blue tickets that had been issued to us for the gala performance at the opera that was to take place the following night. We were told that pink tickets would be issued to us in their stead. It was explained that two tickets had been stolen, and it was feared that they had fallen into the hands of anarchists who intended to throw a bomb during the performance. Police investigations seemed to unearth anarchists everywhere. So the next morning we took out tickets of a new color for this gala performance that might finish with a tragedy, for this opera that might end in death.

Nowhere, it seems to me, does the sovereign go about so little guarded as in Spain. I know something about the precautions taken for the safety of our presidents. Past experience shows that they are not excessive, - if sufficient. I was, therefore, strongly impressed by the way in which people, even on those very days when anarchists were known to be active, were allowed to approach near the King and Queen. Sunday morning there was a capilla publica in the Royal Chapel, a religious service to which the royal family go in state, the public being allowed to enter and to occupy the long gallery or corridor through which the princes must pass on their way from their apartments to the chapel. On this Sunday, when the doors were thrown open, a perfect wave of humanity swept in and rushed up the stairs and filled the galleries. Anybody could enter who wished, and 
through this crowd, for a distance of nearly five hundred feet, passed the King and Queen, the Queen Mother, and all the princes and princesses, foreign as well as Spanish. Anyone in the crowd could have touched them, so near they were. After the service they came back in the same manner and through a crowd no less great.

Sunday morning the papers published the news that on the previous afternoon, at a little village about ten miles from Madrid, a young man had entered the railway station to inquire about the trains for Zaragoza and Barcelona. His subsequent movements excited suspicion, and being unable to produce the cedula, a document of identification which all Spaniards carry, he was told by one of the Guardia Civil (State Constabulary) that he must accompany him before a magistrate for examination. He consented, and they started off on foot. They had gone but a few rods when the stranger suddenly pulled out a revolver and shot the guard dead, and then, without attempting to flee, he shot himself, dying almost instantly. He was supposed to be the anarchist who had made the attempt upon the King's life. Within a day or two this fact was absolutely established, although on that Sunday morning there was some doubt. But even with one anarchist dead, people who went to the gala performance that night were apprehensive. Perhaps he was only one of a band of conspirators, and if so, what better chance for the others of the band to avenge his death than in the opera house when so many royal personages would be assem- 
I78 THE COURT OF HIS CATHOLIC MAJESTY

bled. At any rate, there were very many anarchists, even if they were not all of one band, and what a bag of game to them must seem the gathering of princes representing almost every monarchy in Europe. I never knew people in as much fear as those who were to go to that performance. Some, indeed, stayed away, and one lady of the Diplomatic Corps, after kissing her children goodbye and driving almost all the way to the opera house, drove back home to kiss them again, thinking it might be the last time; then she came to the opera house prepared to meet her doom. Police precautions were many and apparent that night, and the fears were not realized, whether they were justified or not.

It goes without saying that the assemblage was of the most brilliant character. The diplomats, special and permanent, were in the boxes assigned to them at either side of the great royal box in the centre. With the permanent Diplomatic Corps were their wives, and with Mrs. Collier and myself was her sister, who, by the courtesy of the Introducer of Ambassadors, had been invited to accompany us to nearly all the festivities except the dinner at the palace and the wedding ceremony itself. All the official world, military and civil, were there, of course, with their wives and families. The beauties of the court were no less well represented at this performance than at the bull-fight the day before. From orchestra chairs to topmost gallery there was hardly a vacant seat; for those who had not dared to come had dared to give their tickets to others, 
who came in their places. Every man, of course, was in uniform or dress coat and nearly everyone was wearing some order or decoration, and every lady wore her finest gown and her most splendid jewels, and the opera house was decorated and trimmed for the occasion, garlands of flowers festooning the columns and flags draping the fronts of balconies and galleries and boxes. "Lucia di Lammermoor" was the opera. It was splendidly sung, but little appreciated, because other things were of greater interest that night. At a quarter past ten the royal party arrived. The band played the Royal March. The Queen, followed by the King, entered the royal box and repeated cries of "Long live the King and Queen!" "Long live the Queen of Beauty!" were heard. Then the others entered and took seats in the same box and in two others immediately adjacent, and next to those of the Diplomatic Corps. The opera was sung. Halberdiers stood like sentinels at each end of the stage, not for protection, but for show. No bomb was thrown, and everyone returned home in safety.

Early Monday morning hundreds of teams and carriages of all descriptions were going out of Madrid along the dusty highway leading to the manœuvre grounds at Carabanchel, six miles away, where was to be held the military review. Teams of four mules galloped along the road, pulling the carriages assigned to the princes and Special Ambassadors. Reviewing stands had been erected on the field. The troops were drawn up in two great columns, and when all the people had 
arrived, the young Queen, in her carriage drawn by four mules, came in sight. With the King on horseback riding at the side of her carriage, she passed down the lines of soldiers, who stood with arms presented in salute, and then she was escorted to the royal stand. The King then led his troops past. By special decree the Wad-Ras Regiment, because of its gallant conduct on the day of the attempt on the King's life, had been given the first place in the line of march. After the infantry came the artillery, and finally the cavalry in such a cloud of dust that they could hardly be seen. It was a day of almost intolerable heat.

Monday afternoon, in the Plaza de Toros, a concert was given by orfeones (choral societies) from all sections of Spain. It was a most interesting feature of the week's programme, for the regional songs were sung and the dances of all sections were danced; while peasants from nearly all the provinces, in their distinctive costumes, were much in evidence.

Monday night there was a grand ball in the house of the Duchess of Fernan Nuñez, head of one of the oldest and most eminent Spanish families and hostess, during the festivities, of Prince (now King) Albert of Belgium. In his domains on the banks of the Meuse the Duchess has a magnificent estate. Suffice it to say that no function was more brilliant and enjoyable than the ball in the historic palace of this lady. She did the honors with the help of her sons, the Duke of Montellana and the Marques de la Mina (at 
that time Master of the Horse) and their wives, who are not only ladies of the Queen, but who are justly renowned throughout all. Spain for their beauty, their grace, and their loveliness of character. All the princes and all the diplomats were at this ball, and the greater part of Madrid society.

Banquets and receptions were given throughout the week by most of the embassies and legations and by many of the Spaniards who acted as hosts of the foreign princes, or who had turned their houses over for occupancy by them, or who had been specially assigned to act as aids to the princes while they were in Madrid.

Tuesday night's festivity took the form of a military parade and an illuminated civic procession. Thousands of soldiers, mounted and on foot, marched through the streets bearing lighted lamps of many colors, some in the form of flowers. Illuminated floats of enormous size and showing great cleverness of conception and much beauty of design were borne, some on carts, some on the shoulders of the men. Crowns, shields, flags, portraits of the sovereigns, all brightly lighted, were carried in this parade and made a pleasing sight. The procession ended at the palace, where the King, with the Special Ambassadors, beheld it from the balconies. A concert was then given by the massed bands which had taken part in the parade, and at its close the Special Ambassadors were received in final audience by the King, preparatory to their actual departure from Madrid the next day. Wednesday afternoon the Battle of Flowers 
I82 THE COURT OF HIS CATHOLIC MAJESTY took place in the Park of Madrid. It had been carefully planned and was carried to a successful conclusion, but it lacked éclat because the Government vetoed the attendance of the King and Queen.

Thursday night Their Majesties tendered to the permanent Diplomatic Corps the dinner in their honor. All the Spanish royal family were present and the Princess Beatrice of England, the young Princes of Bourbon-Naples and of Orleans, and the princes of Bavaria. It was given in the grand state dining-room, one of the largest and most magnificent rooms in any palace in the world. We sat at a long table, a hundred or more of us. The King and Queen sat together at the same side of the table, the centre of the side of the table, and not the head of it, being in Spain the place of honor. Opposite them were the Queen Mother and Princess Beatrice. At the right of the Queen was the Infante Don Fernando; at the left of the King the Princess Frederica of Hanover. At the left of Maria Christina was the Infante Don Carlos, and at the right of Princess Beatrice, Prince Alfonso of Bavaria. The other princes, Ambassadors, Ministers, and their wives were seated according to their order of precedence. The guests gathered early in one of the salons. The Introducer of Ambassadors gave each person, lady as well as gentleman, a plan of the table and a numbered card showing where he or she would sit. Gentlemen were not asked or expected to escort the ladies to the table, although that is the universal practice in Spain at diplomatic dinners 
and dinners in private houses; but the King and the princes at this dinner gave their arms to the ladies of the royal family and the other princesses. When dinner was ready to be served the royal party appeared and, the King and Queen leading the way, passed into the dining-room, the guests following in any order they chose. There was but one rule: "Find your seat with the aid of your card; if it is beyond the seats of the King and Queen bow to them when you pass." It is needless to say that the cuisine was excellent and that the menu was choice and varied. Perhaps I ought not to use the French word menu. It used to be the custom of the court to print it in French, but pursuant to a recent decree of the King, it was then and thereafter printed in Spanish. There were ten courses and six wines. The table decorations and appointments were, of course, luxurious, and the service was faultless. I have read many accounts of the awfulness and the awesomeness of the formality of palace dinners at the Spanish court. It did not impress me in that way. It is true it was not especially jolly, although the King and nearly everyone else was hilarious when one of my colleagues, leaning back in his chair, broke the back of it and fell on to the floor. Bon-bons were served in small silver boxes that were given to us as souvenirs of the dinner, and each person carried home a piece of the wedding cake in a little satin-covered box, upon which was the photograph of the King and Queen. There were no toasts. The dinner passed off most pleasantly, although, I think, some of the 
I84 THE COURT OF HIS CATHOLIC MAJESTY

others that I attended in subsequent years were possibly a little merrier. After dinner the ladies of the Diplomatic Corps followed the ladies of the royal family into one of the salons, where all sat down and spent nearly an hour in conversation, the Queen and Queen Mother having one lady after another brought up to sit on the settee with them and to have a long personal conversation with each one. Meanwhile the men had gone with the King and the Infantes into the Hall of Columns, one of the large rooms of the palace, and for over half an hour they smoked, the King conversing with each person present.

Thursday afternoon was the date to which the King's birthday reception had been postponed. Ordinarily it would have been celebrated on the seventeenth of May. It was like all the receptions of the kind at the Court of His Catholic Majesty. I will describe them in a separate chapter because of their elaborate character. Just as always on these occasions, committees of the Senate and the House of Deputies came in their great state coaches to present their felicitations, and just as always, after they left, there was the large general reception when, for an hour or more, representatives of all branches of the Government and of every phase of national life passed in one continuous line before the throne to do homage to the sovereigns.

With this ended the long programme of festivities, ceremonies, and pageants which, beginning four days before the wedding, continued until eight days after it. Anarchy had shown its foul hand 
once, but the significant thing had been the almost universal enthusiasm of the people and their constant demonstration of their sincere wishes for health, happiness, and long life to the King and to his bride, their Queen. 


\section{CHAPTER X}

\section{A Gala Day with Reception}

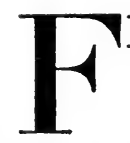

TIVE days of the year are marked in the Spanish calendar as dias de gala con recepcion, - gala days with a reception at the Royal Palace. These are the birthday and "name day" anniversaries of the King and the Queen, and the birthday anniversary of the Queen Mother. The latter anniversary falls within three days of her "name day" and consequently only one reception is held for the two events.

In all Catholic countries everyone has as his Christian name, or as one of his several Christian names, that of a saint, whom he regards as his patron or tutelar. This saint's day each year is, for all those having that name, a fête day of capital importance. The festivity associated with a birthday celebration among Protestants is not unknown in Spain, but far more joyous in that country is that which marks the observance by everyone of his saint's day or "name day," or, as the Spaniards almost universally call it, "his days." On that day presents are sent, calls of felicitation made, and notes of congratulation written. One is "at home" to all his friends. So strong is the feeling that clusters around "name 
day" that all those who have the same Christian name feel in a sense related, although there may be no kinship of blood. They are "tocayos" of each other. Great is the number of notes and cards they exchange with each other on this day. If, perchance, one bears a name so common as José or Juan, hundreds will be the missives of felicitation that he will send to the other Josés and Juans and hundreds will he receive in return from them. There is no excuse for forgetting the day when your friend celebrates. Does not La Sociedad, the Social Register of Madrid, give in the chronological order of all the saints' days the names of everyone in the haut monde arranged under their respective saints? Do not the columns of all the great papers daily contain in the notes of society such announcements as the following: "To-morrow, the day of San Ignacio, will celebrate their days, Their Excellencies, the Ambassador of Austria and the Minister of War, Señor Cortez; the Señor Marques of San Sebano, and the Señores and Señoras Alcala, Henares, Ayala, and Castellana"?

The name Alfonso is a modern form of Ildefonso, and all Alfonsos from the King down to the peasant celebrate on the day of this saint, who was an archbishop of Toledo in the seventh century and who was one of the most eminent scholars and theologians of the Middle Ages. When Princess Ena of Battenberg, born Princess Victoria Eugenia Julia Ena, was converted to the Roman Catholic, faith and decided to use Victoria as her name when she should become Queen, 
I 88 THE COURT OF HIS CATHOLIC MAJESTY

it was necessary for her to choose a saint. There are two saints of the name Victoria, and for a time there seems to have been a question which of the two to choose. Saint Victoria, virgin and martyr, whose day is celebrated on December 23, was finally chosen, La Epoca of Madrid stating that the day of this saint coming in the Winter rather than in the Summer, when the court is absent from Madrid, would make it more convenient to fête the day by the reception which annually ought to take place in the Royal Palace.

Thus it is that January 23, the day of San Ildefonso, and December 23, the day of Saint Victoria, as well as May 17, October 24, and July 2I, the birthdays of the King, the Queen, and the Queen Mother, are gala days with reception.

How does gala day find expression? In brilliancy of color. In the capital, and generally throughout the realm, every public functionary everyone who belongs to the court, everyone who serves the King, the State, the province, or the city, in high or low station, from the grandee on duty at the palace down to the concierge at the door, from the Captain General of the Army down to the latest recruit, from the Minister of the Crown down to the messenger of the Ministry, from the Master of the Horse down to the coachman in the royal stables - wears his most showy uniform or his gayest livery. The private puts a little plume in his hat and gloves on his hands; the Guardia Civil buttons to the front of his coat the white covering; the servant in the 
palace is in knee breeches and powders his hair, and in some way the dress of everyone indicates that this is an exceptional day.

How else does gala day find expression? In manifestations of patriotism and loyalty. In flags flying from all public buildings. In colgaduras draped over the balconies of the houses, displaying the coats of arms and monograms of their owners or the national colors. Gala finds its expression, also, in holiday recreation, in suspension of public business, and very likely in a grand bull-fight.

The five days mentioned are gala days with reception. We very properly translate the Spanish word recepcion by the English word "reception"; but let no one think that it is a reception such as is known in England or America. It is unlike the receptions of the President. No one, diplomats excepted, shakes hands or even speaks to the King. Neither are these receptions like "drawing-rooms," or "levees," in England, for no presentations are made except in the case of newly arrived secretaries and attachés of Embassies and Legations. In fact, these great institutions of the English court are unknown in Spain, there being no general court function at which presentations are made, this being usually done in private audiences in the morning or afternoon or very early in the evening, when one is received by the King or Queen in a small salon. There is no court dress for the occasion of these presentations. Men appear in uniforms or evening dress (if after six o'clock) or in ordinary frock 
I9O THE COURT OF HIS CATHOLIC MAJESTY

coats, and ladies in afternoon dresses. Very rarely presentations, by special permission, are made at balls or other social functions which Their Majesties honor with their presence, the presentation of foreigners being made by and only upon the request of the Ambassador or Minister of their country. The recepcion of gala day is, therefore, strictly not a reception. No one is really received except the Committees of the Senate and the House of Deputies and the Diplomatic Corps. The ceremony is rather one where the sovereigns receive the homage and obeisance of their subjects, a sort of review in which the representatives of every form of government activity pass before the throne, bow to the sovereigns, and receive in return, perhaps, a nod of recognition. The Spaniards used to call the ceremony besamanos (the kissing of hands). Long after that form of homage ceased to characterize it they used the word, but even the name is no longer applied to this ceremony, although kissing the hands of ladies remains still the cavalier's customary method of showing deference to them and is a part of Spanish etiquette.

Before I describe the recepcion, of which I never tired, although I participated in it often, let us consider some things which are preliminary, - a preface of it, if not a part of it, - and then let us see the scene of it.

Shortly before the reception the King and Queen are waited upon by committees from both branches of the Cortes, the Senate and the House of Deputies, who are received in person by Their 
Majesties and who read to them messages of felicitation to which carefully prepared responses are made. In Madrid, unlike London and Washington, each house of the National Legislature occupies its own palace instead of different parts of one building. The procession of the committees of the two co-legislative bodies, from their respective palaces to the Royal Palace and return, constitutes a small but brilliant pageant. In carriages of grand gala, of ancient make but made to last through the ages, gilded and decorated and upholstered in the most luxurious manner, drawn by horses in harness and trappings of richest design, and with coachmen and footmen in liveries of brightest hue and covered with gold braid, the committees of the two bodies make a brave show; and as carriages, liveries, harness, and trappings perpetuate the models and designs and patterns of years long gone, a picture of the past is flashed vividly into the present.

As the Committees of the Cortes are leaving the palace the official world which is to attend the reception begins to arrive. There are no ladies in the throng that comes, except the ladies of the Queen and the ladies of the Diplomatic Corps, who are received immediately after the general reception. Carriages are rolling toward the palace from all directions, - carriages of the Foreign Diplomats and of the Ministers of the Crown and of the Alcalde (Mayor) and of the Governor of the Province, distinguishable from others by the broad galons of gold, four inches wide, upon the 
I92 THE COURT OF HIS CATHOLIC MAJESTY

hats of their coachmen and footmen, and distinguishable from each other by the colors of the cockades. Hundreds of other carriages, big and little, public and private, are hurrying toward the palace, carrying other persons of lower official rank who will take part in the ceremony.

The Foreign Ambassadors and Ministers Plenipotentiary enter through the Plaza de Armas, the square within the palace yard, surrounded by the palace and its projecting wings and the Museum of Armory. Here, where the troops of the garrison which serve as the guard of the Palace are usually stationed; where the change of guard each morning attracts crowds of sightseers; here in what is practically a court of the palace, in which, however, on every sunny day in this land of sunshine hundreds of children play with as much freedom as if in their own backyards; here, on these gala days, are massed troops of all arms of the service, - regiments of infantry, batteries of artillery, and squadrons of cavalry; here too come thousands of the curious of Madrid to gaze in admiration at showy uniform, gorgeous dress, and military pomp and pageantry.

Up the grand stairway of the palace pass the members of the Diplomatic Corps, the Ministers of the Crown, and other high officials. The halberdiers who line the way pound on the floor with their halberds as Heads of Missions, Ministers of the Crown, "Grand Crosses," and others of very high rank reach them. This is a form of salute, a tribute of respect. James Russell Lowell was one of the most eminent Americans who 
filled the post of Minister to Spain. How much importance he attached to the observance of this formality is shown by his own statement that upon one occasion, having passed a halberdier who had failed to salute him by pounding on the floor in this manner, he (Mr. Lowell) returned, stood in front of him, and exacted this mark of deference.

The different classes or groups of those who are to take part in the reception assemble in various parts of the palace. The grandees in service, the Chamberlains of the Week, the "High Service," the Ministers of the Crown, and the gentlemen in waiting assemble near the apartments of the King. The rest of the official world who are to pass before the throne gather in another part of the palace. The Foreign Diplomatic Corps meets in a large salon adjoining the throne room, to which, a moment or two before the reception begins, it repairs, its members ranging themselves in a long line down the length of this great room, facing the throne. They stand in the order of precedence of the Heads of Missions. In accordance with the Rules of the Congress of Vienna, of 1815 , that famous gathering of diplomats at the close of the Napoleonic wars, the Nuncio of the Holy See has precedence over all his colleagues, Ministers or Ambassadors, no matter how long or short a time he may have been at his post. After him come the other Ambassadors, in their order of seniority of service at the post where they are then stationed. Then come the Ministers Plenipotentiary, likewise ranged 
I94 THE COURT OF HIS CATHOLIC MAJESTY according to seniority of service at Madrid, and then the chargés d'affaires. Back of each Head of Mission is grouped his staff of counsellors, secretaries, attachés, military and naval as well as diplomatic.

The assembled Diplomatic Corps, composed of the plenipotentiaries of all the nations of the world, European, Asiatic, and American, is a group that may well excite interest. Personal representatives of monarchs; spokesmen for sovereign States; statesmen of eminence in their own countries, educated, cultured, widely travelled, well informed, this body comprises the chosen representatives of the highest and best of each country. On these gala days, participating in one of Spain's most formal and most stately ceremonies, the members of the Diplomatic Corps - all except the American Minister, who is in full dress - are in uniforms no less splendid than those of Spain's, proud courtiers. Solomon in all his glory was not more gorgeously arrayed. The Nuncio, Archbishop of Heraclea, is in his purple robes; the Ambassadors, with their secretaries and attachés, are all in full uniform, swords at their sides, long plumed folding hats in their hands, orders, bands, and sashes decorating their coats; their military and naval attachés in the dress uniforms of their various regiments. The Ministers Plenipotentiary are in no less handsome uniforms and displaying almost as many orders and decorations: there is the Turk with his red fez; the Chinaman in his silken robes, his hair plaited in a long cue, and his hat sur- 
mounted by the little ball or globe of reddish colored marble, insignia of his Manchu rank. Verily the Diplomatic Corps constitutes a picture in color-kaleidoscopic in its variety and changing aspect.

The reception that is to follow is to be a brilliant spectacle. It needs to be fitly staged. Nothing is wanting in this respect. The scene is the throne room of the Royal Palace. In the beauty of its situation, its architectural excellence, its furnishings, and its collection of art objects, no palace in Europe is superior to this one and none but the Winter Palace at St. Petersburg can vie with it; and of all the superb rooms in this vast pile at Madrid none, in grandeur or magnificence, surpasses the throne room. It is situated in the centre of the principal part of the palace. From the five balconies opening out from it one looks down on the Plaza de Armas filled with troops, over the low wing where is installed the Royal Museum of Armory, across the thin silver stream of the Manzanares, above the forest of the Casa de Campo as far as the distant Guadarrama Mountains. Well may a Spanish king exult as he looks out on this extended prospect, sovereign of all that he surveys.

Within, the throne room is most magnificently furnished and most beautifully decorated. Gigantic rock crystal chandeliers hang from the ceiling. Colossal looking-glasses, from the once famous but long since abandoned factory at La Granja, San Ildefonso, mirror, reflect, and again reflect the other objects of this superb room, so 
I96 THE COURT OF HIS CATHOLIC MAJESTY

that its great length and width are seemingly increased and its furnishings infinitely multiplied. Crimson velvet hangings bordered with gold cover the walls; splendid inlaid marble tables are at the sides and ends of the room; richly gilded mouldings fantastically carved and of exquisite pattern frame the mirrors and windows and divide the ceiling into panels; mosaics of rare and variegated marbles give to the floor a beauty of design. All this combined makes a room without an equal in splendor. The ceiling, one of John Baptist Tiepolo's most boldly conceived and best executed works, is allegorical of Spain's greatness and represents the monarchy seated amidst the ancient gods and virtues and surrounded by Spain's dominions in both hemispheres. In the corners are delineated the provinces of the kingdom, while in gilded medallions in the corners Roberto Michel has painted the four seasons and the four elements. Statues of bronze symbolizing the functions of government stand around the room. Marble busts of ancient Roman emperors and of the heroes of mythology are placed on the tables.

Exactly in the centre of the long side opposite the windows is the splendid throne. Four steps lead up to it. At the corners are four life-size lions of silver covered with gold, each with its paw toying with a small globe, fit symbol of that Spain which in the time of Charles the Fifth and Philip II virtually dominated the world. Back of the two magnificent gold throne chairs, red velvet hangings bordered with gold cover 


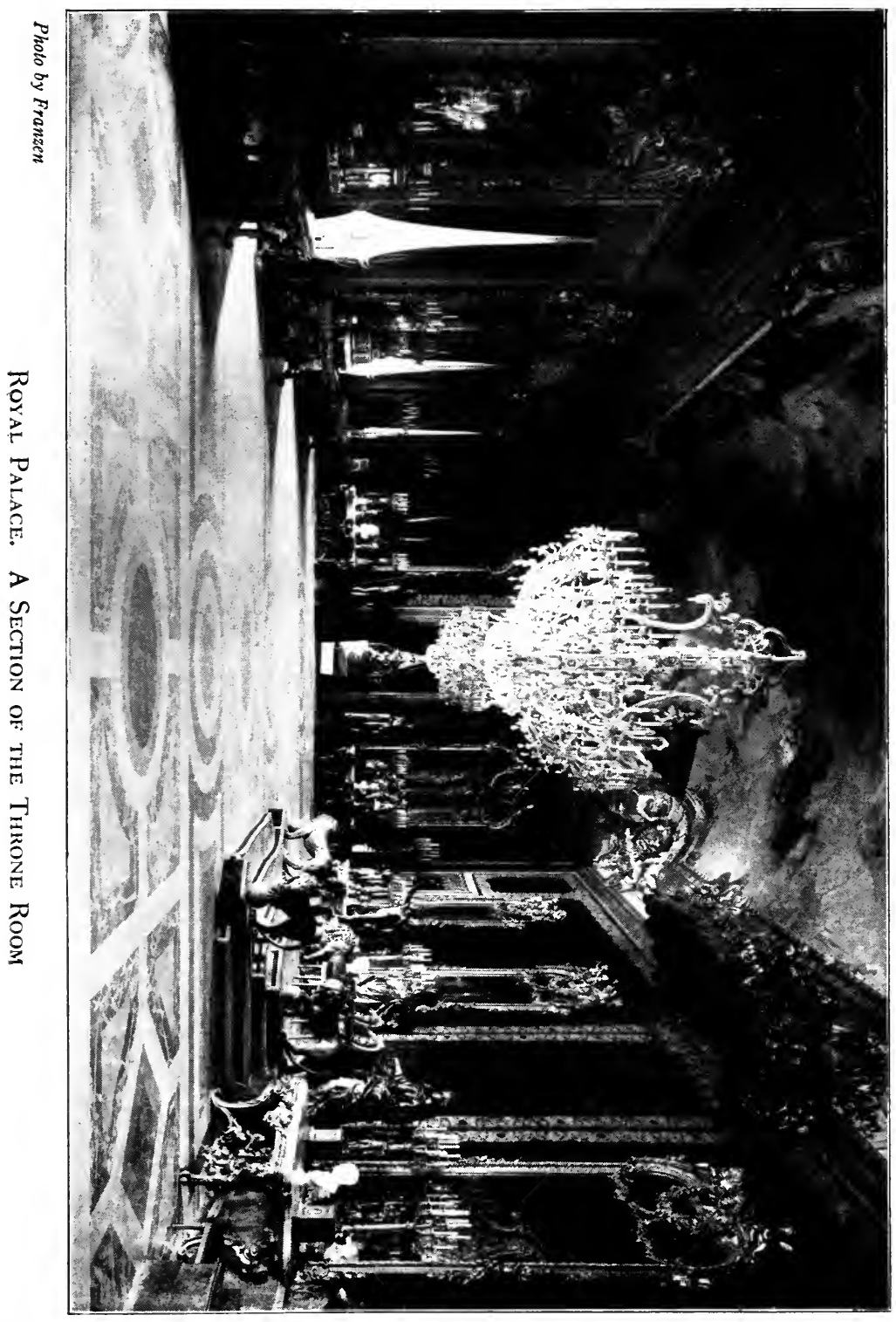




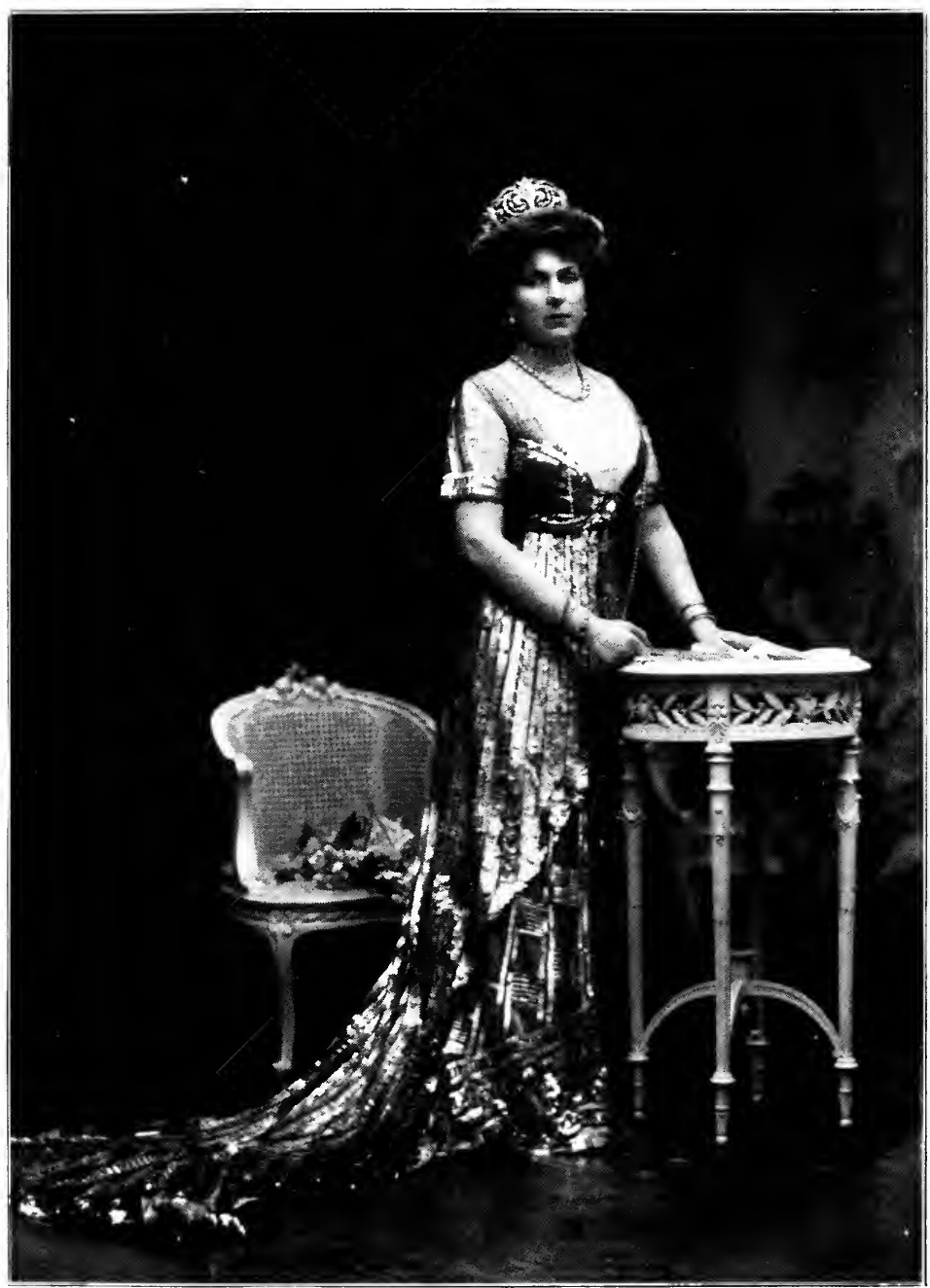

Photo by Kaulak

Her Majesty, Queen Victuria in igi 
the wall and reach from the richly carpeted floor to the canopy at the ceiling, - a broad, wide, crimson velvet canopy, heavily hung with golden tassels, heavily embroidered with golden cord. At each end of this long throne room is a door. Through one of these doors will enter and out of the other will pass the long stream of those who will this day do homage to their King.

It is the hour fixed for the reception. Suddenly the sounds of the Royal March are heard and Their Majesties approach the throne room attended by the Ministers of the Crown and by a great retinue of courtiers. In that showy parade one sees the Gentlemen of the House and Mouth discharging to-day their most arduous duties, although the title of their office indicates the service at the table and in the dressing-room of the King which their ancestors actually used to render; the Gentlemen of the Chamber; the Mayordomos de Semana, or Chamberlains of the Week, in their long scarlet coats flowing wide open, massed with gold embroidery; knee-breeches, frilled shirts, white silk stockings, and low shoes with broad silver buckles, and carrying the tiniest of canes in the right hand and a narrow sword fastened at the left side; the gentlemen in waiting "with service," and, grandest of all, the grandees of Spain who are Lords of the Bedchamber, each in uniform and each with his gold key fastened on the back of his coat over the right hip. Long is the list of all these members of the royal household who have a right to appear in this retinue. I have told in Chapter I of their 
number. By no means all are there this day, but the attendance is sufficient to form a large suite and their entry with the King constitutes a brilliant show; for it would be difficult to make uniforms and court dress of richer design or of brighter or more varied colors than those worn at the Court of His Catholic Majesty. Conspicuous in the retinue are the four Palace Chiefs: the Lord Chamberlain, the Lord Steward, the Master of the Horse, the General of the Halberdiers. Down the centre of the throne room passes this retinue of Lords and Gentlemen and Chamberlains, bowing from time to time to members of the Diplomatic Corps whom they know. Passing the throne, they take a place at the foot of it and to the right, where, throughout the reception that is to follow, they group themselves just behind the Ministers of the Crown and the Prime Minister, who usually stands during the entire ceremony with his hands resting on the head of one of the gilded lions on the steps of the throne.

The retinue of the King having preceded him as an escort, the King himself comes. Almost invariably he is in the uniform of a captain general. Round his neck are the insignia of the Golden Fleece. Tall, long of limb, he enters with a firm, measured, long step, - every inch a soldier, in every respect a king. Upon his breast sparkle and gleam the diamonds with which are set the various Spanish orders that he wears. Then comes the Queen, tall, matronly though youthful, queenly, beautiful, - no one now sitting on a throne more so, - wearing a crown of 
diamonds and strings of brilliants of matchless color and of great size. Her dress is of finest texture and of richest embroidery, especially the splendid court train several yards in length, which is borne by one of the Chamberlains of the Palace. The King and Queen ascend the throne and seat themselves. The Lord Chamberlain, the Master of the Horse, the Lord Steward, and the General of the Halberdiers stand back of them during all the reception. In the royal party, following the Queen, come all the Infantas, Maria Theresa, Isabella, Eulalia, and Louisa, - and all the Infantes, - Don Fernando, Don Carlos, and usually Don Alfonso of Orleans and Don Luis Fernando. Like the Queen, the Infantas all wear beautiful dresses with long court trains borne by Chamberlains, and each displays superb jewels, tiaras, necklaces, collars, rivières of diamonds and strings of pearls of rare beauty and of great value. Each, moreover, wears across the breast the purple and white band of the Order of Maria Louișa. The Infantas and Infantes seat themselves in massive gilded chairs which are placed on the floor at the foot of the throne and to the left of it, facing the Diplomatic Corps.

The Infantas sit in the order above mentioned, the order of the right of succession to the throne enjoyed by the first three. Yet those who are actually next in succession, the infant children of the King and the young children of the Infante Don Carlos and of the late Infanta Mercedes, are not there because of their tender years. And one other is not there, - Maria Christina, Queen 
Mother, who for sixteen long years sat in state upon the throne as Queen Regent and who, at first alone, and then afterwards with her little son, a mere child, seated alongside of her, received for him and in his name the same tribute of homage and respect which to-day is shown to him in person and to his royal consort. As Maria Christina has once sat upon the throne, it is felt that neither her own dignity nor the dignity of the crown should be impaired by her taking a place at the foot of it, and consequently she does not attend these receptions.

Back of the Infantas and Infantes are seated the ladies and gentlemen who are in attendance upon them, and the ladies of the Queen. Each of these is in court dress with train. All the gowns are of the same general design, but there is infinite variety of color. Each lady wears feathers in her hair and upon her breast a diamond-studded badge consisting of the monogram of the Queen, the symbol of her office as a lady of the Queen. About half of those now holding the position have been appointed since Queen Victoria came to Spain. Nearly half were appointed when Maria Christina was Regent and, therefore, wear the badge with her monogram as well as that with the monogram of Queen Victoria. One or two, like the Duchess of Fernan Nuñez, who was appointed in I859, have served under Queen Isabella, Queen Mercedes, Queen Maria Christina, and Queen Victoria, and bear the monograms of all four.

The royal persons and their retinues have all taken their places; the stage, as it were, is set. 
The performance, reception, ceremony, pageant call it what you will, view it in whatever light you like - is to begin. Through the door at one end of the room comes a procession which for one hour will file through that room, passing between the Diplomatic Corps on one side and Their Majesties and their retinue and the members of the royal family on the other. In single file the persons in that procession will come down the centre of this great room, until, immediately in front of the sovereigns, one by one, each will give a half turn, face them, and bow; then a step to the right, a half turn, and a bow to the Infanta Maria Theresa; another step to the right, another half turn, and a bow to the Infante Don Fernando; and then step by step to the right, turning and bowing to each member of the royal family; then turning into line each man passes out of the farther door, his tribute of homage paid, the reception over for him. Strictly a bow should be made to each member of the royal family, but even in this court of rigid etiquette there are many who make skips and not a few make one bow to the Infantas and Infantes collectively.

Occasionally the spectator sees a courtier whose bow, if bow it may be called, is peculiar. It is not a forward inclination of the head and body, but a quick jerky dropping of the body, with the knees bent forward, as if they were hinges. $\mathrm{He}$ is bowing in the way some remote ancestor did and in so doing is but exercising a special privilege conferred upon that ancestor and his descendants. In the midst of the ceremony the Infante Don 
Carlos, who is a brigadier general, and the Infante Don Fernando, who is a captain, will leave their seats, pass out of the throne room, soon to come in again with their respective commands, bow to the sovereigns and the others of the royal family and then take their seats, there to remain, until suddenly three young officers bow to them and the two Infantes rise and return the bow. Why do they rise? Because the three young officers are themselves princes, the younger brothers of the Infante Don Carlos, sons of Count Caserta, claimant to the throne of the now extinct kingdom of Naples.

And what recognition do the King and Queen give to those who come and by their coming testify to their loyalty to the throne and their adhesion to the monarchy? A slight nod, the merest inclination of the head, sometimes not as much as that. It may seem like indifference, but it should not be forgotten that there are hundreds bowing to the King and Queen and hundreds of bows by them in return might be fatiguing.

Who compose the throng that comes this day to honor the sovereigns? What of pageantry or of pomp is there in this procession before the throne? Why is it of such fascinating interest? What is there inspiring or stimulating in it? Before you, pass the men of power and authority, the men in office and in place, of a nation of twenty millions, once the mistress of the world. Here are the representatives of every form of government activity, - military, civil, ecclesiastic, educational. In uniform and in court dress, in 
doctors' gowns and in judges' robes, in bishops' vestments and in monastic cowl and hood, wearing orders, decorations, and medals, the outward sign of what they are or what they have done, they file by. There is variety; there is movement. Institutions founded centuries ago are brought before the eye; customs that date back to the earliest periods are observed; the bearers of titles associated with the most memorable events in the world's history pass before us; organizations, like the ancient military orders that fought in the seven centuries of warfare with the Moors, are there represented by their modern membership descended lineally from the ancient. This procession is, then, a picture of the Spain of to-day; but it is much more. It is a panorama, a moving picture of the centuries that have gone before. It is enough to fill a foreigner with admiration; it is sufficient to cause a Spaniard to thrill with pride.

First come the venerable members of the Council of State, a body with advisory powers, composed exclusively of former Ministers of the Crown. At its head, in the days of my residence in Madrid, was Don Cristobal Colon (Christopher Columbus), Duke of Veragua, Marquis of Jamaica, the last lineal male descendant of the discoverer of America. The grave judges of the Supreme Court, the highest tribunal, follow in their robes of black; then the Supreme Court of the Army and Navy, the High Court of Accounts, the Council and Court of the Military Orders, and the Court of the Rota, the chief ecclesiastical tribunal. 
204 THE COURT OF HIS CATHOLIC MAJESTY

Next in order come the Provincial Council of Madrid province and the Alcalde (Mayor) and the Ayuntamiento (City Council) of Madrid. These are in full dress rather than uniform, but nearly all of them wear medals or decorations. Most noticeable in the latter group, because of commanding height, perfection of physical development, ease and dignity of bearing, is Luis Mazzantini, Vice-Mayor, former matador and idol of the Spanish masses who flocked in past years to the bull-ring. No one in all that procession soldier, diplomat, or scholar - is more exact in his compliance with the etiquette of the occasion; no one walks, turns, or bows with more ease and grace.

Courts and Councils having passed, there come now the grandees of Spain, not covered (not officially installed and not Gentlemen of the Chamber), and their eldest sons. Gorgeous is the variety of uniforms displayed by them, each wearing that of some regiment, some order, or some service to which he belongs, but all being showy and brilliant. Former Ministers of the Crown then pass before us. Their number is very great, for cabinets are raised and overthrown in Spain like houses of cards. Tenure of office is uncertain and term of service is often very brief. But however brief it may be, even if only one day, the Minister draws a pension of fifteen hundred dollars per annum for the rest of his life, provided he does not draw any other salary from the Government.

The pomp and magnificence of the Church now appears, the Very Reverend Archbishops, those 
mighty prelates whose influence in Spain is so powerful. At their head is the Cardinal Primate, Archbishop of Toledo. They have hardly passed, clothed in their rich vestments, before the Knights Grand Cross of the great Spanish Orders of Carlos III and Isabella the Catholic appear with their broad bands, the former of blue and white and the latter yellow and white, crossing their breasts from right to left. Right Reverend Bishops come next. In their purple robes, with their gold crosses hanging by golden chains from their necks, their bishops' rings set with sapphires or other precious stones, they add to the color of this spectacle, while the distinction of their bearing impresses one with the importance of their rank and position in the Church and in the nation. Titles of Castile follow, that is, the marquises, counts, viscounts, and barons who are not grandees. Well for us who have to stand here to see this moving procession that only a few of the nineteen hundred persons who have these titles are here this day. The panorama moves on and now presents itself in its most brilliant aspect as the members of the four great military orders of Santiago, Calatrava, Alcantara, and Montesa file by in their beautiful white uniforms with their distinctive crosses of various forms and colors stitched to their coats. The Royal Guilds and the Knights Hidalgos of Madrid close this section.

The officials, bureau chiefs, and division heads of the various ministries and the corporate bodies attached to them next pass in line. First comes 
the secretarial force of the Prime Minister's office; then the Ministry of State with scores of its functionaries and the Commanders and Knights of the Orders of Carlos III and Isabella the Catholic, followed by the Sovereign Order of St. John of Jerusalem and the bearers of foreign decorations of all grades. The Ministry of Grace and Justice comes next. This is the department which does the work of our Attorney General and in addition supervises the affairs of the Church so far as they are affected by the State. What a mingling here of civil officials and functionaries with ecclesiastics! Following the UnderSecretary and other officials in full uniform come the representatives of the monastic orders, - monks with their heads shaven,'monks barefooted or in sandals, monks with brown hoods and cowls, monks in black, monks in white, Franciscans, Dominicans, Trinitarians, and many others. These soldiers of the Church move on only to give place to the Ministry of War, followed by the Ministry of the Navy, with their numerous staffs of officials and their legions of officers of all ranks from generals down to lieutenants, from admirals to commanders. What a show of uniform! Verily this is the glamour of military life! The Ministry of Finance comes next and the Ministry of Gobernacion (Ministry of Internal Government) with its staff of officials and also with the officers of that splendidly drilled organization of state constabulary, the Guardia Civil, handsomely uniformed.

Next comes the Ministry of Public Instruction 
with its officials and bureaus and divisions and with several bodies pertaining to it, such as the universities, with their doctors and professors in scholastic gowns. The Royal Academies of learning also accompany this Ministry and immediately after them the members of the Order of Alfonso XII. Well may we scan the faces of those in these two groups, for here we see those who are really distinguished in art, science, and letters. The names of many of them I have mentioned in Chapter II. Behind these come the functionaries of the Ministry of Fomento (Ministry of Development, - Agriculture, Public Works, Commerce, and Industry). Persons in the civil service or of the ecclesiastical profession who are not included in any of the ministries already mentioned come next.

The royal household now appears in line. With the exception of the lords in waiting, the gentlemen in waiting, the Chamberlains, and the few others who entered with the King and formed his retinue, all of its numerous officials and functionaries file by, in uniform and court dress, and do homage to the sovereigns. There you see the Gentlemen of the House and Mouth, the Gentlemen of the Entrada, the Monteros (Grooms) of the Chamber, and all that great throng of courtiers that constitute the Spanish court. Following them come all those of the royal household who render services of a more useful and less ornamental character, - the private secretaries of the King and Queen, in uniform; the secretaries of the Lord Chamberlain's office and those of 
208 THE COURT OF HIS CATHOLIC MAJESTY the Ward Room and of the Privy Seal, also in uniform; the four physicians of the royal house, in full dress, and then, in their priestly robes, the Honorary Chaplains; then, in superb uniform, booted and spurred, swords clanging at their sides, the four dashing equerries of the King. After these come the administrative force of the palace, the Grand Steward, the Intendente General, the Inspector General, the Royal Librarian, the Archivist, the architects of the palace, and the directors of the royal stables, of the Museum of Armory and those of all the institutions under the royal patronage.

Hundreds have passed already, but hundreds more are still to file by; for now march in the captain general of the first region (New Castile) and the general officers of the active service, as well as those of the reserve, followed by the garrisons of the region, down to the lowest commissioned officer. Every branch of the army is represented. Every kind of military uniform is seen.

The civil and court functionaries of the palace, as we have seen, have already filed by us. There remains yet the royal military household. They come last of all, fitting climax to all this pageantry; first, the halberdiers in their dress uniforms, halberds in hand; then, the pick and choice of modern Spanish cavaliers, the Escolta Real in their uniforms of spotless white, great top-boots, gold spurs, silvered helmets with long horsehair plumes. The Introducer of Ambassadors, in full uniform, and the Chamberlains of the Week, in 


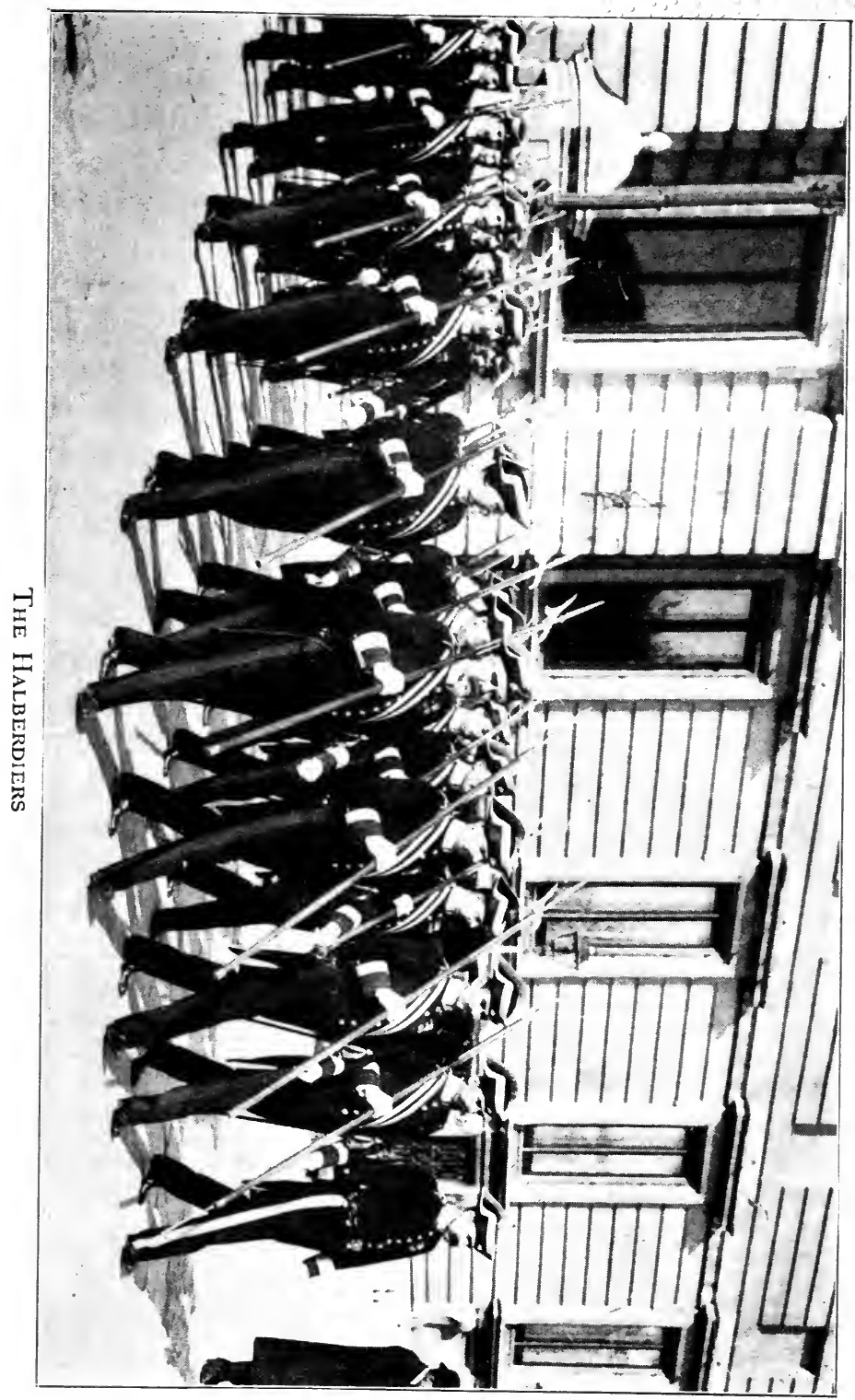


court dress, then fall in behind the others and close this long procession.

The King and Queen rise and descend from the throne and walk to the head of the line of diplomats. Accompanied by the Introducer of Ambassadors, the King passes down the line, stopping to speak for a minute or two to the head of each mission and to such newly arrived secretaries and attachés as may be presented to him by their respective chiefs, this being the only presentation of them which is made. Nothing better shows the versatility and the tact and the general range of information of the King than the brief but happy talks which he has on these occasions with the various foreign representatives. $\mathrm{He}$ is obliged, of course, to introduce the subject of conversation; and whenever he spoke to me or to any of my colleagues who were standing so near me that I could not help but hear, I was always surprised and favorably impressed by his acquaintance with the tastes and interests of the men with whom he was talking and by his knowledge of the latest occurrences in their several countries. Add to this the fact that he addressed nearly all in their native language, speaking with equal fluency Spanish, his own native language, German, the language of his mother, French, the language of the cradle of the Bourbons, and English, the language of his wife, and it must be admitted that, to use our Yankee expression, "He is a young man of parts." The Queen follows the King down the line, accompanied usually by the Second Introducer of 
2 IO THE COURT OF HIS CATHOLIC MAJESTY Ambassadors, she too speaking to each Head of Mission and to each secretary or attache who is presented to her, and she too speaking the languages that I have mentioned, having mastered Spanish after her coming to Madrid and speaking in it to the South American diplomats at the receptions before I left Madrid in I909.

Then the Queen makes a deep courtesy to the Diplomatic Corps, and the King, bringing his heels together with a sharp click, makes a quick soldier-like bow, and accompanied by the Palace Chiefs, the sovereigns pass into another room to receive the ladies of the Diplomatic Corps. The Infantas, in like manner, courtesying low to the Diplomatic Corps, pass out of the room, their long court trains borne by train-bearers. The Infantes bow and follow them, and then, two by two, the ladies of the Queen rise, advance slightly toward the Diplomatic Corps, courtesy, and pass out with the rest of the royal party. The reception is over for the men of the Diplomatic Corps.

Mingling, with the grandees and Chamberlains and Ministers of the Crown and Lords of the Bedchamber, without regard to rank or precedence, they wander toward the room where the reception of the ladies of the Diplomatic Corps is already nearly finished. These ladies, in their richly embroidered court dresses with splendid trains and sparkling jewels, drawn up in a long line in one of the salons, form a picture of elegance and beauty. They stand in the 
order of precedence of their several Embassies and Missions. For many years the wives of secretaries and attachés stood behind the wives of their chiefs, just as their husbands still stand behind their chiefs. But in recent years this has been changed, and now they stand in line with the others, but below the wives of Ministers and chargé d'affaires, a concession made to them so that they may better display their court dresses. Verily, the dressmaker shapes the world and rules the court. One other difference exists between the arrangement of the line of the Diplomatic Corps and that of their wives. All newly arrived ladies of the Corps who are to be presented stand next to the doyenne and are presented by her and not by their chief.

At the Spanish court no member of a diplomat's family except his wife has any court standing. Even adult daughters of widowers, Ambassadors and Ministers, notwithstanding they may be the social heads of their fathers houses and in their homes receive and entertain for them, are not put on the diplomatic list and they never attend the reception accorded by the sovereigns to the Diplomatic Corps nor sit with it on any ceremonial occasion. They are usually presented to the Queen and to the Infantas in private audiences. A request of this kind would never be denied, but their presentation would be the same as that of any private person to whom the same favor might be conceded.

During the reception of the ladies of the Diplomatic Corps, the King and Queen pass down the 
2 I2 THE COURT OF HIS CATHOLIC MAJESTY

line, speaking to them in the same way they have spoken to the men of the Corps, and then the ladies of the Corps and the Queen courtesying to each other and the King bowing, Their Majesties withdraw, and the reception is over for all the official world.

But the King and Queen now preside over another ceremony in which the Chiefs of the House and the actual servants of the palace, whose fidelity and attachment and devotion are doubtless no less strong and sincere than that of the official world who with so much state have filed past the throne, pass before Their Majesties in one of the salons and, following the traditional custom, render homage to them by performing the ancient ceremony of the besamanos, the actual kissing of hands.

While several thousand people in Madrid have thus, in this reception, testified to their adherence to the monarchy and have rendered homage to the King and Queen, thousands in all parts of the realm have done so by sending telegrams of felicitation to Their Majesties, and many more thousands in the capital itself by going in person to the palace and writing in the book set apart for that purpose.

The gala day in Madrid closes with a grand state dinner at the palace, at which the Ministers of the Crown, the highest court officials, a very limited number of the grandees and a few of the generals and admirals of the highest rank sit down with the members of the royal family at a table beautifully adorned, brilliantly illumi- 
nated, and sumptuously laden with choice viands and rare vintages, while the famous band of the Royal Corps of Halberdiers discourses its finest selections. With this ends the gala day with reception. 


\section{CHAPTER XI}

\section{The Imposition of the Cardinal's Biretta}

\section{HE Sacred College of Cardinals of the}

Roman Cathofic Church is limited in number to "seventy. Its imembershihp is, however, rarely, if ever, full; and even when the 'Pope at a consistory creates new cardinals, several vacancies are often left. "At all times the great majority of these, princes of the Church are Italians; yet rarely is there a country with a great Catholic population which has not at least one of its hierarchy in this powerful body which counsels the Pope in the affairs of the Church, directs its destiny after his death, and in solemn conclave elects his successor to the throne of St. Peter. In modern times generally from three to five of the great prelates of Spain are always found in the membership of the Sacred College. Usually they are the archbishops of Toledo, Santiago, Burgos, Barcelona, and Seville. Besides these there are often Spaniards who have no ecclesiastical jurisdiction in Spain, but who have, nevertheless, received this, the highest dignity of the Church; as, for example, at the present time that very able, learned, distinguished, and masterful man, His Eminence Raphael Cardinal Merry del Val, Papal Secretary of State, 
who, by virtue of his office, formulates the policy and directs the negotiations of the Vatican with foreign nations; also Cardinal Vives y Tuto, general of one of the great monastic orders, four of which, by papal regulation, must always be represented in the Sacred College. It is furthermore not uncommon for the Pope to confer the cardinal's hat upon his diplomatic representatives, his nuncios and pro-nuncios in foreign capitals, this being the guerdon awarded them at the close of long and eminent diplomatic careers, like the batons which kings give to the field marshals who have, as generals, conducted for them successful campaigns or won great victories.

The ceremonies at Rome and the solemn services connected with the creation of cardinals and their subsequent reception into the consistories are outside of the scope of this chapter, which is limited to the part which the King of Spain is often called upon to play when one of his subjects or the Nuncio accredited to his court is created a cardinal.

The insignia of a cardinal are several. First, there is the hat, a low-crowned, broad-rimmed hat of red, with silken cords, yards long, running from its sides, the cords interlaced and loosely knotted, and fifteen tassels hanging from each, arranged like the letter $A$; that is, one tassel nearest the brim of the hat; then below it, two; below that, three, and so on until the fifth row contains five. In the popular mind this wonderful creation is the distinctive badge of the cardinal, and the expression "to receive the hat" is 
equivalent to "to be created a cardinal." The distinctiveness of the cardinal's dress - which is a long cassock or soutane buttoned in front down to the feet-lies in its color of cardinal red. By ancient rule the train of this may be seven yards in length. The cassock of the Pope is white, that of a bishop purple, and that of a priest black. Cardinals who belong to the religious orders do not, however, wear the cassock of red, but one of the color of their monastic habit. Over the cassock the cardinal wears, as do ecclesiastics of nearly every rank, a rochet, and over that a short purple cape. The cardinal's hat which has been described is so large and so heavy that it is rarely, if ever, worn. In life it is guarded and prized by the prince of the Church as the symbol of his dignity; after his death it is hung from the ceiling of the church or cathedral, in front of his tomb, like a trophy or a coat of arms. In addition to this covering for the head, the cardinal has another which is also distinctive of his rank; namely, the red cap, or biretta, a square, rimless, close-fitting cap with four horns or projections from its four sides, running up to the centre and uniting at the top. Besides this he also has a close-fitting skull-cap, called by the Spaniards the birretina. All these, like the cassock, are of cardinal red, and their possession implies the cardinalitial dignity.

When a newly created cardinal does not live in Italy it is the practice of the Pope to send the biretta to the sovereign of the country to be by his hands placed upon him. Great formality 
characterizes the despatch of the cap from Rome; and in Spain the act of its imposition upon the head of the cardinal by the King is marked with all the splendor and stateliness with which the court of that country observes its ceremonies, especially those in which the greatness of the nation is glorified in connection with the power of the Church, with which its whole life is so intimately interwoven.

In 1907 it was my privilege to have two opportunities to see this ceremony, when cardinals' birettas were imposed by King Alfonso XIII upon the heads of the Papal Nuncio, Cardinal Rinaldini, Archbishop of Heraclea, and upon Cardinal Aguirre, Archbishop of Burgos.

The actual bearer of the biretta from Rome is usually a member of the Noble Guard of the Pope or one of the chamberlains of the Vatican. But to give the act greater éclat there is always a special mission. Either someone is sent from the Papal Court as an ablegate or else some Spanish prelate or someone connected with the Nunciature is so designated. The last mentioned method was adopted in 1907, when the Pope designated as ablegate Monsignor Sibilia, Auditor of the Nunciature (Counsellor of Embassy) at Madrid (now Papal Internuncio in Chile), a person whose charms and graces and whose successful work in the diplomatic service of the Holy See give every assurance that he will eventually attain the highest rank in the Church.

The mission of the ablegate is not to place the biretta upon the head of the cardinal, but to deliver 
to the King the papal brief requesting and authorizing the latter to do so. For this purpose the ablegate, like an ambassador on extraordinary or special mission, needs letters credential, and indeed, no ambassador goes forth armed with so many letters - all of them, in diplomatic effect, credentials - as does the ablegate who is sent on such a special mission to a Catholic court; for he bears letters from the Pope to the King, the Queen, the Queen Mother, and even to the Infantas, and also letters for the same persons despatched by the Cardinal Secretary of State. All these are written in Latin. More than half a century ago, upon the arrival of one of these special missions at Madrid, a question of awful import arose. Should the ablegate be presented to Their Majesties by the Nuncio, the Pope's permanent representative, or by the Minister of State? The mountain labored long and brought forth this decision, which may be found in the Practical Guide of Diplomacy: "By the Minister of State; because the ablegate comes bearing eight letters of credence, while the Nuncio bore but one." Great is the Nuncio, dean of the Diplomatic Corps; great are his power and prestige. The decision of the Spanish court in the case just cited does not belittle his position. It only shows the importance attached to the ablegate's mission and to the ceremony of the imposition of the biretta by the King upon the new cardinal.

The ablegate makes the same call upon the Minister of State as do all other newly arriving diplomats. He is received in audience by the 
sovereign and presents his credentials and makes the usual calls of ceremony upon the members of the permanent Diplomatic Corps. The date is then fixed by the King for the solemn ceremony of the imposition of the biretta. In what follows I shall describe that which I saw and heard on the occasion when it was placed on the head of my diplomatic colleague, Cardinal Rinaldini.

The ceremony took place in the Royal Chapel of the palace, which, on the appointed day, was filled with the brilliant assemblage of statesmen, soldiers, nobles, diplomats, ladies of the Queen, ladies of the Diplomatic Corps, who are the usual attendants at these and all other similar ceremonies, such as the marriages of Infantas, the baptismal services of princes, and the presentation of the golden rose.

At the appointed hour strains of music were heard. Accompanied by all the court and by a military escort, the King, in uniform and with the usual decorations and orders, and the Infantes, also in uniform and wearing their decorations, and the Infantas in court dresses with long trains, and wearing their richest jewels and displaying also the orders to which they belong, traversed in state the long galleries that connect the royal apartments with the Royal Chapel. The retinue of the royal party was the usual one,-gentlemen in waiting, Chamberlains of the Week, Lords of the Bedchamber, grandees, and the Palace Chiefs. This time, however, one saw in it the Papal Guard, the bearer of the cardinal's cap. Accompanied by the Introducer of Ambassadors, he was a striking figure 
in his white breeches, top-boots, bright red coat, and shining helmet with its high gilded crest and its pompon of black and white and the long horsehair crinière flowing from it down his back below his shoulders. Across his breast were the bands of military orders to which he belonged, and he wore many other decorations.

The royal party and its retinue made its solemn entry into the chapel. The King took his place upon the great gilded throne, placed on a raised dais, under a canopy of velvet fringed and hung with tassels of gold. Velvet hangings, too, covered the wall back of this throne and reached from the floor to the canopy, and they were enriched and adorned with heavy gold embroidery. The Queen was not present because of the delicate condition of her health, but the Infantes and Infantas occupied their seats of honor. The Queen Mother, who had come to the chapel attended by her own personal retinue headed by the chiefs of her own house and by her own ladies in waiting, was in her specially designated tribune. Her dress and her jewels were of richness, elegance, and perfect taste. Her bearing was that of one of supreme distinction. Worthy is she of her proud lineage, this great-great-granddaughter of the great Empress Maria Theresa, and as she is royal and imperial in blood, she is no less so in her qualities of mind and heart; for she is a pattern of noble womanhood and the model of devoted mothers. As she entered the chapel that day, everyone in the assemblage paid to her a silent but sincere tribute of respect. 
In the chancel or presbytery, in their seats of honor, were, the great prelates. The Nuncio, titular Archbishop of Heraclea, who was to receive the insignia of his new rank as a prince of the Church, was dressed in the purple vestments of a bishop, which before the close of that service, after he had received the cardinal's cap, he was to lay aside in order to put on the cassock of red. In the chancel on that day were also the bishops of Madrid, Zion, Salamanca, and Jaen. Near them was the ablegate, Monsignor Sibilia. There, too, was the papal guard, actual bearer of the biretta. But he was not sitting. Throughout the entire service he stood, tall, erect, motionless as a sentinel, facing the King. At the altar was a throng of chaplains, priests, and acolytes.

The ceremony commenced with the reading of the pontifical brief in Latin, in which His Holiness empowered the King to place the cap on the Cardinal's head. The ablegate handed the brief to the King; the King handed it to the Bishop of Zion; the latter, in turn, handed it to the ecclesiastical notary, who with loud voice read it. Then advancing before the King, the ablegate delivered a most eloquent discourse in Latin. Addressing His Majesty as "Señor," he declared his inability to express fitly his pleasure in "appearing before the august throne of Your Catholic Majesty so splendidly surrounded by the royal family and by prelates, high officials, grandees of Spain, and diplomats, as the bearer of the cardinal's cap, by the paternal benevolence of the Supreme Pontiff, Pius X, destined to the 
222 THE COURT OF HIS CATHOLIC MAJESTY

Most Eminent Señor Aristides Rinaldini, Archbishop of Heraclea, Apostolic Nuncio of His Holiness in this court, and my venerated chief." Then, paying a most eloquent, sincere, and deserved tribute to the talents and to the noble qualities of that chief, to his "rare prudence in the conduct of grave and difficult negotiations, as well as to his profound humility in private life, that sublime virtue which is the mother and robust nurse of all other virtues," he continued, addressing the King:

"This being so, there remains for me, Señor, only to ask Your Majesty, with the most profound respect, that Your Majesty deign in the august name of the Vicar of Jesus Christ, to place, with your royal hands, upon the head of so illustrious a man as the Most Eminent Señor Rinaldini, the symbol of the highest dignity, which I present to you."

The new cardinal-elect then arose and in Spanish read his speech:

"Señor, in considering the most high dignity of Prince of the Holy Roman Church, to which, without taking into account the littleness of my merits, the kindness of the Common Father of the Faithful has willed to elevate me, I experience a keen emotion, especially upon seeing myself before the throne of Your Majesty to receive from your royal hands the solemn investiture."

In language of rare beauty and power and richness of metaphor and with manifest feeling, he reviewed at length the cordial relations between himself and the royal family during the seven years that he had been Nuncio at Madrid, and he alluded to the expected birth of the Prince of Asturias, heir to the throne (which occurred less 
than three weeks later), and to the arrangements then already made that he in representation of the supreme hierarch of the Church would have the honor, as the crowning glory of his mission, to act as his godfather at the baptismal font. Then with courteous expressions of "humble thanks to His Majesty and to Her Majesty the Queen Doña Maria Christina and to all the royal family, whose august presence so much exalts and magnifies the splendor of this function in which has been conferred upon me this sublime honor of Prince of the Catholic Church," and invoking the favor of "the God of supreme power and infinite wisdom that he be pleased to bestow every blessing upon Your Majesties, on the royal family, and on this highborn and illustrious Spanish nation," he closed his speech and advanced toward the King, who placed the cardinal's cap upon his head. The Cardinal then retired from the chapel to the sacristy and, divesting himself of his bishop's robes of purple, dressed in his new robes of red, reëntered the chapel, approached the throne, and was embraced and congratulated by the King.

The service of the mass then followed, and at its close Their Majesties returned in state to their apartments, while the new Cardinal repaired to the camara, one of the largest rooms of the palace, and there received the hearty and sincere felicitations of his colleagues of the Diplomatic Corps, by all of whom he was held in the highest esteem.

Such is the public ceremony; but for the sovereigns and the Minister of State there still remains the duty of making formal state reply to the 
letters brought by the ablegate from the Holy See. These replies may differ a little each time, but all are of one general tenor, notwithstanding those from the sovereigns to the Pope are supposedly, "in their own hand and of their own composition." The letters of a quarter of a century ago serve as good models and are publicly printed in the "Guia Practica del Diplomatico Español." Those to the Cardinal Secretary of State are like the similar ones sent on the occasion of the gift of the golden rose. Those from the sovereign to the Pope and from the Minister of State to the Pope may be of interest because of their form and their phraseology, even if their contents only repeat the information we already possess.

Letter of His Majesty, the King (Alfonso XII), to His Holiness, upon the occasion of the imposition of the cardinalitial biretta.

Most Holy Father:

I have received from the hands of Monsignor —-, Your Holiness's private chamberlain, the brief of Your Holiness which serves him as a credential as Apostolic Ablegate commissioned to bring the cardinalitial biretta for the Very Reverend Archbishop of - , created Cardinal by the benignity of Your Holiness.

I most heartily thank Your Holiness for this new proof which you have given $\mathrm{Me}$ of your paternal solicitude, not only by this nomination, but also by the commission which Your Holiness has been pleased to give $\mathrm{Me}$ of placing the above-mentioned insignia upon him who has been newly raised to this exalted dignity. For My part I have taken pleasure in doing my utmost to give to Monsignor the most favorable reception, as merits so well an Apostolic Ablegate of such distinguished and commendable talents, and on such auspicious occasion I take pleasure in being 
able to reiterate to Your Holiness the expression of the sentiments of My filial and sincere affection and the assurance of the fervid supplications which I address to the Almighty to preserve for many years to come the precious life of Your Holiness.

Given in the Palace of Madrid on the day of 1884.

Most Holy Father, of Your Holiness

the most humble and devoted son,

Alfonso.

To the Supreme Roman Pontiff,

Common Father of the Faithful.

Letter of the Señor Minister of State to His Holiness upon the occasion of the imposition of the cardinalitial biretta.

\section{Most Holy Father:}

With the veneration properly corresponding to the special favor for which I am debtor to Your Holiness, I received the brief which, upon his arrival at this court, was handed to me by Monsignor — - Apostolic Ablegate, commissioned by Your Holiness to bring the cardinalitial biretta of the Most Eminent Señor Archbishop of -

The benevolent sentiments which Monsignor, the Ablegate, expressed to me in the name of Your Holiness were received by me with the most respectful gratitude. For them I am indebted exclusively to the graciousness of a veritable Father.

Profoundly realizing that on so happy an occasion it was my duty to furnish Monsignor - the means of fulfilling honorably and worthily the important mission which Your Holiness had entrusted to his ability and illustrious zeal, I have had genuine satisfaction in contributing to it in every way within my power.

In having the honor to answer the letter which Your Holiness has deigned to address to me and for which favor I give to Your Holiness most humble and expressive thanks, I avail myself of the opportunity to assure Your Holiness 
226 THE COURT OF HIS CATHOLIC MAJESTY of my filial and respectful obedience to Your Sacred Person and to ask that you grant me the Apostolic benediction.

May our Lord spare the precious life of Your Holiness many years.

Madrid, the day of 1884 .

Most Holy Father, of Your Holiness the most humble and devoted son,

To the Supreme Roman Pontiff,

Common Father of the Faithful. 


\section{CHAPTER XII}

The Birth and Presentation of the Prince of Asturias

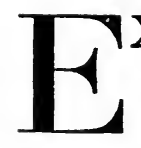

IXPECTATIONS of interesting events in families of all ranks are discussed in Spain with a freedom which their importance warrants, but which is not customary in America. Where the expected newcomer is royal, publicity must needs exist. Four months before the birth of a child to the Queen, the Minister of State formally communicates that important fact to the diplomatic representatives of Spain in foreign countries. One month prior to the birth, due and detailed statement of the Queen's condition is published in the official journal, La Gaceta, in which "the Most Excellent High Chief of the Palace, Lord Chamberlain of His Majesty, transmits to the Most Excellent President of the Council of Ministers" certain information which the medical faculty of the royal chamber has received from the physician of Her Majesty as to a certain important event which will occur within that month. Spain's Ambassadors and Ministers are again duly notified, and final preparations are made in Madrid. His Majesty the King forthwith decrees that "the prince or infanta to whom, with the 
aid of the Almighty, My beloved spouse shall give birth, shall be decorated; if a prince, with the collar of the Distinguished Order of the Golden Fleece, and with that of the Royal and Distinguished Order of Charles III, and with the Grand Crosses of Isabella the Catholic and of St. John of Jerusalem; but if the child be a princess, with the band of the Noble Ladies of the Order of Queen Maria Louisa; which insignia will be placed upon him or her by $\mathrm{Me}$ as soon as the child may have received the sacrament of baptism."

A royal decree is likewise made, providing for that interesting ceremony, now peculiar to the Court of His Catholic Majesty, the presentation of the newborn prince or princess immediately after birth. Documents in legal phraseology are not always interesting reading, but nothing can give a better idea of the character of this ceremony, of the many formalities surrounding it, of the elaborate and detailed preparations made in advance, and of the scrupulous care with which everything is arranged, than this decree as published in La Gaceta and as communicated to the officials whose duty it is to see to its execution. In that official journal we read as follows:

His Majesty the King (whom God guard) has been pleased to issue the following decree:

In order that the ceremonies which should take place on the occasion of the approaching confinement of My dear and beloved Wife, if the All-Powerful permits this happy event to be realized, may be verified with all the customary solemnities,

I decree the following: 
Article I: There shall be present at the presentation of the Prince of Asturias or Infanta who may be born, the Ministers of the Crown, the Chiefs of the Palace, the President of each of the two Co-legislative Bodies, the Commission from Asturias, a Commission of two individuals named by the Deputation of the Grandees, the Captains General of the Army, the Knights of the Illustrious Order of the Golden Fleece, a Commission of two individuals from each one of the Supreme Assemblies of the Royal Orders of Charles the Third and Isabella the Catholic, another of an equal number of individuals from each one of the Venerable Assemblies of the Illustrious Military Order of St. John of Jerusalem in the language of Aragon and Castile and the four Military Orders, the President of the Council of State, the President of the Supreme Tribunal, the President of the Exchequer of the Kingdom, the President of the Supreme Council of War and the Navy, a Commission of two individuals from the Supreme Council of the Rota, the Archbishop of Toledo, the Bishop of this Diocese, the Senior Chaplain of the Palace, all those who have been Ambassadors, the Chief of the General Staff of the Army, the President of the Technical and Advisory Bureau of the Navy, the Captain General of New Castile, the Civil Governor of the Province of Madrid, the President of the Provincial Deputation of Madrid, a Commission of two delegates of the same named by the Deputation, the Alcalde President of the Municipal Government of Madrid, a Commission of two members of the said Municipal Government named by the Municipal Corporation, a Commission of the Cathedral Chapter of the Diocese, the Directors and Inspectors of War, and the Commandant General of Invalids, and a Commission of the Collegiate Body of the Nobility.

Article 2: There shall be invited to be present at the same ceremony the foreign Diplomatic Corps with whom shall attend the Introducer of Ambassadors.

Article 3: As soon as appear signs indicating the approach of the confinement, the persons above designated shall be advised in order that they may all gather in uniform in the apartments of the Palace destined for this purpose. 
Article 4: As soon as the birth has occurred the Grand Mistress of the Robes shall immediately inform the President of My Council of Ministers, who shall announce to the persons present the happy event, giving notice as to the sex of the newly born, and he shall communicate it to the Captain General of Madrid and to the Commandant General of Halberdiers, in order that they may with all possible speed give the signal and the salutes of which the following article treats.

Article 5: In order that the people of the Very Heroic City of Madrid may know immediately if the newly born is a Prince of Asturias or an Infanta there shall be displayed, in the first case, the Spanish flag on that part of the Palace called the Point of the Diamond, and there shall be fired a salute of twenty-one guns in the customary place; in the second case, the flag shall be white, and there shall be fifteen guns. If the birth occur at night there shall be placed at the foot of the flag a lighted lantern of the same color as the flag.

Article 6: Accompanied by the Grand Mistress of the Robes and by the Chiefs of the Palace, I shall present the newly born boy or girl to the foreign Diplomatic Corps and other persons assembled in the Palace in virtue of the present decree.

Article 7: The Minister of Grace and Justice, as Chief Notary of the Realm, shall draw up the record of the birth and of the presentation which this ceremony shall constitute.

Article 8: The present decree shall be communicated by the President of the Council of Ministers to all the Ministries and to the High Chief of the Palace for its exact fulfilment.

Given in the Palace the third day of April, nineteen hundred and seven.

Alfonso.

The President of the Council of Ministers, Antonio Maura y Montaner.

Other preparations are made. From various parts of Spain certain sacred relics are sent to the 
Royal Palace to be placed in the Queen's room during the time of her accouchement, in accordance with customs that are centuries old. Among these relics are the arm of John the Baptist and the girdle of the Virgin from Tolosa. The latter is handed to the Queen at certain critical moments, and a prayer, while it is held in the hands or being kissed, insures a safe and happy delivery.

The attending physicians were the regular medical faculty of the royal household (four in number) and a private physician who had accompanied the Queen from England. These seem to have gotten along more harmoniously than on certain historic occasions in the past when the regular staff showed the greatest professional jealousy of the "stranger." Quarrels have been known in years gone by which have resulted in some ludicrous compromises. On one occasion, within a generation, the head of the medical faculty finally consented that the private physician of one of the queens who was about to give birth to a child might be present and might aid in ushering the newborn child into the world, taking it by the left hand, but he insisted that his prerogative should be recognized and that he should give the right hand. There is an ancient rule in Spain that if one of the princesses is about to have a child, the surgeon of the regiment to which her husband belongs shall be her attending physician. It matters not that the princess prefers some other physician; it matters not that the surgeon may notoriously be much more skilful in amputating a leg than in assisting at the birth 
232 THE COURT OF HIS CATHOLIC MAJESTY of a child. No princess would dare to go counter to this established rule. Her husband's position in his regiment would be rendered insupportable, and even the whole army would become disaffected. Compliance with this rule on more than one occasion has resulted disastrously to both mother and child, if current reports are to be believed.

The accouchement of the Queen had been expected daily from the tenth of April. It did not, in fact, occur until the tenth of May. It would not be far from the truth to say that during those thirty days the diplomats, who had received from the Introducer of Ambassadors a formal request to keep themselves "prepared, and kindly to attend at the palace as soon as the proper notice may be given," slept with their uniforms at the sides of their beds, ready, like firemen, to jump into them and start off at the first call. Each day the morning papers were scanned for news from the palace as to the Queen's condition. Those of May tenth gave no indication that the longexpected event was to occur that day, and not a few diplomats of the early-rising class started off for walks or drives in the parks and in the country. Although they all arrived for the ceremony, in more than one case messengers from their Legations and Embassies had to be sent for them, and there was rushing and running.

At ten o'clock that morning it became evident to the physicians at the palace that the birth would soon occur. Halberdiers were sent to summon the diplomats and others who were to be present at the presentation. The day happened to be 
the birthday anniversary of the Infante Don Fernando, husband of the Infanta Maria Theresa, who then lived at the Royal Palace. Desiring to show respect to this member of the royal family, I had left the American Legation at ten o'clock to go to the palace to express my congratulations by writing in the Infante's book. It was a beautiful spring day, and I decided to walk, and so sauntered along leisurely. The message summoning me to the palace because of the approaching birth of a child to the Queen reached the Legation about ten minutes after I had left. The halberdier sent from the palace to the Legation took a different route from what I did. The consequence was that sometime after eleven o'clock I arrived at the palace to present my felicitations to the Infante Fernando, only to see a great number of carriages of diplomats and Spanish officials in front of the palace door, and signs of unwonted activity. I divined that the Queen's accouchement had begun, and being told that such was the case, I took the first cab I could get and drove home at all speed, managed to dress and to get into my own carriage and drive back to the palace, arriving there at five minutes past twelve, about a half-hour before the birth. Some of my colleagues who had also just received the notice arrived at the same time.

The scene in the antecamara where we were gathered was an interesting one. In all about one hundred and fifty persons were present. Five or six of them were ladies of the Queen; the rest were the prelates, soldiers, statesmen, diplomats, and 
court officials mentioned in the decree. All were in full uniform with decorations, except myself and five or six others, who were representatives of civil organizations, like the deputies in Congress. We wore full evening dress. The salon in which we were assembled was the antecamara, very near the Queen's room. All were in a state of expectancy. The birth occurred at half past twelve, at which time the President of the Council of Ministers, who had been in a room adjoining that of the Queen, opened the door leading into the antecamara and in tones of rejoicing cried out: "Gentlemen, Her Majesty the Queen has just given birth with all felicity to a male child, the Prince of Asturias, heir to the Crown. Long live the King! Long live the Queen! Long live the Prince of Asturias!" Each viva proposed by him was answered with a loud chorus of vivas. Everyone was in a state of joy, not only because the Queen had been so happily delivered, but also because it was a boy. The Spaniards were naturally the most enthusiastic. Veteran generals, former ambassadors, Ministers of the Crown, were actually hugging each other with delight. Servants were running through the corridors shouting: "Es niño!" ("It is a boy!") Outside the palace thousands - perhaps more than ten thousand people - had assembled, and as from the Punta del Diamante the national flag (signal that the newborn was a boy) was hoisted, vivas broke out and excitement became contagious, the garrisons at the same time beginning their salute of twentyone guns. 
About fifteen minutes after the birth had taken place the door into the antecamara was swung open by the Lord Chamberlain and the King appeared, smiling and carrying the newborn Prince of Asturias in a shallow basket, shaped like a large deep silver platter, lined with soft cotton. Over the naked infant was thrown a piece of rare old lace, long used for this purpose at such ceremonies. The Minister of Grace and Justice lifted it, so that upon his own authority he could make, as Chief Notary of the Realm, the certificate that it was a boy and not a girl. Those who were invited to the ceremony so nearly filled the room that it was quite impossible to form a circle, and the result was that the assemblage practically separated into two halves, leaving just space enough for the King to pass with the newborn baby, followed by the Infanta Eulalia and the Duquesa San Carlos, the Grand Mistress of the Robes, the chief of the ladies of the Queen. The King walked slowly, still carrying the baby in the basket. He made an instant's halt several times. Those who, like myself, were, near the front of the group were fortunate enough to see the baby Prince perfectly. He was beyond question an unusually strong and healthy-appearing infant. To the surprise of all he moved and turned in the basket in which he was carried. His eyes were open, and he had an abundance of fair hair. To the congratulations which I had a chance to offer the King, His Majesty, with evident pride, replied, as he did to many others, "And he weighs more than four kilos" (nearly nine pounds). The King carried the 
infant nearly two-thirds of the way across the room, when the Infanta Eulalia and the Duquesa San Carlos protested against keeping the baby any longer in a room "where he would surely catch his death cold." The King then turned and carried the infant out of the room and back to its mother amidst renewed cries of "Viva el Rey!" "Viva la Reina!" "Viva el Principe de Asturias!" The act of presentation was at an end. It was so informal that it could hardly be called a ceremony.

Throughout Spain rejoicing was general. Madrid was en fête. The three days following the Prince's birthday were proclaimed holidays. During that time flags flew from all the public buildings and from the foreign Embassies and Legations. Decorations and illuminations abounded everywhere. Pardons were granted by the King to a number of persons under sentence of death. Orders and decorations in goodly profusion were bestowed by the King. The Queen's physician was made a Marquis. The lady in waiting on duty that day was created a Duchess. His Majesty gave about forty thousand pesetas as alms to be divided among a number of charitable institutions, and some of the municipalities followed his example. Soldiers, policemen, palace functionaries, and palace servants were all in gala dress. Thousands of people went to the palace to inscribe their names in the albums of congratulations. I was directed, as American Minister, to express to the King the President's felicitations and to the Ministry of State those of the Secretary 


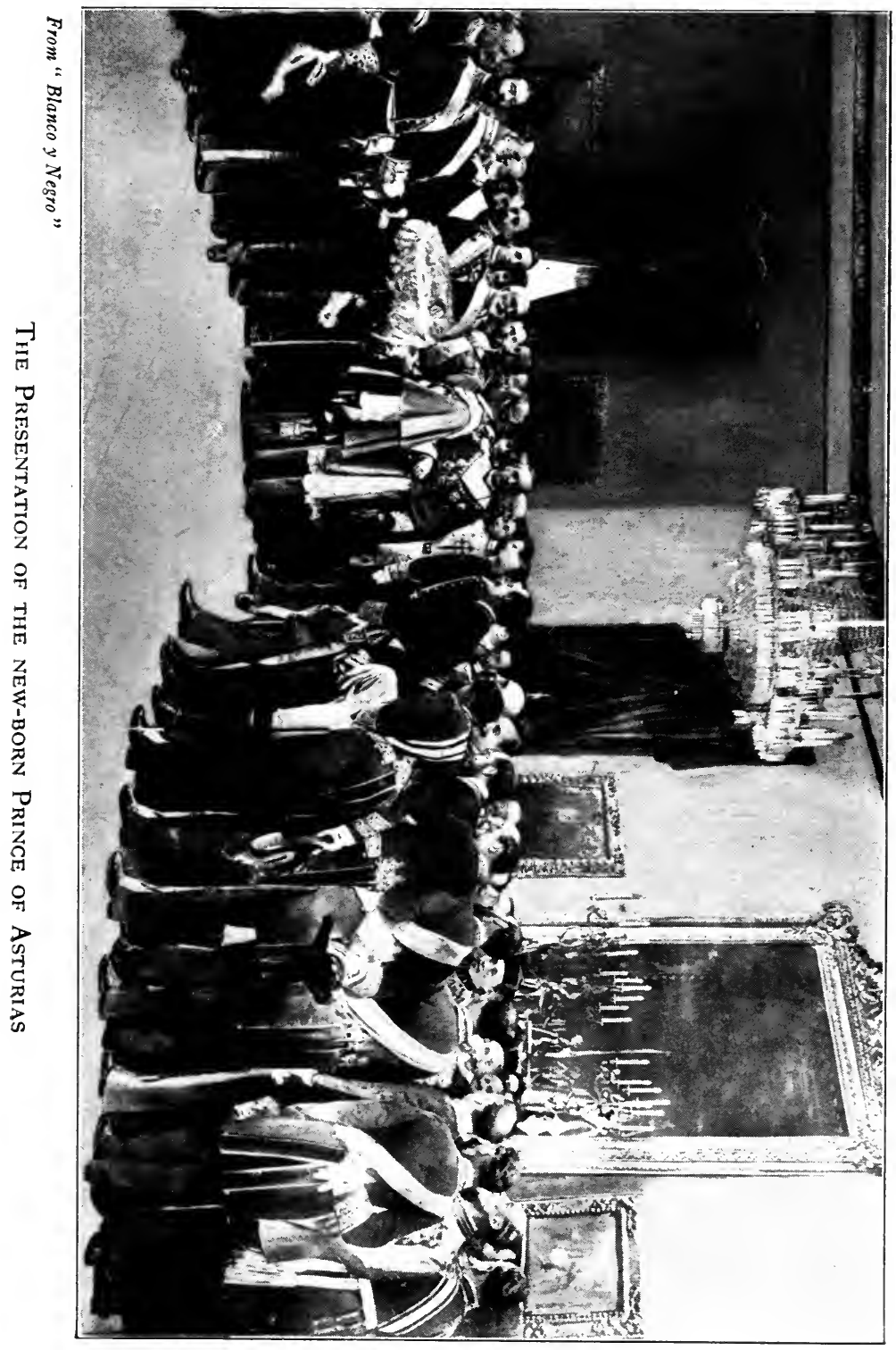




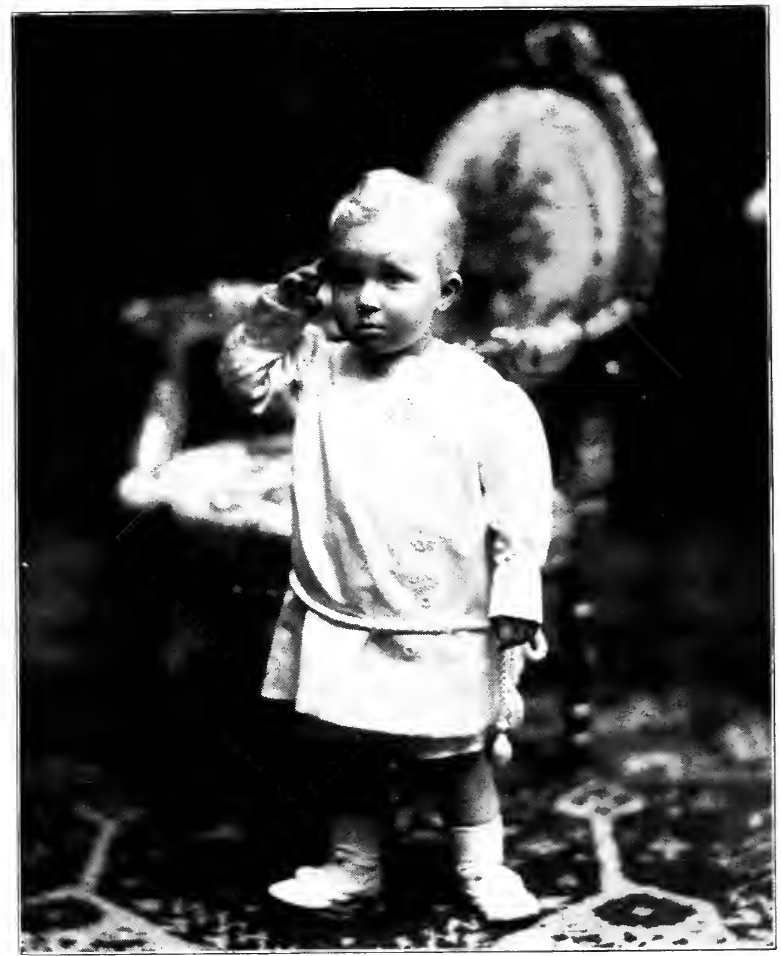

Photo by Kaulak

The Prince of Asturias when about One Year Old

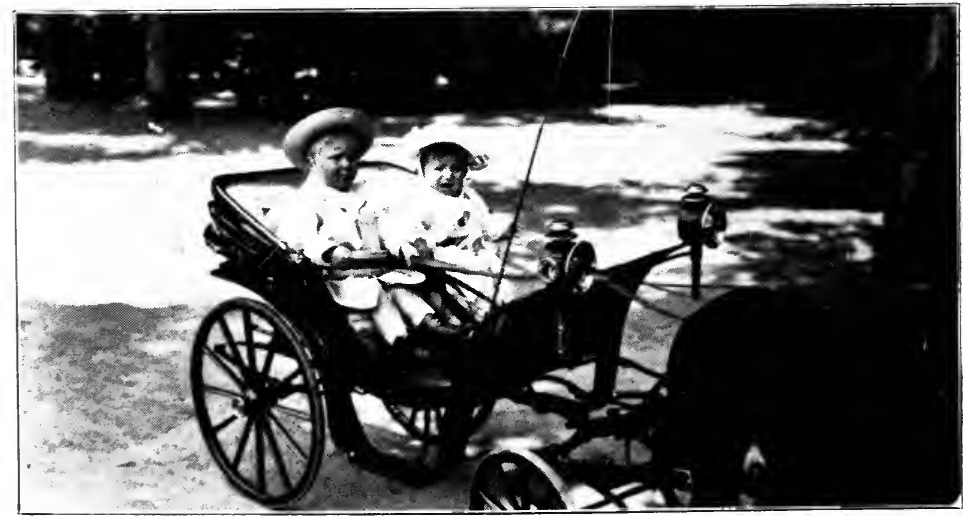

The Prince of Asturias Taking His Brother Don Jaime Out FOR A RIDE 
of State and of the American Government, and I also transmitted the messages of congratulations that were sent on by Mr. Whitridge, who had been Special Ambassador at the King's wedding, and by General Draper, former American Ambassador to Italy, who had only a short time previously visited Madrid and been presented to the King, and who had predicted that the royal infant would be born on the tenth of May, and who was quite delighted at the literal fulfilment of his prophecy.

The act of inscribing the name and date of birth of the newborn Prince in the Civil Register of the palace occurred two days after his birth, before the Minister of Grace and Justice as Chief Notary of the Realm, and in the presence of only four or five members of the royal family. This was several days before the sacrament of baptism was administered. The names of the new Prince, as entered in the Register and as afterwards conferred in baptism, were Alfonso Pio Cristino Eduardo Francisco Guillermo Carlos Enrique Eugenio Fernando Antonino Venancio. What is in a name? Why was this array of names given to this small Prince? Alfonso, in honor of his father; Pio, for the Pope, who was to be his godfather by proxy; Cristino, in honor of his paternal grandmother, Maria Christina; Eduardo, Francisco, Guillermo, and Carlos, in honor of King Edward of England, Francis Joseph of Austria, Kaiser William of Germany, and King Carlos of Portugal, the four sovereigns who through princes of their respective houses were to be witnesses at the baptism which was to take place a few days later; 
Enrique, in memory of Prince Henry of Battenberg, father of the Queen; Eugenio, in honor of his mother, one of whose names was Eugenia; Fernando, to perpetuate a name borne by many of Spain's most illustrious kings, and Antonino and Venancio because they were two of the saints of the day upon which the Prince was born. These names, it should be remembered, are only the first or Christian name. Were we to write the name of the little Prince in full we should have to add Bourbon y Battenberg, the Spanish custom requiring the mother's family name to be put last, although the father's family name is regarded as the child's family name, and by that he is usually spoken of, although the full form is more strictly correct.

But to the world the little Prince will be known by the title "Prince of Asturias," which for centuries has been given to the heir to the throne. It is derived from that region in the north of Spain, on the coast of the Bay of Biscay, to which the early Christians were driven back by the Moors, and from whose mountain fastnesses they began, in the eighth century, the wars for the reconquest, which lasted more than seven hundred years, and which ended with the fall of the Alhambra and the capture of Granada in 1492 , and with the unification of Spain under Isabella the Catholic and Ferdinand.

Not many days after the birth of the Prince the ceremony of the rendering of homage to him by the Commission appointed by the authorities of the Principality of Asturias took place in one 
of the grand salons of the Royal Palace. In the name of those whom they represented the Commission declared fealty to the new Prince, and, in accordance with immemorial usage, delivered to him as a token of homage one thousand doblas (an old Spanish gold coin represented by twenty-five pesetas, equal to about five dollars), and presented to him, to be worn hanging from his neck, the Cross of Victory, the emblem under which Pelayo, the first of Spanish kings, began the wars against the Moors. The ceremony was brief and simple. The King, dressed in his uniform as a captain general, was seated in a chair of state. At his left was the little Prince in the arms of his official governess, and near him was Queen Maria Christina. The only other member of the royal family present was the Infanta Isabella, and she was there not because she was a princess, but because she herself had twice been Princess of Asturias, heiress to the throne, - once when her mother was Queen, before the birth of her brother Alfonso XII, and again after his accession and before the birth of his children. Behind these persons were the Ministers of the Crown and the high court functionaries, in full uniform, and the ladies of the Queen in court dress. Upon a table covered with a cloth of gold was an exquisitely fashioned silver casket containing the thousand doblas. Grandees of Spain were grouped at one end of the room, and the gentlemen in waiting, in court dress, and the officials of the halberdiers and of the Escolta Real, in uniform, took the places assigned to them. The Commission then entered the room, 
and after they had made reverence to the King, their president, Señor Alexander Pidal, one of Spain's most eminent men, delivered an address of great eloquence, drawing inspiration from the gallant history of the unconquered principality. As soon as he finished he handed to the King a salver upon which was the Cross of Victory, which His Majesty then hung around the neck of his baby son. The silver casket was thereupon opened and the thousand doblas were given. The King then made a speech of great expressiveness, and the ceremony ended.

Aside from its personal interest the birth of the Prince of Asturias was worthy of note for its political effect. Notwithstanding that females may inherit the crown of Spain in default of male heirs, it was universally felt that the birth of a son to Their Majesties gave greater stability to the dynasty and enabled it the better to maintain itself against Carlism, regionalism, and all other revolutionary movements. It was believed that the succession to the throne was better guaranteed when the heirship was fixed so that the succession could not be changed except by the death of the heir. Even many of those who are opposed to the dynasty, republicans in theory, were glad that the royal child was a prince, for they recalled the prolonged wars of the last century growing out of the dispute as to the right of women to rule, and they felt that the tranquillity of the country was less likely to be disturbed when the successor to the throne was a boy and not a girl. Moreover everyone who was to 


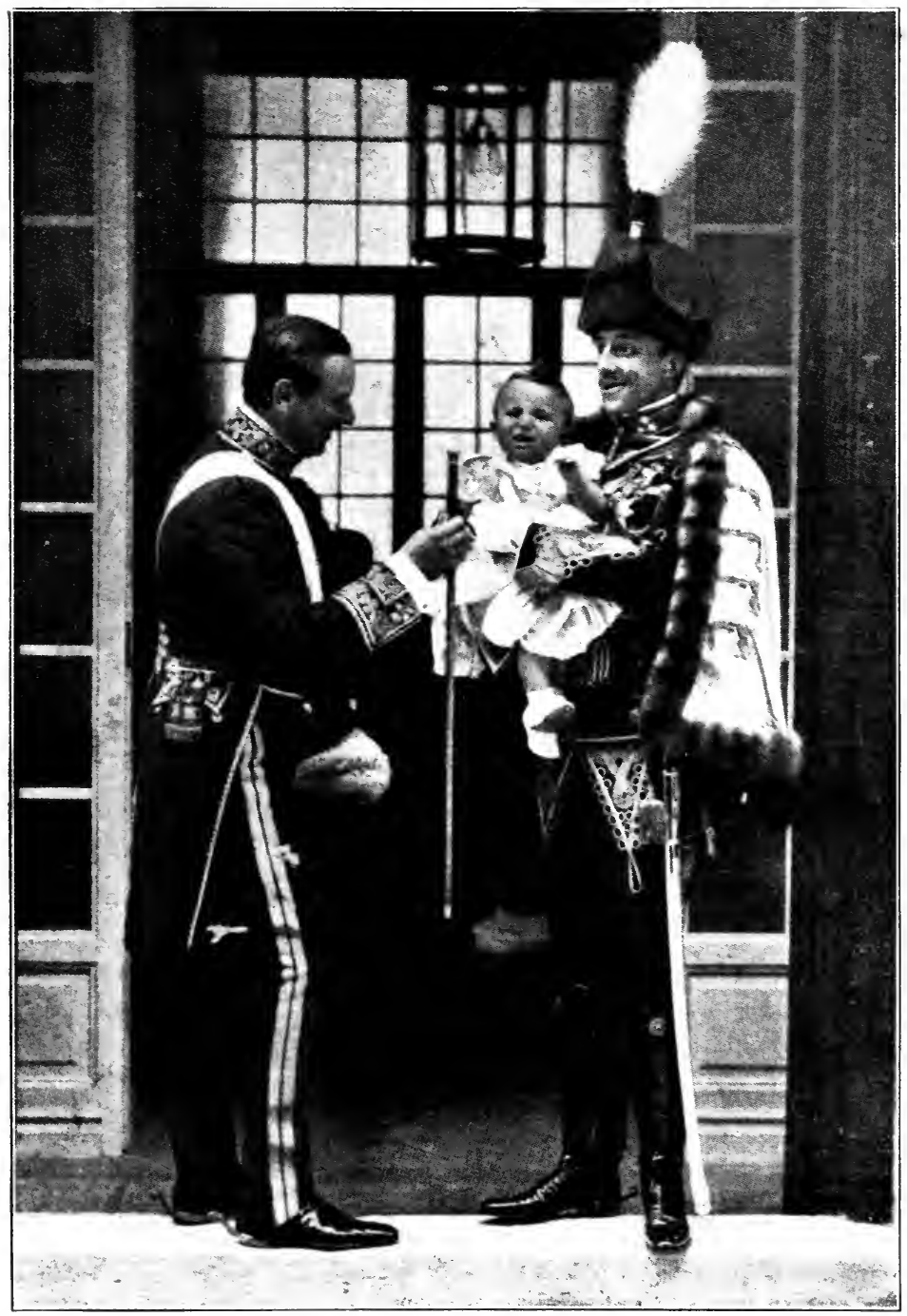

Pholo from "Nuevo Mundo"

The King in the Uniform of Colonel of Hussars in the Hungarian Army with Don Jaime in his Arms, Accompanied by the Marquis of Viana, Grand Master of the Horse 
live under the rule of that Prince when he should become King, whether at heart a monarchist or a republican, was very glad that he was a healthy child and promised to become a healthy man. Incidentally the birth of a son beyond question won for the Queen a place in the affections of the people and increased the King's personal popularity. The birth of the Prince was therefore an event of great importance in contemporaneous Spanish history, as well as the occasion of interesting and unique ceremonies.

Mr. Dooley, the American humorist, who writes of current events with Irish wit and in the Irish brogue, gave an interesting account of the birth of the Prince of Asturias and of the ceremony of the presentation. Perhaps the reader, recalling the crowded room in which the little naked baby was presented, will agree with the remark with which Mr. Dooley closes his vivid and characteristic description:

"And, Hennessy, when they carried the baby out of the room, someone shouted out 'Long live the Prince!' And, Hennessy, do you know what was the most wonderful thing of it all? Well, the most wonderful thing of it all was that the child lived!" Yet those who know that all Spanish royal babies, whether heirs to the throne or not, are thus presented, and above all, those who on this occasion observed the almost phenomenal physical strength of this baby, looking as if strong enough, like the infant Hercules, to strangle serpents in his cradle, saw no reason to wonder that he lived. But whether we wonder or not, 
242 THE COURT OF HIS CATHOLIC MAJESTY

all those who love Spain hope that the young Prince will so grow up and develop, in body and in character, that to the Spaniards' enthusiastic cries of "Viva el Principe de Asturias!" everyone may sincerely respond: "Viva!" 


\section{CHAPTER XIII}

The Baptism of a Prince and the Mass of Purification.

7 IGHT days after his birth the Prince of Asturias was baptized in the Royal Chapel with an elaborateness and stateliness of ceremony greater than that which had characterized any event since the wedding of his parents. The Supreme Pontiff, represented by a cardinal, and the former Queen Regent, in person, were his godparents. Sovereigns, represented by princes of the blood, were witnesses. The royal family down to its youngest members, who are rarely seen at court functions, were all there, save the Queen. An assemblage of high prelates such as has seldom, if ever, been seen outside of some great Church council, even in Catholic Spain, was present; while the concourse of nobles and soldiers and statesmen and diplomats of Spain and of foreign countries was unusually large. It would have been impossible for the Royal Chapel to hold another person. In fact so crowded was it that although only those of the very highest rank had been admitted, it was with difficulty that the royal retinue made its entry and its passage from the door to the baptismal font. 
Interest was not confined to the official class and to the court circle. People of all ranks and conditions were keenly excited, and beyond question, as a mass, were sincerely happy. Several thousand persons, no small proportion of them of the aristocratic class, were admitted to the galleries. Tens of thousands crowded and practically filled the great Plaza de Oriente, the square in front of the palace. They overflowed into the Plaza de Armas, the palace courtyard, pushed in between the lines of halberdiers, and took possession of the arched galleries running around the lower floor of the patio of the palace. Many of these came early to obtain vantage points from which to see the constantly arriving carriages of the invited guests. These were hundreds in number, and everyone's equipage was, if possible, more elegant than on other court days. Liveries were new and more showy than usual, and the harnesses trimmed with brass or nickel had been rubbed and polished until they fairly shone. The Nuncio, Cardinal Rinaldini, who was to represent the Pope as godfather, was escorted from the nunciature to the Royal Palace with all the honors due to the high position which he was that day to fill. He rode in a grand carriage de gala, and his escort was a detachment from the mounted Hussars of the Princess, a troop which, with the Escolta Real and the Hussars of Pavia, is the most handsomely uniformed in the Spanish army. To the crowds in the street, the spectacle of the coming of the invited guests was surely a fascinating one; for they remained until the last 
had arrived, and continued there until the ceremony was over, and even after that, until every guest had left the palace and driven home.

With more splendor than usual, even on fête days, the long upper galleries leading from the royal apartments to the Royal Chapel were decorated that day. The finest of the tapestries from the royal collection were hung on the walls; the floor was richly carpeted. Halberdiers, in their picturesque uniforms, stood in double line, shoulder to shoulder, forming a guard of honor and a veritable hedge, preventing access between them by anyone to the aisle through which the court was to pass. Back of the halberdiers stood, closely crowded, the thousands of privileged persons who were to see the pageant of the royal procession to the chapel, although it was impossible to give them permission to witness the ceremony in the chapel. By special order, on this day, even those who were admitted only to the galleries were to wear, if men, uniform or full dress; and if women, the white mantilla. There is no headdress more graceful than this; and the scene in the galleries on that beautiful day, with thousands of women in light summer costumes and with white mantillas on their heads, ranged beneath the tapestries of fine texture and noble composition and harmonious coloring, with men in handsome uniforms, and the halberdiers, in their quaint dress, standing in front, was a most interesting one. Between these lines of spectators passed all those who had been invited to witness the ceremony. The grandees and chamberlains and gentlemen in waiting went 
246 THE COURT OF HIS CATHOLIC MAJESTY

direct to the apartments where the procession was to be formed. Here, upon silver trays placed on three tables, were the sacred vessels and articles which seven grandees were to bear to the chapel to be used in the service.

We who were in the diplomatic tribune many minutes before the hour fixed for the baptism had good opportunity to survey the chapel and to note its decorations and special furnishings. The high altar was profusely adorned with white flowers, roses, and carnations. In the centre of the chapel was the baptismal font of Saint Dominic (Santo Domingo de Guzman), founder of the Order of Dominicans, the "preaching brothers," who have played so tremendous a part in the history of the Church in Spain. At that very font Saint Dominic, born in 1170 , was baptized, and for centuries it has always been used at the baptism of princes of the royal house. Originally it was a basin of reddish marble resting on a cylindrical base of solid mahogany. A little over a hundred years ago Charles IV caused it to be completely covered with silver. Near it were tables covered with tapestries upon which the grandees would place the seven articles that they would bear for use in the baptism, and a little farther away was another table upon which were laid the magnificent vestments of the Cardinal Archbishop and the four bishops who were to assist in the service. These were the most costly in use, the rich cloth of which they were made being fairly buried under embroidery of gold and silk thread and laden with precious stones. Some 
distance away was the cortina, or throne, which the King was to occupy. In the choir and chancel were to be seen forty-one archbishops and bishops, all splendid in their robes.

The diplomatic tribune was packed. The ladies were all in court dress with mantilla - all except the wife of the chargé d'affaires of China, who appeared in her national dress of rich silks handsomely embroidered. Seats were provided for the ladies and for the ambassadors and most of the Ministers; but so crowded was the tribune that the secretaries and attachés had to stand, and even standing room was at a premium. Conspicuous in the group of brilliantly uniformed men were the members of the Turkish Legation with their red fezzes and the members of the Chinese Legation with their black hats, which of course they wore throughout the service. In the other tribunes were all the array of statesmen and generals and court officials who had been present at the birth and presentation of the Prince of Asturias.

The booming of cannon announced the starting of the procession from the royal apartments. Slowly it passed along the galleries. First came two ushers, followed by the Gentlemen of the House; then two mace-bearers and a double file of chamberlains. Next the four kings-at-arms, dressed in their dalmatics, and the grandees of Spain, covered. Then came seven gentlemen in waiting, also grandees of Spain, bearing on silver trays the salt, the cape, the candle, the ewer, the towel, the cotton, and the marchpane which 
248 THE COURT OF HIS CATHOLIC MAJESTY

were to be used in the baptismal rite. The princes of the Church, the three Spanish cardinals, who were at that time the archbishops of Toledo, Santiago, and Burgos, followed, all dressed in their red robes. Behind them came the Spanish royal princes, the Infantes Don Alfonso of Orleans and Don Carlos, the latter leading by the hand his little son Alfonso, who up to eight days previous had been the heir-presumptive to the throne. Dressed in a white sailor-suit, gravely saluting the people as he passed, this small boy was the object of great interest and, in a sense, of sympathy. How many there were in that gathering who recalled how nearly he came to becoming King, a year before, when the attempt was made upon the life of the King! This day he was here in the chapel to do honor to the baby cousin who had displaced him.

But the interest of all was, of course, far more keen in him who came next in this procession, the Prince of Asturias himself, borne in the arms of his official governess, the Countess of Llanos. His face could hardly be seen, so covered was he with lace and embroidery. He was sound asleep, and was not awakened even by the loud music of the Halberdiers' Band, which followed in the procession. On either side walked the godparents. The Nuncio, Cardinal Rinaldini, wore over his red robes the blue band of the Grand Cross of Carlos III, and Maria Christina, handsomely gowned, wore many orders and decorations. Immediately behind the royal infant came the foreign princes. The Archduke Eugene of Austria, 
brother of Maria Christina, was a commanding figure. His great height, six feet six inches, was accentuated by the high zibeline cap which he wore. Prince Arthur of Connaught, cousin of Queen Victoria, was conspicuous in the uniform of the Scots Guards with an enormously high busby, the fur of which came down so that it almost covered his eyes. The Duke of Oporto, brother of King Carlos of Portugal, and Prince Frederick William of Hohenzollern, cousin of the German Emperor, were the other two representatives of sovereigns.

Next came the proud father, King Alfonso, wearing a captain general's uniform. The Golden Fleece hung about his neck. He also wore the . collar of the Order of Carlos III and the Grand Cross of Isabella the Catholic. On his shoulders were the white bows of the English Order of the Garter. The Infanta Isabella followed, leading by the hand her grandniece, the Infantita Isabella, the little daughter of Don Carlos, not then three years old. Princess Beatrice, mother of the Queen, and the Infanta Eulalia then came, walking side by side. All the royal women wore court dresses with long trains, splendid jewels, and many orders and decorations. The Infanta Maria Theresa and her husband, Don Fernando, had been prevented from attending the presentation of the Prince at the time of his birth because they were quarantined in another part of the palace on account of measles. They witnessed the baptism from a glass-enclosed tribune at one end of the chapel. Next in the procession were the three 
young princes of Bourbon-Naples, brothers of Don Carlos. Then followed the long retinue composed, as usual, of the "high service," the Palace Chiefs, and the gentlemen in waiting of the royal house and of the houses of the Queen Mother and of the Infantas, as well as the ladies in waiting of the latter. The ladies of the Queen, twentythree in number, had already taken seats in the tribune assigned to them in the chapel. They did not form part of the retinue, because the Queen did not attend the ceremony. The suites of the foreign princes, who came next, were composed of tall, dashing, soldierly men. The officers of the Escolta Real, the halberdiers, and the famous band of the latter brought up the rear of this quite imposing parade.

Entering the chapel, everyone found his designated place. The mace-bearers stood on each side of the door. The four kings-at-arms, in their mediæval garb, stationed themselves at the four corners of the platform upon which the baptismal font had been placed. Around it were grouped the infant Prince who was to be baptized and the members of the royal family and the foreign princes who were there as witnesses. Back of them were ranged the Palace Chiefs and the ladies in waiting; still farther back were the grandees and the suites of the royal visitors. The gentlemen in waiting, who bore the seven articles to be used in the service, placed them on the table. From the other table were taken the magnificent vestments, which were then put on the Archbishop and his assistants. The Queen 


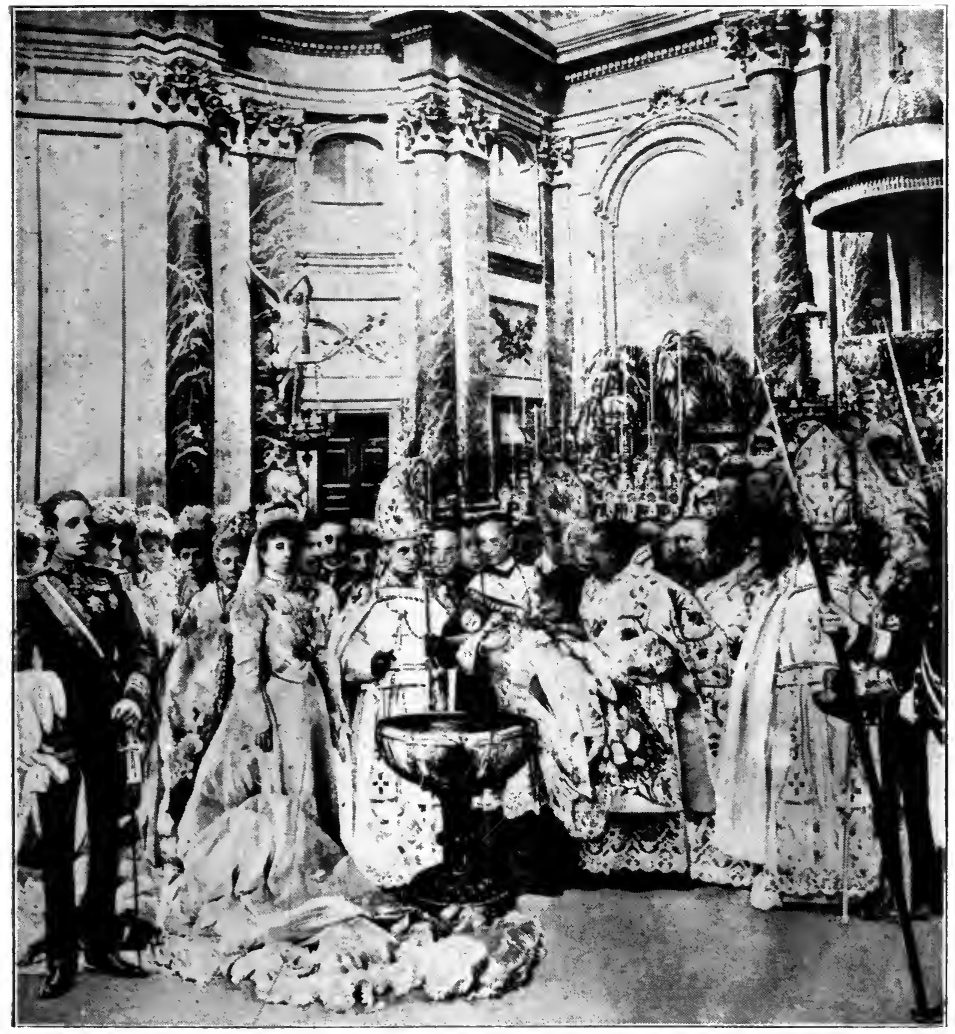

From "Blanco y Negro"

The Baptism of the Prince of Asturias 


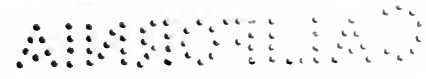


Mother took the Prince of Asturias in her arms and advanced toward the font, as also did Cardinal Rinaldini. The baptismal service of the Catholic Church, as used for all its members, high or low, prince or peasant, was employed, without additions or alterations or omissions. Water for the baptism had been brought from the River Jordan. It was poured out from a golden shell, and as it touched his head, the baby Prince gave a feeble cry, and the King, who was seated on his throne some distance away, smiled. The names now given to the Prince by the Church were the same as those that had already been entered in the Civil Register. The service was very brief. Throughout it selections from Mozart were played by the orchestra.

At the conclusion of the baptismal service, other ceremonies took place, which were very curious, considering the extreme infancy of the Prince. The Cardinal Archbishop had hardly divested himself of his robes, and the godparents of the infant had hardly taken their seats, before the ceremony of making this eight-day-old baby a Knight of the Most Illustrious Order of the Golden Fleece began. The Chancellor and the Greffier of the Order approached the Prince, and turning toward the King, said:

"Señor, the Ministers of the Illustrious Order of the Golden Fleece have the honor to present themselves before you to witness the investiture as a Knight of this order of the august Prince whom Providence has granted to us for the greater splendor of the throne and the happiness 
of the nation, and who by the decree which.Your Majesty, sovereign head of the order, has made, must receive it from the hands of Your Majesty."

The royal consent being given, the treasurer of the order advanced and presented to the King, upon a golden salver, the insignia of the order. The King took these and, passing over to where the Prince was in the arms of Queen Maria Christina, he hung about his neck a tiny collar of this famous order, with the tiniest of golden sheep or golden fleeces pendant from it. It was the same collar which had been put on his grandfather, Alfonso XII, when as a baby he too was made a Knight of this illustrious order. The chancellor of the order then addressed the King again, saying:

"Señor, as Chancellor of the Illustrious Order of the Golden Fleece, I must make known to Your Majesty that, as the oath which the Knights of the order must take upon receiving investiture cannot now be taken by the Prince of Asturias, he remains obligated to take it when by the mercy of God he may arrive at an age competent to do so."

Then with a loud voice the Greffier announced: "Now is decorated with the Illustrious Order of the Golden Fleece, His Royal Highness, the Most Serene Señor Prince of Asturias."

Thus ended that ceremony. But still other ceremonies were to follow. Forthwith the venerable Cardinal Archbishop of Toledo, as Grand Chancellor of the Royal and Distinguished Order of Carlos III, and also of the Royal Order of Isabella the Catholic, with the secretaries and 


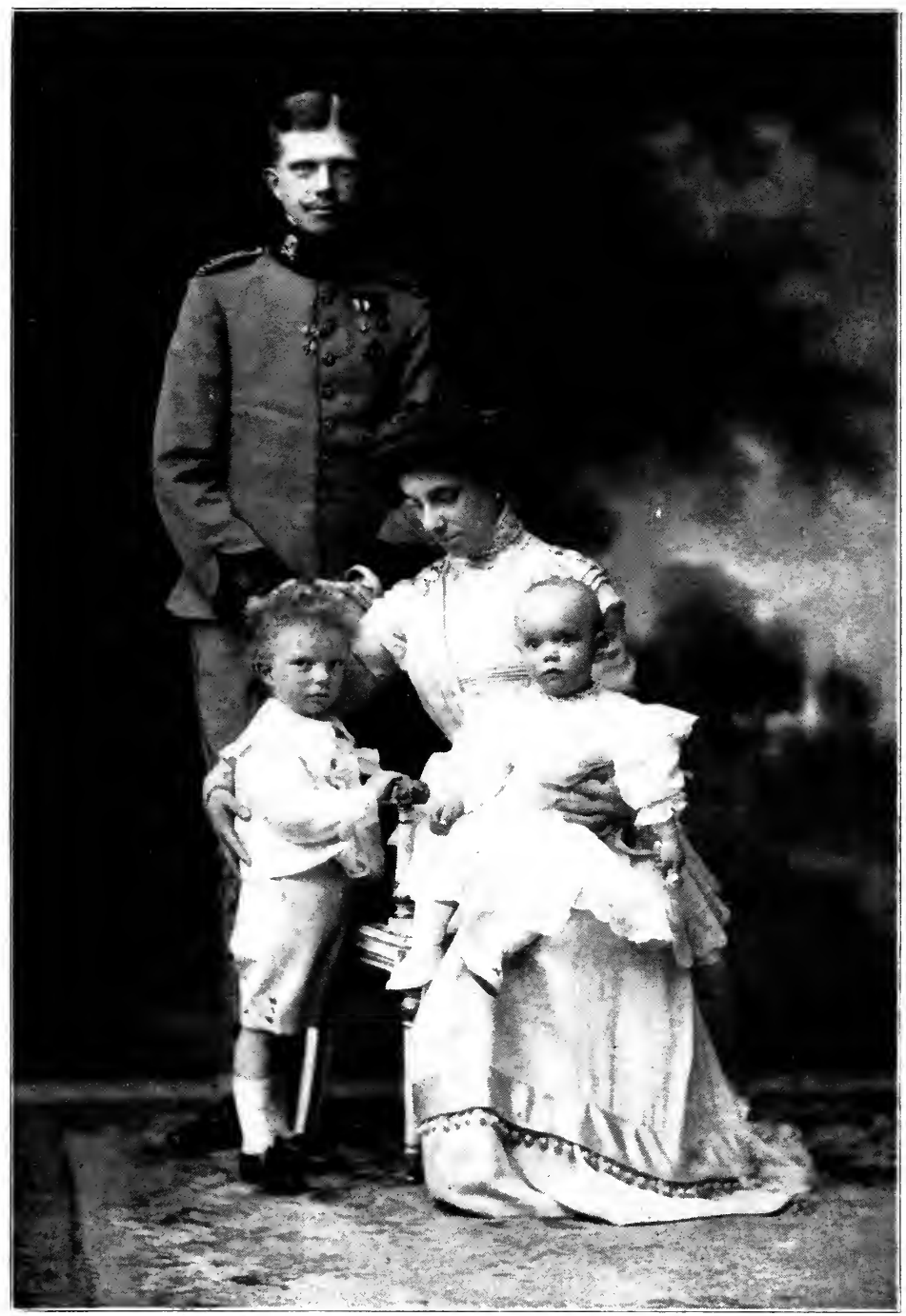

Fhoto by Franzen

The Infantes Maria Theresa and Fernando with Their Two Oldest Children (1910) 


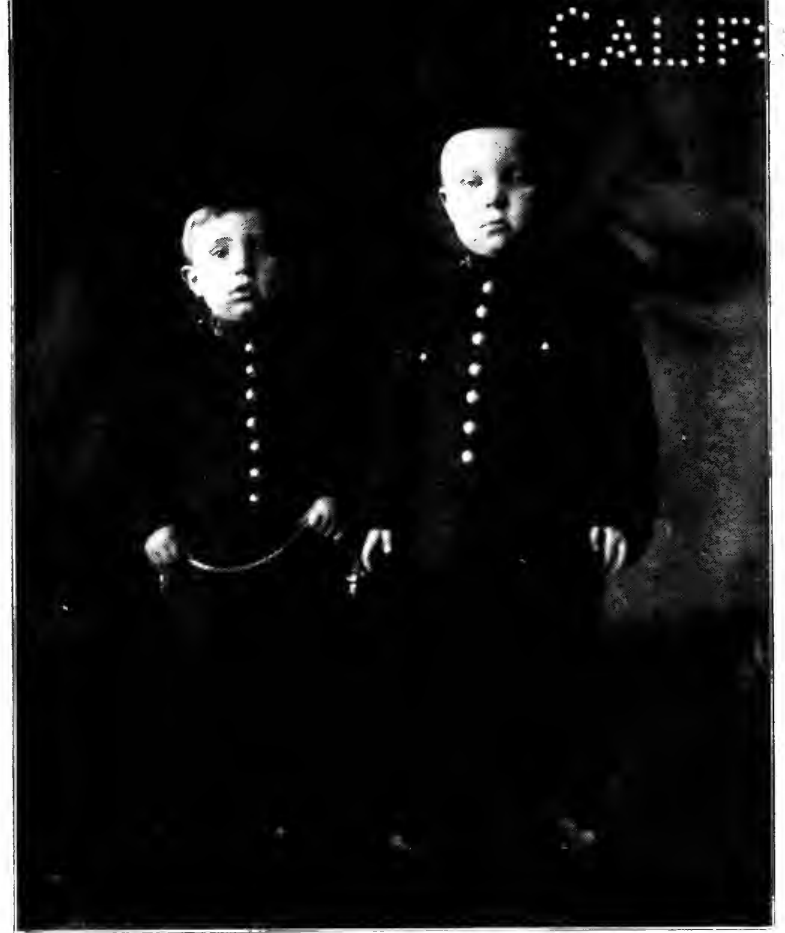

Photo by Kaulak

The Youngest Recruits in the Ariy, Don Jaime and the Privee of Asturias. When One Year Old They were Enrolled in the Army and given tile Uniforis of Privates of Their Respective RegineNts

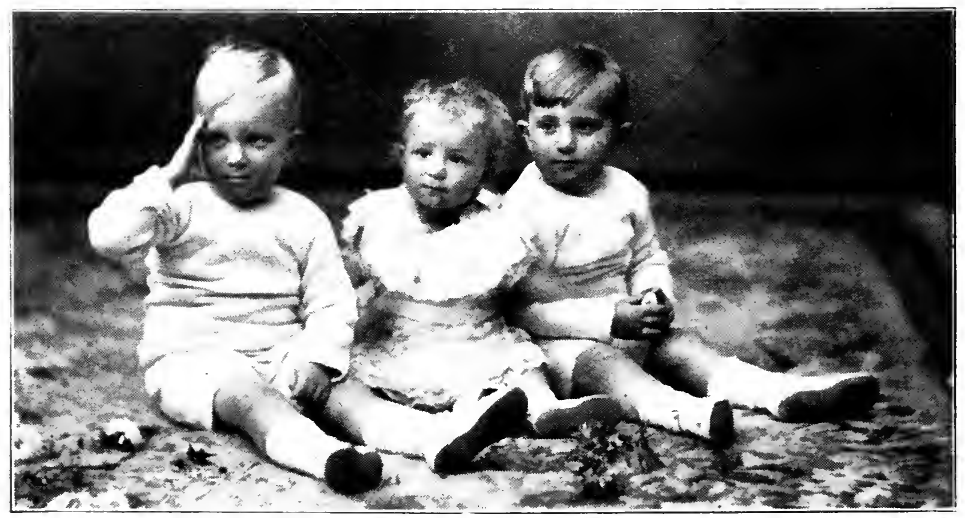

Photo by Franzen

The Royal Children in igio. The Prince of Asturias, Infantita Beatrice, Infantito Don Jaime 
treasurers and masters of ceremonies and controllers of these orders, advanced and, addressing the King, said:

"Señor, the Royal Orders of Carlos III and of Isabella the Catholic present to Your Majesty their respective insignia destined for His Royal Highness the Most Serene Señor Prince of Asturias, fulfilling thus with the greatest satisfaction and jubilation that which has been ordered by you, their sovereign and grand master."

The King then put the blue and white ribbon of Carlos III and the yellow and white of Isabella the Catholic on the little Prince, and then after a few minutes he removed them and handed them over to the treasurer of the order as custodian. With this the services and ceremonies of all kinds were at an end.

The royal procession was formed anew. In the same order and in the same state the King and the royal personages and the visiting princes, with their retinue and suite, and this time with all the ladies of the Queen accompanying them, passed back to the royal apartments through the long galleries still crowded with interested spectators.

About two years later I attended the baptismal service of the Infante José, second son of the Infanta Maria Theresa and the Infante Don Fernando. There were fewer high prelates and less ceremony than when the Prince of Asturias was baptized, but there were more babies. For there, in the arms of their stout and buxom Galician and Asturian nurses, were the King's two 
254 THE COURT OF HIS CATHOLIC MAJESTY sons, the Prince of Asturias and the Infante Jaime, born in 1908, and also the Infante Luis, the first-born son of Maria Theresa and Don Fernando. If there was, perhaps, less of magnificent and costly pontifical vestment than when the heir to the throne was baptized, there was something to replace it, - the wonderful peasant costumes of the nurses. These were so striking in pattern and color that they attracted the attention of everyone, although in general design they were similar to those of the nurses of many of the wealthy families of the capital. Yet so important are the dresses of the nurses considered, that minute descriptions of those worn on various occasions are preserved in the Ministry of State and in the Lord Chamberlain's office, so that they may serve as models and patterns for future generations of nurses. That worn by the nurse of the present King, when he was baptized, is thus described in one of the publications of the Ministry of State: "A dress of scarlet velvet with broad gold braid and a black bodice, a collar of large coral, long golden ear-rings, composed of many goldpieces of twenty-five pesetas linked together, and on the head an enormous bow of red silk, with gold border."

The Feast of the Purification of the Virgin, February 2, is regularly celebrated each year by the Spanish royal family in the chapel. In like manner, in imitation of the Virgin's presentation of the Holy Child in the Temple, the devout women of the Catholic Church, after their recovery from childbirth, appear in church to attend the services prescribed by the ritual. In the case of 
the queens and infantas it is a most elaborate ceremony.

Annually, when the Feast of the Purification is to be celebrated, the court in great state goes from the royal apartments to the chapel, passing through the galleries in the same manner as on the days of capillas publicas and of such ceremonies as the baptism of princes or the marriages of infantas. In the course of the service, great lighted candles are given to all those present, and, holding them in their hands, the King, the Queen, the Infantes, the Infantas, and the entire retinue of the court come out of the chapel and, preceded by the bishops and the other clergy, make a complete circuit of the galleries, chanting the song of Simeon as recorded in the gospel of St. Luke, chapter ii, verses 22 to 35 , wherein the infant Christ was declared to be "A light to lighten the Gentiles."

Following ancient custom as soon as the Queen or a royal princess who has given birth to a child has recovered sufficiently, she, like Mary of old, attends a service or mass of purification, and then the young child is presented in the temple or church. Afterwards a grand Te Deum is sung. This was formerly done in the church of the Virgin of the Atocha. But the rebuilding of this church has caused a suspension of the service in that place, and the ceremony for the Prince of Asturias was less stately than in former years. How imposing it sometimes was may be inferred from what occurred when the present King, Alfonso XIII, was presented in the church by his mother, Maria 
256 THE COURT OF HIS CATHOLIC MAJESTY

Christina. A few weeks after his birth the mass of purification was observed on Sunday, June 27, and was followed by a service the next day at the church of Atocha, when the Queen Mother and the baby King went to the church accompanied by a cortège more imposing than has ever since been seen in this land of pageant except the royal cortège which passed through the streets of Madrid on his wedding day almost twenty years later.

Records show that in that wonderful procession that went to Atocha's church for this presentation in 1886 , there figured mounted cavalry and equerries and palafreneros, and more than twenty unmounted horses, in ancient and oriental trappings, led by grooms of the royal stables, mace-bearers, trumpeters, life-guards, kings-at-arms, nine grandees of Spain in their ancient family state carriages, ten royal state carriages each drawn by six horses, - among them the tortoise-shell carriage, the bronze landau, and the carriage of the gold panels, - the famous mahogany coach, drawn by eight horses, going empty as a coach of respect, and then the "coach of the royal crown" drawn by eight horses. In the last were Maria Christina, dressed in full mourning, the baby King, then just seven weeks old, and his nurse in her wonderful and gorgeous dress of many colors. In the other carriages were the Infantes and Infantas and the visiting princes of the Houses of Bourbon, Orleans, and Habsburg, the Palace Chiefs, the ladies of the Queen and the lords and gentlemen in waiting. The captain general and the royal equerries rode beside the "coach of the royal crown," and 
the Escolta Real; on their splendid chargers, brought up the rear. At the church door the Cardinal, in full pontifical robes and surrounded by all the clergy, met the royal party. In the audience were the Diplomatic Corps and all the official world. A Salve and a Te Deum were sung, being interpreted in a masterly manner by the chapel choir and the royal bands and orchestra. On leaving the palace, on entering the church, on leaving it, and again on reëntering the palace, twenty-one guns were fired by a battery. Committees of the Senate, the House of Deputies, the Provincial Deputation, and the City Council went to the service in their grand gala coaches, with servants in full livery and with mace-bearers.

With such ceremonies and pageants are the kings and princes of Catholic Spain consecrated to the service of the Church and the State and to the defence of the faith of their fathers. 


\section{CHAPTER XIV}

\section{Gifts from the Pope: The Golden Rose}

and the Fajas Benditas

ACH year, on the fourth Sunday of Lent,
the Pope, in one of the chapels of St.
Peter's at Rome, in the presence of all the cardinals, with solemn ceremony blesses a golden rose. In very ancient times this treasure was then sent as a present to some great cathedral, or to a sanctuary of renown, or to an illustrious city. Later it was the practice to bestow it upon the Prefect of Rome, but for nearly a thousand years it has been the custom of the popes, from time to time, to present it, as a mark of great consideration and love, to some foreign king or queen of the Catholic faith, or to some mighty captain or other eminent personage who has warred or worked'for the interests of the Church. Historians disagree as to the exact date of the first gift of the golden rose to a person living outside of the Eternal City. Some assert that it was as early as the year 1046. All agree, however, that it was not later than 1096, in which year it is a matter of historical record that Pope Urban II bestowed it upon Fulcon, Count of Angers. In II 48 Alfonso VII of Castile was the first of a long list of Spanish sovereigns and princes to receive it. 


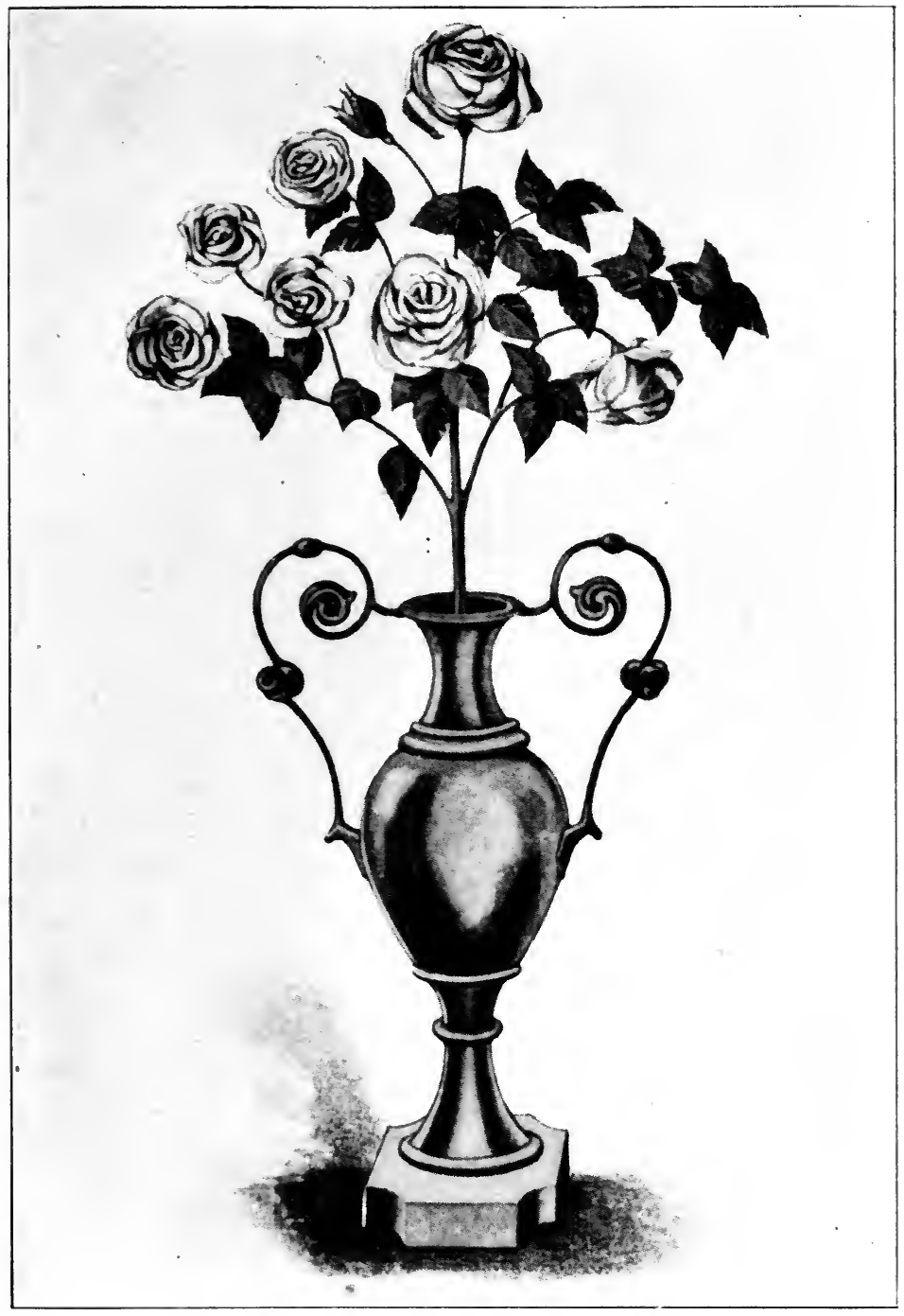

The Golden Rose 
Originally this jewel or piece of jewelry consisted of a single rose of gold, enamelled in red or set with a ruby, but several hundred years ago Pope Sixtus IV, the builder of the Sistine Chapel, ordered that it should be a cluster of roses of gold with gold leaves and thorns, all set with precious stones, the central rose to be larger than the others and so fashioned that in it, when blessed, might be deposited and preserved a small quantity of balsam and musk. He also ordered that it should be placed in a silver vase which should be gilded and which should bear the pontifical arms. Since that time it has always been made in this form. Exquisite as a specimen of the goldsmith's skill and of great intrinsic value, it is, however, for all those who receive it, still richer in symbolism. Its shape, its material, its attributes, - even its leaves and its thorns, its color, its perfumes, and its setting, - all speak to them the doctrines of the Church and the principles of the faith. And thus this gift, bestowed, by him whom they regard as the Vicar of Jesus Christ on earth, only upon kings and the mightiest of their subjects, is considered alike by Pontiff and by prince as one of the highest distinctions that can be conferred. The esteem in which it has been held has not been impaired by indiscriminate giving; the value of the honor has not been lessened by a too frequent bestowal of it. The golden rose, though blessed annually by the Pope, is not necessarily given away each year. Some special merit must exist or some exceptional service must have been rendered, otherwise the rose of one year is kept at St. Peter's 
to be blessed anew each succeeding year until the Sovereign Pontiff decides that some person is worthy to receive it. Various kings and queens of Spain have been recipients of it. Among them were the great Isabella the Catholic and her illustrious grandson Charles, when he, who was afterwards to become the great Emperor Charles the Fifth, was but a boy fifteen years old. To the wives of many of the kings it was given when they were married. It was given to Queen Isabella II in I868, the very year of her expulsion from her realm. Maria Christina received it in July, $\mathbf{1 8 8 6 ,}$ less than two months after the birth of her son, the present King, and the Pope more recently has bestowed it upon the present Queen. When Queen Isabella II received it, in 1868 , it had not been sent to any Spanish sovereign in nearly a hundred and fifty years, and, in fact, the rose presented to her had been blessed sixteen successive years before the Pope granted it to anyone.

There is, of course, almost always a Nuncio or other diplomatic representative of the Holy See at the court to which the golden rose is sent, but to deliver it through one permanently accredited would be to rob the act of its peculiar and special significance. Therefore an extraordinary mission is usually despatched from Rome, and an ablegate is commissioned as the bearer of the gift. Its acceptance is marked by great formality in all the courts of Europe, but in Spain it assumes the character of an elaborate ceremony regulated in all its details by rigid rules and ancient precedents, which are strictly followed. 
The ablegate, upon arriving in Madrid, is received in audience by the sovereign and presents the papal brief as his letters credential. A date is thereupon fixed for the ceremony of presentation of the golden rose. On the appointed day carriages and troops leave the Royal Palace for the nunciature, where the ablegate is lodged and where the golden rose has been temporarily deposited. A company of infantry has already been sent there to act as a guard of honor. Splendidly uniformed and mounted cavalry have also been sent to serve as an escort. The carriages, three in number, are full gala, such as are sent whenever a newly appointed ambassador goes to present his letters credential. An equerry of the King is detailed to ride at the side of the ablegate's carriage, and a gentleman in waiting, a chamberlain, and a grandee are sent to the nunciature to meet the ablegate, and, as the King's personal representatives, to accompany him in the carriage to the palace. A showy pageant they make as they pass slowly through the streets of Madrid on the way to the palace, the golden rose being conspicuously carried in the carriage with the ablegate and those who accompany him. Military honors are shown them as they enter the palace yard, and they are received with great formality and pass up the grand stairway lined by halberdiers who salute as they pass. On the landing they are met by chamberlains of the court and by four chaplains, who escort the golden rose to the Royal Chapel. Here are gathered all those of the court and Government circles and 
of the Diplomatic Corps who are the usual attendants at these and similar ceremonies. Everything has been previously arranged. To each person has been allotted his particular seat in accordance with the rules laid down in the protocol based upon the plans and diagrams, carefully preserved in the Ministry of State, showing the arrangements made for the same and similar ceremonies in years long gone by. Not only is the location of the seats or tribunes of each class determined accordingly, but their size and furnishing and even their upholstering differ according to the rank of the person or persons who are to occupy them and are regulated by these rules. For the princes and princesses, great gilded armchairs with hassocks and cushions and prayer benches are provided. There are narrow gilded chairs for some persons, settees with tapestry covers for others, benches with backs for certain classes, and benches without backs for others. All depends upon the class and category and rank of the individual.

The King and the royal family, with the retinue usual on state occasions and with the customary military guard, pass along the galleries crowded with the public and make a solemn entry into the chapel. Galleries and chapel are decorated and adorned, as is usual on these grand fête days. The Ministers of the Crown meet the King at the chapel door. Each person finds his designated place. At the left of the sovereign the ablegate sits in high state. On the other side of the chancel, facing the King and Queen, are the 
Cardinal Archbishop, the Patriarch of the Indies, the nuncio, the Bishop, and many other high prelates.

The mass is commenced; for the presentation of the golden rose is a part of a solemn religious service. The archbishop who has been specially commissioned by the Pope to celebrate it stops at a certain point in the service, and one of the chaplains of honor in a loud voice reads the papal brief which awards the golden rose to the Queen and which bestows the apostolic benediction upon the royal family.

Then the ablegate, standing before the Queen, delivers an eloquent oration. He eulogizes her high qualities and her meritorious services to the Church, which have prompted the Supreme Pontiff to bestow upon her this gift, whose symbolism and significance he sets forth in choice phrases of bold imagery. He closes with expressions of hope that the Pope's benediction may bring peace, prosperity, and glory to the royal house, and that all its members may reflect in their lives the virtues of their illustrious ancestors, the wisdom of the Alfonsos, and the piety of the Fernandos. Although the golden rose is brought from Rome by the ablegate, the actual delivery of it to the Queen is often entrusted to someone else. Frequently the archbishop who celebrates the mass is the one commissioned to deliver the rose. If so, when the ablegate finishes his speech, a chaplain of honor arises and reads another papal brief commissioning such person for this purpose and conceding plenary indul- 
264 THE COURT OF HIS CATHOLIC MAJESTY

gence. The Queen approaches the steps of the altar and kneels. The ablegate takes the golden rose from the altar and hands it to the archbishop, if he has been commissioned to deliver it. The latter, in turn, puts it into the hands of the Queen, repeating in Latin the formula prescribed by the ritual of the Church. The Queen rises and stands while the Te Deum is sung, and then returns to her seat. As soon as the mass is finished the sovereigns and the court return in state to the royal apartments. The Queen carries the golden rose, which, upon arriving at the camara, she gives to one of the chaplains, who places it in the oratory, where for the rest of the day it is exhibited to the public, who are allowed to approach and kiss it.

Thus ends the ceremony. But precedent and protocol and diplomatic usage impose other duties on the sovereigns and on the Minister of State. Both the King and the Queen must write letters to the Pope in their own hands, and supposedly of their own composition; and the King also writes to the Cardinal Secretary of State, as also does the Minister of State. The grandiloquence of these letters, specimens of which are publicly printed in the guides for Spanish diplomats, is such that those sent many years ago seem to be of sufficient interest to justify their translation and reproduction here.

Letter of His Majesty to the Cardinal Secretary of State on the occasion of the sending of the golden rose by His Holiness: 


\section{DON ALFONSO XII,}

By the Grace of God, Constitutional King of Spain.

To the Very Reverend Father in Christ,

Cardinal -

Our very Dear and Beloved Friend:

Monsignor - Apostolic Ablegate designated by Our Holy Father, the Pope — , to present to - the golden rose, has placed in Our hands the letter which for that purpose you have been pleased to address to Us in his favor. Your recommendation has strengthened more and more the esteem in which We were holding Monsignor —; and thus We have endeavored to Our utmost to show him honor, and this not only because of Our esteem for him, but also because of the fact that the Supreme Pontiff has chosen him for this delicate task.

We ask God All-Powerful, Very Reverend Father in Christ, Cardinal —-, Our Very Dear and Beloved Friend, that He keep you in His Holy and constant care.

Given at the Palace of Madrit on the day of (Signed)

I the KInG.

Letter of the Minister of State to the Most Eminent, the Cardinal Secretary of State on the occasion of the sending of the golden rose by the Pope:

Most Eminent Señor,

Monsignor - Apostolic Ablegate chosen by His Holiness to present to Her Majesty the Queen, my August Sovereign, the golden rose, has fulfilled his delicate mission in so worthy a manner as one could but expect from a person of his eminent talents. Thus it is that nothing has been so pleasing to me as to be able to comply with the request in the letter of Your Eminence addressed to me in his favor. In everything depending upon me I have endeavored to show him distinction and to aid him in the discharge of his mission; 
and nothing is more incumbent on me now than to give this testimony in his praise. In having the satisfaction of replying to Your Eminence, I avail myself with pleasure of this opportunity to reiterate the assurances of the high esteem with which I am

\section{Your Eminence's}

Most Attentive and Faithful Servant

To the Most Eminent,

The Cardinal

Secretary of State of His Holiness, etc.

Not only do the popes from time to time testify to their affection for the queens of Spain by bestowing upon them the golden rose, but for nearly two hundred years it has been their custom to manifest their paternal interest in the first-born child of the King and Queen of Spain, for whom he frequently acts as godfather, by sending to him or her, very shortly after birth, the fajas benditas, girdles or bands for the infant's wardrobe, which have been duly blessed by him. For many centuries it was the practice of the popes to make a similar gift to the heir to the throne of France. The despatch of these articles from Rome is sometimes made the occasion of the sending of a special embassy, but more frequently the Nuncio is specially accredited for this purpose. In either case the presentation of these gifts of the Pope is attended with much ceremony. On the day fixed for it the Nuncio or ablegate is brought in a royal carriage from the nunciature in all the state that characterizes the bringing of ambassadors who come for the first time to present their letters credential. $\mathrm{He}$ has the customary military escort, and the usual guard of honor is 
placed around his palace and military honors are rendered to him when he arrives at the Royal Palace. In every respect he receives the honors of a sovereign or a sovereign's personal representative. The Introducer of Ambassadors and gentlemen in waiting descend to the first landing of the grand stairway and escort him to the throne room. There the King, the Ministers of the Crown, and the grandees have all assembled in full uniform, and the Queen and the ladies of the Queen in court dress. The etiquette of the ceremony is very strict. It declares that Their Majesties should stand, but if for any reason they sit down, then a settee must be brought in so that the Pope's representative may sit. If the King puts on his hat, and as a consequence the grandees of Spain, who have a right to cover themselves in his presence, put on their hats, then the Nuncio shall put on his biretta. The Introducer of Ambassadors announces the Nuncio. Three bows are made by the papal representative as he approaches the throne. He delivers an address and presents to His Majesty the papal brief, his credentials. The King makes a short response and descends from the throne.

Then with the Nuncio at the right of the King, Their Majesties, followed by all the court, lead the way through the long series of salons to the room of the baby Prince or Princess, where the girdles or bands have been previously placed by the auditor (first secretary) of the nunciature. The Nuncio then personally wraps and binds them about the body of the infant and 
268 THE COURT OF HIS CATHOLIC MAJESTY shows to the King and Queen other gifts which the Pope usually sends at the same time. Discourses are made and prayers pronounced. Taking leave of the King and Queen, the Nuncio goes to present to the various Infantas the letters which the Pope has addressed to them, and then in full state he is escorted back to his palace. Immediately thereafter he is required, in his capacity as a special representative of the Pope, to go and call upon the Prime Minister and the Minister of State, who, according to the protocol, "must return the call within a few minutes." 


\section{CHAPTER XV}

The Washing of the Feet and Other Religious Ceremonies

NE of the most interesting ceremonies of the Court of Spain takes place on Holy Thursday, when His Catholic Majesty, following a custom which has been, more or less continuously observed since its inauguration by Fernando III (el Santo) in 1242, washes the feet of thirteen poor men and immediately afterwards gives them a dinner at which he personally serves them. It is a solemn and reverential service of royal humility in imitation of the Great Master's act of washing the feet of the disciples; nevertheless it is marked by all the splendor and pomp of this ceremonious court. When the health of the Queen permits, she at the same time renders a like service to twelve poor women, and as she is accompanied by the ladies of the Queen, all in superb court dress, the spectacle is one of added brilliance. During the years of my residence in Madrid, the condition of the Queen each spring prevented her participating in the service except as a spectator.

The thirteen poor men (and the twelve poor women, if the Queen is to take part), with two substitutes, are chosen by lot from lists of the poor furnished by the proper authorities of cer- 
270 THE COURT OF HIS CATHOLIC MAJESTY tain parishes. Duly advised that they have been selected, they repair to the palace on Monday of Holy Week, and after being identified by the chaplain and the inspector general, they are carefully examined to see if they are free from disease. They are then turned over to a tailor, who formally contracts to present them at the palace on Holy Thursday, clean and dressed in new suits of clothing of a fixed traditional pattern and cut. On the appointed day they arrive two hours before the beginning of the ceremony, garbed as required. The court pharmacist, in order to make certain that they are clean, causes his assistants to wash the right leg of each one carefully from the knee to the toes and to perfume it, and also to perfume the clothing.

The Hall of the Columns is the scene of the ceremony. It is an immense room next to the guard room of the halberdiers at the head of the grand staircase. Ordinarily it is barren of furniture and of decoration, except for its magnificent columns, its ceiling paintings, its floor of variegated marble, its medallions, its trophies of arms, a few bronze and marble statues, and several rare inlaid tables; nevertheless it is impressive because of its size and the chasteness of its architecture and its majestic simplicity. But on the day of the washing of the feet it is superbly furnished. The tribunes and sometimes the walls are hung with splendid tapestries from that priceless collection belonging to the royal family, composed of the choicest products of the royal tapestry factory at Madrid and of the looms of 


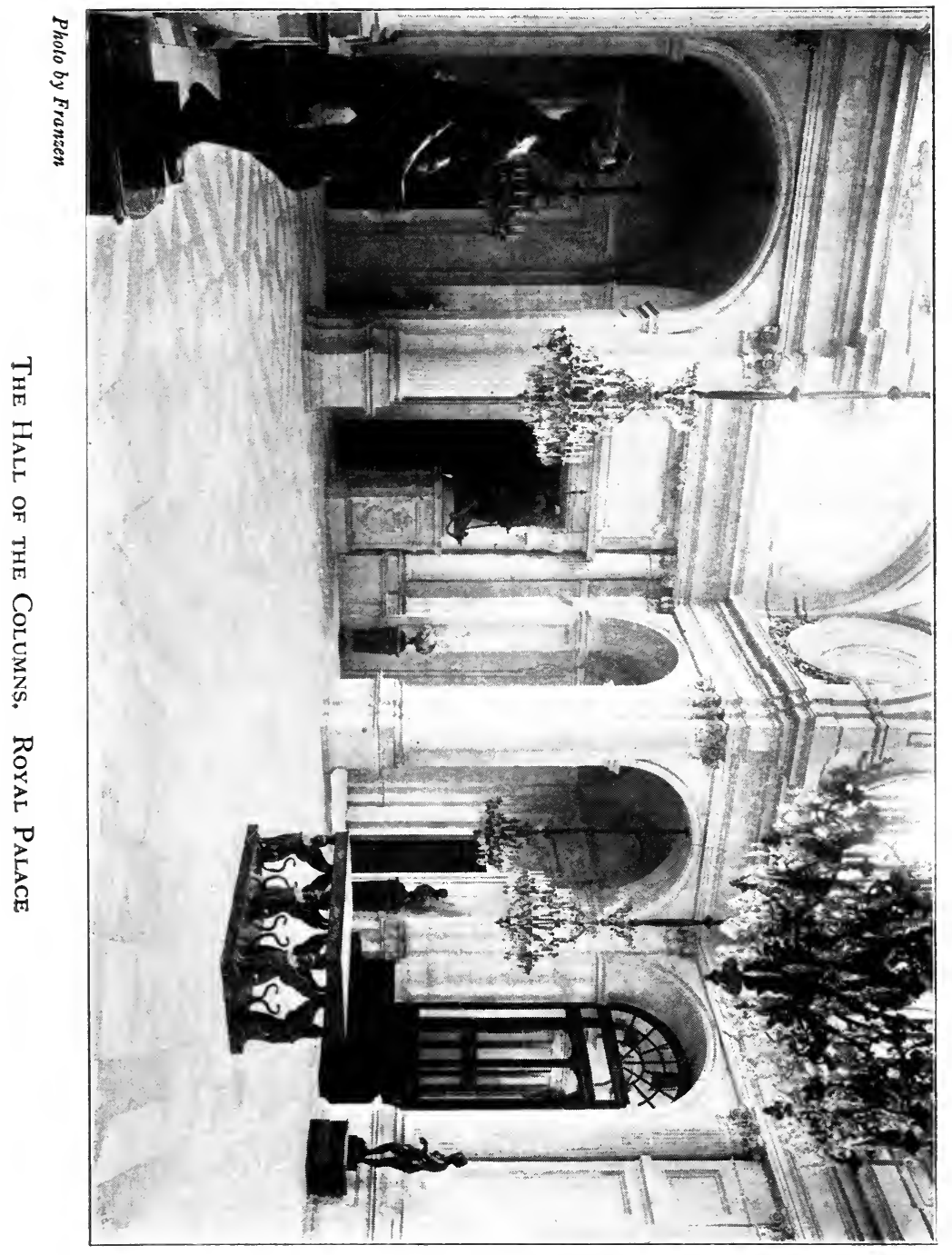


Flanders in the seventeenth century, when that country was still a Spanish province. The masterly tapestry in which Pannemaker portrays the Last Supper serves as a retablo for the altar which has been erected at the end of the hall, and which sparkles and gleams with all its lighted candles, whose flickering flames are mirrored and reflected in the finely wrought sacred vessels of purest silver, and in the polished bowls and jars and basins and ewers that are to be used in the service of the washing. At both sides of the altar halberdiers stand as sentinels, as motionless as if carved out of rock.

Tribunes have been erected along the sides of the hall. On the left, as we look toward the altar, is that for the royal family, flanked on each side by those for the Diplomatic Corps and the Ministers of the Crown. Back of the latter is one reserved for "distinguished personalities." On the opposite side is that for the five hundred or six hundred people who have been invited. The majority of them are women. They stand crowded closely together. Many of them have been there since early in the morning, anxious to be certain of securing a place in the tribune, and, if possible, a good position from which to view the ceremony. The ladies of the royal family, the ladies of the Queen, and those of the Diplomatic Corps all wear the classic mantilla, that form of headdress so characteristically Spanish, so gracefully becoming to them, and which on this day is obligatory by court decree and long-established custom. 
It is the hour fixed for the ceremony. The King with his retinue, which has been formed in the galleries surrounding the Grand Court, comes through the guard room and enters the Hall of the Columns. At the head of the procession are the clergy with uplifted cross and with lighted candles in their hands. Acolytes, choristers, deacons pass by us, and then come the functionaries of the court. Gentlemen in waiting, chamberlains, and lords of the bedchamber, all in court dress, march in, in solemn and stately procession. The ladies of the Queen accompany them if the Queen is to take part in the ceremony. Next come twelve of the most eminent of the grandees of Spain. These are to assist the King in the act of washing the feet and in serving at the table. Then comes the King himself, and immediately behind him are the Nuncio and the Grand Chaplain (the Bishop of Zion), who are to take important parts in the service. With a salute to the Diplomatic Corps and a profound reverence to the ladies of the royal family, the procession passes up in front of the altar.

Meanwhile through another door the thirteen poor men have entered. Poor, indeed, they are! Lame, halt, palsied, and blind are all to be found in that line. Each of them is guided and supported by two grandees of Spain and is escorted to the seat placed for him in front of the tribunes next to the altar. The spectator's sympathy is aroused by the sight of their infirmities, yet he can hardly repress a smile at the somewhat ludicrous or incongruous suits in which they are 
dressed. Every one wears a long black cape overcoat and a high hat of the shape and form of an American silk hat. If the Queen is participating, the twelve poor women whose feet are to be washed by her are escorted to their places by twelve ladies of the Queen, grandees of Spain, who also assist in serving them at the table.

The clergy and choir and acolytes have taken their places at the altar and the service commences. The Gospel is the chapter from St. John describing the Saviour's washing of the feet of the disciples. At the words posuit vestimenta sua ("he laid aside his garments"), the King hands his hat, gloves, and cane to a chamberlain who is near him, and then when the words precinxit se ("he girded himself") are read, another chamberlain brings an apron on a silver tray, and the Nuncio or the Bishop ties it around the King. When the words coepit lavare ("he began to wash") are pronounced, the King goes over to the place where the thirteen poor men are seated. Grandees of Spain unlace the shoe and remove it and the stocking from the right foot of each. At the left of the King, the Grand Chaplain holds a silver basin under the foot; at the right the Nuncio pours consecrated water upon it from a silver ewer, while His Majesty raises the foot, and with a towel wipes and dries it and, stooping over, kisses it. Quietly, reverentially, yet quickly, the feet of all are washed and the shoes are replaced.

Then, aided and escorted by grandees, these poor men are placed at the table where the dinner is to be served. It is set upon a raised 
274 THE COURT OF HIS CATHOLIC MAJESTY platform upon which the King and the grandees who are to assist him stand. The Nuncio and the Bishop are at the head of the table, and one of them pronounces the blessing. The table is covered with a white cloth. At each place are a knife and fork, a napkin, a salt cellar, a roll, and a huge carafe of wine. The scene is a reproduction of the Lord's Supper as portrayed by Leonardo da Vinci, for all the thirteen men are seated on one side of the table. Here they are to receive a repast of which, at the time, they are not to eat anything. Food and drink, literally by the ton, will be placed before them, course after course, but untouched by them it will be taken away, course after course, and sent out to another room, where, however, it will be placed in baskets (one for each person) and will be given to them afterwards. This food, which is piled up on many tables in the guard room, adjoining the Hall of the Columns, is not carried in, but is passed from hand to hand by the servants until it reaches the Hall of the Columns. Gentlemen of the House here take it and hand it from one to another until it reaches the platform upon which the table is placed. It is then handed to the first grandee, who in turn gives it to the King, who places it on the table before the poor man who occupies the first seat. That which is to be placed before the second passes from one grandee to another and then to the King, to be placed by him, and so on; the farther down the line the poor man sits, the greater the number of grandees through whose hands the food passes before it reaches the King. 
When a course has thus been served to all the thirteen, it is removed in a similar manner. The King takes it away from the first man and hands it to the first grandee, and from hand to hand it passes down the line of grandees until it reaches the outer room, where it is placed in the baskets which are afterwards to be given to the beneficiaries. No one but the King places the food on the table; no one but him removes it. Every one of the thirteen is served at every course, and as there are exactly twenty-five courses, simple multiplication shows that during the progress of the dinner His Majesty places three hundred and twenty-five plates or platters or dishes and removes a like number, besides clearing off the table at the termination of the feast and removing the knives and forks and all the other things with which the table is set. All the dishes are heavily laden. Think not that individual portions are served. If salmon is the course, each man receives not a slice, but a whole salmon. When queso de bola (ball cheese) appears on the menu, each one is given, not a small piece cut with a knife or with a cheese scoop, but a whole Edam cheese. If oranges are passed, it is not one for each person, but a whole fruitdish filled with a dozen or more. If nuts are the course, each man receives several quarts of each and every kind, not a few to be eaten at the table. Each plate or dish of each course is, therefore, enough and to spare for a whole family; so that the poor men who are compelled to abstain from eating during the ceremony may well feel recompensed 
276 THE COURT OF HIS CATHOLIC MAJESTY for the delay. All the food is cooked in the royal kitchen. The menu, which is always previously submitted to the King, contains no meat, for it is the Lenten season. But is there anything except meat which that menu does not contain? The sea has certainly given up its fish for this feast. Read the menu of the dinner of this day, Holy Thursday, March 28, 1907.

Omelet de escabeche with soused fish

$\begin{array}{ll}\text { Salmon } & \text { Rice with milk } \\ \text { Sea Bass } & \text { Edam Cheese } \\ \text { Fried Hake } & \text { Apples } \\ \text { Conger Eel, with rice } & \text { Oranges } \\ \text { Breaded Sardines } & \text { Citron } \\ \text { Soused Gilthead } & \text { Limes } \\ \text { Stuffed Artichokes } & \text { Candied Melon } \\ \text { Fried Cauliflower } & \text { Prunes } \\ \text { Broiled Mullet } & \text { Walnuts } \\ \text { Fried Sea-bream } & \text { Hazelnuts } \\ \text { Fried Sole } & \text { Anise } \\ \text { Olives } & \text { Pastry Tarts }\end{array}$

Everything mentioned in this list, even to the several different kinds of nuts, is served as a separate course, and it will be remembered for each of the thirteen persons there is enough for very many people. The pitchers of wine that are placed before them weigh nearly twenty pounds each. The King on this day certainly demonstrates his strength and his agility. La Epoca, the conservative Madrid daily, which treats nothing frivolously, said:

"On serving the poor His Majesty the King, with whom the grandees of Spain had some difficulty in keeping up, showed anew the vigor which he displayed some years ago at a similar 
ceremony, lifting in each hand jars of wine whose weight is quite respectable. One of the grandees, by reason of the rapidity with which he had to attend upon Don Alfonso in taking the food from the table, let a platter of walnuts fall, which produced on the mosaic floor a noise like the rattle of musketry, which joyfully broke up the austere solemnity of the ceremony."

After the wine has been served, to each of the poor is given a small bag filled with coins. When the courses are all served and the alms are distributed, His Majesty removes the entire table service; even taking off the tablecloth and folding it up. The royal party and the court then withdraw in the same order and with the same state as they entered. The thirteen poor men are then escorted from the table by the grandees and are conducted out of the palace and are put into the carriages which are to take them, with the baskets of food which have been served to them, to their homes. Each retains as his own property the clothes which were given him to wear at the ceremony. It is quite customary for them to sell the contents of their baskets. Sometimes the restaurant keepers buy them and display them in their windows. A former Secretary of the American Legation at Madrid, who resided for very many years in that city, assured me that so great was the popular desire to eat something which had been cooked in the royal kitchen that the contents of these baskets found a ready sale at very high prices, and that "American tourists were among the most eager purchasers." However true that may be, the propriety of the selling of these baskets by the poor men to whom 
they have been given is fully recognized, and so great is the demand that instances are by no means rare when the contents of the basket have been put up at auction at the very doors of the palace itself at the very moment that the beneficiary has left the ceremony.

In many other ways the solemn events of Passion Week are commemorated at the Court of His Catholic Majesty. On Holy Thursday and Good Friday practically all street traffic is stopped in Madrid. Until recent years the suspension was absolute. On the latter day everyone is dressed in black. On Holy Thursday the King complies with a very ancient custom. Dressed in full uniform, accompanied by the Queen, all the members of the royal family, the Court, the halberdiers, and the Escolta Real, he visits seven of the principal churches, going from one to another, on foot. On Good Friday the King and the entire court attend service in the Royal Chapel. In the act of the Adoration of the Cross the King exercises his prerogative of pardoning condemned murderers. The Bishop of Zion presents to the monarch the petitions of those whom it has been decided to pardon. They are tied with black ribbons. The Bishop says to the King: "Does Your Majesty pardon these criminals, who have been condemned by human justice to suffer the extreme penalty?" The King answers: "May God pardon me as I pardon them." Thereupon the assistant of the Bishop substitutes white ribbons for the black ones. At the close of the service there is a solemn procession of the Most 
Holy in the interior of the chapel, in which the King and his retinue join. Afterwards the royal family repair to the salon of Gasparini, a room in the palace whose walls and ceilings are covered entirely with the finest and most delicately fashioned porcelain. Here certain relics are, on this day, exhibited; among them are a piece of the true cross and one of the nails from it.

Good Friday afternoon the procession of the "Burial of Christ" passes from the church of San. Gines, through the Calle Arenal, the Puerta del Sol, the Calle Mayor, to the palace, and then back to the church. Pasos, or sculptured representations of the Saviour's passion and death, are borne on the shoulders of the members of religious societies. All the priests of the city and hundreds of monks and nuns are in the procession. The Nuncio presides over the clergy, and the bishops accompany him. The Royal Halberdiers form the guard of honor for the Christ. The Knights of Calatrava accompany the paso of the Sepulchre. The State unites with the Church, and the parade is as much military as ecclesiastic. The Civil Governor is there in his official capacity, as chief of the procession. The Mayor and other city officials are conspicuous among those in line. Regiments of infantry with bands of music and mounted police, and the Guardia Civil follow the pasos. The royal family does not take part in the procession, but, surrounded by the Prime Minister and all the other Ministers of the Crown, they review it from one of the balconies of the palace. 
280 THE COURT OF HIS CATHOLIC MAJESTY

On Saturday morning of Passion Week there is a service in all the churches of Madrid, called the breaking of the veil or curtain, commemorative of the rending in twain of the veil of the Temple on the day of the Crucifixion. From that moment Lent ceases in Spain, this Saturday being called Sábado de Gloria (Saturday of Glory). On every Saturday throughout the year the royal family go in the afternoon to the church of Buen Suceso to attend the Salve. Formerly, for many centuries, they went to the church of the Atocha for this purpose. Their progress from the palace to the church is quite an imposing pageant, for they go in full state, in many carriages, accompanied by all the "high service" and by lords and ladies in waiting and escorted by the splendid troop of the Escolta Real.

On Easter Sunday it is traditional for a paschal lamb to be carved at the King's table. It is a combined religious service and state ceremony. The Bishop of Zion, Grand High Chaplain, celebrates a service of benediction for it in the chapel, and it is served at the royal table with great formality. 


\section{CHAPTER XVI \\ A Palace Ball}

DUING the long years of the minority of Alfonso XIII the Court of Spain was not the scene of festivity. Maria Christina, the mother, was preoccupied with the care of her young son, whose education and physical development were her constant thought. Maria Christina, the Queen Regent, was too much burdened with the serious affairs of state to give much attention to soirées, court balls, and garden parties. The great ceremonies were observed with stateliness and seriousness. "Their meaning and significance were never better interpreted. No one was more punctilious in the observance of the 'etiquette than the Queen Regent; no one performed the sovereign's part with more dignity and grace and distinction than she; but mirth was a stranger to the palace. Grand social functions were unknown, and in the opinion of the gay world that basks in the sunshine of royalty's smile, Madrid was muy triste, - a very sad and forlorn sort of a place indeed. The balls given at the time of the wedding of the Infanta Maria Theresa were an oasis in this social desert. They were the sign of a tendency to rejuvenate the court. But no permanent change was effected until the marriage of the King. When the young 
sovereign, not then twenty years old, took a bride still younger than himself, it was expected that a marked change would take place. There was no one who anticipated this with greater pleasure than Maria Christina, the Queen Mother, whose whole life seemed bound up in the happiness of her children. The royal marriage did, in fact, make the court brighter and more gay and more cheerful, and exercised a profound influence on Spanish society in general.

I have stated elsewhere that the grand ball which had been planned as one of the King's wedding festivities was cancelled because of the mourning in Madrid occasioned by the death of many persons who were killed by the anarchist's bomb. It was not until twenty months latermany months after the birth of the Prince of Asturias - that the sovereigns gave a ball, the first which Queen Victoria attended in Spain. Although this great event had long been anticipated by all who were, or who aspired to be, of the haut monde, the invitations, according to the custom of the Spanish court, were not issued until two or three days before the date that was fixed for it. Thus ran these invitations:

\section{Office of the}

Lord Chamberlain.

By order of His Majesty (whom God guard) I have the honor to invite you to the Ball which is to take place in the Royal Apartments, the twenty-fourth of the current month of January, at' half-past nine o'clock at night.

Palace, twentieth day of January, I908.

P. Duke of Sotomayor.

Lord Chamberlain. 
Note.-The gentlemen, in gala uniforms, or if not having uniforms, in evening-dress coats with knee breeches and black stockings. Ladies, décolletées, and wearing the bands of any orders to which they may belong.

The ushers will collect this invitation at the door. It is personal and not transferable.

At the hour fixed, or even earlier, practically every guest had arrived. Promptness may be, in the language of Louis the Great, the virtue of kings. It is certainly a duty for those who are invited to the palaces of kings. Furthermore, the passage of the royal party from their apartments, through the salons crowded with guests, to the ballroom, to open the fête, is, in itself, no small pageant, and is always especially attractive to the female sex. One, therefore, who fails in his duty and comes late pays the penalty.

We had entered through the Plaza de Armas and had ascended by the grand staircase. At its foot we had a glimpse of the color and the gala that were to be seen everywhere all the rest of the evening. The Concierge-in-chief was arrayed in the most gorgeous of scarlet liveries, with the broad galon of the Bourbons and a sash or band, at least six inches in width, running loosely about his body, from the right shoulder to the left hip. He held in his hand a massive staff with an enormous golden ball on top. It was several times as large as any drum-major's baton, and with it he pounded twice as a salute to each distinguished guest. On every step of the grand staircase servants were stationed - nearly two hundred in number. All were in blue liveries, long cutaway 
284 THE COURT OF HIS CATHOLIC MAJESTY coats, knee-breeches, and red stockings, and all had powdered their hair. On the landings the halberdiers gave the customary salutes with their halberds. We passed through the Hall of the Guards into the Hall of the Columns, where wraps and coats were laid aside, and then went to join our diplomatic colleagues in the throne room, to await the royal family, while the other guests assembled for the same purpose in other salons.

It was veritably a dazzling sight even before the ball commenced. The doors between the salons were open, and we could look from one into many others in a long and almost interminable series, multiplied infinitely by the reflections from the many mirrors that covered the walls. Thousands of lights gleamed and shone in the enormous rock-crystal chandeliers which lighted up and brought out the colors of picture and tapestry and gilded furniture and painted ceilings.

It was a scene of beauty and of animation. Grouped together were at least a thousand men in splendid uniforms or court dress and more than a thousand ladies in their handsomest gowns. It was a kaleidoscope of shifting color. Rich jewels sparkled and scintillated as the beams of light struck them. Everyone was talking and moving about; friend was greeting friend. All were on the qui vive. Suddenly the ushers passed through the salons clapping their hands. It was the signal that the royal party was approaching. People became silent and fell back, leaving a passageway: Bowing right and left, the royal 
personages passed, leading the way to the Grand Hall of Festivities, or Grand State Dining-Room, where the ball was to be held. First came the Queen upon the arm of her cousin, Prince Arthur of Connaught, who was visiting King Alfonso at the time. The Queen was unquestionably beautiful and veritably regal in a long white satin dress. She was wearing a diadem, a collar, brooches and long pendant earrings, all composed of diamonds and turquoises. Over her breast was crossed the purple and white band of Maria Louisa and she wore the insignia of two other orders. Her royal cousin was a striking figure in his showy uniform, with the Spanish Order of Carlos III. Then came the King, escorting his mother. He wore a captain general's uniform, the Spanish Order of the Golden Fleece, and, in compliment to this British guest, the Order of the Garter. Queen Maria Christina was handsomely dressed, with her habitual elegance and perfect taste. She is famous for the value of her jewels, and those she wore that night were correctly described by the society reporter of one of the Madrid papers as "magnificent diamonds and enormous pearls." Infanta Isabella, escorted by her nephew the Infante Don Fernando, came next. He was in the gay uniform of the Hussars of Pavia. She was richly dressed and jewelled and wore the bands of the Spanish Order of Maria Louisa, the Bavarian Order of Saint Elizabeth, and the Austrian Order of Maria Theresa. The same orders were worn by the Infanta Maria Theresa, who followed on the arm of 
286 THE COURT OF HIS CATHOLIC MAJESTY

Captain Wyndham, aid of Prince Arthur of Connaught. With the princes and princesses were the Ministers of the Crown and the Palace Chiefs.

The Diplomatic Corps fell in line behind the royal family. Back of them all the other guests came, crowding each other, so anxious to miss nothing that ladies knocked down the temporary railing that had been erected in the centre. of the room to reserve space for those who were to dance the rigodon de honor. With this dance all state balls in Spain are opened. Magnificent was this great ballroom with its gigantic marble pillars, its beautifully decorated ceilings, its sixteen stupendous crystal chandeliers, its tapestried walls, its beautiful decorations, and the brilliant assemblage that was crowding it to the utmost, despite the fact that it is said to be the largest ballroom in any palace in Europe. The royal party took seats upon a raised dais that was erected at one side of the room.

All of them except Queen Maria Christina took part in the rigodon de honor, and with them danced the ambassadors and ambassadresses, the oldest of the Ministers Plenipotentiary and their wives, the Palace Chiefs, the Grand Mistress of the Robes, the ladies in waiting, the Minister of State, and the presidents of the Senate and of the House of Deputies. There were four couples at the heads and four at the sides. The stateliness and ceremoniousness of this quadrille as danced in Spain is very interesting to see. Be it said to the credit of the official world of Madrid 


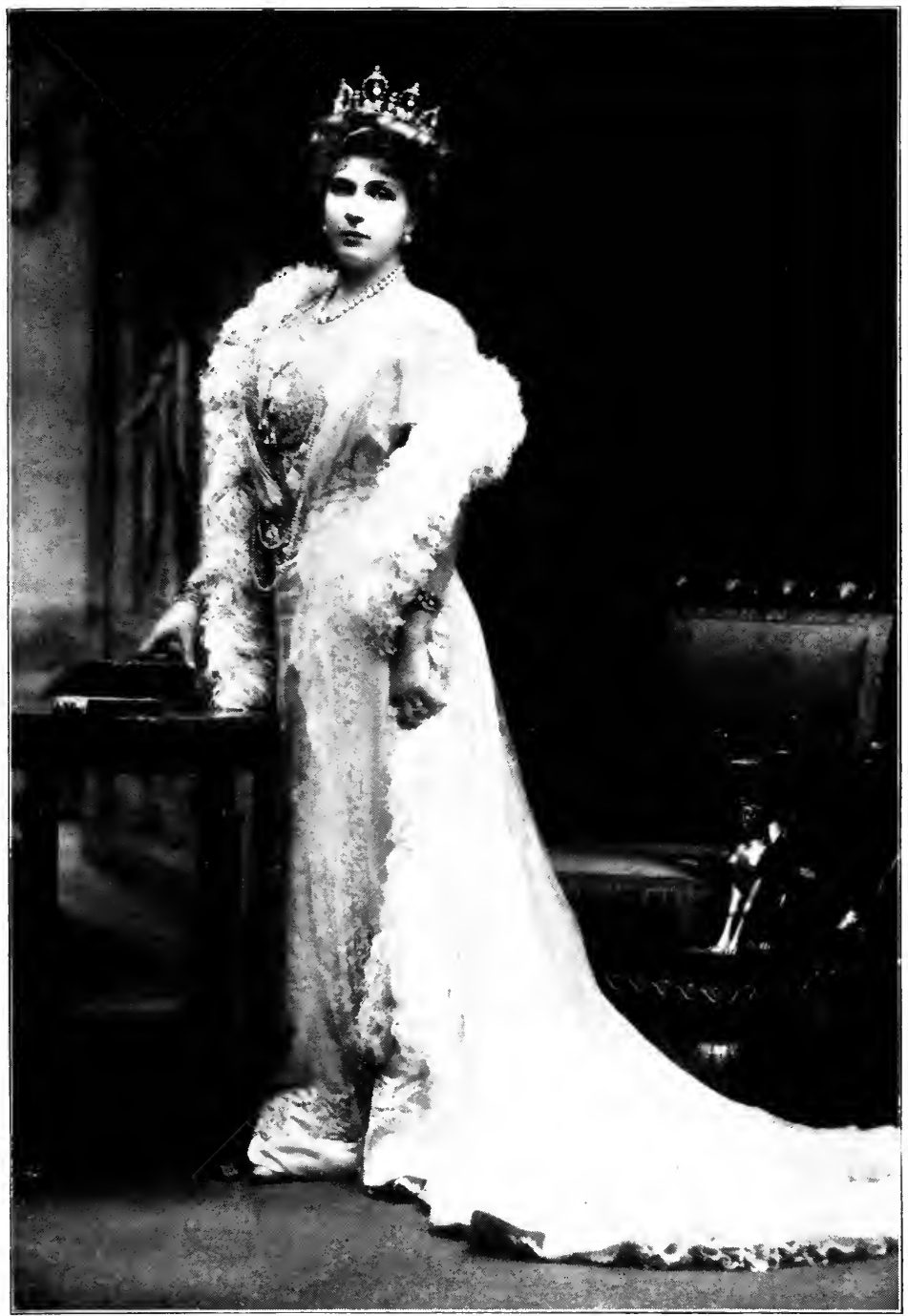

Photo by Kaulak

Her Majesty, Queen Victoria in 1909 


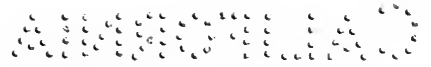


that all knew its every figure and every step. Its beauty was never marred by mistakes or faux pas. The King danced it with military precision, with dignity, and with ease. I could not help recalling what he had said to me before the Duchess of Bailen's ball about his not knowing how to dance. Not only did he dance the quadrilles, but, with absolute correctness, with enthusiasm and tirelessness, he took part in the mazes of the waltz and in the quick step of the galop, favoring many of the ladies by inviting them to be his partners, and putting life and vim into everything. Dance followed dance in constant succession. The Queen participated in a second quadrille, but not in any round dances. The Infanta Maria Theresa took part in several quadrilles; while the Infanta Isabella, the King's aunt, entered heartily into the dancing, with her usual cordiality and simpatia, making every one feel at ease, enjoying everything herself, and endeavoring to give everyone else a good time.

The music was by Barbero's well-known orchestra, which was hidden in a mass of palms and plants concealing a platform that had been erected at one end of the ballroom. Many of the selections were new to Madrid. "The Merry Widow" and "The Gordon Girls" made their début at the Spanish court that night. Was it Queen Victoria who summoned them from abroad, or that lover of good music and patroness of musicians, the Infanta Isabella? Probably both. In any event, the royal ball that night was not cold 
288 THE COURT OF HIS CATHOLIC MAJESTY or formal or stiff. La Epoca of the next day was not wrong when it said:

"It was a ball full of animation, in which the King and Queen were constant participants and actors, like two young married people who amiably receive their friends."

When not dancing, the members of the royal party were generally seated on the raised dais, where, now and then, guests who had not yet been presented to the Queen Mother or to the Infantas were conducted by the Introducer of Ambassadors for that purpose. Several times during the evening the clapping of hands by the ushers announced that the King and Queen or the Infantas were walking through the salons. A way was opened for them, and as they passed they stopped and conversed with the persons whom they recognized.

All Madrid "society" was at the ball. To enumerate the guests would be impossible. Equally impossible would it be for me to describe the magnificence of dress, the splendor of jewels, the beauty and grace of the ladies who were present. Yet how incomplete, how empty, would be the account of a ball that did not give some idea of these important matters! Since my own pen fails me in this respect, let me quote from an account which appeared in the columns of one of the most ably and conservatively edited papers of Madrid, whose social chronicler possessed the combined powers of observation, appreciation, and description. This will give you not only a picture of a Spanish court ball, but a specimen of the exuberance of Spanish journalism and a 
revelation of the gallantry of Spanish cavaliers and of their almost Oriental fondness for all that is rich and costly and splendid.

"Madame Revoil, wife of the French Ambassador, was wearing a dress of bright green, embroidered in gold and silks of various colors, also a collar of pearls. Of gray trimmed with magnificent lace, was the gown of Sigñora Silvestrelli, wife of the Italian Ambassador. Very elegant, with diamonds and pearls, was the Señora de Rendon, wife of the Minister of Ecuador. In crimson velvet, with handsome jewels, was Lady de Bunsen, the British Ambassadress; in white satin, with iridescent embroidery, and wearing a diamond tiara, was Mrs. Collier, wife of the American Minister; Señora de Wilde, wife of the Argentine Minister, was handsome in a rose-colored dress embroidered with silver, and as ornaments she wore diamonds and sapphires. Señora de Beistegui, wife of the Mexican Minister, wore a dress of black velvet, the bodice of which was covered with net diamanté, and in her coiffure was something resembling a blue turban in which was twined a chain of pearls, which reminded one of the portraits of Madame Récamier. The elegant figure and great beauty of the Marquesa de la Mina, one of the ladies of the Queen, were set off by her pale blue dress diamanté, and she was wearing as ornaments some of the magnificent pearls of her collection. In white, with jewels of diamonds and sapphires, was the Dowager Duchess of Bailen, a lady of the Queen. Upon her head was the great Russian tiara of diamonds which she wears only on grand occasions. Very elegant was the Countess of Casa Valencia, a lady of the Queen, with her magnificent emeralds. In a dress of silver gray embroidered with lace was the Marquesa de la Viana, wife of the Grand Master of the Horse. She wore as ornaments a beautiful Cartier collar and a diadem whose fine workmanship accredited it as from the store of that distinguished Paris jeweller. The Marquesa de Ivanrey was most elegant in a dress of royal blue tulle. Strings of pearls formed a trimming for the bodice, and she displayed also a magnificent tiara of diamonds and emeralds. 
The Marquesa of Squilache wore a magnificent white dress covered with spangles of silver. She had, as ornaments, magnificent pearls and a great closed crown of diamonds. The Baroness Castillo de Chirel wore around her neck a superb net of diamonds, and her dress was encircled with a belt of diamonds and emeralds."

In this superlative manner the description continued for several columns of the paper. Names and titles by hundreds were mentioned; jewels sufficient for the ransom of all the kings of the world were described. No wonder the reporter, in despair, said of himself: "The chronicler loses consciousness in this whirl of feathers and dainty fabrics and sparkling jewels, and dizzy and bewildered, can hardly recollect more details."

Very many others, tired of the dancing and wearied by the dazzling spectacle in the crowded ballroom, sought rest and quiet in other salons. The room adjoining the ballroom had been fitted up as a drawing-room. Magnificent tapestries had been hung on its walls. A great section of the glass-enclosed galleries which run round the grand court of the palace had also been decorated with tapestries and a long buffet set therein, where hundreds at a time could stand and eat. Here very many came for refreshments and the cooling drink. The royal personages with their suites, and the ambassadors and their wives, according to a recent innovation in the court etiquette at Madrid, sat down alone to supper, which was served them in a separate room.

And there was still another form of rest and diversion for those who wished to escape for a 
time from the excitement and the movement of the ballroom. It was found in promenading through the salons of the palace, in viewing and examining its architectural details, its splendid furniture, its excellent pictures, its priceless tapestries, its rare faïence, and its myriad of other objects of art. Let us take this promenade. From salon to salon - thirty-five in number on this one floor - one can wander, always finding new fields of exploration, filled with things to fascinate and delight. There are pictures by Velasquez, Ribera, Carreño, Mengs, Vicente Lopez, Goya, Giordano, and scores of others, although the best paintings were sent away to the Prado Museum by Fernando VII, who preferred French silk wall-coverings that may be bought by the yard to works of art whose merit and whose actual market value it would now be difficult to over-estimate. But if Fernando VII banished pictures, he welcomed clocks. With him and his father, Charles IV, clock collecting was more than a fad; it was a veritable mania. The former spent much of his time in trying to make his clocks keep time. In every room of the Royal Palace there are many clocks, - large and small, marble and metal, of every design and conceit, and yet there are fewer here than in that little bijou palace or pavilion at the Escorial, known as the Casita del Principe, or in the Casa del Labrador at Aranjuez, where a dozen and sometimes more may be seen in rooms which are not ten feet square.

Most of the tapestries, of which there are over eight hundred in the royal collection (the richest 
in the world), are generally stored away in mothproof and fireproof rooms, but the best of them are brought out and hung up on fête days, and are truly magnificent. Universally admired is that series of eight (originally ten) woven in Brussels by Pannemaker, portraying the Crusade in Tunis of the great Emperor Charles the Fifth (King Charles I of Spain). One stands almost amazed before another series of six pieces representing scenes from the life of the Virgin, worked in soft harmonious colors upon a foundation which is a solid mass of gold threads, and in delight one examines that series which portrays the life of Saint Paul as first depicted in color by Blomaert. No less admired are "The Bearing of the Cross," after Roger van der Weyden, and "The Temptation of Saint Anthony," after Bosch. Millions of dollars is a low appraisal of this collection, of which we have mentioned only a very few specimens.

But besides the tapestries, which are the rarest works of art in the palace, one can see very much that is interesting. The Salon of the Mirrors has hardly a foot of wall space which is not covered with magnificent mirrors. Beautiful Sèvres vases on high pedestals also adorn this room. One can pass from here into the Salon Gasparini. Rich brocade of pearl-gray silk with white and pink roses in high relief adorns the walls. 'The ceiling is entirely covered with flowers and fruits and garlands of faïence, fashioned so cleverly that one cannot tell where brocade ends and faience begins. From this room one can enter another, whose walls and ceiling are adorned with cherubs of the 


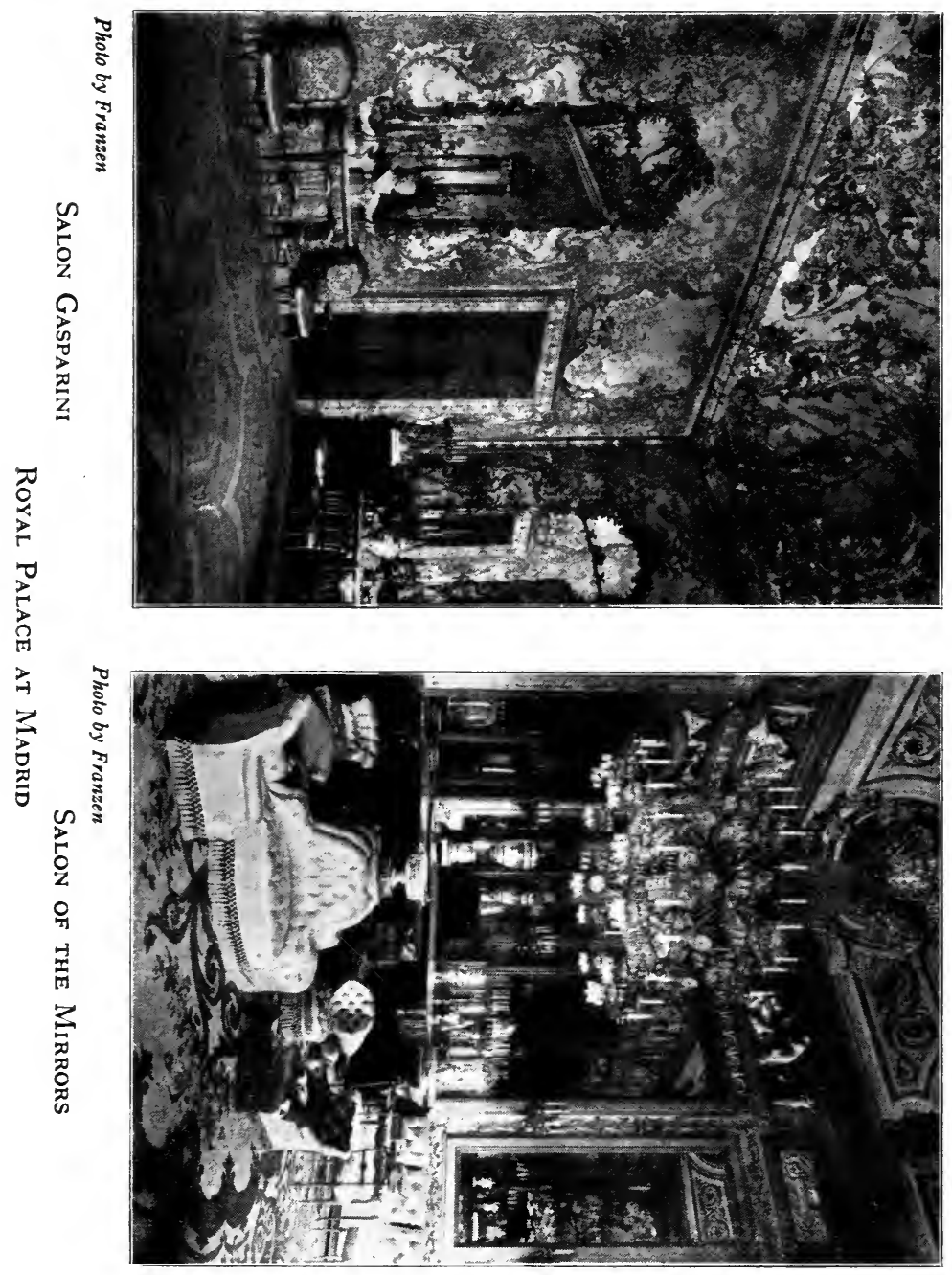




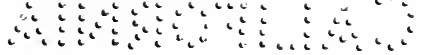

2 
white pottery, pâte tendre, made in the famous Retiro porcelain factory of Madrid, long since destroyed. We may wander from here into the Salon of Charles III, where the portrait of that monarch by Raphael Mengs adorns the walls, which are hung with blue satin spangled with silver stars.

Each salon has its distinctive color - sometimes a little striking and bizarre - and each has furniture of a different epoch. We may pass through a Louis Quinze room hung with exquisite old rose satin into a Renaissance room whose walls are covered with red and bordered with gold, and from that into still another, where we see a remarkable combination of pale green blended with saffron yellow, and then into the Empire Room, with its severe but elegant furniture, its walls being covered with blue heavily embroidered in gold. In all these salons there hang giant chandeliers whose crystal prisms reflect the light and dazzle the beholder. In each room, doors and windows are framed in agate or marble or precious woods, whose color and whose veining harmonize with the color and the pattern and the figures of the furnishings. But one must return to the ballroom, to dance again or to look on, and to wait there until the King and Queen leave, for no guest must depart so long as Their Majesties remain.

It was a quarter after one o'clock. The orchestra struck up a galop and the King, with the Infanta Maria Theresa as his partner, danced it with a vim and an energy that gave no sign 
294 THE COURT OF HIS CATHOLIC MAJESTY of fatigue. Others joined in, until the floor was filled. It was the last dance. The music stopped. The ball was over. The royal family passed through the salons to their apartments, bowing good-night to their guests, who forthwith took their departure. 


\section{CHAPTER XVII}

\section{Royal and State Funerals, Court Mourning}

T $\mathrm{N}$ the month of August, 1905, the little Infante Don Fernando, son of the Infante Don 1 Carlos and of the King's deceased sister, Maria de las Mercedes, died at Miramar Palace, San Sebastian. I was spending the Summer at that place, having gone there, as had most of my colleagues; in obedience to the long-established rule to "follow the court," recognized as binding upon the representatives of foreign countries who are accredited to reside "near the person of His Majesty."

The little prince whose life was thus so prematurely ended was not quite two years and six months old. He was, however, second in succession to the throne, his brother, who was only a year older, being the heir presumptive, King Alfonso not then being married. For nearly a year he had been sick, and his final protracted illness was marked by intense suffering. Everyone felt the keenest sorrow for him, and when he died the expressions of sympathy sent to the royal family were many and sincere.

The funeral of a prince of such high rank, despite his tender years, had to be in accordance with the strict ceremonial of the court, and interment could be made only in the Pantheon of 
296 THE COURT OF HIS CATHOLIC MAJESTY the Infantes, in that massive building - church, monastery, college, palace, and royal burial place - which Philip II had caused to be erected at the Escorial on the edge of the Guadarrama Mountains, thirty miles from Madrid. Precedents as to ceremonies at the funerals of Infantes were carefully examined and scrupulously followed. The official notice of the death which was published in La Gaceta shows with what formality everything was conducted. Under the caption, "The President of the Council of Ministers to the Under Secretary of the same," one read as follows:

SEÑOR:

The Most Excellent Señor, the Lord Chamberlain of the Palace, communicates to me the following:

"Most Excellent Señor:

The Most Excellent Señor, the Grand Chamberlain, Chief of the House of His Royal Highness, the Most Serene Señor Infante Don Carlos, on this day, communicates to me the following:

“Most Excellent Señor:

With profound sorrow, I inform Your Excellency that His Royal Highness, the Infante Don Fernando, died at 7:55 o'clock to-day, in consequence of the meningitis from which he has been suffering.

Duke of Vistahermosa.'

"This by the order of His Majesty, I have the sorrow to communicate to. Your Excellency for your information and for such action as should follow. God guard Your Excellency many years.

Palace of San Sebastian, August 14, 1905. P. DUKe OF Sotomayor. P. DUKe OF Sotomayor.

To the Señor

President of the

Council of Ministers." 
This I transmit to you in order that due publication thereof may be made in La Gaceta of Madrid.

E. Montero-Pios,

President of the Council of Ministers.

There also appeared in La Gaceta another letter of the Lord Chamberlain to the President of the Council of Ministers, informing him that His Majesty had charged him (the Lord Chamberlain) with the duty of conducting the body of the Prince to the Escorial, "delivering it with the formalities and customary ceremonies at the Royal Pantheon of Saint Lawrence." With this letter was the command that due notice should be given to the civil and ecclesiastical authorities who ought to attend the funeral, and to the generals in command of the troops who ought to line the route of the funeral processions, "in order that, at San Sebastian as well as at El Escorial, there may be rendered to the royal corpse of the deceased the honors which correspond to his high position." La Gaceta also published the notice fixing the hour for the Misa (Mass) de Gloria in the parochial church of San Sebastian, "present the body of the deceased Infante," and inviting the Senators and Deputies, the Common Council of San Sebastian, the provincial authorities, and various other Government functionaries to attend in uniform of media-gala. A further official announcement was made as to the persons who should appear in the funeral procession from the church to the station at San Sebastian, and in what order they should march.

On the morning after his death, the white- 
298 THE COURT OF HIS CATHOLIC MAJESTY covered, gold-bordered coffin of the Infante was borne from the Palace of Miramar to the little parochial church just outside the palace gate. Clergy with cross uplifted preceded it. The "high service" of the royal house and others of the court followed, but none of the royal family were present; for it is not customary in Spain for those who are most nearly related to appear in these processions. From the balcony of the palace the grief-stricken members of the royal family watched the sad procession to the church and cried their last adieus. The Prime Minister and other governmental authorities, including the City Council with its mace-bearers, met the funeral party at the door of the church. The coffin was borne in and placed on a catafalque in front of the altar. After the mass had been celebrated the body was exposed to view for several hours.

Early in the afternoon the funeral cortège was formed and sadly wended its way through the streets of the city. Flags were at half-mast, of course; cannon in the forts on the hills above the bay boomed out the last salute. The route was lined with soldiers, who stood at attention as the procession passed. First came a detachment of the mounted Guardia Civil; then, on foot, the servants of the royal house and stables. The clergy, in their vestments, came next, with cross uplifted. Gentlemen in waiting and chamberlains followed them. Then came mounted soldiers immediately preceding one of the royal carriages in which was the tiny coffin of the baby Prince, covered with flowers and wreaths. At 


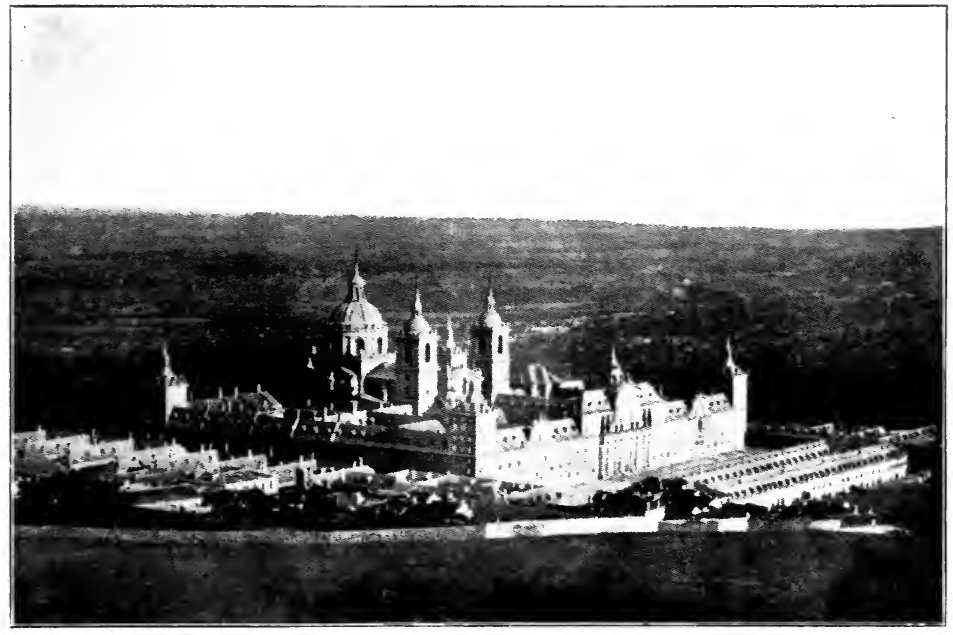

The EsCORIAL

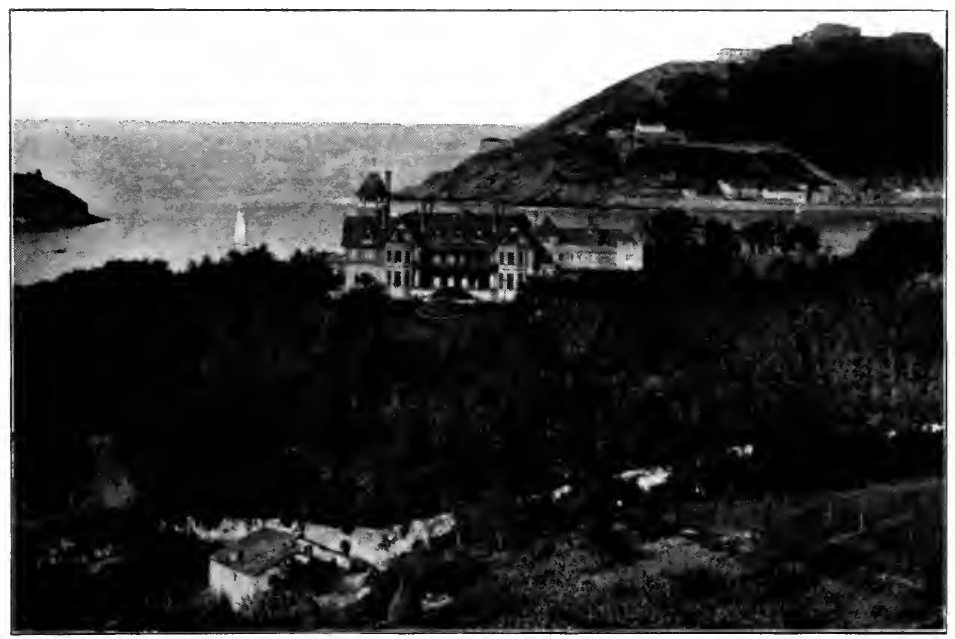

The Royal Villa of Miramar at San Sebastian 


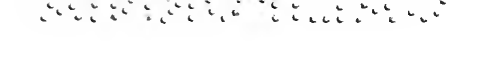


the sides of the carriage rode an equerry of the King and an officer of the Escolta Real. This splendid squadron served as the escort and rode immediately behind the dead. Then the Lord Chamberlain of the Palace and the Grand Chamberlain of the House of the Infante Don Carlos and the military aids of the latter followed on foot, constituting the duelo or official mourners. Infantry brought up the rear. The City Council, provincial authorities, and all the other governmental organizations had gathered at the station when the procession arrived there. The band played the Royal March; the troops rendered appropriate military honors, and the train left for the Escorial.

Delegations of grandees, the Grand Chaplain and the clergy of the Royal Chapel of Madrid, and the "high service" of the palace, who had gone from there to the Escorial, awaited the funeral party at the station in the latter place when it arrived there the next morning. The clergy of the little village of Lower Escorial, its town council, and the Augustine monks were also there. Halberdiers, carabineers, and municipal guards were drawn up along the platform when the train arrived. Outside were a squadron of horse, a battery of artillery, and a battalion of infantry. As the train came to a stop the band played the Royal March. While the little casket was being taken out of the car, the Bishop read portions of the service and the priests of Lower Escorial chanted the responses.

A procession similar to that which had passed 
300 THE COURT OF HIS CATHOLIC MAJESTY

through the streets of San Sebastian the day before was formed. In it was the coche estufa (hearse) belonging to the royal coach house. The horses that were to draw it wore on their heads crowns which served to hold great plumes of white feathers. There was also in the procession the customary coche de respeto, and besides this there were several carriages for the persons who were to form the funeral party. These carriages, however, went empty on the way to the burial place; for in Spain everyone, whatever be his age or his rank, follows the dead on foot. It is only upon the return from the grave, after the last farewell to the departed, that one rides in a carriage.

Four Monteros de Espinosa, members of that small but ancient body whose traditional duty for centuries has been to watch over the kings in their slumbers at night and to guard their bodies after death until placed in the tomb, bore the coffin of the baby Prince from the station to the hearse, and throughout the march to the Escorial walked beside it and held the long ribbons that extended from its top.

Troops of all arms of the service had been sent from Madrid and lined the way leading from the station at Lower Escorial, a mile or more up the hill, to Upper Escorial and the monastery and Pantheon. Cannon were fired as the cortège slowly started. The priests of the Lower Escorial formed part of it until they came to the limits of their parish. There, chanting a portion of the service for the dead, they gave the body over to 
the priests of Upper Escorial, and the procession continued on up to the gates of the massive building within which is the burial place of Spain's royal family. The Lord Chamberlain knocked on the heavy door and demanded permission to enter.

The prior stood inside, surrounded by all the monks. "Who demands entrance?"

"In the King's name, I demand entrance for His Royal Highness the Infante Don Fernando."

The body was then admitted to the church and was carried up to a catafalque placed in front of the altar, where again a Misa de Gloria was sung.

Exactly beneath the high altar of this church, down two flights of stairs, is the Pantheon of the Kings. It was planned by Philip II in fulfilment of his promise to his father, Charles the Fifth, to erect a burial place for him and his descendants; but it was not completed until the year 1654, in the reign of Philip IV, although other parts of the Escorial were completed and occupied by Philip II long before his death, which took place therein. Philip II caused the burial vault to be placed directly underneath the altar, in order that every day the Host might be elevated above the bodies of himself and the others of his House who might be buried there. All the kings of Spain, beginning with the great Emperor Charles the Fifth, except Philip V and Fernando VI, lie buried in the marble sarcophagi which, set in four tiers of niches, fill the walls of this sombre octagonal room. One can count thirtytwo of these marble coffins. They are for the dead and for those still living. All but four of 
them are now filled; for besides kings, the wives of kings who were the mothers of children who became kings are buried in this room. Queens who were childless or whose children did not come to the throne are buried along with the infantes in another room called the Pantheon of the Infantes. But before the body of either king or queen or infante is finally placed in its marble sarcophagus in the Pantheon, it is put in a low, dark, and poorly ventilated room called the pudridero. I hesitate to translate the word, because all the horror of death is expressed in it. Sufficient to say that it is here that decomposition takes place, and the bodies are left in this room for years until that process is completely finished. Then they are transferred to the Pantheon and placed in the sarcophagi which have been reserved for them.

As soon as the Misa de Gloria has been finished the coffin is carried by the Monteros de Espinosa to the door of the pudridero. There it is placed on a bier, and in the presence of the Minister of Grace and Justice, or his delegate, as Chief Notary of the Realm, the Lord Chamberlain asserts, and in due and ancient form gives proof of, the decease of the Infante, his lineage, and his right to interment in that place of burial reserved for those of royal blood. The long detailed record of the proceeding is then read and signed by the official witnesses and the Lord Chamberlain gives to the prior of the monastery the key to the casket, while the Monteros de Espinosa carry it down into the dark chamber, 


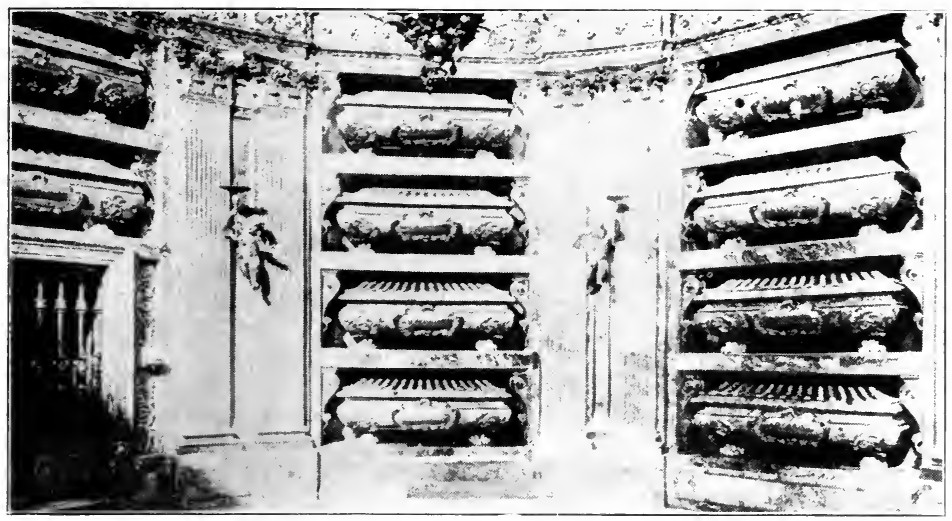

The Pantheon of the Kings at the Escorial

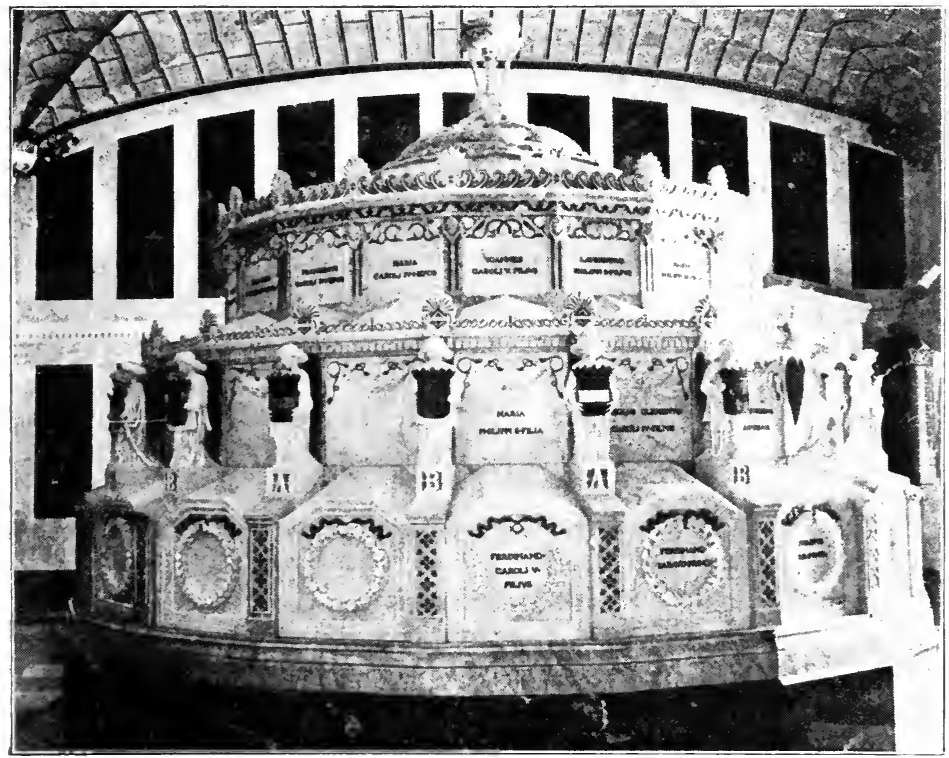

The Pantheon of the Infantes at the Escorial 
where the body is to remain for five or more years, when, decomposition having taken place, it will be transferred to the sarcophagus prepared for it in the white marble-floored, and marble-walled Pantheon of the Infantes where so many of the Habsburgs and Bourbons sleep their long sleep.

When the funeral is that of a king, the Lord Chamberlain, according to the ancient custom, is required to take the key of the coffin, unlock it and, bending low over it, cry loudly in the ear of the king three times: "Señor! Señor! Señor!" Nothing but echo answers in the vault of that hollow room. Slowly rising, the Lord Chamberlain solemnly says: "His Majesty does not answer. Then is the King indeed dead." Locking the coffin, he gives the key to the prior, breaks the small rod or cane which he carries as his insigne of office, throws the pieces on the floor at the foot of the coffin, and goes away.

When a member of any royal family dies, the fact is officially communicated to all the other courts of the civilized world, and also to the presidents of all republics. Immediately court mourning is ordered in every court of Christendom. Thus, whether it be the Czar of all the Russias or the cousin of the Emperor of Austria, the wife of the Prince of Monaco or the third son of the Grand Duke of Mecklenburg-Strelitz, any member of any royal house, - the Court of Spain will go into mourning for a period, long or short, according to the deceased's rank and relationship to the royal house of Spain, but absolutely determined by fixed rules, and not varied 
304 THE COURT OF HIS CATHOLIC MAJESTY

by intimacy of acquaintance or closeness of personal friendship. This rule does not apply when presidents of republics die, nor in the case of monarchs of non-Christian countries, although the Emperor of Japan ordered his court into mourning for three weeks when Alfonso XII died. Neither do courts, even in the most Catholic countries, go into mourning when a pope dies, although funeral services are held for him at St. Peter's in Rome, in which the cardinals appear in robes of mourning such as they wear in Lent, and the diplomats accredited to the Vatican wear mourning. In Spain mourning is not ordered when the deceased is less than seven years old. Consequently the court did not go into mourning when the little Infante Don Fernando died. Court mourning means that all the royal family, all of the very numerous personnel of the royal household, all the gentlemen and lords in waiting, all the ladies of the Queen, all the grandees on guard, and all the palace servants, - in short, everyone having any duties at the palace or in any way attending the court, - besides all the diplomats of foreign countries accredited to Madrid, and their wives and all the members of their staffs and their wives, must dress in mourning. Notices are sent to the Diplomatic Corps by the Introducer of Ambassadors, saying:

"By reason of the death of His Royal Highness, Prince — of - His Majesty the King (whom God guard) has seen fit to order — days of mourning, beginning on the - day of - O. Of these days, shall be rigorous mourning; — shall be light mourning." 
Forthwith diplomats and their wives must dress accordingly. During the rigorous mourning, only black can be worn; in the period of half-mourning, mauve, gray, or white. You may be starting out for a dinner, or perhaps for the opera, or even to attend a ball. You receive your notice. It is not necessary that you cancel your engagement. Court mourning does not require that. It merely exacts that you change your clothes. Still, I have heard men declare that it is inconvenient, and I have heard wives of diplomats assert that black was not becoming to them, but that, nevertheless, with members of royal families dying in all parts of the world, they had been obliged during one year to dress in deep mourning more than half the time-which was indeed true. I confess that a dinner of twenty or thirty people with half of the ladies dressed in black - and such I have often attended-does not seem very jolly. Of course, if death has come into the royal family of the country to which one is accredited, sincere sorrow and sympathy find their natural expression in a suspension of gay functions.

The period of mourning is regulated by fixed tables, which are applied as mechanically as a banker applies his interest tables. There is, first, the table applicable when the deceased is a member of the royal family of Spain or of a foreign family related to it. It starts with the King, for whom six months of mourning is prescribed: four rigorous, and two light. However, when Alfonso XII died, a year's mourning was decreed: six months rigorous, six months light. 
306 THE COURT OF HIS CATHOLIC MAJESTY

For the heir apparent the period is six months: three rigorous, three light. For any other son of the King, three months, and so on down the line, diminishing as the relationship to the King becomes more remote, until we get to second cousins who have not been declared infantes. For those we mourn fourteen days: half rigorous, half light. Table II, printed and displayed on a card in the Mayordomia Mayor and in the Ministry of State, prescribes the mourning when the deceased is a member of a royal family not related to that of Spain. For an emperor or a king the period is twenty-four days: half rigorous, half light; for an heir to the throne, twenty days; for other sons of kings, fourteen days, and so decreasing as relationship to the sovereign of the foreign country becomes remoter. Then we have a third table, with still shorter periods of mourning for the families of those lesser potentates, grand-dukes, and electors whom His Majesty (the King of Spain) addresses as "brothers," and finally a fourth table, with still shorter periods for the families of dukes and other sovereign princes whom His Majesty (the King of Spain) addresses as "cousins." If the deceased be a cousin of a duke of this last class we put on our mourning in Spain for only four days: two rigorous, two light. In these instances the time has very likely expired when the notice is received by us.

If the deceased was a sovereign, his successor communicates the news of the death to the other rulers of the world and announces his own succession; in the same letter he usually either 
confirms the powers of the Ambassador or Minister Plenipotentiary who had been appointed by his predecessor, or he names another person to replace him; for, according to strict rule, the powers of a diplomatic representative of a monarch end with the death of the sovereign who accredited him, or with the death of the sovereign to whom he was accredited. Autograph letters of sympathy are despatched by all the rulers of the world to the heir and successor of the deceased monarch, and it is quite customary to send special representatives to the funeral. It is also the custom for the new. sovereign, after that, to send special ambassadors to the courts of all other monarchs, to express his appreciation of their messages of sympathy and to make a formal official announcement of his accession to the throne.

Many times during my residence in Madrid I attended, in my diplomatic capacity, state funerals, decreed by the King in honor of men, not members of the royal family, who had rendered illustrious services to the nation. Chief among them were those of Señor Silvela and Señor Villaverde, two former Prime Ministers. To them were given funerals with all the military honors which are accorded to a captain general in command. The processions on these occasions were imposing pageants. I recall vividly the impression made upon me by the grand cortège which accompanied the body of Señor Silvela through the streets of the capital. Thousands who were representative of all that was most illustrious in politics, war, letters, society, science, and art had gathered 
in front of his residence. One room of the house had been transformed into a capilla ardiente, where, in the presence of as many as could crowd in, masses for the repose of the soul of the deceased were said. The casket was carried out of the house and placed upon an open hearse without glass at the sides or ends. The hearse was drawn by six black horses covered with heavy black pall, which was so long that it almost dragged on the ground. On their heads were gilt metal crowns, in which were long black plumes.

Troops lined the route. At the head of the procession was a mounted detachment of that carefully selected and splendidly disciplined body, the Guardia Civil. A battery of artillery and a battalion of infantry followed. Then came a seemingly interminable double line of inmates of the orphan asylums and of all the other similar charitable institutions, in charge of nuns and priests. After them appeared at least a score of church societies, fraternities, and sororities, nearly every parish in Madrid being represented. Then the funeral carriage or hearse passed. Close to it, on each side, marched six halberdiers; while farther away from it, but still at the sides of it, walked very many nuns of various orders and the concierges and porters of the Prime Minister's office, of the House of Deputies, and of the various ministries and royal academies of learning to which the deceased had belonged. All these were carrying large lighted candles. From the casket black ribbons extended in all directions. Those most closely associated with the deceased in his various 
fields of lifework held these ribbons and walked close to the hearse. Among them were Señor Maura, representing the former Prime Ministers; Señor Moret, afterwards Prime Minister, representing the Academy of Jurisprudence, and the Count of Casa Valencia, former Ambassador to the court of St. James, representing the Royal Spanish Academy. Of both of these academies Señor Silvela had been president. Others who held ribbons were fellow members of the deceased in the Academy of History, the Academy of Moral and Political Sciences, and the Academy of Fine Arts. Still other ribbons were held by the captain general, as representative of the army; by an admiral, as representative of the navy; by General Azcarraga, also a former Prime Minister, as the representative of the Knights Grand Cross of Carlos III, and by the Marquis of Santa Maria de Silvela, as Vice-President of Congress. Nephews of the deceased, and other relatives, walked behind the hearse, and immediately after them came a full company of the Royal Halberdiers, with their famous band, and the mounted Escolta Real, with cornetists and trumpeters.

Then on foot came the duelo (the grief) all those who followed the dead to his grave to show for him their respect and esteem and affection. Never do the women in Spain appear in these processions. The duelo is usually headed by persons related to the deceased, but not by the most closely related. At state funerals the representatives of the King and of the other members of the royal family, the representatives 
3IO THE COURT OF HIS CATHOLIC MAJESTY

of the Government, and those members of the family of the deceased who attend, walk in the first line. At the funeral of Señor Silvela the duelo was headed by the personal representatives of the King and of the other members of the royal family; the Prime Minister and the other Ministers of the Crown, in full uniform; the Nuncio of the Pope and two of the bishops, in their purple robes; the Presidents of the Senate and the House of Deputies; three relatives of the deceased, and the executors of his will. After them came the provincial deputation and the City Council, preceded by its mace-bearers. Foreign ambassadors and Ministers Plenipotentiary followed. More than a score of ex-Ministers of the Crown walked next in line. In that group one saw Salmeron, one of the presidents of Spain's short-lived republic of $1873-74$; the Duke of Veragua, the last lineal descendant of Columbus; General Weyler, one time commander of Spain's forces in Cuba; Lopez Dominguez and Montero Rios, both of whom were afterwards to become Prime Ministers. Behind these walked many hundreds of Spain's representative men. Then there was a long file of empty carriages, that of the family of the deceased being completely covered with crêpe. Some of the carriages belonged to those who were walking in the procession, and would be used by them on the return from the cemetery. Others were sent by persons who could not attend the funeral, as a sign of respect; for such is the custom in Spain.

In the blazing heat of that day, May 31, 1905, this procession made its way from the house of 
the deceased to the extreme opposite side of Madrid. Everyone, except the mounted troops, went on foot. When the procession arrived at the captain general's headquarters, near the Royal Palace, the hearse was drawn up at the side of the street. The committee which presided over the duelo stationed itself near it, and then the troops, which had lined the way and had fallen in behind the others, marched by, saluting as they passed the hearse, while their bands played the March of the Dead. It had been arranged that the formal cortège should be disbanded here rather than at the cemetery, a mile or more out of the city, in the country. Therefore the great majority of those who had been in the procession passed in line before the committee which headed the duelo, shook hands with them, according to Spanish custom, expressed to them their sympathy, and then took leave. Many persons, however, continued as far as the grave, and most of the carriages followed the hearse, whether their owners went or not. The line of carriages reached almost from the palace to the cemetery. There, while the body was being put in its last resting-place, a section of the Guardia Civil, a battery of artillery and a detachment of infantry fired salutes over it.

Just a week later, at the church of San Francisco el Grande, took place what the Spaniards call los funerales (the mass for the repose of the soul of the dead) of Señor Silvela, whose burial I have just described. It, too, was a state service. The King and the members of the royal family were again represented by various nobles. 
These, with others who presided over the duelo on the day of the burial, sat at the side of the catafalque which had been erected just in front of the chancel, and when they arrived at the church, as well as when they left it, military honors were rendered to them by a company of infantry which had been sent to the church for the purpose. In a square near by was stationed a battery of artillery, which fired salutes when the mass commenced, when the Host was elevated, and when the service was finished. The Ministers of the Crown were all present in uniform. The Diplomatic Corps, also in uniform, sat on one side of the catafalque. In the body of the church were seen nearly all the delegations and committees, as well as the majority of the individuals who, a week before, had followed the dead on his way to the cemetery. The Cardinal Archbishop officiated in the mass and two bishops assisted. The service was choral and was magnificently sung.

The day before this requiem mass for Señor Silvela I was in this same church, with all my diplomatic colleagues and nearly all the official world, to attend the special and solemn Te Deum service that was sung in thanksgiving because of King Alfonso's escape from assassination a week before (May 3I, I905), when a bomb was thrown at him and President Loubet, whom he was visiting, in the streets of Paris. Many were wounded by that bomb, but the King and the President both escaped without any injury whatever. Less than three years later I went to this same church for the funerales, the requiem mass, for His 
Majesty King Carlos of Portugal and his young son, the heir apparent, who had been assassinated in the streets of Lisbon a few days earlier (February I, 1908). King Alfonso attended this service in person, coming expressly for it from Seville, where he was spending part of the Winter. Great fears for his safety were felt, for anarchy was rampant in Spain, and it was thought that a veritable epidemic of lawlessness might break out as a result of the Lisbon outrage. The route from the palace to the church was lined with soldiers standing so close to each other that it seemed as if no one could wedge his way between them. Fear had kept many who ought to have attended that service from doing so. As I looked around from my seat in the section reserved for the Diplomatic Corps, third from the King, who was seated in the chancel, I noticed that the church was not more than half full. That afternoon when I arrived home I learned that during the service detectives had arrested an anarchist at the door of the church. He had endeavored to enter dressed as a priest. On his person was found a loaded revolver. Just such an attempt, in this very disguise, had been thought possible, and the parish clergy had guarded against it by agreeing that a certain word of a certain verse of the Gospel for the day should be required as a pass word of every priest and acolyte and choir-boy entering the church. The anarchist could not give it. 


\section{CHAPTER XVIII}

\section{The Court and Madrid Society}

$7 \mathrm{HE}$ etiquette of the Spanish court has long been universally regarded as the most I rigid and frigid, the most formal and formidable, in Europe. There has, doubtless, been much exaggeration in what has been written upon this subject; but, in large measure, until quite recent years the popular belief has been well founded. Whether or not in these respects the court of Madrid really surpassed, in ancient days, the sister court of the Habsburgs at Vienna or that of Louis the Great in France, it is certain that from the reign of the Emperor Charles the Fifth (King Charles I of Spain), at the beginning of the sixteenth century, to the time of Charles III, in the middle of the eighteenth, and to some extent down to the close of the Napoleonic wars, an etiquette existed at the Court of His Catholic Majesty which, although formulated for the purpose of practically deifying the kings, actually resulted in making them, at first slaves, and later the victims of a gloomy melancholia.

Every word and act of the subject in the presence of the sovereign, as well as everything affecting the conduct of the monarch in his relations with others, were regulated and controlled by 
strict rules. They bore, perhaps, more heavily upon the sovereign than upon the subject. Such simple operations as those of going to bed were attended by so much formality and ceremony that the effort to retire for rest was harder than a whole day's toil. Every article of apparel that was taken off, and the night robe that was put on, had to be passed from hand to hand along a long line of chamberlains and gentlemen in waiting, grandees of Spain, who vied with each other for the honor of assisting in this important state service, and each of whom had his specific and definitely prescribed duty, which he jealously regarded as his special prerogative. There were rules governing everything pertaining to the court, - the dress to be worn, the coiffure permitted, the attitudes and poses to be adopted, the phrases and expressions to be used, the gestures to be made, the writings to be employed. There were rules as to the time when things must be done, the place where they might be done, the persons by whom or in whose presence they were to be done. And for every rank and class and category of society, and for every variety of circumstance, the rules differed.

The theory of the sanctity of the sovereign's person was carried to almost as absurd a degree as in China to-day. No one could touch the person of the queen under penalty of death. Once, when one of the queens was thrown from the saddle by a runaway horse and was being dragged along the ground by it in danger of instant and horrible death, the two gentlemen who after some 
hesitation dared to run out and catch the horse and extricate the queen, and thus save her life, did not dare to remain any longer at the court, but immediately and precipitately fled from Madrid. The death of Philip III is attributed by serious historians to etiquette. That monarch was sick, and his illness was plainly being aggravated one day by the intense heat or the gas given off by the charcoal brazier that was burning in his room. One of the King's entourage asked the Duke of Alba, gentleman in waiting, to take away the brazier to afford the King relief, but the Duke replied that etiquette assigned that honorable duty, not to him, but to the lord chamberlain. So someone went to look for the lord chamberlain, but before he arrived the King was seized with an acute attack, from which he soon died.

In creating for their subjects the strict court etiquette, the Spanish monarchs brought into being, like Frankenstein, a monster who was afterwards to destroy them. They shut out the sunshine of the presence of others and pined away in the dungeons of their own loneliness. They were surrounded with throngs of obsequious flatterers, yet their lives were solitary. Their whole life was one of ennui. Day followed day with monotony and dull routine. Rising and dressing were irksome, ceremonious tasks. After that came mass, where they sat behind an iron grill, screened off from the rest of the world. When they drove through the streets, the curtains of their carriages were drawn. When they presided over the councils of Ministers, it was in silence. 
At the audiences which they granted there was very little said, although bows and reverences were plentiful; and rules determined the exact number of steps which one must take to the right, and the exact number to the left. The duties for every day of the year and for every hour of the day were all prescribed by the protocol, and the minutest details were regulated. A life more narrow and restricted could hardly be imagined. There was no freedom, no scope for the exercise of the initiative, nothing to develop and stimulate the King's powers and faculties; on the contrary, there was everything to dwarf them and to cause decay. No wonder that Philip IV was weak and vacillating; that the feeble intellectual powers of Charles II became atrophied, and that Philip V sank into profound melancholia.

To a great extent the evil system lasted until Napoleon brought about the abdication of both Charles IV and Ferdinand VII. After the expulsion of the French and the restoration of the latter king, the old etiquette was never fully reëstablished. Ferdinand had lost too much power and prestige to be able to maintain a splendid court. He could not decree an etiquette that would make the greatest of his nobles prostrate themselves before him, and perhaps he realized that were he able to do so he would be forging chains of solitary slavery for himself. So the old rules were less and less strictly enforced under him. His daughter, Isabella II, was essentially openhearted and fond of company, and she chafed at restraint. Under her, court etiquette became less 
3 I8 THE COURT OF HIS CATHOLIC MAJESTY

formal. Furthermore, the spirit of democracy was gathering strength, and it was steadily, although silently, waging warfare with many practices that it considered obsequious. Constitutional guarantees were conferring upon the subject greater political rights and were increasing his importance, his influence, and his independence.

Alfonso XII, by natural temperament as well as by the training of experience, was affable, approachable, companionable. He had an inquiring mind and was always eager to meet those from whom he could obtain information. Moreover, his dynasty was in no sense firmly established. In being conciliatory in his political methods and cordial in his relations with his people, he was not only acting in accord with his true character, but was pursuing a course favorable to his own interests. The present king, Alfonso XIII, along with many noble traits from his mother, inherits the qualities which gave to his father his charm of manner and his hold upon the affections of the people. On formal occasions of state ceremony he is every inch a king, quite conscious apparently of his proud lineage, which leads him back on one side of his family to Louis the Great of France and to Henry IV, Henry of Navarre, and on the other to the great Empress Maria Theresa and to the long line of Habsburgs who were emperors of the Holy Roman Empire. Let him lead his troops in review, and no one rides his horse better, sits more firm in the saddle, or appears more soldier-like. Let him attend some great service in church or cathedral, seated in the 
great chair of state in the chancel, no one is more punctilious in the observance of the ritual. Let him take his place upon the throne on a day of one of the great receptions, when thousands of his subjects file before him, there is no relaxation of court etiquette. Let him open the Cortes and, from the high platform where sit the presidents and officers of the two co-legislative bodies, read; in loud voice, the speech from the throne, it is a king who speaks.

Without undue sacrifice of dignity, Alfonso XIII has, however, done much to emancipate himself from the shackles that used to keep the Spanish sovereigns from social intercourse with their subjects. Under him the etiquette of the court may be considered as having reached a rational basis. Traditions and customs still exercise a powerful influence, but the subject need no longer be an obsequious flatterer, and the monarch no longer stands aloof from his subjects. To-day the Court of His Catholic Majesty is in some respects more democratic than many other European courts. There is very much truth in the statements made by a modern Spanish journalist, who has written as follows:

"Almost all the points, of etiquette observed at present by the persons who have access to the King and the Queen and the members of their family are merely formulas of pure courtesy, with which those who are aware of them comply.... Taking the glove off the right hand, in order to shake hands with the King if he extends his hand; treating him with the respect due his high position, rising when he rises, and not speaking to him except in reply to his questions, - these are the chief points to be observed." 
It may be added that except at first and formal audiences, the King and Queen aim, by their questions, to lead up to subjects of mutual interest, upon which the person to whom the audience is accorded is allowed to converse with reasonable freedom and fulness. The private audiences accorded, at least those to diplomats, are far from being mere catechisings. Furthermore, it may be added that to foreigners who are presented to Their Majesties more leniency in matters of etiquette is shown. More strict compliance is required from the subject, and most strict of all from the courtier. For omissions and neglect to observe the rules the latter is blamable; whereas the stranger, because of ignorance, may be excusable.

The life of the royal family has thus broadened, and the change has profoundly affected the society of Madrid. Diplomats who were colleagues of mine in the years when $I$ was at that court (1905-1909), and who had been there a long time, were continually telling me of the great changes that were taking place in these four years, - how different and how much better it all was than it used to be. The change was due principally to the King's own independence of conviction, his fondness for society, his affability, and his eagerness to learn. Undoubtedly he was much influenced by what he saw in England. It is fair to believe that he took the late King Edward as his mentor in many matters, and endeavored to follow his political methods and to adopt his habit of frequent visits to his subjects and of 
acceptance of invitations to their houses for dinners, balls, and other social functions. The young Queen Victoria, accustomed to the free life of the English royal family, of course encouraged this tendency, and apparently all the Spanish royal family enjoyed the new rule; for in the final years of my residence in Madrid they were almost every week during the social season either at one of the Embassies or at the houses of some of the great Spanish families. And they were not only the "honor guests" and the honored guests, but when the entertainment was of a nature permitting it, they participated in it and added greatly to the pleasure. The King danced in cotillions and favored the ladies, like any other gallant cavalier. I remember once seeing him in a sort of forfeit figure when four couples led out, and after dancing for a time, the four ladies were placed at one end of the room, while the four men who were their partners chose four other men, and the eight sat down on the floor and, sliding, endeavored to make their way across the room, the winners gaining the privilege of continuing the dance with the four ladies. The Infanta Isabella always put life and "go" into the parties which she attended and danced until the "wee short hours." The Queen and the Infanta Maria Theresa danced in all the quadrilles, and the Queen Mother was always an interested spectator.

The entertainments which the members of the royal family attended were varied in their character. How well I recall the splendid balls in the 
palace of the great Dowager Duchess of Bailen, and the beautiful fancy-dress ball, when the stately minuet was danced, in the house of that indefatigable entertainer, the Marquesa Squilache! She maintained a salon which, in the number and character of those who weekly gathered at her home, reminded one of the salons of the great ladies of France who, in the sixteenth and seventeenth centuries, exercised so potent an influence upon the life and politics of that country. How well I recall, too, the brilliant musicale which the Duke of Alba gave in his palace of Liria, when the famous Italian tenor, Anselmi, sang and all the royal family were present! And there comes to mind that other occasion which they honored with their presence, when Madame Iturbe, widow of the former Mexican Minister to Madrid, gave a grand entertainment, in which scores of young people helped to commemorate the centenary of the Spanish War of Independence of France, which began in 1808 . These young people dressed so as to represent the great historic characters of that stirring epoch, and participated in a parade which filed through the very spacious rooms of Madame Iturbe's palace and passed in review before the King. Not a few in that procession were lineally descended from those whose roles they took, and there was therefore vital interest in this panorama of the past, in which the portraits painted by Goya and the other great painters of the time moved before us in actual life. The balls at the palace of Cervellon, given by the Duchess of Fernan Nuñez, recalled 
the splendor of ancient days. The Duchess of Pinohermoso, as a compliment to the sovereigns, arranged an entertainment of a character dear to the literature-loving Spaniards, at which the cleverest and brightest of modern poets and playwrights read selections from their unpublished works and recited sonnets expressly composed in honor of the King and Queen.

But of all the Spanish families, the one which was entertaining the most frequently, and the one where members of the royal family were most of ten seen, was that of Casa Valencia, the head of which was the former. Ambassador of Spain at London, his wife being the sister-in-law of the great Prime Minister, the late Señor Cánovas del Castillo. There were many young people in this family, all of exceptional attainments and of great vivacity of temperament. Here the King, the Queen, the other members of the royal family, the Diplomatic Corps, and all of Madrid society were frequent guests, - now at a musicale, now at a fancy-dress party, and repeatedly at amateur theatricals, representations of those sparkling comedies with which Spanish literature in all ages has abounded. The leading parts were taken by the Marquesa Quiros, the Viscount Ponton, Señorita Maria Alcala Galiano, Juan Alcala Galiano, and Alvaro Alcala Galiano, the talented sons and daughters of the house.

Nearly every Embassy, in 1907 and 1908, entertained the King and Queen at dinner. On these occasions Their Majesties were accompanied by the Lord Chamberlain, the Grand Mistress of 
324 THE COURT OF HIS CATHOLIC MAJESTY the Robes, and others of their suites; and the list of guests, which, of course, was previously submitted to the King, contained few, if any, names except those of Spaniards and the personnel of the Embassy in which the dinner was given.

Diplomatic dinners tendered by the foreign representatives in honor of those who were high in Government or court circles, but at which no member of the royal family was present, were of course given with great frequency; and although it is true that the Spaniards were more often guests than hosts, there was in 1907, 1908, and 1909 a much increased tendency on their part to invite the diplomats to their houses. I have grateful recollections of hospitalities constantly extended to me; and one of my colleagues, an ambassador who had been at Madrid ten years and who was always persona grata to the society of the capital, told me he had received more invitations from Spanish families in I908 than in the previous nine years. The wife of Señor Allendesalazar, Minister of State, was constantly entertaining the Diplomatic Corps in their home and the Minister himself at times banqueted the entire corps in the rooms of the ministry.

Conflicting claims as to precedence had long been a stumbling-block to inviting Spaniards and diplomats to the same functions. There was always special trouble about the claims and pretensions of Ministers Plenipotentiary, ambassadors, and grandees. The place that one occupies at a table becomes a most important matter at a diplomatic dinner. Not everyone has the sense 


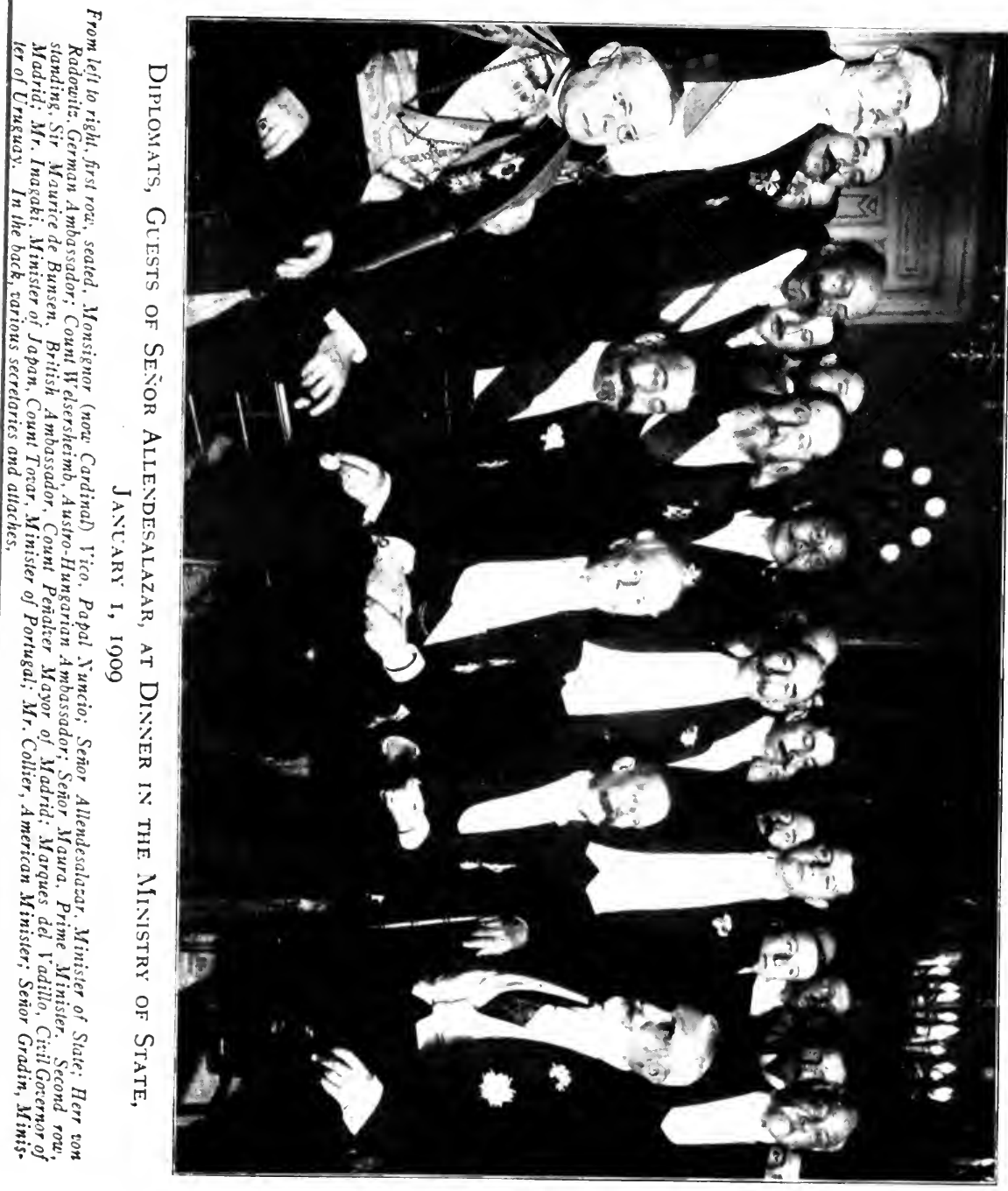




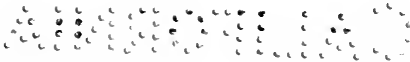


of self-esteem that led the chief of the Scottish clan to say: "Where the MacGregor sits, that is the head of the table." Just before my arrival at Madrid, the Ambassador of one of the great powers was reported as having left a colleague's table because he was not given his proper seat; and it is a fact that at another dinner a certain Knight of the Order of the Golden Fleece, seeing that he was placed fourth at the table, - a seat which he deemed inferior to that which should have been given him, - somewhat dramatically removed the insignia of this illustrious order from his neck and put them in his pocket, remarking audibly as he did so: "Señor Don Juan Fulano [himself] can with pleasure occupy the fourth seat at this table, but a Knight of the Golden Fleece, never!"

This disposition to dispute about precedence, seemingly so petty, is not, as is sometimes thought, a special weakness of Spanish character. It exists and has existed wherever differences of rank are recognized, in the hierarchy of the church as well as in the nobility of the world. Is it not historic that, in the Middle Ages, the English archbishops of York and Canterbury, at one of the church councils, quarrelled over the question who should preside, and each fighting for the chair, the contest ended by one sitting in the lap of the other? Each of these prelates strove to obtain from the Pope recognition as Primate. The Pope was shrewd. He gave to the Archbishop of York the title which he still enjoys to-day, "Primate of England," and then he made 
326 THE COURT OF HIS CATHOLIC MAJESTY the Archbishop of Canterbury "Primate of All England.'

The difficulties as to precedence in Spain sprang in large part from the fact that the relative ranks of grandees, cardinals, ambassadors, Knights of the Golden Fleece, the head of the Government, and the Lord Chamberlain were not, and even to-day are not, defined with exactness. Special trouble is often found in reconciling the claims of grandees, of whom there are more than two hundred, with the others; for grandees claim to be cousins of the King. The trouble occurs most frequently at dinners. For years the solution was not to invite them and the others to the same dinner, or to give no dinners at all. But matters are gradually adjusting themselves at Madrid. True, the host who wishes to avoid difficulties endeavors to select as his guests those whose claims do not clash, but with an increasing spirit of concession and reciprocity, and by the submission of all doubtful questions to the Introducer of Ambassadors, whose duty it is to decide them for the foreign diplomats, friction is avoided, and the members of the Diplomatic Corps more and more entertain and are entertained by the Spanish grandees.

One will have an incomplete idea of the King of Spain if he sees him only in great ceremonies or even at afternoon or evening social functions. To know him at his best, in his relations with others, it is necessary to have audiences with him or to witness his participation in some of the many forms of sport in which he takes interest. I had 
the good fortune to secure private audiences with him for several distinguished Americans, although, of course, it was a favor which I asked only when I felt that there was a just claim to it because of real eminence. The King always accorded my fellow countrymen a cordial reception, always showed interest in America and friendliness for it, always endeavored to gain some information about it and its institutions. I have told in other chapters one or two of the incidents connected with some of these presentations. I recall with pleasure the hearty reception given by him to my friend, the late General William F. Draper, formerly American Ambassador to Italy, whom I presented to the King in 1907. The King said to him: "I believe you are not Ambassador now." "No, Señor," said General Draper, raising the index finger with that characteristic gesture which to all his friends was the sure sign that something witty was coming, "No, Señor, I am only an ex-ambassador, and Your Majesty knows that ex in politics, like $x$ in algebra, is an unknown quantity." How the King laughed at the joke! and then how quickly the conversation glided into more serious topics, - all the more quickly as Mrs. Draper's father, General Preston, had been American Minister to Spain in the years just prior to the American Civil War. Reference was made to the fact, and subjects of conversation were suggested by it.

Several times a year, accompanied by Mrs. Collier, I had a private audience with the King and the Queen. The etiquette requires that a diplomat should ask for such audiences before 
328 THE COURT OF HIS CATHOLIC MAJESTY

taking any long journey out of the country, and also after his return. These were, perhaps, the best occasions afforded me to know the sovereigns, in a certain sense intimately, to converse with them at length, to learn something of their interests and tastes, and to form an estimate of their abilities. Without flattery, I can say that I always came away impressed by the King's wide general knowledge and the extent of his information about current events. He had the latest news and understood it in all its relations with other events and in its bearing upon Spanish policies and interests. This was, doubtless, due to the résumé and explanations made by the Prime Minister at the weekly councils over which the King presides. I do not mean to convey the idea that the King was a profound thinker or an intellectual prodigy, that he was as great a statesman as his Prime Minister, or as great a soldier as his best captain general, or that he knew everything or anything as well as or better than anyone else. I mean simply that he knew very much of very many subjects; that he possessed a quick intelligence, a broad education, and a very inquiring mind. The Queen always impressed me as a woman of much more than usual intellectual ability.

Frankness compels me to say that there were people in Spain who criticised the King's devotion to outdoor sports. There were many in and around the court who spent their time in worrying lest he would be crushed in an automobile accident or would fall off his yacht and be drowned. My 
own idea was that he showed very good sense in his persistent efforts to overcome any possible constitutional or hereditary weakness by outdoor exercise, and that his physical development into a tall, active, alert young man, capable of enduring fatigue, quick in thinking, ready in acting, and devoid of the sense of physical fear, was a complete justification of his course. From earliest childhood the King was an exceptionally good horseman, and in youth he became a splendid shot. I have told, in other chapters, of his fondness for hunting and shooting. When I went to Madrid, in 1905, automobiling was his passion. People thought that he took great risks and was reckless, but no accident occurred. I think that he did not develop more than a Platonic love for golf. Tennis interested him, but less than other sports. In 1905, when he went to England for his state visit to King Edward, it was arranged by the British Government that he should cross over from Cherbourg to Southampton on the British royal yacht. This was a six-hours' cross-channel journey, and as in those days the King declared that he was seasick not only when on the sea, but also after landing, great efforts were made by him to have the route changed so that he could cross from Calais to Dover, a voyage of one hour or less. But the programme was not altered. Whether or not the dreaded mal de mer affected him on this occasion I do not know, but from the time of his return he became passionately fond of yachting and did all that he could to encourage the sport. He travelled much in his steam yacht the Giralda, and he had a large 
330 THE COURT OF HIS CATHOLIC MAJESTY number of small yachts of the "knock-about" type or "sonderklasse" built. He learned how to sail them and was a contestant in nearly every regatta at San Sebastian, Bilbao, and Santander, on the coast of the Bay of Biscay, and later at Alicante on the Mediterranean. When he was at San Sebastian he was on the water much of the time. In recent years he has developed a great liking for polo; at Madrid and at La Granja he gives up a great deal of time to this sport, having had fine polo fields laid out and contesting teams organized. Some of his most loyal subjects complain of his participation in this exciting and dangerous game, but let those who so zealously cry "Long live the King!" remember that life is hardly worth living if there be not the mens sana in corpore sano. 


RETURN TO the circulation desk of any, University of California Library or to the NORTHERN REGIONAL LIBRARY FACILITY Bldg. 400, Richmond Field Station University of California Richmond, CA 94804-4698

ALL BOOKS MAY BE RECALLED AFTER 7 DAYS - 2-month loans may be renewed by calling (510) 642-6753

- 1-year loans may be recharged by bringing books to NRLF

- Renewals and recharges may be made 4 days prior to due date.

DUE AS STAMPED BELOW

\section{SEP 142001}




$$
\begin{aligned}
& 247053 \\
& D P \\
& 238 \\
& C 6
\end{aligned}
$$

THE UNIVERSITY OF CALIFORNIA LIBRARY 


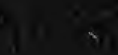

